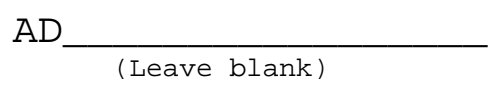

Award Number:

W81XWH-04-1-0818

\title{
TITLE :
}

Castration Induced Neuroendocrine Mediated Progression of Prostate Cancer

PRINCIPAL INVESTIGATOR:

Christopher P. Evans, M.D.

CONTRACTING ORGANIZATION:

University of California, Davis

Sacramento, CA 95817

REPORT DATE: September 2008

TYPE OF REPORT:

Final Addendum

PREPARED FOR: U.S. Army Medical Research and Materiel Command Fort Detrick, Maryland 21702-5012

\section{DISTRIBUTION STATEMENT: (Check one)}

X Approved for public release; distribution unlimited

Distribution limited to U.S. Government agencies only; report contains proprietary information

The views, opinions and/or findings contained in this report are those of the author(s) and should not be construed as an official Department of the Army position, policy or decision unless so designated by other documentation. 


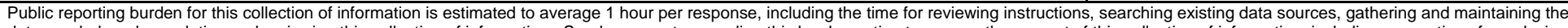

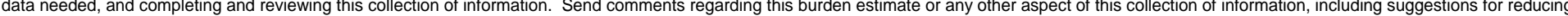

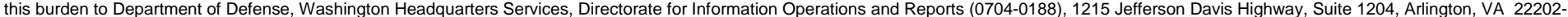

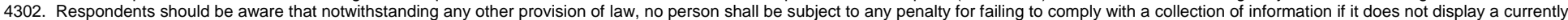
valid OMB control number. PLEASE DO NOT RETURN YOUR FORM TO THE ABOVE ADDRESS.

\begin{tabular}{l|l|l}
\hline 1. REPORT DATE (DD-MM-YYYY) & 2. REPORT TYPE & 3. DATES COVERED (FrOm - TO)
\end{tabular}

$30 / 09 / 08 \quad$ Final Addendum

4. TITLE AND SUBTITLE

Castration Induced Neuroendocrine Mediated Progression of Prostate Cancer

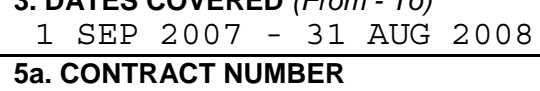

$-$

5b. GRANT NUMBER

W81XWH- $04-1-0818$

5c. PROGRAM ELEMENT NUMBER

\section{AUTHOR(S)}

Christopher P. Evans, M.D.

Email: cpevans@ucdavis.edu

\section{PERFORMING ORGANIZATION NAME(S) AND ADDRESS(ES)}

University of California, Davis Department of Urology 4860 Y Street, Suite 3500 Sacramento, CA 95817

\section{SPONSORING I MONITORING AGENCY NAME(S) AND ADDRESS(ES)}

United States Army Medical

Research and Material Command

\section{DISTRIBUTION / AVAILABILITY STATEMENT}

Approved for Public Release 5d. PROJECT NUMBER

5e. TASK NUMBER

$-$

5f. WORK UNIT NUMBER

$-$

8. PERFORMING ORGANIZATION REPORT NUMBER

10. SPONSOR/MONITOR'S ACRONYM(S) $-$

11. SPONSOR/MONITOR'S REPORT NUMBER(S)

\section{SUPPLEMENTARY NOTES}

$-$

\section{ABSTRACT}

We explored the relationship between androgen withdrawal as an event that initiates a cascade promoting the development of androgen-independent prostate cancer through neuroendocrine progression. We define the early post-castration molecular events and linked androgendeprivation therapy to the activation of non-receptor tyrosine kinases that promote androgenindependent growth and migration. We developed an animal model to validate this hypothesis that metastasize in SCID mice. We found that deregulation through non-receptor tyrosine kinases was blocked by Src-specific inhibitor AZD0530. We found this inhibited 100\% of metastasis in an animal model. The translational benefit of this study was that through a National Cancer Institute sponsored trial, the drug is being tested for hormone refractory prostate cancer.

\section{SUBJECT TERMS}

Prostate Cancer, Neuroendocrine, Progression, Androgen-Independence

\begin{tabular}{|c|c|c|c|c|c|}
\hline $\begin{array}{l}\text { 16. SECURI } \\
U\end{array}$ & IFICATION OF: & & $\begin{array}{l}\text { 17. LIMITATION } \\
\text { OF ABSTRACT }\end{array}$ & $\begin{array}{l}\text { 18. NUMBER } \\
\text { OF PAGES }\end{array}$ & $\begin{array}{l}\text { 19a. NAME OF RESPONSIBLE PERSON } \\
\text { Christopher P. Evans, MD }\end{array}$ \\
\hline $\begin{array}{l}\text { a. REPORT } \\
\text { U }\end{array}$ & $\begin{array}{l}\text { b. ABSTRACT } \\
U\end{array}$ & $\begin{array}{l}\text { c. THIS PAGE } \\
\mathrm{U}\end{array}$ & UU & 107 & $\begin{array}{l}\text { 19b. TELEPHONE NUMBER (include area } \\
\text { code) } \\
916-734-5154\end{array}$ \\
\hline
\end{tabular}




\section{Table of Contents}

Page

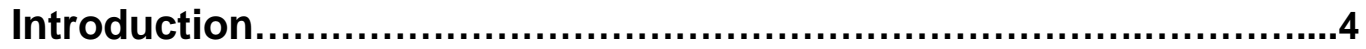

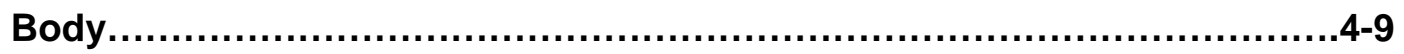

Key Research Accomplishments........................................

Reportable Outcomes......................................................... 10

Conclusions................................................................14

References.......................................................................14

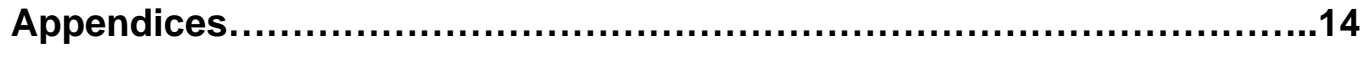


DOD Final Progress Report 2008

\section{Introduction}

We believe that androgen withdrawal is an event that initiates a cascade promoting the development of androgen independence through NE progression. To date we know of no adjuvant therapies targeting castration initiated molecular events in clinical practice. As such, we seek to better define these early post-castration molecular events. We hypothesize that a small population of neuropeptide expressing AI CaP cells generated by castration can support the AI survival and growth of androgen sensitive cells in a paracrine fashion. This concept is a novel one regarding the early propagation of $\mathrm{CaP}$ following castration. Secondly, we hypothesize that neuropeptide mediated nonreceptor tyrosine-kinase signaling activates androgen regulated genes both through AR and GRP dependent, and AR and GRP independent mechanisms. Demonstration of this concept establishes the rationale for neuropeptide pathway inhibition as singular and combination therapy at the time of castration.

\section{Body}

Aim 1. To determine the paracrine effect of NE cells on androgen sensitive CaP cells. a. Determine the in vitro ability for NE cells to support androgen sensitive CaP cell survival and growth (paracrine effect) in androgen-deprived conditions. Work on this section was replaced by the soft agar assay as results in soft agar are more definitive.

b. Determine the paracrine effect in soft agar tumorgenesis. LNCaP-Zeo cells (green) do not form colonies when plated in androgen deprived soft-agar. Colony formation of LNCaP-Zeo cells (green) in soft agar assay was promoted when plated chimerically with LNCaP-GRP cells (red) (bottom left). Due to the paracrine effect of GRP expression from the GRP cells, the androgen sensitive Zeo cells formed twenty-four fold more colonies in androgen-deprived soft agar compared to when growing alone. This stimulation may be partially inhibited by a battery of Src kinase inhibitors, PP2, AZM475271, and AZD0530 (bottom right).
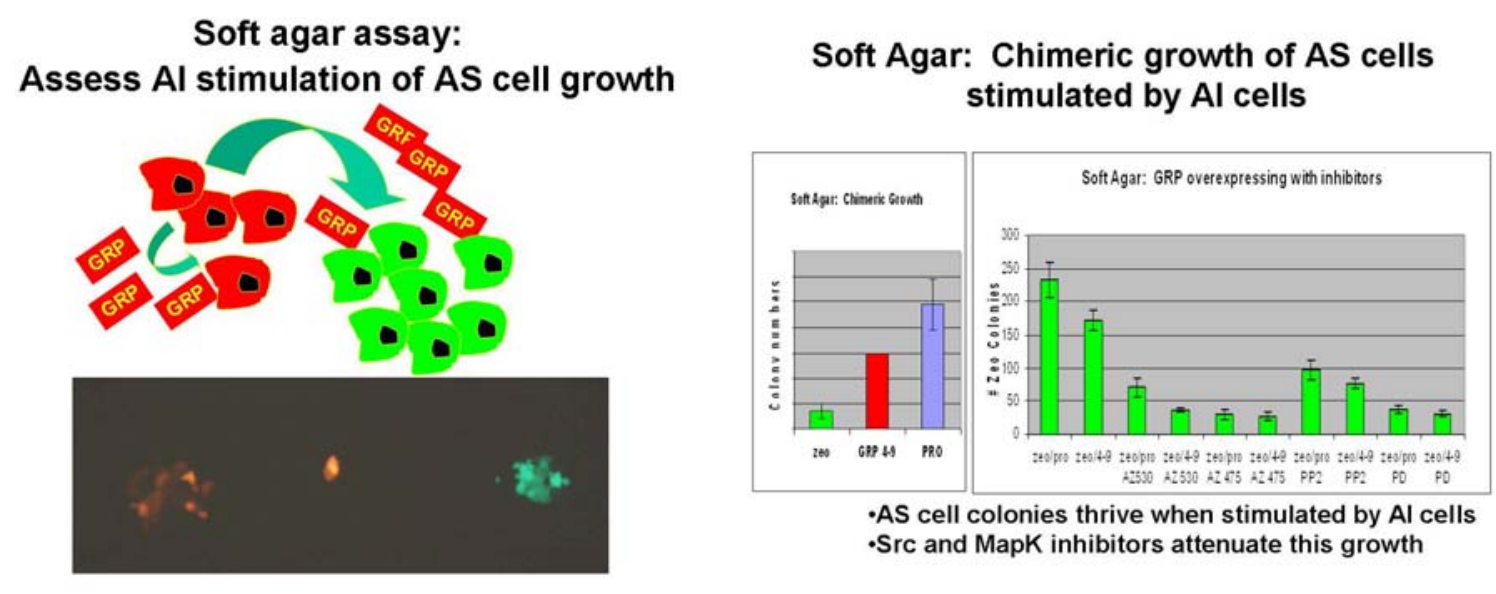

c. Determine the paracrine effect on migration in recombinant NE cells. Stimulation of migration of LNCaP-Zeo cells by GRP cells was assessed by scratch 
migration assay. This assay was conducted with the help of fluorescence tags and microscopes. LNCaP-Zeo cells do not migrate in an unstimulated environment to any significant degree. LNCaP-Zeo-GFP migrated 1.7 fold more to the scratch region when plated together with LNCaP-GRP-Red cells than alone (bottom left). MEK1 inhibitor, PD98059 and Src kinase inhibitors, AZM475271 and AZD0530 all partially inhibited this stimulated migration of LNCaP-Zeo-GFP cells (bottom right).

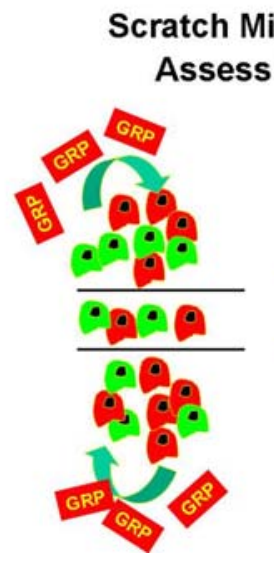

\section{Scratch Migration: Chimeric stimulation of AS cells to migrate}
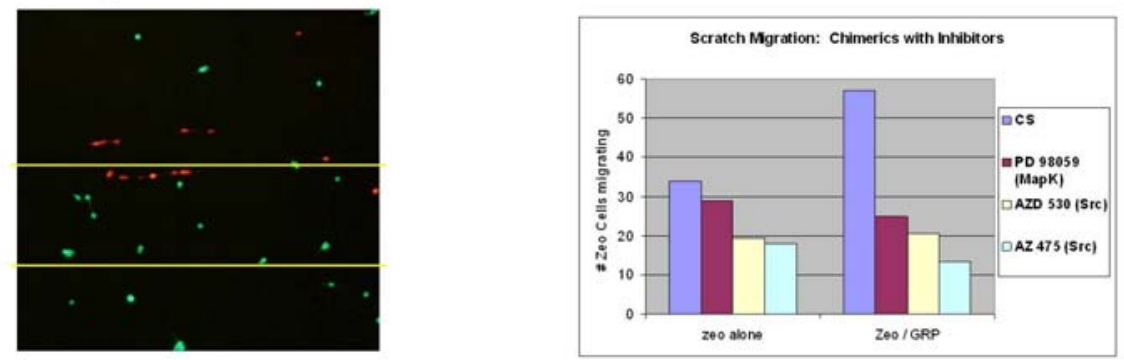

-GRP Al cells promoted migration of AS cells into lanes -Src and MAPK inhibitors significantly reduced migration

d. Study the paracrine effect using the in vivo xenograft model with regard to growth and metastasis. Co-injection of LNCaP-Zeo cells with LNCaP-GRP cells in castrated SCID mice produced tumors in the prostate regions. LNCaP-Zeo cells are not normally

\section{Growth of LNCaP supported in Al conditions by LNCaP-GRP}

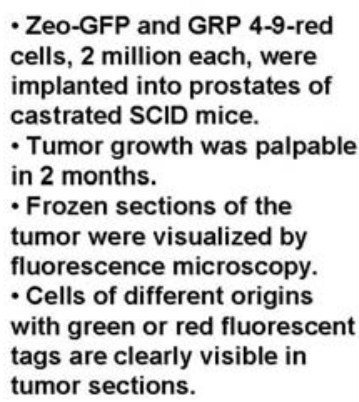

- Zeo-GFP and GRP 4-9-red cells, 2 million each, were implanted into prostates of castrated SCID mice.

- Tumor growth was palpable in 2 months.

- Frozen sections of the tumor were visualized by fluorescence microscopy. - Cells of different origins with green or red fluorescent tags are clearly visible in tumor sections. tumorigenic in the in vivo castrate environment. The Zeo cells were tagged with green fluorescence protein (GFP) and the GRP with red (Red). Frozen sections of tumor vividly showed patches of green and red colors under the fluorescent microscope. Taken together, both overexpression of GRP may stimulate growth of androgen sensitive Zeo cells both in vitro and in vivo through paracrine effect. 
Aim 2. To evaluate the mechanisms of AR involvement in our NE model. a. Testing of inhibition of neuropeptides, signaling molecules and AR inhibitors individually and in combination on soft agar growth of GRP clones and xenograft cells. Tumors harvested from GRP implanted

NE CaP Tumors in Castrated SCID Mice

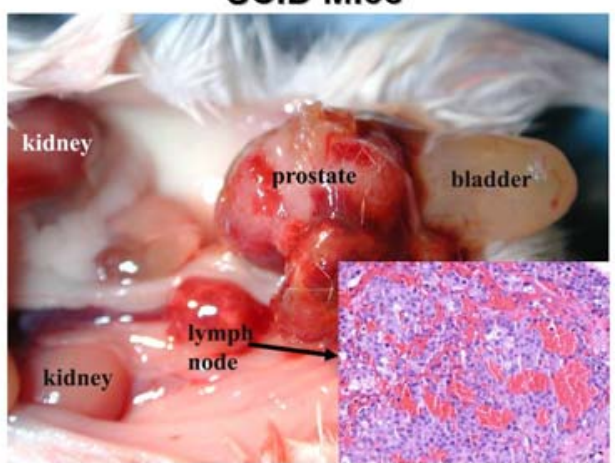

Inhibition of Recultured Xenografts

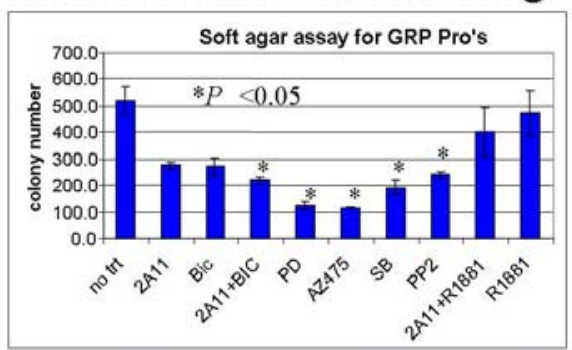

Soft agar assay of the recultured GRP Pro's xenograft. Treatments include: monoclonal antibody to bombesin/GRP, 2 A11 (1 mg/ml), anti-androgen bicalutamide (BIC, $5 \mu \mathrm{M}$ ), MEK1 inhibitor PD98059 (PD, $10 \mu \mathrm{M})$,

Src inhibitors AZM457271 (5 $\mu \mathrm{M})$ and PP2 $(10 \mu \mathrm{M})$,

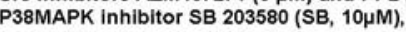
synthetic androgen R1881 ( $1 \mu \mathrm{M})$.

mice were re-cultured in vitro to establish xenografts termed as GRP-Pro (derived from Prostate). The expression of human AR, PSA and GRP in tumor xenograft GRP-Pro was analyzed by RT-PCR analysis and supports the authenticity of the clones. Soft agar assay using GRP-Pro showed their aggressive nature as manifested by their androgen- and anchorage- independent growth in 2 weeks. This growth was partially inhibited by the $\mathrm{mAb}$ specific to bombesin, $2 \mathrm{~A} 11$, the androgen inhibitor, bicalutamide, and in combinations (with significant difference $p \leq 0.05$ ) supporting that the growth is dependent on both the neuropeptide GRP and AR. When synthetic androgen was added with 2A11, the colony formation ability of GRP-Pro resumed to a level similar to control. This further supports the overlapping effect of GRP and AR to the growth of GRP-Pro. Based on the tyrosine kinase display, Src kinase is present in LNCaP cells and involved in signaling via phosphorylation upon bombesin stimulation. Src kinase was constitutively active in LNCaP GRP and its xenograft GRP-Pro when cultured in androgen-free CS serum media. We thus subjected growth of LNCaP GRP-Pro to the inhibitors for Src kinases, AZM475271 from AstraZeneca and PP2. Since MEK1/2 is downstream to Src activation, we also tested the effect of PD98059. Finally, we included the MAPK P38K inhibitor SB203580 because P38 displayed activation in LNCaP cells upon androgen withdrawal. All kinase inhibitors tested decreased the growth $60-80 \%$ of control, with significant differences $(p \leq 0.05)$. This suggests that the androgenindependent growth of GRP-Pro involves both Src and MEK in a GRP stimulated ARdependent manner.

The mechanisms of neuropeptide-mediated AR activation were then investigated in more detail. We performed chromatin immunoprecipitation (ChIP) assay and discovered that bombesin-stimulated AR binds preferentially to the proximal ARE site in the promoter region rather than the enhancer region bound by the androgen-stimulated AR. GRP-Pro cells constitutively expressing GRP have the AR occupied on the proximal ARE constantly. This bombesin/GRP-stimulated preferential binding of AR to the proximal site of the PSA promoter is assisted by the AR co-activator ACTR 30 min from addition of bombesin. 

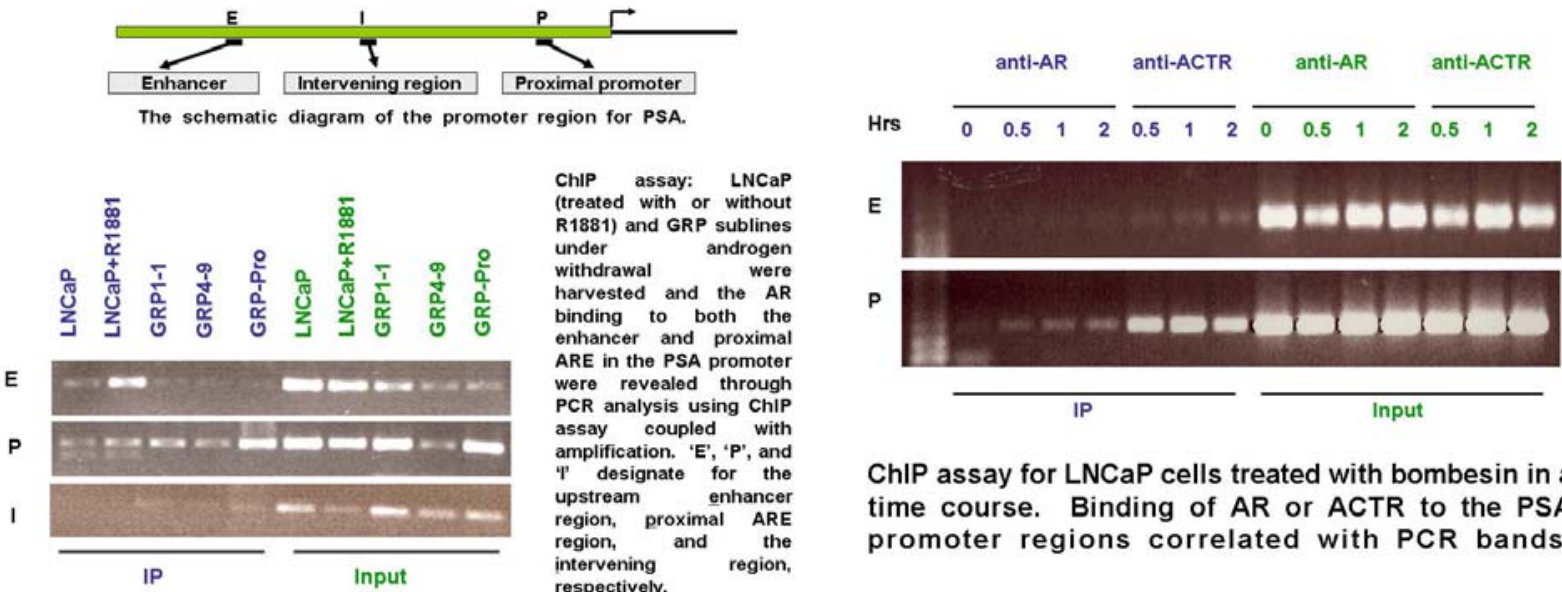

ChIP assay for LNCaP cells treated with bombesin in a time course. Binding of AR or ACTR to the PSA promoter regions correlated with PCR bands.

As reported last year, growth of GRP cells in soft agar may be inhibited by the specific Src inhibitor AZD0530. We performed a dose-response growth inhibition curve using GRP-Pro cells grown in CS media and treated with various doses of AZD0530. The IC50 for this inhibition is slightly higher than $1 \mu \mathrm{M}$. The LNCaP GRP cell lines have demonstrated promoted migratory activities than their parental cells. Src kinase inhibitor AZD0530 inhibits the migration assayed by the Boyden chamber assay to the levels similar to the basal activity in the LNCaP cells.

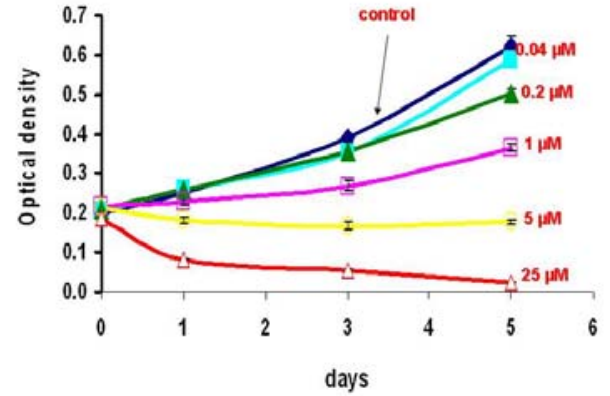

GRP-Pro cells were plated in CS medium with and without the Src inhibitor AZD0530 and their growth was monitored by MTT assay over 7 days. Various concentrations of AZD0530 from 0.04 to $25 \mu \mathrm{M}$ were added from day 0 . Error bars represented standard error of means.

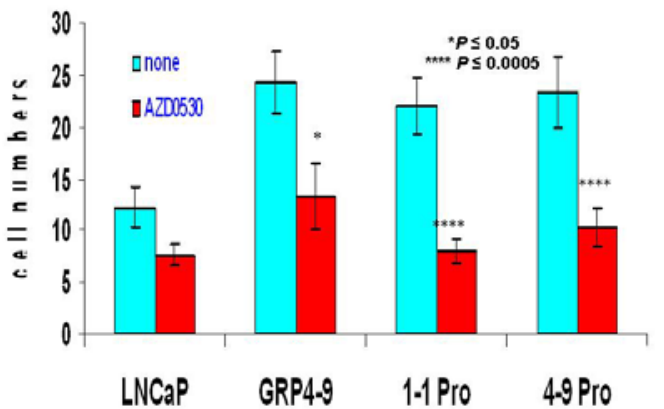

Inhibition of migration of LNCaP-GRP and GRP-Pro cells by AZD0530. Migration assays were carried out in the modified Boyden chamber. Migration assays were performed in a Boyden chamber with $8 \mathrm{~mm}$ Nucleopore membrane coated with human plasma fibronectin $(50 \mathrm{mg} / \mathrm{ml}) .2 \times 10^{4} \mathrm{LNCaP}$ cells were placed in the upper wells, CS conditioned media with or without $500 \mathrm{nM}$ AZD0530 in the lower wells, and the chamber was incubated at $37^{\circ} \mathrm{C}$ for 4 hours to allow cell migration. The entire field was counted under a microscope and each experiment was performed in triplicate. 


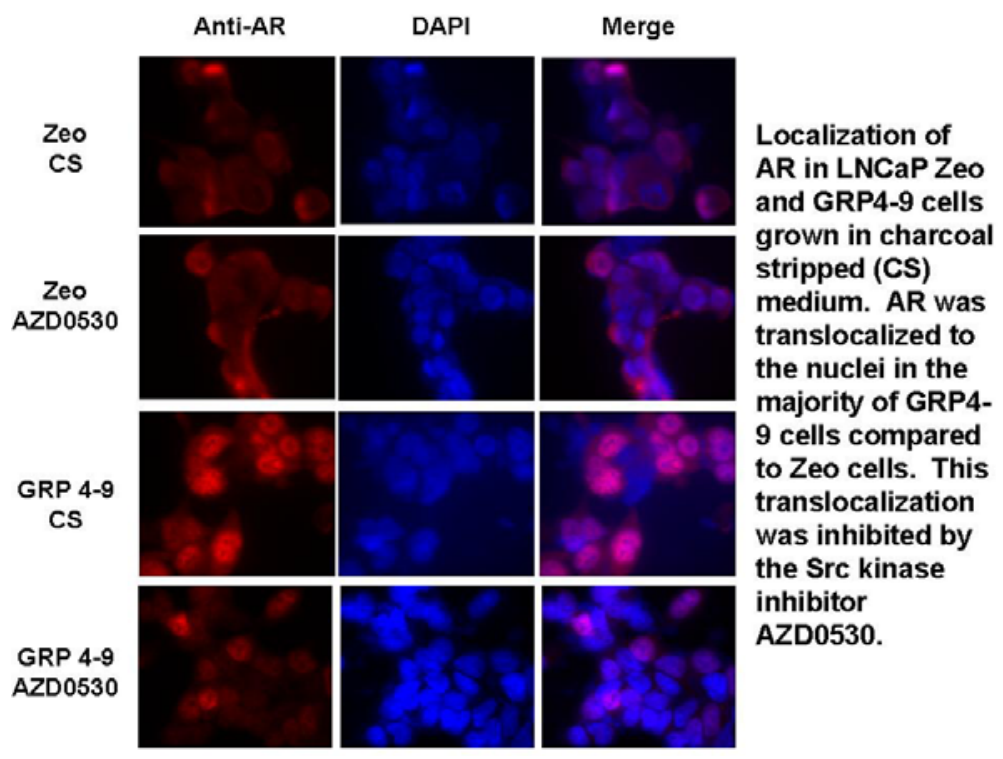

LNCaP GRP cells showed translocalization of AR into the nuclei in the absence of androgen stimulation (in CS growth media) compared to the mocktransfected LNCaP Zeo cells. Addition of $\mathrm{Src}$ kinase inhibitor AZD0530 abolished the AR nuclear translocalization as shown in the left. This result suggests that $\mathrm{AR}$ is activated through autocrine stimulation of GRP that is dependent of Src activation.

We surveyed the status

of Src and FAK in the LNCaP and GRP subclones and found similar levels of phosporylated Src and FAK kinases. However, when these two kinases were coimmunoprecipitated by anti-FAK antibodies, stronger phospho-Src levels were detected in GRP subclones than their mock control Zeo cells. These findings confirm our hypothesis that in the absence of AR, bombesin/GRP bind to their receptors, activate Src and FAK kinases in the complex and activate AR through phosphorylation.

b. Small hairpin RNA (shRNA)-based silencing of NE cells in vitro and in vivo. We are in the process of designing the shRNA. Once we get the shRNA construct, we will start experiments in this section. We have requested the no-cost one-year extension to

Src and FAK status in cell lysates

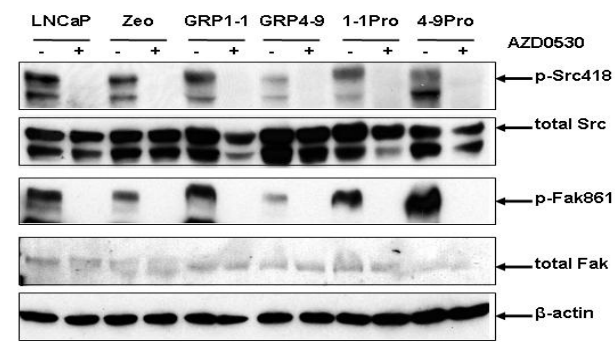

Phosphorylation of Src and FAK kinases was inhibited in parental LNCaP, LNCaP-GRP and GRP-Pro cells by AZD0530 as probed by antibodies specific to $\operatorname{Tyr}(418)-S r c$ and $\operatorname{Tyr}(861)-F A K$, respectively. The ability of AZD0530 to inhibit Src-mediated phosphorylation of FAK kinase was explained by co-immunoprecipitation (cO-IP) of FAK and Src kinases with anti-FAK antibody. complete this and the in vivo study.

c. Testing of inhibitory treatments on chimeric tumors in soft agar and in vivo. We have demonstrated inhibition of paracrine migration. We are presently testing inhibition of chimeric tumor growth and metastasis in vivo. 
d. In vivo testing of inhibitory treatments at different time points. Since we have identified Src kinase as the key player in neuropeptide-mediated AR activation, we tested the effect of Src kinase inhibitor AZD0530 in vivo with LNCaP GRPPro cells. After almost two months of AZD0530 administration to castrated mice injected with LNCaP GRP-Pro cells, we observed a complete inhibition of metastasis by AZD0530. Although inhibition of primary tumor growth was not significant as reported by other researchers working on various cancers, AZD0530 demonstrated potent inhibition on tumor metastasis. None of the treated animals had metastases to regional

In vivo study: Ten male SCID mice were castrated and orthotopically implanted with $4 \times 10^{6}$ GRP-Pro cells into the prostate. AZD0530 (50 $\mathrm{mg} / \mathrm{kg}$ ) treatment was administrated to seven mice (treatment group) while buffer was administrated to three (control group) 16 days after surgery. The study was terminated $\mathbf{7 0}$ days after injection, mice from both groups were examined for primary tumor growth and metastasis. At the end of study, two remaining control mice both bore tumors and metastasis to lymph nodes, while five out of seven treated mice produced tumors but with NO metastasis.

\begin{tabular}{|l|ccc|}
\hline & Tumor & $\begin{array}{c}\text { Tumor } \\
\text { weight (g) }\end{array}$ & Metastasis \\
\hline Control & $\begin{array}{c}3 / 3 \text { (one died before } \\
\text { tumor collection) }\end{array}$ & $1.04 \pm 0.34$ & $2 / 2$ \\
Treatment & $5 / 7$ & $0.73 \pm 0.29$ & $0 / 5$ \\
\hline
\end{tabular}
lymph nodes but both surviving control animals did. The PSA, tumor weight and metastasis data are summarized in the control and treated animals below.
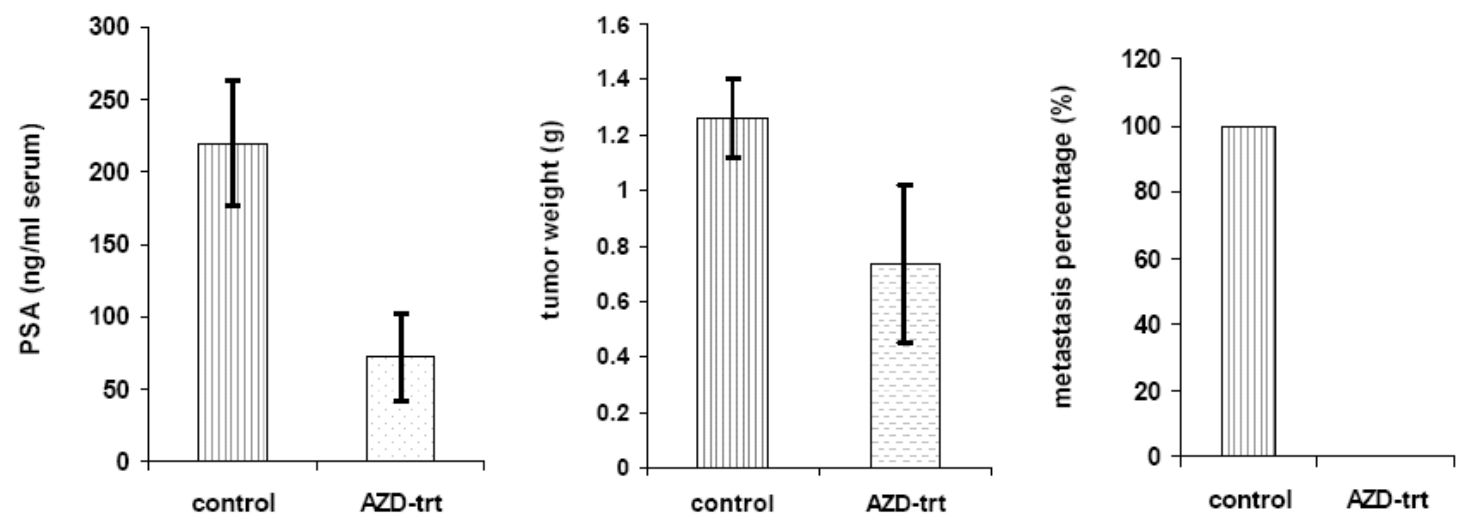

\section{Other Research Accomplishments}

We have characterized the expression of the NE induced expression of src, FAK and STAT3 in all major prostate cancer cell lines. We have also validated the action of Src kinase inhibitor AZD0530 through the Src signaling pathway in two androgenindependent prostate cancer cell lines PC-3 and DU-145 by examining the status of phosphorylation of the downstream kinases and substrates. Through this study, we have identified the molecular mechanism of AZD0530. In vivo inhibitions of tumor progression by AZD0530 are also underway. These data were recently published in Oncogene (Aug 4, 2008, epub).

We have determined the downstream signaling cascades from NE activation and delineated the effect of a novel oral src kinase inhibitor AZD0530 at these signaling points. This data is under revised review for publication in Cancer Research.

\section{Key Research Accomplishments}

We have demonstrated that Src kinase is the key player in neuropeptide-mediated AR activation. Together with our studies in the chimeric growth of androgen-sensitive 
and androgen-insensitive cells, we are more confident with our proposed hypothesis. A paracrine effect exists for androgen insensitive $\mathrm{CaP}$ cells to support the survival and proliferation and migration of androgen sensitive $\mathrm{CaP}$ cells in a castrated environment. We have further delineated the impact of NE differentiation in prostate cancer. Most importantly, the NCI CTEP has selected AZD0530 for clinical trials, to include AICaP and based upon the above data, we were awarded this trial. Also, another Phase II AZD0530 international trial is underway in patients with prostate and breast cancer with bone metastases.

\section{Reportable Outcomes}

Abstract presentations 2004-2005

1. 2004 Yang, J.C., Busby, J.E., Kung, HJ, Evans, C.P. Potent antiproliferative effects of Src kinase inhibition in a model of neuropeptide-induced androgen-independent prostate cancer. European Journal of Cancer 2(8) p.121, No. 405. (NCI/AACR/EORTC joint Molecular Therapeutics in Cancer meeting, Geneva, Switzerland).

2. 2005 Yang, J.C., Busby, J.E., Kung, HJ, Evans, C.P. Src inhibition of neuropeptideinduced androgen-independent prostate cancer. Proceedings of the American Association for Cancer Research, 46: p.748, No. 3180.

3. 2005 Evans, C.P., Busby, J.E., Kung, HJ, Yang, J.C. Androgen-sensitive prostate cancer survival and progression is supported by neuroendocrine prostate cancer cells. Proceedings of the American Association for Cancer Research, 46: p.1033, No. 4369.

4. 2005 Yang, J.C., Busby, J.E., Kung, HJ, Evans, C.P. Src kinase inhibition of neuropeptide-induced androgen-independent prostate cancer. Proceedings of the American Urological Association, 173: p.127, No. 464.

\section{Publications 2004-2005}

1. 2004 Busby, J.E., Evans, C.P. Determining variables for repeat prostate biopsy - A review. Prostate Cancer and Prostatic Diseases, 7:93-8.

2. 2004 Penson, D.F., Moul, J.W., Evans, C.P., Doyle, J.J., Gandhi, S., Stern, L, Lamerato, L. The economic burden of metastatic and prostate specific antigen progression in patients with prostate cancer: findings from a retrospective analysis of health plan data. J. Urol., 171:2250-2254.

3. 2004 Evans, C.P. Evidence-based medicine for the urologist. BJU Int., 94:1-2.

4. 2004 Busby, J. E. and Evans, C.P. Old friends, new ways: revisiting extended lymphadenectomy and neoadjuvant chemotherapy to improve outcomes. Curr Opin Urol 14:251-257.

5. 2005 Sam S. Chang, Mitchell C. Benson, Steve Campbell, Juanita Crook, Robert Dreicer, Christopher P. Evans, M. Craig Hall, Celestia Higano, W. Kevin Kelly, Oliver Sartor and Joseph A. Smith, Jr. SOCIETY OF UROLOGIC ONCOLOGY POSITION STATEMENT: REDEFINING THE MANAGEMENT OF HORMONE-REFRACTORY PROSTATE CARCINOMA. Cancer 2005;103:11-21.

6. 2005 Evans, C.P., Fleshner, N., Fitzpatrick, J. and Zlotta, A. An evidence based approach to understanding pharmacological class effect in the management of prostatic diseases. BJU Int. 2005;95:743-749.

8. 2005 Ok, J., Meyers, F. J., Evans, C.P. Medical and surgical palliative care of patients with urological malignancies. J. Urol. 174:1177-1182. 
9. 2005 Ok, J., Cambio, A., Lara, P.N., Evans, C.P. Is the use of anything but MVAC justified in the evidence-based medicine era? Curr. Opinion Urol., 15:312-314.

\section{Abstract presentations 2006}

1. 2006 Chang, Y-M., Bai, L., Yang, J.C., Kung, H-J., and Evans, C.P. Survey of Src activity and Src-related growth and migration in prostate cancer lines. Proceedings of the American Association for Cancer Research, 47: 2505.

2. 2006 Yang, J.C., Bai, L., Kung, H-J., and Evans, C.P. Androgen-sensitive prostate cancer survival and progression is supported by neuroendocrine prostate cancer cells. Proceedings of the American Urological Association, 175:409.

3. 2006 Evans, C.P., Bai, L., Kung, H-J., and Yang, J.C. Androgen-sensitive prostate cancer survival and progression is supported by neuroendocrine prostate cancer cells. Urological Research Society, Salzburg Austria.

\section{Publications 2006}

1. 2006 McGahan, J. P, Mee R., K., Evans C.P., Ellison, L. Efficacy of Transhepatic Radiofrequency Ablation of Renal Cell Carcinoma. Am. J Radiology 2006;186:S311S315.

2. 2006 Cambio, A. J., Evans, C.P. Management Approaches to Small Renal Tumours. BJU Int. 97:456-60.

3. 2006 Cambio A.J. and Evans, C.P. Minimising postoperative incontinence following radical prostatectomy: considerations and evidence. Eur Urol; 50(5):903-13; discussion 913.

4. 2006 Evans, C.P. Editorial Comment on "Penis Conserving Treatment for T1 and T2 Penile Carcinoma: Clinical Implications of a Local Recurrence. Lont, A.P. et al. J. Urol 2006; 176:580.

5. 2006 Cambio AJ, Evans CP. Outcomes and quality of life issues in the pharmacological management of benign prostatic hyperplasia (BPH). Therapeutics and Clinical Risk Management. Therapeutics and Clinical Risk Management., 3(1):181-196, 2007.

\section{Abstract presentations 2007}

1. 2007 Chang, Y-M., Bai, L., Yang, J.C., Kung, H-J., Evans, C.P. AZD0530 is a novel SRC kinase inhibitor with anti-proliferation and anti-migration properties in prostate cancer. Proceedings of the American Urological Association, 177: p.176, No. 532. 2. 2007 Yang, J.C., Chang, Y-M., Bai, L., Kung, H-J., and Evans, C.P. Inhibition of neuropeptide-mediated prostate cancer progression by specific SRC kinase inhibitor AZD0530. Proceedings of the American Urological Association, 177: p.221, No. 659.

\section{Publications 2007}

1. 2007 Nelson, E.C., Cambio A.J., Yang, J.C., Ok, J., Lara, P.N., Evans CP. Clinical Implications of Neuroendocrine Differentiation in Prostate Cancer. Prostate Cancer and Prostatic Diseases. 2007;10:6-14.

2. 2007 Nelson, E.C., Evans C.P., Lara, P.N. Renal cell carcinoma: current status and emerging therapies. Cancer Treat Rev. 33:299-313. 
3. 2007 Chang, Y-M., Kung, H-J, Evans, C.P. Non-Receptor Tyrosine Kinases in Prostate Cancer. Neoplasia. 2007; 9:90-100

4. 2007 Nelson, E.C., Cambio A.J. Yang, J.C., Lara, P., and Evans, C.P. Biologic agents as adjunctive therapy for prostate cancer: a rationale for use with androgen deprivation. Nature Clinical Practice Urology;4:82-94.

5. 2007 Cambio AJ, Evans CP. Outcomes and quality of life issues in the pharmacological management of benign prostatic hyperplasia (BPH). Therapeutics and Clinical Risk Management. Therapeutics and Clinical Risk Management., 3(1):181-196. 6. 2007 Cambio A.J., Ellison L.M., Chamie, K., deVere White, R.W., and Evans, C.P. Cost-Benefit and outcome analysis: effect of prostate biopsy under-grading. Urology. 69:1152-6.

7. 2007 Nelson, E.C., Evans, C.P., Mack, P.Cl, deVere White, R.W., Lara, P. Inhibition of Akt pathways in the treatment of prostate cancer. Prostate Cancer Prostatic Diseases 2007, Prostate Cancer Prostatic Dis., 10(4):331-9.

8. 2007 Nelson EC, Evans CP, Pan CX, Lara PN. Prostate cancer and markers of bone metabolism: diagnostic, prognostic, and therapeutic implications. World J Urol. 2007 Aug;25(4):393-9. Epub 2007 Jun 12. Review.

9. 2007 Evans CP. Editorial Comment on: Long-Term Intravesical Adjuvant Chemotherapy Further Reduces Recurrence Rate Compared with Short-Term Intravesical Chemotherapy and Short-Term Therapy with Bacillus Calmette-Guerin (BCG) in Patients with Non-Muscle-Invasive Bladder Cancer. Eur Urol. epub.

10. 2007 Cambio A.J., Evans, C.P. and Kurzrock, E.A. A paradigm shift in the management of multicystic dysplastic kidney. BJU Int, in press.

11. 2007 Chee K.G., Longmate J., Quinn D.I., Chatta G., Pinski J., Twardowski P., Pan C-X, Cambio A., Evans C.P., Gandara D.R., and Lara P.N. The AKT Inhibitor Perifosine in Biochemically Recurrent Prostate Cancer: A Phase II California/Pittsburgh Cancer Consortium Trial. Clin Genitourinary Cancer. 7:433-7.

\section{Abstract presentations 2008}

1. 2008 Lanfang Bai, Joy C. Yang, Phillip C. Mack, Hsing-Jien Kung and Christopher P. Evans. Targeting Src and multiple receptor tyrosine kinases (RTKs) simultaneously resulted in synergistic inhibition of proliferation and superior reduction of migration of renal cancer cells. Proceedings of the American Association of Cancer Research, Journal of Urology, 179(4), 34-35.

2. 2008 Bai L, Yang J, Mack P, Kung H-J, Evans C. Targeting Src and multiple receptor tyrosine kinases (RTKs) simultaneously resulted in synergistic inhibition of proliferation and superior reduction of migration of renal cancer cells. Proceedings of the AACR Meeting Abstracts 2008;2008:4863

3. 2008 Joy C. Yang, Lanfang Bai, Hsing-Jien Kung and Christopher P. Evans. Effect of the Specific Src Kinase Inhibitor AZD0530 on Osteolytic Lesions in Prostate Cancer. Proceedings of the American Urological Association, The Journal of Urology 179(4), 391. 
4. Yang J, Bai L, Kung H-J, Evans C. Effect of the Src inhibitor AZD0530 on osteolytic lesions in prostate cancer. Proceedings of the AACR Meeting Abstracts 2008;2008:4984

5. 2008 Xu-Bao Shi, Lingru Xue, Joy Yang, Christopher P Evans, Ralph W deVere White, MIR-125b Induces Androgen-Independent Growth of Prostate Cancer Cells. Proceedings of the American Urological Association, The Journal of Urology 179(4), 186-187.

\section{Publications 2008}

1. 2008 Gautschi, O., Tepper, C.G., Purnell, P.R., Izumiyq, Y., Evans, C.P., Green, T.P., Desprex, P.Y., Lara, P.N., Gandara, D.R., Mack, P.C., Kung, H-J. Regulation of Id1 expression by Src in cancer: implications for targeting of the bone morphogenetic protein pathway. Cancer Res 2008;68:2250-8.

2. 2008 Ramirez, M.L., Nelson, E.C., Evans, C.P. Beyond prostate-specific antigen: alternate serum markers. Prostate Cancer Prostatic Diseases. 2008; epub.

3. 2008 Ramirez, M.L., Nelson, E.C., de Vere White, R.W., Lara, P.N., Evans, C.P. Current Applications for Prostate-Specific Antigen Doubling Time. Eur. Urol. 2008; epub

4. 2008 Nelson E.C., Rodriguez R.L., Dawson K., Galvez A.F., Evans C.P. The interaction of genetic polymorphisms with lifestyle factors: implications for the dietary prevention of prostate cancer. Nutr. Cancer 2008;60:301-12.

5. 2008 Evans C.P., Editorial comment on: Tumor Characteristics of Carriers and Noncarriers of the decode 8q24 Prostate Cancer Susceptibility Alleles. J Urol. 2008; 179:2202

6. 2008 Evans C.P., Editorial comment on: Barriers to the Practice of Evidence-Based Urology. J Urol. 2008;179:2350

7. 2008 Chang Y-M, Bai L, Yang J.C, Kung H-J, Evans C.P. Src Family Kinase Oncogenic Potential and Pathways in Prostate Cancer As Revealed By AZD0530. Oncogene, Aug 4 epub.

8. 2008 Kung H-J, Evans C.P. Oncogenic Activation of Androgen Receptor. Urologic Oncology, in press.

9. 2008 Joy C. Yang, Joon-ha Ok, J. Erik Busby, Alexander D. Borowsky, Hsing-Jien Kung, and Christopher P. Evans. A novel neuropeptide-autocrine model for androgeninsensitive prostate cancer: aberrant activation of androgen receptor and inhibition by AZD0530 ${ }^{1}$, Revisions submitted to Cancer Research

\section{List of Contributing Personnel}

Christopher P. Evans, M.D. - Principal Investigator

Alexander Tsodikov, Ph.D. - Biostatistician

Joy Yang, Ph.D. - Assistant Researcher

Yu-Ming Chang, - Graduate Student Researcher

Lanfang Bai - Research Specialist 


\section{Conclusions}

We have made headway into understanding the paracrine relationship between neuropeptide expressing, androgen-insensitive $\mathrm{CaP}$ cells and their ability to support the proliferation and migration of androgen sensitive $\mathrm{CaP}$ cells. Critically, we have identified src kinase as a molecule central to the process. We have been awarded a NIH CTEP phase II trial to study a novel, oral src kinase inhibitor AZD0530 in androgeninsensitive prostate cancer patients based upon our work. We also are involved in a Phase II trial to evaluate AZD0530 in prostate and breast cancer patients with bone metastasis.

\section{References}

None

\section{List of Contributing Personnel}

Christopher P. Evans, M.D. - Principal Investigator

Alexander Tsodikov, Ph.D. - Biostatistician

Joy Yang, Ph.D. - Assistant Researcher

Yu-Ming Chang, - Graduate Student Researcher

Lanfang Bai - Research Specialist

\section{$\underline{\text { Appendices }}$ - See Attached}

1. Nelson EC, Cambio AJ, Yang JC, Ok JH, Lara PN Jr, Evans CP.

Clinical implications of neuroendocrine differentiation in prostate cancer.

Prostate Cancer Prostatic Dis. 2007;10(1):6-14.

2. Chang YM, Kung HJ, Evans CP.

Nonreceptor tyrosine kinases in prostate cancer.

Neoplasia. 2007 Feb;9(2):90-100.

3. Nelson EC, Cambio AJ, Yang JC, Lara PN Jr, Evans CP.

Biologic agents as adjunctive therapy for prostate cancer: a rationale for use with androgen deprivation.

Nat Clin Pract Urol. 2007 Feb;4(2):82-94.

4. Nelson EC, Evans CP, Mack PC, Devere-White RW, Lara PN Jr.

Inhibition of Akt pathways in the treatment of prostate cancer.

Prostate Cancer Prostatic Dis. 2007 May 1

5. Nelson EC, Evans CP, Pan CX, Lara PN Jr.

Prostate cancer and markers of bone metabolism: diagnostic, prognostic, and therapeutic implications.

World J Urol. 2007 Aug;25(4):393-9.

6. Chang YM, Bai L, Liu S, Yang JC, Kung HJ, Evans CP.

Src family kinase oncogenic potential and pathways in prostate cancer as revealed by AZD0530.

Oncogene. 2008 Aug 4, epub. 
7. Gautschi O, Tepper CG, Purnell PR, Izumiya Y, Evans CP, Green TP, Desprez PY, Lara PN, Gandara DR, Mack PC, Kung HJ.

Regulation of Id1 expression by SRC: implications for targeting of the bone morphogenetic protein pathway in cancer.

Cancer Research, 2008 Apr 1;68(7):2250-8

8. Joy C. Yang, Joon-ha Ok, J. Erik Busby, Alexander D. Borowsky, Hsing-Jien Kung, and Christopher P. Evans.

A novel neuropeptide-autocrine model for androgen-insensitive prostate cancer: aberrant activation of androgen receptor and inhibition by AZD0530 ${ }^{1}$,

Revisions submitted to Cancer Research, 2008 


\title{
Clinical implications of neuroendocrine differentiation in prostate cancer
}

\author{
EC Nelson, AJ Cambio, JC Yang, J-H Ok, PN Lara Jr and CP Evans \\ Department of Urology, Davis Medical Center, University of California at Davis, Sacramento, CA, USA
}

\begin{abstract}
The cellular signaling pathways of the prostate play a central role in the induction, maintenance, and progression of prostate cancer $(\mathrm{CaP})$. Neuroendocrine $(\mathrm{NE})$ cells demonstrate attributes that suggest they are an integral part of these signaling cascades. We summarize what is known regarding $\mathrm{NE}$ cells in $\mathrm{CaP}$ focusing on NE cellular transdifferentiation. This significant event in CaP progression appears to be accelerated by androgen deprivation (AD) treatment. We examine biochemical pathways that may impact NE differentiation in a chronological manner focusing on AD therapy (ADT) as a central event in inducing androgen-independent CaP. Our analysis is limited to the common adenocarcinoma pattern of CaP and excludes small-cell and carcinoid prostatic variants. In conclusion, we speculate on the future of treatment and research in this area. Prostate Cancer and Prostatic Diseases (2007) 10, 6-14. doi:10.1038/sj.pcan.4500922; published online 31 October 2006
\end{abstract}

Keywords: androgen-independent prostate cancer; hormone refractory; neuroendocrine cells; neuroendocrine differentiation

\section{Introduction}

Prostate cancer $(\mathrm{CaP})$ is the most common non-cutaneous malignancy in American men and is predicted to be the third leading cause of cancer deaths for 2006. ${ }^{1}$ Although local therapy for $\mathrm{CaP}$ is relatively effective, androgen deprivation therapy (ADT) remains the mainstay of treatment for disseminated disease and is principally palliative in nature. Introduced in the $1940 \mathrm{~s},{ }^{2}$ ADT removes androgen stimulation, initially inducing apoptosis in CaP. However, the disease eventually progresses to an androgen-independent (AI) state with an associated life expectancy of only 15-20 months. Despite continuous research efforts, limited progress has been made in the treatment of advanced $\mathrm{CaP}$ in the last 50 years and life expectancy associated with metastatic disease has not changed significantly. ${ }^{3}$ ADT, while extending length and quality of life for many patients, also induces biological changes in $\mathrm{CaP}$ that may promote progression to an AI state.

The role of prostatic neuroendocrine (NE) cells in this biologic process has recently become the focus of much attention. Known changes in the number, histology, and functions of $\mathrm{NE}$ cells during $\mathrm{CaP}$ progression indicate that they may play a regulatory role. The fact that the majority of NE cells may not exhibit androgen receptors (ARs) is of special interest in the androgen-deprived

Correspondence: Dr CP Evans, Department of Urology, Davis Medical Center, University of California at Davis, 4860 Y Street, Suite 3500, Sacramento, CA 95817, USA.

E-mail: christopher.evans@ucdmc.ucdavis.edu

Received 14 September 2006; accepted 2 October 2006; published online 31 October 2006 patient. $^{4,5}$ In these patients, NE cells may allow continued $\mathrm{CaP}$ growth through paracrine stimulation of neoplastic epithelial cells. Indeed, mitogenic and oncogenic activity has been demonstrated for many of the factors NE cells are known to produce.

The purpose of this review is to summarize the latest developments in understanding the role of NE cells in the normal prostate, in $\mathrm{CaP}$, and the effects on potential treatment modalities related to this. Data suggest that ADT may facilitate NE differentiation (NED) and thereby accelerate cellular mechanisms that contribute to the AI state. This review will be structured chronologically around this central event.

\section{NE histology and differentiation}

The normal prostate contains a glandular epithelium within intervening fibromuscular stroma. The epithelium can be further subdivided into tall columnar cells that secrete into the lumen of the gland, and cuboidal cells forming a basal layer against the basement membrane. A third type of epithelial cell was first described by Pretl in $1944 .{ }^{6}$ These cells are identified by their neurosecretory granules and expression of neuron peptide hormones such as bombesin/gastrin-releasing peptide (GRP), neurotensin (NT), serotonin, calcitonin and parathyroid hormone-related peptide (PTHrP). ${ }^{7,8}$ Based on these findings, they were labeled NE cells, part of the larger amine precursor uptake and decarboxylation (APUD) lineage.

In other organs, the origin of NE cells has been shown to be endodermal stem cells, ${ }^{9,10}$ and a similar model was 
thought to apply to prostatic NE cells. Bonkhoff et al. ${ }^{11}$ demonstrated a possible development progression for NE cells from stem cells using immunohistochemical staining to demonstrate intermediate phenotypes. Recently, neural crest cells have re-emerged as the putative source for NE cells. ${ }^{12}$ Although disagreement exists regarding the embryonic source of NE cells in the prostate, it is clear that prostatic epithelial cells are remarkably plastic and have the capability to differentiate into NE cells. As described below, the NE cells associated with $\mathrm{CaP}$ are phenotypically dissimilar to normal NE cells and function in different ways leading to the conclusion that they probably emerge from transdifferentiation of epithelial cells rather than malignant NE precursors.

\section{Normal function of NE cells}

Many secreted types of NE granules are identified by immunohistochemical staining and indicate that different subsets of NE cells exist. This introduces much complexity to the question of their normal function. A general understanding may be obtained by comparisons to NE cells in other organ systems and examination of the individual products secreted by prostatic NE cells.

Prostatic NE cells are part of a larger histological genre known as the APUD system, present in many organs of the body. For example, stomach D cells and G cells produce somatostatin and gastrin, respectively, and many intestinal NE cells secrete various hormones that regulate gut function. In a similar way, it may be inferred that the factors produced by prostatic NE cells regulate prostatic growth, function, and cellular differentiation. Indeed, many of the factors shown to be produced by NE cells are known to support growth and differentiation in the prostate (Table 1). For example, bombesin/GRP receptors are members of the superfamily of heterotrimeric G-protein-coupled transmembrane-spanning receptors. ${ }^{13}$ Binding of these receptors elicits calcium mobilization, thereby promoting growth and cell invasiveness through proteolytic activities in cell lines. ${ }^{14-17}$

If $\mathrm{NE}$ cells exert regulatory control over prostatic tissue, the question arises as to what regulates the NE cells. Although some NE cells may express $\mathrm{AR}_{1}{ }^{18}$ many are AI as they do not contain ARs. ${ }^{4,5}$ However, they do have receptors for epidermal growth factor (EGF) and ErbB2, which suggests they are controlled more by local growth factors from the prostatic stroma than systemic hormones. ${ }^{19}$ The expression of the EGF receptor itself is under the control of PTHrP produced by both epithelial cells and NE cells. It has been reported that interleukin
(IL) $-1 \beta$ and IL-6 upregulate CgA expression in CaP cell lines, ${ }^{20}$ and IL-6 has been shown to induce morphologic change toward an NE phenotype in epithelial cells. ${ }^{21}$

To summarize, NE cells express potent neuropeptides that mediate diverse biological processes such as cell growth, differentiation and transformation. In addition, their morphology and distribution within the prostate epithelium suggest a regulatory role similar to APUD cells in other organs of the body. In contrast to other epithelial cells, they are generally AR negative and probably rely on paracrine growth factor control.

\section{Role of NE cells in early CaP}

The NE cells in CaP appear morphologically different than those seen in benign tissue and co-express epithelial markers such as prostate-specific antigen (PSA) and NE markers $(\mathrm{CgA}){ }^{22,23}$ It is believed that these cells are the result of transdifferentiation of epithelial cells. ${ }^{24}$ Such NED has been experimentally demonstrated in several CaP cell lines using cyclic AMP (cAMP), epinephrine, forskolin, the cytokines IL-1 and IL-6, and as will be seen later, AD conditions. ${ }^{20,21,25,26}$ These changes were shown to be reversible when the substances were removed, ${ }^{27}$ emphasizing the incredible degree of plasticity exhibited by prostatic epithelial cells. Based on this likely mechanism for generating malignant NE cells, some NE cells may express neuropeptide growth factors before changing morphologically and/or expressing CgA, NSE, etc. In support of this, Iwamura et al. ${ }^{28}$ showed increased PTHrP in high-grade prostatic intraepithelial neoplasia before much NED had taken place as measured by common NE markers.

NED is very common in CaP specimens. For example, Bostwick et al. ${ }^{29}$ reported a prevalence of $92 \%$. Although wide ranges have been reported (30-100\%), this is probably due to different sampling techniques and testing methods. ${ }^{30}$ Several varieties of prostatic NED have been described. Two very rare types are small-cell carcinoma and carcinoid tumor, both of which express large numbers of malignant NE cells. The most common type is the typical adenocarcinoma with individual NE cells surrounded by small foci of epithelial CaP cells. This arrangement (Figure 1) suggests that the NE cells are producing growth factors supporting surrounding (proliferating) cells. ${ }^{31,32}$

The prognostic significance of NED is controversial. Many studies before 1990 showed a worse prognosis with increasing NED, but subsequent examinations failed to find any correlation independent of tumor

Table 1 Selected NE cellular products

\begin{tabular}{llc}
\hline Products & Action in CaP & References \\
\hline Calcitonin gene family & Growth modulation, in vitro resistance to apoptosis, stimulates PTHrP release \\
GRP & AI growth factor, mediates migration, in vitro resistance to apoptosis, activates NF- $\kappa \mathrm{B}$ & 45,66 \\
Neuropeptide $\mathrm{Y}$ & Possible angiogenic effect through MAP kinase & 96 \\
Parathyroid hormone-related protein & Mitogenic, regulates EGF receptor, overexpressed early in CaP & \\
Proadrenomedullin N-terminal peptide & Angiogenesis and GRP actions through GRP receptor binding & \\
Serotonin & Mitogen, facilitates AI growth & \\
VEGF & Angiogenesis, promotes growth and motility in AI manner & 28,98 \\
\hline
\end{tabular}

Abbreviations: AI, androgen-independent; $\mathrm{CaP}$, prostate cancer; GRP, gastrin-releasing peptide; MAP, mitogen-activated protein; NF- $\kappa \mathrm{B}$, nuclear factor-kappa B; PTHrP, parathyroid homone-related peptide; VEGF, vascular endothelial growth factor. 
grade or androgen responsiveness. ${ }^{7}$ The controversy continues with some recent studies showing an independent negative correlation between serum CgA and survival in $\mathrm{AI} \mathrm{CaP},{ }^{33,34}$ but others showing no prognostic correlation, ${ }^{35}$ or improved outcomes with higher $\mathrm{CgA} .{ }^{36}$ These authors all agree that the serum $\mathrm{CgA}$ continues to be a valid marker of progression, but the complex biology of NED makes direct correlation with prognosis difficult. Cussenot et al. ${ }^{37}$ studied CgA and NSE serum levels in $\mathrm{CaP}$ patients before ADT. Although most elevations of serum markers were found in AI tumors, some were not, leading them to theorize a role for NED in the progression of $\mathrm{CaP}$ before AD. Their

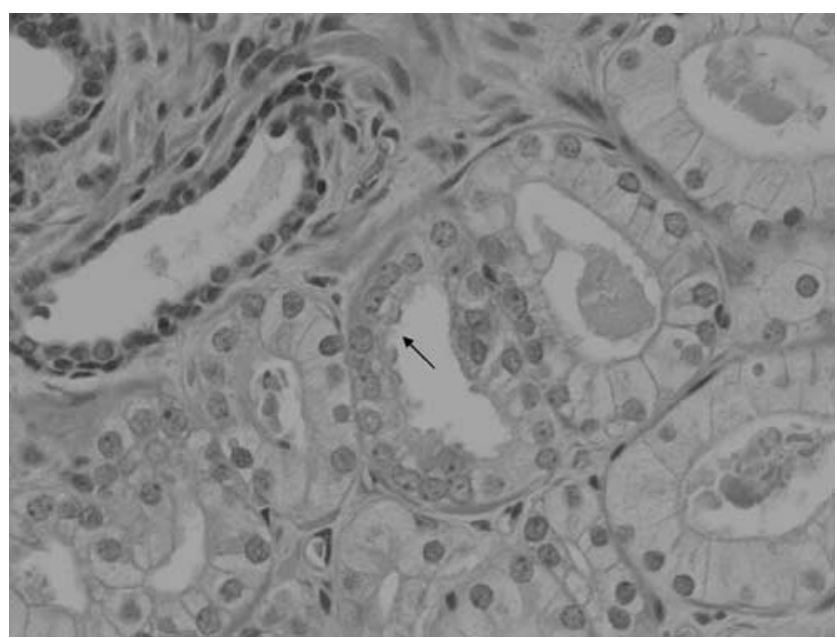

Figure $1 \mathrm{NED}$ in Gleason $7 \mathrm{CaP}$ specimen (courtesy of $\mathrm{Dr}$ Gandour-Edwards). study corroborated findings by Hoosein et $a .^{38}$ that NED markers correlated more with metastasis than locally advanced disease.

The role of NE cells in the development and progression of $\mathrm{CaP}$ is suggested by their central role in cell signaling pathways and several of these will be briefly outlined including bombesin/GRP, serotonin, PTHrP and possible pathways involved in angiogenesis (Figure 2). A negative regulator of proliferation, somatostatin, will also be discussed.

Bombesin/GRP is a potent mitogenic neuropeptide shown to stimulate CaP growth in cell culture, ${ }^{39}$ probably through its ability to induce c-fos and c-myc, thereby deregulating the cell cycle. ${ }^{40}$ GRP receptors are known to be distributed throughout the human prostate and Markwalder and Reubi ${ }^{4}$ showed they are overexpressed in CaP. Bombesin/GRP also causes $\mathrm{CaP}$ cell lines PC-3 and LNCaP to acquire greater invasive potential. $^{42}$

Serotonin is produced by most NE cells and is known to be associated with malignant transformation. ${ }^{7,43}$ Dizeyi et al. $^{44}$ showed several types of serotonin receptors exist in $\mathrm{CaP}$ tissue and cell lines. Higher grade cancer was shown to express a greater number of receptors and tissue growth was regulated by serotonin agonists and antagonists. The pathways by which serotonin acts are complex due to multiple receptor binding capabilities. It has been suggested that serotonin may be related to the potent oncoprotein ras $^{10}$ downstream from EGF receptors.

PTHrP is predominantly expressed in fetal tissues but is also produced by NE cells. It is overproduced by $\mathrm{CaP}$ tissue lines and can stimulate growth in a paracrine manner. ${ }^{45}$ PSA cleaves PTHrP destroying its ability to

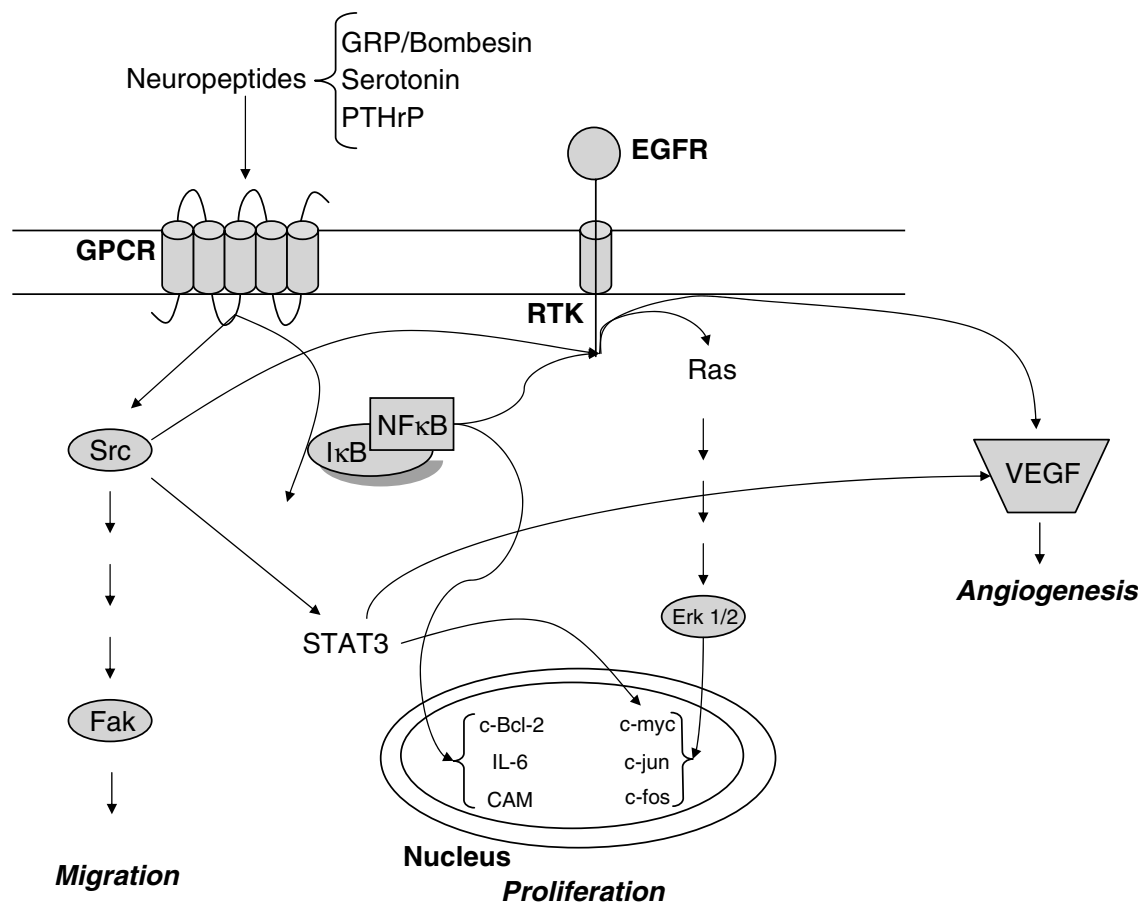

Figure 2 Summary of possible pathways involving NE cellular products in the development and progression of CaP. Neuropeptides activate G-protein-coupled receptors activating Src and NF- $\kappa$ B. In addition to their direct downstream effects, they may transactivate growth factor receptors. Abbreviations: CAM, cell adhesion molecule; EGFR, epithelial growth factor receptor; ERK1/2, extracellular signal-regulated kinase 1/2; FAK, focal adhesion kinase; GPCR, G-protein-coupled receptor; NF- $\kappa$ B, nuclear factor-kappa B; RTK, receptor tyrosine kinase; VEGF, vascular endothelial growth factor. 
bind receptors. This has led to the suggestion that as PSA expression decreases with ADT and CaP progression, PTHrP's growth-promoting activity increases. ${ }^{19}$

Angiogenesis is a necessary component of neoplastic growth because of increased energy requirements. NED is correlated with overall microvessel density in CaP. In addition, increased microvessel density is seen surrounding areas of NED and this effect is independent of tumor grade. ${ }^{46}$ Several products of NE cells are possible mediators of this effect. Vascular endothelial growth factor (VEGF) is produced by some NE cells, ${ }^{47}$ and VEGF staining NE cell density correlates with microvessel density. ${ }^{48}$ Although bombesin/GRP probably does not directly stimulate angiogenesis through tyrosine kinases, ${ }^{49}$ it may stimulate the nuclear factor-kappa B (NF- $\kappa \mathrm{B})$ angiogenesis pathway or enhance the angiogenic effects of growth factors by transactivating the EGF receptor. ${ }^{50-52}$ The fact that the EGF receptor is overexpressed in $\mathrm{CaP}$ may enhance this effect. ${ }^{53}$

Somatostatin is the one neuropeptide that may have a restraining influence upon prostatic growth and possibly neoplastic transformation. NE cells not only produce somatostatin, they also have receptors indicating autocrine as well as paracrine function. ${ }^{54}$ In $\mathrm{CaP}$ cells, somatostatin induces cell-cycle arrest and apoptosis, ${ }^{55}$ perhaps through receptor type 3 , which induces Bax. ${ }^{56}$ Somatostatin may inhibit neovascularization and prostatic growth both directly and through indirect effects mediated by insulin-like growth factor (IGF)-1. Somatostatin decreases growth hormone $(\mathrm{GH})$ release by the liver, which in turn decreases IGF-1 release. ${ }^{56}$ Acromegalic patients have increased GH and IGF-1, and the somatostatin agonist octreotide has been shown to decrease prostate size in a cohort of these patients. ${ }^{57}$

To summarize, NE cells express potent neuropeptides that mediate diverse biological processes such as cell growth, differentiation, transformation and invasion. Although NE cells do not stain for proliferative antibodies, they may be a source of paracrine factors that support CaP growth and progression. All of these complex interactions between signal-transduction pathways are undoubtedly involved in prostatic homeostasis. This fine balance may be disturbed not only by preexisting genetic faults but also via environmental toxins and carcinogens, diet, and the stress response, all of these acting through the microcellular hormonal milieu. Many of these microcellular environmental pathways converge through G-protein-coupled receptors via cAMP, protein kinase $\mathrm{A}$ and tyrosine kinases to activate mitogenactivated protein (MAP) kinases. Increasing aberrant activation of these pathways is independent of androgens, utilizing instead a complex interplay between classical growth factors and neuropeptides.

\section{NE cells during ADT}

The current treatment of metastatic $\mathrm{CaP}$ consists of medical or surgical AD. The prostatic microenvironmental conditions brought on by ADT apparently play a central role in the progression of $\mathrm{CaP}$ to the AI state. NE cells are thought to play an important part in effecting

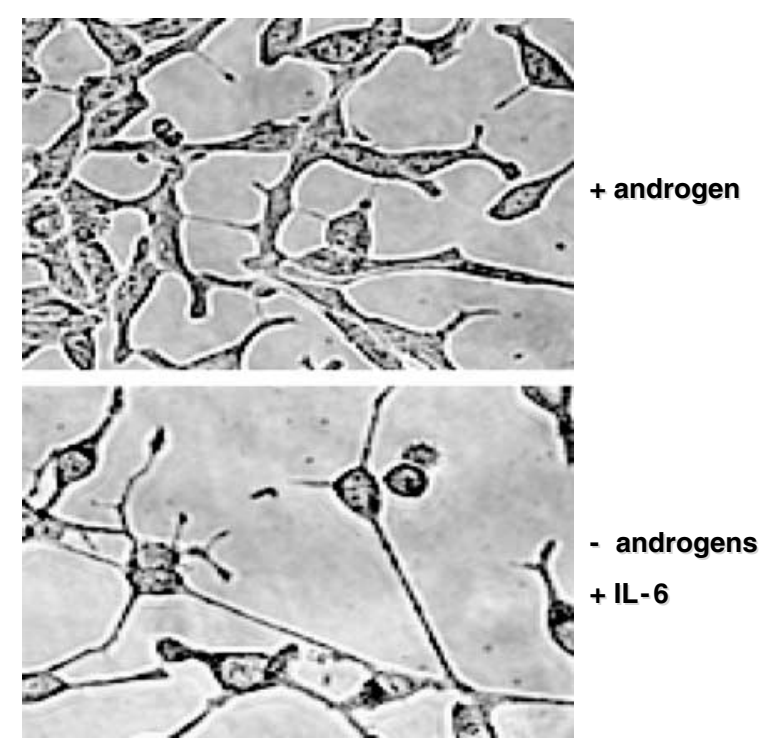

Figure 3 Morphological changes in LNCaP undergoing NED. In the presence of androgen, cells show normal fusiform morphology with unbranched cellular processes. Under AD conditions, cell bodies become compact and cellular processes lengthen and demonstrate a branching morphology.

this change based on several lines of evidence from both in vitro and in vivo studies.

Jongsma et al..$^{58}$ demonstrated that PC310 cells differentiate along NE lines when they are androgen deprived. AD of LNCaP cells results in NED (Figure 3), with the addition of IL- $6{ }^{21}$ IL- ${ }^{59}$ and neuropeptides. ${ }^{60}$ Human prostatic epithelial cells are similarly plastic and undergo NED in an AD mouse xenograft. ${ }^{61} \mathrm{CaP}$ patients treated with ADT demonstrate higher levels of CgA compared to androgen normal controls. ${ }^{6}$ When patients undergo surgical resection, prostatic specimens showed significantly increased NED in patients treated with neoadjuvant ADT compared to surgery only. ${ }^{63}$ Examination of gene expression shows higher levels of $\mathrm{CgA}$ mRNA in androgen-deprived $\mathrm{CaP}$ vs benign tissue. ${ }^{62}$

Feldman and Feldman ${ }^{64}$ have described a system for classifying mechanisms of AI growth during ADT into five categories. These are by no means mutually exclusive and may all be operative. Two of their categories form a useful framework for discussing the various possible actions of NE cells in the larger tissue microenvironment, specifically their possible role in supporting AI growth of $\mathrm{CaP}$ epithelial cells.

The 'outlaw receptor pathway' causes androgenic effects via crosstalk between the AR and other signaling pathways. The final common pathway for these effects seems to be phosphorylation of residues on the AR causing activation of downstream effects, probably through stimulation of MAP kinase. ${ }^{59,65}$ Theoretically, these signaling pathways can be activated by various biogenic amines produced by NE cells. ${ }^{7}$ Jongsma et al. ${ }^{66}$ showed that some androgen-depleted $\mathrm{CaP}$ cell lines can proliferate when stimulated by GRP, a neuropeptide produced by NE cells.

The gradual shift of normal to uncontrolled stimulation of proliferation may be accelerated by ADT through stimulation of greater growth factor production as shown by Culig et al. ${ }^{67}$ for EGF. Alternatively, decreased 
binding protein production may increase available growth factors. Androgens may regulate bioavailability of neuropeptides through regulation of binding proteins as has been shown for IGF/insulin-like growth factorbinding protein (IGFBP). ${ }^{68,69}$

The 'bypass pathway' includes mechanisms that no not require androgens or the $\mathrm{AR}$. The inhibition of apoptosis is an important mechanism for the progression of neoplasia and several mechanisms in CaP have been studied. Bcl-2 is a gene product that blocks apoptosis and is not normally expressed by prostate epithelium. ${ }^{70}$ The expression of this gene directly correlates with androgen responsiveness and has been shown to be induced upon ADT in a mouse xenograft model. ${ }^{71,72}$ Epithelial cells surrounding NE cells have higher levels of Bcl-2, suggesting that the microcellular environment produced by them induces greater cell survival. ${ }^{73}$ In addition, the NE cells express survivin, another antiapoptotic substance. $^{74}$

Growth factors may not only promote growth through outlaw receptor pathways, they may also inhibit apoptosis. Neuropeptides endothelin-1, bombesin, and growth factor IGF-1 activate the IGF-1 receptor, which phosphorylates AKT, a serine/threonine kinase. Activated AKT induces a strong antiapoptotic cellular signal. $^{75}$ The activity of AKT is opposed by PTEN (phosphatase and tensin homolog) and loss of PTEN is correlated with high-grade CaP. ${ }^{76}$ If IGF-1 activity is increased because of the AD-mediated decrease in IGFBP, the AKT pathway would overcome the inhibition of PTEN even if it has not been lost to mutation. Activation of the AKT pathway is probably important in AI progression. ${ }^{77}$

To summarize the role of NE cells in the AI state, it has been demonstrated that the products of NE cells stimulate AI growth and increasing anaplasia. All CaP cells from cell lines and patient samples have receptors for bombesin or NT. ${ }^{41}$ PC-3 cells display a growth response to $\mathrm{NT}^{16}$ and invasive/motility responses to bombesin. ${ }^{17,42,78}$ Elevated expression of GRP receptors are found in $\mathrm{CaP}$ specimens. ${ }^{41,79}$ Likewise, androgensensitive LNCaP cells were shown to become invasive after bombesin treatment. ${ }^{42}$ These and other findings suggest that NED of CaP cells may be a central link in supporting $\mathrm{AI} \mathrm{CaP}$ growth under AD conditions.

\section{NE cells after ADT}

Following ADT, NE features are an independent prognostic factor for progression of $\mathrm{CaP}{ }^{80}$ Following neoadjuvant ADT, surgical specimens showed greater NED compared to non-treated controls. ${ }^{63}$ In a retrospective study of $\mathrm{CaP}$ patients treated with chemotherapy, Cabrespine et al. $^{35}$ showed that CgA serum levels following ADT were independently related to treatment duration and were helpful in assessing patient response to chemotherapy.

It is unlikely that ADT always initiates NED or that this is an important feature in all $\mathrm{CaP}$ patients. However, if it is true that ADT of CaP tends to promote NED and supports continued progression of the tumor towards AI, then the natural question arises, can $\mathrm{CaP}$ associated with NED be treated?

\section{Treatment}

Treatment of AI CaP is the focus of intense research. Only those strategies that directly impact NE cellular signaling will be discussed here. These treatments can be separated into adjunctive and salvage categories. The former combines with ADT to prevent NED from taking place, while the latter attempts to block the biochemical pathways that result from existing NED tumors.

Adjunctive treatment strategies are very limited. We are not aware of any currently used adjunctive medications intended to prevent NED. So far, the only treatments intended to do this involve variations in the method or temporal aspects of AD. Sciarra and Di Silverio $^{81}$ have randomized patients with biochemical progression following prostatectomy into two monotherapy groups: medical castration or antiandrogen. They showed a significantly lower CgA level in the group treated with antiandrogen, although both groups showed significant increases.

Intermittent androgen deprivation (IAD) was developed as an attempt to delay the biochemical events that lead to AI during continuous ADT. The known side effects of ADT and concern for quality of life in advanced $\mathrm{CaP}$ have also fueled interest. At least one study has shown that IAD may also prevent or delay NED in locally advanced disease when compared to CAD. ${ }^{82}$ Metastatic disease also showed a trend toward lower serum CgA levels.

There are many treatments attempting to inhibit NED or at least block pathways NE cells use to drive CaP progression. Three known pathways that have excited interest are bombesin/GRP, serotonin and somatostatin. Antibodies against bombesin/GRP were shown to inhibit prostate cell line growth through MAP kinase pathways. ${ }^{83}$ Several studies have shown in vitro inhibition of $\mathrm{CaP}$ growth using serotonin inhibitors. ${ }^{44,84,85}$ Somatostatin has been used for various endocrine tumors for some time with varied success. ${ }^{7}$ The actions of somatostatin in $\mathrm{CaP}$ are more complex and the treatment effect may be through secondary mediators such as decreasing certain growth factors from NE cells. ${ }^{86}$ In addition, multiple somatostatin receptor types exist and different medications show different affinities. A recent review of the literature including seven studies using somatostatin analogues as monotherapy showed 'negative results' ${ }^{87}$ Direct growth factor antagonists of many varieties have been tested with mixed results. For example, suramin binds several growth factors and has shown moderate activity in $\mathrm{CaP}{ }^{88}$

Targeting downstream effectors of the pathways listed above may allow inhibition of multiple growth factors with one treatment. Src, a non-receptor tyrosine kinase activated by G-protein-coupled receptors, activates signal transducers and activator of transcription 3, which in turn activates transcription of VEGF, cyclinD1 and c-myc. Research at our institution has demonstrated the importance of Src as a central signal-transduction molecule in NED. ${ }^{60}$ An NCI-sponsored phase II trial of the Src inhibitor AZD0530 as treatment for AI CaP is planned to start by early 2007.

Another indirect method of targeting growth factors is growth hormone-releasing hormone (GHRH) antagonists. These medications have recently undergone 
improvements in efficacy and duration of action and have shown activity in vitro and in xenografts. ${ }^{89}$

Several combination therapy protocols have been used. GHRH antagonists in conjunction with bombesin/ GRP antagonists showed additive interference with IGF and EGF pathways in PC-3 cell lines and xenografts. ${ }^{89}$ The authors suggest this may allow future adjuvant use of these types of medication. Sciarra et al. ${ }^{90}$ suggest that somatostatin may influence the microenvironment in which $\mathrm{CaP}$ cells reside, allowing other treatments to more effectively destroy the malignancy. Recognizing the direct cytotoxic effects of estrogen on $\mathrm{CaP}^{91}$ they used the somatostatin agonist lanreotide in combination with ethinyl estradiol, theorizing a synergistic effect. Fourteen of 20 stage D3 patients demonstrated extended response time and symptomatic improvement. In addition, serum CgA decreased significantly, suggesting that a decrease in NE cell number or activity may be partially responsible for their results.

Chemotherapy targets dividing cells to induce genomic damage and apoptosis. Although NE cells are typically thought to be post-mitotic, ${ }^{5}$ at least one paper claims otherwise. ${ }^{92}$ Modern chemotherapy regimens may be useful according to a recent report, ${ }^{35}$ which demonstrated significant decreases in $\mathrm{CgA}$ in treated $\mathrm{AI}$ CaP patients.

One tremendous difficulty in developing new treatment strategies is assessing effectiveness in reaching the intended target. The focal nature of NED makes direct tissue analysis less accurate than serum markers such as CgA. ${ }^{93}$ However, all currently used serum markers are expressed by non-NE cells and therefore are affected by overall prostatic tissue volume rather that only NE cell number. Measuring patient outcomes, although helpful in identifying useful treatments, gives no information on specific pathways. Development of new markers for NED is a needed area of research. Other potential methods include radiolabeled monoclonal antibody imaging studies such as somatostatin receptor scintigraphy. Non-invasive visualization of various receptors in NE tissue shows great promise in treatment assessment.

\section{Conclusions}

In summary, AR-negative NE cells are present in normal prostatic tissue and may play a role in supporting initial neoplastic changes. ADT may induce microenvironmental changes that increase the activity of these cells. It is at least certain that they are selected for due to the lack of androgen. NE cells are capable of inducing transdifferentiation toward an NE phenotype in surrounding epithelial cells. The substances excreted by the increasing number of NE cells support the proliferation of existing $\mathrm{CaP}$ in an AI manner progressively increasing independence from androgen control. Greater understanding of these early post-castration molecular events will allow targeted adjunctive treatment of NED, thus decreasing the number of $\mathrm{CaP}$ cells that escape from hormonal control. New markers and associated imaging techniques for NED will allow molecular expression profiling, thus individualizing treatment based on the patient's unique microcellular environment.

\section{Acknowledgements}

This work was supported in part by NIH Grant KO8 DK60748-01 and Department of Defense Grant PC040161. Mention of trade name, proprietary product or specific equipment does not constitute a guaranty of warranty by the Department of Defense, nor does it imply approval to the exclusion of other products. The views expressed herein represent those of the authors and do not necessarily represent the position of the Department of Defense.

\section{References}

1 Jemal A, Siegel R, Ward E, Murray T, Xu J, Smigal C et al. Cancer statistics, 2006. CA Cancer J Clin 2006; 56: 106-130.

2 Huggins C, Hodges C. Studies on prostate cancer: I. The effect of estrogen and of androgen injection on serum phosphatases in metastatic carcinoma of the prostate. Cancer Res 1941; 1: 293-297.

3 Eisenberger MA, Blumenstein BA, Crawford ED, Miller G, McLeod DG, Loehrer PJ et al. Bilateral orchiectomy with or without flutamide for metastatic prostate cancer. $N$ Engl J Med 1998; 339: 1036-1042.

4 Krijnen JL, Janssen PJ, Ruizeveld de Winter JA, van Krimpen H, Schroder FH, van der Kwast TH. Do neuroendocrine cells in human prostate cancer express androgen receptor? Histochemistry 1993; 100: 393-398.

5 Bonkhoff H. Neuroendocrine cells in benign and malignant prostate tissue: morphogenesis, proliferation, and androgen receptor status. Prostate Suppl 1998; 8: 18-22.

6 Pretl K. Zur Frage der Endokrinie der menschlichen Vorsteherdruse. Virchows Arch A 1944; 312: 392-404.

7 Abrahamsson PA. Neuroendocrine cells in tumour growth of the prostate. Endocr Relat Cancer 1999; 6: 503-519.

8 Heasley LE. Autocrine and paracrine signaling through neuropeptide receptors in human cancer. Oncogene 2001; 20: 1563-1569.

9 Andrew A, Kramer B, Rawdon BB. Gut and pancreatic amine precursor uptake and decarboxylation cells are not neural crest derivatives. Gastroenterology 1983; 84: 429-431.

10 Tutton PJ, Barkla DH. Biogenic amines as regulators of the proliferative activity of normal and neoplastic intestinal epithelial cells [review]. Anticancer Res 1987; 7: 1-12.

11 Bonkhoff $\mathrm{H}$, Stein U, Remberger K. Multidirectional differentiation in the normal, hyperplastic, and neoplastic human prostate: simultaneous demonstration of cell-specific epithelial markers. Hum Pathol 1994; 25: 42-46.

12 Aumuller G, Leonhardt M, Janssen M, Konrad L, Bjartell A, Abrahamsson PA. Neurogenic origin of human prostate endocrine cells. Urology 1999; 53: 1041-1048.

13 Luttrell LM, Daaka Y, Lefkowitz RJ. Regulation of tyrosine kinase cascades by G-protein-coupled receptors. Curr Opin Cell Biol 1999; 11: 177-183.

14 Aprikian AG, Han K, Chevalier S, Bazinet M, Viallet J. Bombesin specifically induces intracellular calcium mobilization via gastrin-releasing peptide receptors in human prostate cancer cells. J Mol Endocrinol 1996; 16: 297-306.

15 Han K, Viallet J, Chevalier S, Zheng W, Bazinet M, Aprikian AG. Characterization of intracellular calcium mobilization by bombesin-related neuropeptides in PC-3 human prostate cancer cells. Prostate 1997; 31: 53-60.

16 Seethalakshmi L, Mitra SP, Dobner PR, Menon M, Carraway RE. Neurotensin receptor expression in prostate cancer cell line and growth effect of NT at physiological concentrations. Prostate 1997; 31: 183-192.

17 Festuccia C, Guerra F, D'Ascenzo S, Giunciuglio D, Albini A, Bologna M. In vitro regulation of pericellular proteolysis in 
prostatic tumor cells treated with bombesin. Int J Cancer 1998; 75: 418-431.

18 Nakada SY, di Sant'Agnese PA, Moynes RA, Hiipakka RA, Liao $\mathrm{S}$, Cockett AT et al. The androgen receptor status of neuroendocrine cells in human benign and malignant prostatic tissue. Cancer Res 1993; 53: 1967-1970.

19 Iwamura M, Hellman J, Cockett AT, Lilja H, Gershagen S. Alteration of the hormonal bioactivity of parathyroid hormonerelated protein (PTHrP) as a result of limited proteolysis by prostate-specific antigen. Urology 1996; 48: 317-325.

20 Diaz M, Abdul M, Hoosein N. Modulation of neuroendocrine differentiation in prostate cancer by interleukin-1 and -2 . Prostate Suppl 1998; 8: 32-36.

21 Spiotto MT, Chung TD. STAT3 mediates IL-6-induced neuroendocrine differentiation in prostate cancer cells. Prostate 2000; 42: 186-195.

22 Aprikian AG, Cordon-Cardo C, Fair WR, Reuter VE. Characterization of neuroendocrine differentiation in human benign prostate and prostatic adenocarcinoma. Cancer 1993; 71: 3952-3965.

23 Cohen RJ, Glezerson G, Haffejee Z. Prostate-specific antigen and prostate-specific acid phosphatase in neuroendocrine cells of prostate cancer. Arch Pathol Lab Med 1992; 116: 65-66.

24 Vashchenko N, Abrahamsson PA. Neuroendocrine differentiation in prostate cancer: implications for new treatment modalities. Eur Urol 2005; 47: 147-155.

25 Bang YJ, Pirnia F, Fang WG, Kang WK, Sartor O, Whitesell L et al. Terminal neuroendocrine differentiation of human prostate carcinoma cells in response to increased intracellular cyclic AMP. Proc Natl Acad Sci USA 1994; 91: 5330-5334.

26 Deeble PD, Murphy DJ, Parsons SJ, Cox ME. Interleukin-6- and cyclic AMP-mediated signaling potentiates neuroendocrine differentiation of LNCaP prostate tumor cells. Mol Cell Biol 2001; 21: 8471-8482.

27 Cox ME, Deeble PD, Lakhani S, Parsons SJ. Acquisition of neuroendocrine characteristics by prostate tumor cells is reversible: implications for prostate cancer progression. Cancer Res 1999; 59: 3821-3830.

28 Iwamura M, Gershagen S, Lapets O, Moynes R, Abrahamsson PA, Cockett AT et al. Immunohistochemical localization of parathyroid hormone-related protein in prostatic intraepithelial neoplasia. Hum Pathol 1995; 26: 797-801.

29 Bostwick DG, Dousa MK, Crawford BG, Wollan PC. Neuroendocrine differentiation in prostatic intraepithelial neoplasia and adenocarcinoma. Am J Surg Pathol 1994; 18: 1240-1246.

30 Abrahamsson PA. Neuroendocrine differentiation in prostatic carcinoma. Prostate 1999; 39: 135-148.

31 Bonkhoff H, Wernert N, Dhom G, Remberger K. Relation of endocrine-paracrine cells to cell proliferation in normal, hyperplastic, and neoplastic human prostate. Prostate 1991; 19: 91-98.

32 Bonkhoff H, Stein U, Remberger K. Endocrine-paracrine cell types in the prostate and prostatic adenocarcinoma are postmitotic cells. Hum Pathol 1995; 26: 167-170.

33 Berruti A, Mosca A, Tucci M, Terrone C, Torta M, Tarabuzzi R et al. Independent prognostic role of circulating chromogranin A in prostate cancer patients with hormone-refractory disease. Endocr Relat Cancer 2005; 12: 109-117.

34 Taplin ME, George DJ, Halabi S, Sanford B, Febbo PG, Hennessy KT et al. Prognostic significance of plasma chromogranin a levels in patients with hormone-refractory prostate cancer treated in Cancer and Leukemia Group B 9480 study. Urology 2005; 66: 386-391.

35 Cabrespine A, Guy L, Gachon F, Cure H, Chollet P, Bay JO. Circulating chromogranin a and hormone refractory prostate cancer chemotherapy. J Urol 2006; 175: 1347-1352.

36 Kim J, Palmer JL, Finn L, Hodges S, Bowes VV, Deftos L et al. The pattern of serum markers in patients with androgen-independent adenocarcinoma of the prostate. Urol Oncol 2000; 5: 97-103.
37 Cussenot O, Villette JM, Valeri A, Cariou G, Desgrandchamps F, Cortesse A et al. Plasma neuroendocrine markers in patients with benign prostatic hyperplasia and prostatic carcinoma. J Urol 1996; 155: 1340-1343.

38 Hoosein N, Abdul M, McCabe R, Gero A, Deftos LJ, Banks M et al. Clinical significance of elevation in neuroendocrine factors and interleukin-6 in metastatic prostate cancer. Urol Oncol 1995; 1: $246-251$.

39 Bologna M, Festuccia C, Muzi P, Biordi L, Ciomei M. Bombesin stimulates growth of human prostatic cancer cells in vitro. Cancer 1989; 63: 1714-1720.

40 Rozengurt E, Sinnett-Smith J. Early signals underlying the induction of the c-fos and c-myc genes in quiescent fibroblasts: studies with bombesin and other growth factors. Prog Nucleic Acid Res Mol Biol 1988; 35: 261-295.

41 Markwalder R, Reubi JC. Gastrin-releasing peptide receptors in the human prostate: relation to neoplastic transformation. Cancer Res 1999; 59: 1152-1159.

42 Hoosein NM, Logothetis CJ, Chung LW. Differential effects of peptide hormones bombesin, vasoactive intestinal polypeptide and somatostatin analog RC-160 on the invasive capacity of human prostatic carcinoma cells. J Urol 1993; 149: 1209-1213.

43 Julius D, Livelli TJ, Jessell TM, Axel R. Ectopic expression of the serotonin 1c receptor and the triggering of malignant transformation. Science 1989; 244: 1057-1062.

44 Dizeyi N, Bjartell A, Nilsson E, Hansson J, Gadaleanu V, Cross $\mathrm{N}$ et al. Expression of serotonin receptors and role of serotonin in human prostate cancer tissue and cell lines. Prostate 2004; 59: 328-336.

45 Iwamura M, Wu G, Abrahamsson PA, di Sant'Agnese PA, Cockett AT, Deftos LJ. Parathyroid hormone-related protein is expressed by prostatic neuroendocrine cells. Urology 1994; 43: 667-674.

46 Grobholz R, Bohrer MH, Siegsmund M, Junemann KP, Bleyl U, Woenckhaus $M$. Correlation between neovascularisation and neuroendocrine differentiation in prostatic carcinoma. Pathol Res Pract 2000; 196: 277-284.

47 Harper ME, Glynne-Jones E, Goddard L, Thurston VJ, Griffiths K. Vascular endothelial growth factor (VEGF) expression in prostatic tumours and its relationship to neuroendocrine cells. Br J Cancer 1996; 74: 910-916.

48 Borre M, Nerstrom B, Overgaard J. Association between immunohistochemical expression of vascular endothelial growth factor (VEGF), VEGF-expressing neuroendocrinedifferentiated tumor cells, and outcome in prostate cancer patients subjected to watchful waiting. Clin Cancer Res 2000; 6: 1882-1890.

49 Busby JE, Shih SJ, Yang JC, Kung HJ, Evans CP. Angiogenesis is not mediated by prostate cancer neuropeptides. Angiogenesis 2003; 6: 289-293.

50 Nelson JB, Chan-Tack K, Hedican SP, Magnuson SR, Opgenorth TJ, Bova GS et al. Endothelin-1 production and decreased endothelin B receptor expression in advanced prostate cancer. Cancer Res 1996; 56: 663-668.

51 Prenzel N, Zwick E, Daub H, Leserer M, Abraham R, Wallasch $\mathrm{C}$ et al. EGF receptor transactivation by G-protein-coupled receptors requires metalloproteinase cleavage of proHB-EGF. Nature 1999; 402: 884-888.

52 Levine L, Lucci III JA, Pazdrak B, Cheng JZ, Guo YS, Townsend Jr CM et al. Bombesin stimulates nuclear factor kappa B activation and expression of proangiogenic factors in prostate cancer cells. Cancer Res 2003; 63: 3495-3502.

53 Sherwood ER, Lee C. Epidermal growth factor-related peptides and the epidermal growth factor receptor in normal and malignant prostate. World J Urol 1995; 13: 290-296.

54 Abrahamsson PA, Anderson J, Boccon-Gibod L, Schulman C, Studer UE, Wirth M. Risks and benefits of hormonal manipulation as monotherapy or adjuvant treatment in localised prostate cancer. Eur Urol 2005; 48: 900-905.

55 Brevini TA, Bianchi R, Motta M. Direct inhibitory effect of somatostatin on the growth of the human prostatic cancer cell 
line LNCaP: possible mechanism of action. J Clin Endocrinol Metab 1993; 77: 626-631.

56 Hansson J, Abrahamsson PA. Neuroendocrine pathogenesis in adenocarcinoma of the prostate. Ann Oncol 2001; 12 (Suppl 2): S145-S152.

57 Colao A, Marzullo P, Ferone D, Spiezia S, Cerbone G, Marino V et al. Prostatic hyperplasia: an unknown feature of acromegaly. J Clin Endocrinol Metab 1998; 83: 775-779.

58 Jongsma J, Oomen MH, Noordzij MA, Van Weerden WM, Martens GJ, van der Kwast TH et al. Androgen deprivation of the PC-310 (correction of prohormone convertase-310) human prostate cancer model system induces neuroendocrine differentiation. Cancer Res 2000; 60: 741-748.

59 Lee LF, Louie MC, Desai SJ, Yang J, Chen HW, Evans CP et al. Interleukin-8 confers androgen-independent growth and migration of LNCaP: differential effects of tyrosine kinases Src and FAK. Oncogene 2004; 23: 2197-2205.

60 Lee LF, Guan J, Qiu Y, Kung HJ. Neuropeptide-induced androgen independence in prostate cancer cells: roles of nonreceptor tyrosine kinases Etk/Bmx, Src, and focal adhesion kinase. Mol Cell Biol 2001; 21: 8385-8397.

61 Huss WJ, Gregory CW, Smith GJ. Neuroendocrine cell differentiation in the CWR22 human prostate cancer xenograft: association with tumor cell proliferation prior to recurrence. Prostate 2004; 60: 91-97.

62 Monti S, Sciarra A, Falasca P, Di Silverio F. Serum concentrations and prostatic gene expression of chromogranin A and PSA in patients affected by prostate cancer and benign prostatic hyperplasia. J Endocrinol Invest 2000; 23: 53.

63 Ahlgren G, Pedersen K, Lundberg S, Aus G, Hugosson J, Abrahamsson PA. Regressive changes and neuroendocrine differentiation in prostate cancer after neoadjuvant hormonal treatment. Prostate 2000; 42: 274-279.

64 Feldman BJ, Feldman D. The development of androgenindependent prostate cancer. Nat Rev Cancer 2001; 1: 34-45.

65 Ueda T, Bruchovsky N, Sadar MD. Activation of the androgen receptor $\mathrm{N}$-terminal domain by interleukin-6 via MAPK and STAT3 signal transduction pathways. J Biol Chem 2002; 277: 7076-7085.

66 Jongsma J, Oomen MH, Noordzij MA, Romijn JC, van Der Kwast TH, Schroder FH et al. Androgen-independent growth is induced by neuropeptides in human prostate cancer cell lines. Prostate 2000; 42: 34-44.

67 Culig Z, Hobisch A, Cronauer MV, Radmayr C, Hittmair A, Zhang $\mathrm{J}$ et al. Regulation of prostatic growth and function by peptide growth factors. Prostate 1996; 28: 392-405.

68 Hampel OZ, Kattan MW, Yang G, Haidacher SJ, Saleh GY, Thompson TC et al. Quantitative immunohistochemical analysis of insulin-like growth factor binding protein-3 in human prostatic adenocarcinoma: a prognostic study. J Urol 1998; 159: 2220-2225.

69 Gregory CW, Kim D, Ye P, D'Ercole AJ, Pretlow TG, Mohler JL et al. Androgen receptor up-regulates insulin-like growth factor binding protein-5 (IGFBP-5) expression in a human prostate cancer xenograft. Endocrinology 1999; 140: 2372-2381.

70 McDonnell TJ, Troncoso P, Brisbay SM, Logothetis C, Chung LW, Hsieh JT et al. Expression of the protooncogene bcl-2 in the prostate and its association with emergence of androgen-independent prostate cancer. Cancer Res 1992; 52: 6940-6944.

71 Furuya Y, Krajewski S, Epstein JI, Reed JC, Isaacs JT. Expression of bcl-2 and the progression of human and rodent prostatic cancers. Clin Cancer Res 1996; 2: 389-398.

72 Liu AY, Corey E, Bladou F, Lange PH, Vessella RL. Prostatic cell lineage markers: emergence of BCL2+ cells of human prostate cancer xenograft LuCaP 23 following castration. Int J Cancer 1996; 65: 85-89.

73 Ambrosini G, Adida C, Altieri DC. A novel anti-apoptosis gene, survivin, expressed in cancer and lymphoma. Nat Med 1997; 3: 917-921.
74 Xing N, Qian J, Bostwick D, Bergstralh E, Young CY. Neuroendocrine cells in human prostate over-express the anti-apoptosis protein survivin. Prostate 2001; 48: 7-15.

75 Sumitomo M, Milowsky MI, Shen R, Navarro D, Dai J, Asano $\mathrm{T}$ et al. Neutral endopeptidase inhibits neuropeptide-mediated transactivation of the insulin-like growth factor receptor-Akt cell survival pathway. Cancer Res 2001; 61: 3294-3298.

76 McMenamin ME, Soung P, Perera S, Kaplan I, Loda M, Sellers WR. Loss of PTEN expression in paraffin-embedded primary prostate cancer correlates with high Gleason score and advanced stage. Cancer Res 1999; 59: 4291-4296.

77 Hansson J, Abrahamsson PA. Neuroendocrine differentiation in prostatic carcinoma. Scand J Urol Nephrol Suppl 2003; 212: 28-36.

78 Aprikian AG, Tremblay L, Han K, Chevalier S. Bombesin stimulates the motility of human prostate-carcinoma cells through tyrosine phosphorylation of focal adhesion kinase and of integrin-associated proteins. Int J Cancer 1997; 72: 498-504.

79 Bartholdi MF, Wu JM, Pu H, Troncoso P, Eden PA, Feldman RI. In situ hybridization for gastrin-releasing peptide receptor (GRP receptor) expression in prostatic carcinoma. Int J Cancer 1998; 79: 82-90.

80 Krijnen JL, Bogdanowicz JF, Seldenrijk CA, Mulder PG, van der Kwast $\mathrm{TH}$. The prognostic value of neuroendocrine differentiation in adenocarcinoma of the prostate in relation to progression of disease after endocrine therapy. I Urol 1997; 158: 171-174

81 Sciarra A, Di Silverio F. Effect of nonsteroidal antiandrogen monotherapy versus castration therapy on neuroendocrine differentiation in prostate carcinoma. Urology 2004; 63: 523-527.

82 Sciarra A, Monti S, Gentile V, Mariotti G, Cardi A, Voria G et al. Variation in chromogranin A serum levels during intermittent versus continuous androgen deprivation therapy for prostate adenocarcinoma. Prostate 2003; 55: 168-179.

83 Stangelberger A, Schally AV, Varga JL, Zarandi M, Cai RZ, Baker B et al. Inhibition of human androgen-independent PC-3 and DU-145 prostate cancers by antagonists of bombesin and growth hormone releasing hormone is linked to PKC, MAPK and c-jun intracellular signalling. Eur J Cancer 2005; 41: 27352744.

84 Abdul M, Anezinis PE, Logothetis CJ, Hoosein NM. Growth inhibition of human prostatic carcinoma cell lines by serotonin antagonists. Anticancer Res 1994; 14: 1215-1220.

85 Abdul M, Logothetis CJ, Hoosein NM. Growth-inhibitory effects of serotonin uptake inhibitors on human prostate carcinoma cell lines. J Urol 1995; 154: 247-250.

86 Hejna M, Schmidinger M, Raderer M. The clinical role of somatostatin analogues as antineoplastic agents: much ado about nothing? Ann Oncol 2002; 13: 653-668.

87 Sciarra A, Bosman C, Monti G, Gentile V, Gomez AM, Ciccariello $\mathrm{M}$ et al. Somatostatin analogues and estrogens in the treatment of androgen ablation refractory prostate adenocarcinoma. J Urol 2004; 172: 1775-1783.

88 Kaur M, Reed E, Sartor O, Dahut W, Figg WD. Suramin's development: what did we learn? Invest New Drugs 2002; 20: 209-219.

89 Plonowski A, Schally AV, Varga JL, Rekasi Z, Hebert F, Halmos $\mathrm{G}$ et al. Potentiation of the inhibitory effect of growth hormonereleasing hormone antagonists on PC-3 human prostate cancer by bombesin antagonists indicative of interference with both IGF and EGF pathways. Prostate 2000; 44: 172-180.

90 Sciarra A, Cardi A, Dattilo C, Mariotti G, Di Monaco F, Di Silverio F. New perspective in the management of neuroendocrine differentiation in prostate adenocarcinoma. Int J Clin Pract 2006; 60: 462-470.

91 Robertson CN, Roberson KM, Padilla GM, O'Brien ET, Cook JM, Kim CS et al. Induction of apoptosis by diethylstilbestrol in hormone-insensitive prostate cancer cells. I Natl Cancer Inst 1996; 88: 908-917. 
92 Angelsen A, Syversen U, Haugen OA, Stridsberg M, Mjolnerod OK, Waldum HL. Neuroendocrine differentiation in carcinomas of the prostate: do neuroendocrine serum markers reflect immunohistochemical findings? Prostate 1997; 30: 1-6.

93 di Sant'Agnese PA. Neuroendocrine differentiation in carcinoma of the prostate. Diagnostic, prognostic, and therapeutic implications. Cancer 1992; 70: 254-268.

94 Yashi M, Nukui A, Kurokawa S, Ochi M, Ishikawa S, Goto K et al. Elevated serum progastrin-releasing peptide (31-98) level is a predictor of short response duration after hormonal therapy in metastatic prostate cancer. Prostate 2003; 56: 305-312.

95 Salido M, Vilches J, Lopez A, Roomans GM. Neuropeptides bombesin and calcitonin inhibit apoptosis-related elemental changes in prostate carcinoma cell lines. Cancer 2002; 94: 368-377.

96 Zukowska-Grojec Z, Karwatowska-Prokopczuk E, Fisher TA, Ji H. Mechanisms of vascular growth-promoting effects of neuropeptide Y: role of its inducible receptors. Regul Pept 1998; 75-76: 231-238.
97 Martinez A, Zudaire E, Portal-Nunez S, Guedez L, Libutti SK, Stetler-Stevenson WG et al. Proadrenomedullin NH2-terminal 20 peptide is a potent angiogenic factor, and its inhibition results in reduction of tumor growth. Cancer Res 2004; 64: 6489-6494.

98 Ohinata K, Inui A, Asakawa A, Wada K, Wada E, Yoshikawa M. Proadrenomedullin N-terminal 20 peptide (PAMP) elevates blood glucose levels via bombesin receptor in mice. FEBS Lett 2000; 473: 207-211.

99 Dizeyi N, Bjartell A, Hedlund P, Tasken KA, Gadaleanu V, Abrahamsson PA. Expression of serotonin receptors 2B and 4 in human prostate cancer tissue and effects of their antagonists on prostate cancer cell lines. Eur Urol 2005; 47: 895-900.

100 Chevalier S, Defoy I, Lacoste J, Hamel L, Guy L, Begin LR et al. Vascular endothelial growth factor and signaling in the prostate: more than angiogenesis. Mol Cell Endocrinol 2002; 189: $169-179$. 


\title{
Nonreceptor Tyrosine Kinases in Prostate Cancer
}

\author{
Yu-Ming Chang ${ }^{\star}$, Hsing-Jien Kung ${ }^{\star, \dagger, \ddagger}$ and Christopher P. Evans ${ }^{\star, \ddagger}$
}

Departments of *Urology and ${ }^{\dagger}$ Biological Chemistry, University of California at Davis, Sacramento, CA 95817, USA; ${ }^{\ddagger}$ Cancer Center, University of California at Davis, Sacramento, CA 95817, USA

\section{Abstract}

BACKGROUND: Carcinoma of the prostate (CaP) is the most commonly diagnosed cancer in men in the United States. Signal transduction molecules such as tyrosine kinases play important roles in CaP. Src, a nonreceptor tyrosine kinase (NRTK) and the first proto-oncogene discovered is shown to participate in processes such as cell proliferation and migration in CaP. Underscoring NRTK's and, specifically, Src's importance in cancer is the recent approval by the US Food and Drug Administration of dasatinib, the first commercial Src inhibitor for clinical use in chronic myelogenous leukemia (CML). In this review we will focus on NRTKs and their roles in the biology of CaP. MATERIALS AND METHODS: Publicly available literature from PubMed regarding the topic of members of NRTKs in CaP was searched and reviewed. RESULTS: Src, FAK, JaK1/2, and ETK are involved in processes indispensable to the biology of CaP: cell growth, migration, invasion, angiogenesis, and apoptosis. CONCLUSIONS: Src emerges as a common signaling and regulatory molecule in multiple biological processes in CaP. Src's relative importance in particular stages of $\mathrm{CaP}$, however, required further definition. Continued investigation of NRTKs will increase our understanding of their biological function and potential role as new therapeutic targets. Neoplasia (2007) 9, 90-100

Keywords: Nonreceptor tyrosine kinase, prostate cancer, Src, FAK, ETK.

\section{Introduction}

Carcinoma of the prostate $(\mathrm{CaP})$ is the most commonly diagnosed cancer in American men, consisting of more than $33 \%$ of all new cancer cases. Though many patients are diagnosed with $\mathrm{CaP}$, it has a relatively low mortality rate when compared to other cancers. Nevertheless, it remains the third leading cause of cancer-related deaths in men in the United States, with about 27,350 estimated CaPrelated deaths in 2006 in the United States [1]. Because $\mathrm{CaP}$ growth is facilitated by androgen exposure and because androgen withdrawal leads to apoptosis of $\mathrm{CaP}$ cells, the current treatment of choice for recurrent or metastatic $\mathrm{CaP}$ includes castration through chemical or surgical means. Nearly all patients, however, relapse with androgen- independent (AI) disease after androgen ablation therapy. Ultimately, the uncontrolled growth of $\mathrm{Al}$ metastatic tumors leads to patient mortality.

Tyrosine kinases (TKs) are signaling molecules well known for their roles in human diseases such as diabetes and cancer. Indeed, v-Src sarcoma (Schmidt-Ruppin A-2) viral oncogene homolog (Src), a nonreceptor tyrosine kinase (NRTK), was the first proto-oncogene discovered. More than a quarter of a century has passed since the discovery of Src, and the studies on TKs are coming to fruition with the development and use of tyrosine kinase-based target-specific therapy such as Gleevec, Iressa, and Herceptin for therapy against chronic myelogenous leukemia (CML), lung cancer, and breast cancer, respectively. Dasatinib, a dual Src/v-Abl Abelson murine leukemia viral oncogene homolog (Abl) inhibitor with antimigratory activity in prostate cancer cells in culture was recently approved by the US Food and Drug Administration for use in patients with $\mathrm{CML}$ [2]. Further underscoring the importance of NRTKs, AZD0530 is another dual Src/Abl inhibitor that is currently in multicenter phase II clinical trials for multiple types

\footnotetext{
Abbreviations: Abl, v-Abl Abelson murine leukemia viral oncogene homolog; Al, androgenindependent; Akt, v-akt murine thymoma viral oncogene homolog 1; AR, androgen receptor; ARG, Abelson-related gene; Bcr, breakpoint cluster region; BrK/PTK6, breast tumor kinase/ protein tyrosine kinase 6 ; $\mathrm{BPH}$, benign prostatic hypertrophy; $B R C A 1$, breast cancer susceptibility gene 1 ; CaP, carcinoma of the prostate; $\mathrm{CML}$, chronic myelogenous leukemia; CRKII, v-crk avian sarcoma virus CT10 oncogene homolog; CSK, C-terminal Src kinase; DOC-2/DAB2, differentially expressed in ovarian cancer-2/disabled-2; EGF, epidermal growth factor; ER, estrogen receptor; ERK1/2, extracellular signal-regulated kinase 1/2; ET1, endothelin; ETK/BMX, endothelial/epithelial tyrosine kinase/bone marrow X kinase; FAK, focal adhesion kinase; FeR, FpS/FeS - related tyrosine kinase; FeS/FpS, feline sarcoma oncogene/ fujinami avian sarcoma viral oncogene homolog; FGR, Gardner-Rasheed feline sarcoma viral (v-FGR) oncogene homolog; Fyn, Fyn oncogene related to Src, FGR, Yes; HIF-1 $\alpha$, hypoxiainducible factor $1 \alpha$; IGF-1, insulin-like growth factor 1; IL, interleukin; JaK, Janus kinase; KAl1/ CD82, Kangai 1/cluster designation 82; LcK, lymphocyte-specific protein tyrosine kinase; Lyn, v-Yes-1 Yamaguchi sarcoma viral-related oncogene homolog; LPA, lysophosphatidic acid; Met, met proto-oncogene (hepatocyte growth factor receptor); MMP, matrix metalloproteinase; NEP, neutral endopeptidase; NRTK, nonreceptor tyrosine kinase; p130CAS, p130 CRKassociated substrate; PAK1, p21-associated kinase 1; PDGF, platelet-derived growth factor; PI3K, phosphatidylinositol 3-kinase; PKC, protein kinase C; PSA, prostate-specific antigen; PTEN, phosphatase and tensin homolog; PYK2/CAK $\beta$, proline-rich tyrosine kinase 2/cell adhesion kinase 3 ; Raf, v-raf-1 murine leukemia viral oncogene homolog 1; Ras, v-Ha-ras Harvey rat sarcoma viral oncogene homolog; SH, Src homology; Src, v-Src sarcoma (Schmidt-Ruppin A-2) viral oncogene homolog; STAT, signal and transducer of transcription; SYK, spleen tyrosine kinase; Tec, Tec protein kinase; TGF, tumor growth factor; TIMP, tissue inhibitor of metalloproteinase; TKIP, tyrosine kinase inhibitor peptide; TnK, tyrosine kinase nonreceptor; TyK2, tyrosine kinase 2; VEGF, vascular endothelial growth factor; Yes, v-Yes-1 Yamaguchi sarcoma viral oncogene homolog 1

Address all correspondence to: Christopher P. Evans, Department of Urology, University of California at Davis, Suite 3500, 4860 Y Street, Sacramento, CA 95817.

E-mail: cpevans@ucdavis.edu

Received 29 October 2006; Revised 2 January 2007; Accepted 2 January 2007.
}

Copyright $\odot 2007$ Neoplasia Press, Inc. All rights reserved 1522-8002/07/\$25.00 DOI 10.1593/neo.06694 
of malignancies, including prostate cancer. In this review we will focus on each of the NRTKs and what is known about their respective roles in the biological processes of cell proliferation, migration, invasion, apoptosis, and angiogenesis in $\mathrm{CaP}$.

There are several NRTK families. These are classified based on their structural similarities (Figure 1): Abl, tyrosine kinase nonreceptor (TnK), C-terminal Src kinase (CSK), focal adhesion kinase (FAK), feline sarcoma oncogene/ fujinami avian sarcoma viral oncogene homolog (FeS), Janus kinase (JaK), Src, Tec protein kinase (Tec), and spleen tyrosine kinase (SYK). Though these NRTK families are extensively and individually reviewed elsewhere, this

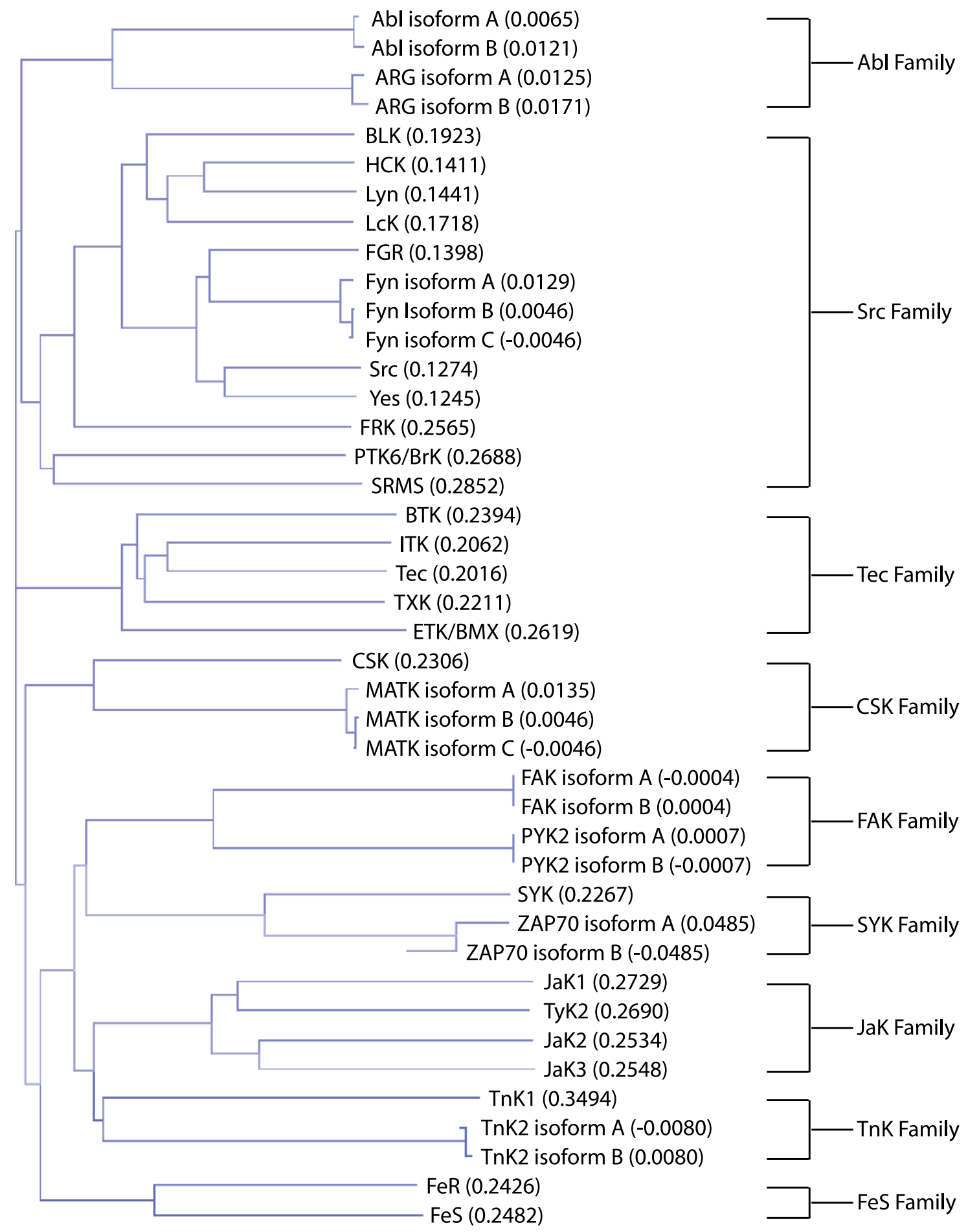

Figure 1. NRTK families and their members in a guide tree. Protein sequences are obtained from Entrez Gene and aligned using Vector NTI Advance software (Invitrogen, Carlsbad, CA). Vector NTI Advance uses the neighbor-joining method of phylogenetic tree construction by Saitou and Nei [127]. The numbers in parentheses after each kinase reflect the calculated distance values between pairs of analyzed sequences. 
is the first time they are summarily discussed in relation to $\mathrm{CaP}$.

\section{Profiles of NRTKs in CaP}

In 1996, Robinson et al. [3] led the first attempt at profiling the expression of TKs in CaP. Using a modified and improved reverse transcriptase-polymerase chain reaction approach, they identified nine NRTKs expressed in CWR22, a CaP xenograft. NRTKs include lymphocyte-specific protein tyrosine kinase (LCK), v-Yes-1 Yamaguchi sarcoma viral oncogene homolog 1(Yes), Abl, Abelson-related gene ( $A R G$ ), JaK1, tyrosine kinase 2 (TyK2), and endothelial/epithelial tyrosine kinase/bone marrow $X$ kinase (ETK/BMX). Fur- thermore, $A R G$ was found in several other $\mathrm{CaP}$ cell lines, which include PC-3, DU145, and LNCaP. In a similar study, Moore et al. [4] used degenerate polymerase chain reaction against conserved kinase catalytic subdomains and found that Abl, JaK1, JaK2, and TyK2 are expressed in surgically removed CaP tissues. In CWR22Rv1, DU145, LNCaP and PC3 cell lines, 18 NRTKs are expressed. This was confirmed by our internal data and also cross-referenced with several published reports (Figure 2).

\section{Src Family}

As the first human proto-oncogene discovered, Src's history spans nearly a century and has been extensively reviewed [5-22]. Members of the Src family include B lymphoid

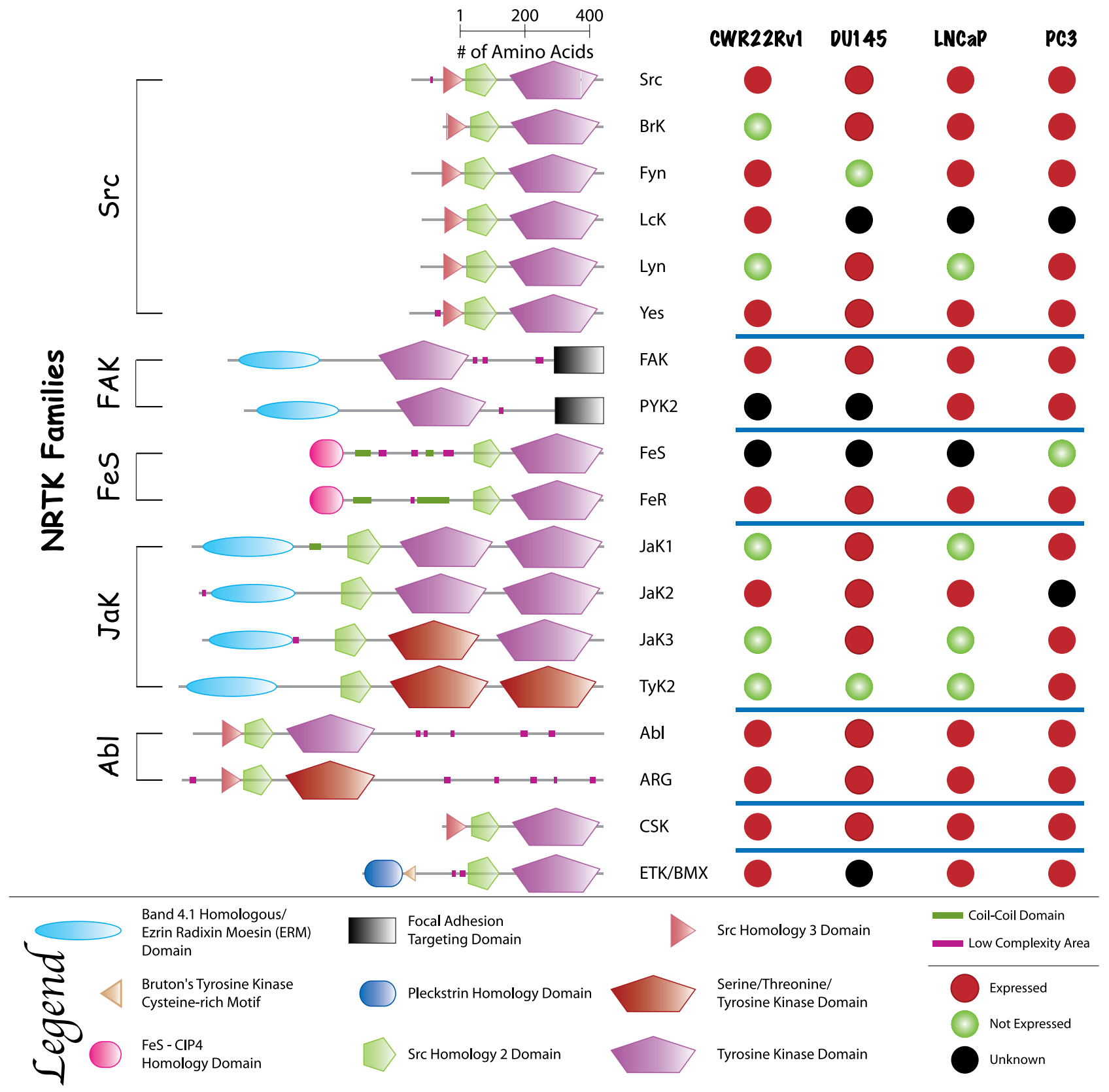

Figure 2. Summary of NRTK mRNA or protein expression in CWR22Rv1, DU145, LNCaP, and PC3 cell lines based on internal data and published reports. NRTK domain drawings and domain information were derived from Simple Modular Architecture Research Tool (SMART, Heidelberg, Germany). 
tyrosine kinase (BLK), breast tumor kinase/protein tyrosine kinase 6 (BrK/PTK6), Gardner-Rasheed feline sarcoma viral oncogene homolog (FGR), Fyn oncogene related to Src, FGR, Yes (Fyn), hemopoietic cell kinase (HCK), LcK, v-Yes-1 Yamaguchi sarcoma viral-related oncogene homolog (Lyn), Src, Src-related kinase lacking C-terminal regulatory tyrosine and N-terminal myristoylation sites (SRMS), Yes, and Yes-related kinase (YRK). Of these, FGR, Fyn, LcK, Lyn, Src, and Yes are expressed in either CaP tumor samples or cell lines. Src, FGR, Fyn, LcK, and Lyn in particular have been the most widely studied in CaP.

Src The premier member of its namesake family, Src is extensively studied in cancer biology. Less is known, however, about Src biology in CaP. Though there are no published reports of Src expression or activation levels in clinical CaP specimens, Src is implicated in CaP through its association with factors that correlate positively with the presence or the progression of $\mathrm{CaP}$ disease, such as protein kinase $\mathrm{C}(\mathrm{PKC}) \varepsilon$, endothelial-derived gene 1 (EG-1), and a truncated form of c-kit [23-25]. As further evidence of Src's possible involvement in CaP, DRS, a negative Src regulator, is down-regulated in $\mathrm{CaP}$ tissues and in prostate intraepithelial neoplasia relative to normal and benign prostate hyperplasia (BPH) tissues [26]. Thus, there is circumstantial clinical evidence that Src plays a role in $\mathrm{CaP}$ through its interactions with other factors of significance in CaP.

More is known about Src in CaP in vitro. Src is expressed in commonly used CaP cell lines CWR22Rv1, DU145, LAPC-4, LNCaP, and PC-3 (Figure 3). At first glance, Src protein expression levels in $\mathrm{CaP}$ cell lines do not positively correlate with the aggressiveness, Al state, or the proliferation rates of these cell lines. It is important to note, however, that wild-type cellular Src is not normally constitutively active. Its main role is to transduce signals of upstream activators. In cancer, the upstream signals may be aberrant, thus leading to improper activation of Src and its downstream pathways. One such pathway in $\mathrm{CaP}$ is Src activation by neuroendocrine ligands [27].

Neuroendocrine differentiation in $\mathrm{CaP}$ is theorized to be in part responsible for the development of $\mathrm{Al} \mathrm{CaP}$ through the secretion of neuroendocrine ligands. There is evidence that

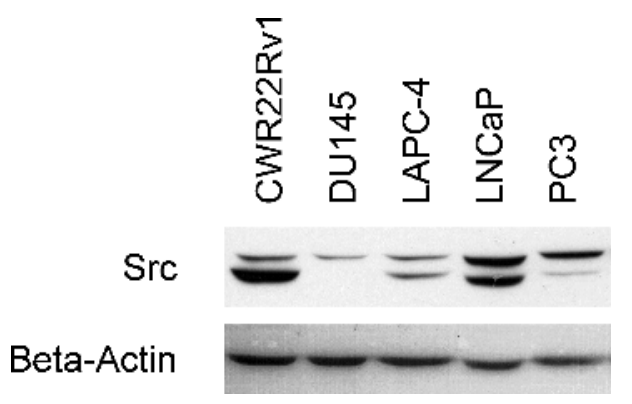

Figure 3. Western blot analysis of total Src protein expression levels in prostate cancer cell lines. Src is shown as a doublet upon probing in most cell lines. Internal overexpression data (not shown) indicate that both bands are Src and that the doublet is not a result of nonspecific probing of other Src family kinase members.
Src takes part in AI cell proliferation. Cyclic adenosine monophosphate (cAMP) analogs are able to activate Src following neuroendocrine differentiation, perhaps secondary to secreted neuroendocrine factors such as gastrin-releasing peptide and lysophosphatidic acid (LPA) [28-31]. LPA is thought to promote cell proliferation through the $v$-Ha-ras Harvey rat sarcoma viral oncogene homolog (Ras)-v-raf-1 murine leukemia viral oncogene homolog 1 (Raf)-ERK1/2 pathway in Src-dependent fashion. Bombesin, a Xenopus gastrin-releasing peptide homolog, can also activate ERK1/2 through Src, possibly through epidermal growth factor (EGF) receptor transactivation [32]. Once ERK1/2 has been activated, it can then activate the androgen receptor $(A R)$ in an Al manner, which promotes cell growth [27,33]. In addition to LPA and bombesin, non-neurotrophic factors such as interleukin-8 (IL-8) and insulin-like growth factor-1 (IGF-1) also promote Al cell growth through Src [34,35].

In addition to cell proliferation, Src also takes part in antiapoptotic pathways in CaP. Bombesin, endothelin (ET1), met proto-oncogene (Met), and dihydrotestosteroneactivated AR all inhibit apoptosis through Src activation [26,36-38]. There is, however, no consensus mechanism by which Src promotes cell survival. Nuclear factor $\kappa B$ (NF-кB)-v-akt murine thymoma viral oncogene homolog 1 (Akt)-p21-associated kinase 1 (PAK1) pathway, MEK1/2ERK1/2-CREB pathway, and signal and transducer of transcription 3 (STAT3)-dependent down-regulation of B-cell lymphoma leukemia (BCL-xL) and myeloid cell leukemia sequence 1 (MCL-1) are all pathways by which Src inhibits apoptosis [39].

Src is involved in other aspects of CaP biology: cell migration and adhesion. Src interacts with the extracellular signals through the IL-8 receptor, Met, $\beta_{1}$ integrins, Kangai 1/cluster designation 82 (KAI1/CD82), and CD44 [23,34,40,41]. CD44 is a cell surface glycoprotein involved in cell-cell and cellmatrix adhesions. KAl1/CD82 functions as a metastasis suppressor, disrupting integrin-induced Src activation [42]. Intracellularly, Src modulates cell migration and adhesion through its interaction with FAK and p130 CRK-associated substrate (p130CAS) [2].

In addition to cell migration, Src also assists in tumor invasion through its regulation of matrix metalloproteinases (MMPs). MMPs aid in invasion through the degradation of the extracellular matrix. Bombesin promotes Src-dependent tumor progression and metastasis through the activation of MMP9 in conjunction with $\beta_{1}$ integrins [43]. Src inhibition, on the other hand, decreases MMP9 activity levels [2,44].

Induction of angiogenesis by malignant cells is required for continued cell proliferation and metastasis, and vascular endothelial growth factor (VEGF) is a critical angiogenic factor. Src participates in angiogenesis in $\mathrm{CaP}$ through the JaK1-STAT3-VEGF pathway [45]. Src activation is also required for VEGF expression in simulated hypoxia environment through increased levels of hypoxia-inducible factor $1 \alpha$ (HIF-1 $\alpha)$ and activation of STAT3; as additional evidence of Src's involvement in angiogenesis, overexpression of active Src leads to increased VEGF expression [46]. Expression of the melanoma-differentiation-associated gene-7, a Src 
inhibitor, on the other hand, inhibits the subsequent downstream STAT3-VEGF pathway $[46,47]$.

$\mathrm{Src}$ is also of particular interest in $\mathrm{CaP}$ in part because of its interaction with steroid receptors. There is evidence that low amounts of AR and androgen lead to Src activation in the cytoplasm, thereby triggering downstream signaling events independent of AR's transcriptional and DNA-binding activity $[38,48]$. In fact, dominant negative Src can inhibit DNA synthesis following stimulation with low amounts of synthetic androgen. AR overexpression and higher concentrations of androgen, however, seem to bypass the Src pathway, leading to AR translocation to the nucleus and ARtranscriptional activity-based DNA synthesis.

In addition to the aforementioned activation of Src by androgen-activated AR, Src also associates with $A R$ and estrogen receptor (ER) upon stimulation with estradiol, ultimately resulting in increased cell proliferation $[38,49,50]$. It is thought that Src serves as a scaffolding protein for the AR-ER complex. Steroidal ligand, however, is not necessary for AR-Src complex formation. Upon EGF stimulation, preformed heterodimers of $\mathrm{ER} \alpha$ and AR form a complex with EGF receptor and Src, resulting in the activation and phosphorylation of EGF receptor, DNA synthesis, and cytoskeletal changes [51]. On the other hand, DOC-2/DAB2, a tumor suppressor and a negative Src regulator protein, is reported to inhibit AR's mitotic effects through the disruption of the AR-Src complex $[52,53]$. Thus, taken together with reports of AI AR activation by Src, AR and Src seem to be able to reciprocally transactivate, depending on the concentration and type of stimulatory ligand.

There are few published reports on cellular elements that negatively regulate $\mathrm{Src}$ in $\mathrm{CaP}$. In addition to DOC-2/ DAB2, tumor growth factor (TGF) $\beta$ is reported to decrease both Src expression and its corresponding activity. This is shown by the accumulation of unphosphorylated form of $\mathrm{SH} 2$-containing protein (SHC) and a subsequent decrease in complex formation between $\mathrm{SHC}$ and growth factor receptor-bound protein 2 (Grb2) [54].

BrK/PTK6 BrK is an Src family member, and little is known about it in CaP. In patient samples, BrK is detected in the nuclei of normal luminal epithelial tissues and welldifferentiated tumors, but not in poorly differentiated tumors [55]. Localization of BrK in CaP cell lines LNCaP, which is poorly tumorigenic, and PC-3, which is more aggressive, is primarily nuclear and cytoplasmic, respectively. Though PC-3 expressed more BrK than LNCaP did, BrK is less active in PC-3 cells. Thus, the localization of BrK may play a role in the differentiation of $\mathrm{CaP}$ and its aggressiveness.

FGR/Src-2 FGR is an Src kinase family member. It is a negative regulator of phosphatase and tensin homolog (PTEN) and a positive regulator of both Ras and Raf1, thus inhibiting apoptosis and stimulating cell growth, respectively [56]. Though little is known about FGR in CaP, FGR may be overexpressed in CaP, as shown by FGR DNA amplification in patient tumor tissues transitioning from androgen- dependent to Al states [56]. Thus, FGR may play a role in CaP growth and survival.

Fyn Fyn is an Src family kinase member. It is involved in LNCaP mitogenesis following prolactin stimulation [57]. Though it is suggested that Fyn participates in prolactininduced cell proliferation through $\mathrm{K}^{+}$ion channels, further studies are necessary in order to elucidate the mechanism of Fyn-modulated prolactin-induced cell proliferation in CaP.

LcK LcK is an Src family kinase member. It is expressed in CWR22 xenograft cells [3]. Little else is known about the role of LcK in CaP.

Lyn Lyn is an Src family kinase member expressed in normal prostate, $95 \%$ of primary $\mathrm{CaP}$, and $\mathrm{Al} \mathrm{PC}-3$ and DU145 cells [58]. Lyn knockout mice have abnormal prostate gland development. Treatment with KRX-123, a Lyn-specific inhibitor, results in the inhibition of cell growth in DU145 and PC-3 cell lines. DU145 explants in mice treated with $\mathrm{KRX}-123$ were found to also undergo apoptosis. Thus, Lyn seems to play a role in the proliferation and the apoptosis of CaP.

Lyn may also be an important regulator of cell migration in CaP. DU145 cells treated with dasatinib, an Src family kinase inhibitor, have reduced migratory activity [2]. On the other hand, Lyn can bind with neutral endopeptidase (NEP) and act as a competitive inhibitor to the PI3K-FAK complex, resulting in decreased cell migration [59]. Lyn's role in CaP cell migration is therefore inconclusive.

In $\mathrm{CaP}$, Lyn is down-regulated by TGF $\beta$ and up-regulated by KAI1/CD82 [54,60]. Despite its elevated expression following KAI1/CD82 stimulation, however, Lyn's overall kinase activity was unchanged.

\section{FAK Family}

FAK As the predominate member of its namesake family of kinases, FAK is well studied in CaP. Several general reviews of FAK are available [61-71]. Though FAK may play roles in growth, apoptosis, and angiogenesis in CaP, FAK is known primarily for its role in cell motility and cytoskeletal rearrangement, as supported by in vivo and in vitro evidence. In clinical specimens, FAK expression and activation are uniformly higher in metastatic $\mathrm{CaP}$ than in normal and $\mathrm{BPH}$ tissues [72,73]. In vitro comparison between highly metastatic $\mathrm{CaP}$ cell lines and LNCaP, a cell line with lower metastatic potential, shows similar results, with increased expression and activation of FAK in the more aggressive cell lines [74]. FAK's association with molecular mediators of cell migration and adhesions are indicative of its function as well. Activated FAK complexes with $\beta_{1}$ and $\alpha(v) \beta_{3}$ integrins, molecules involved in cell adhesion [75-78]. As further evidence of FAK's function as a cell motility factor, inhibition of FAK with anti-FAK (pY397) antibody or FAK-related nonkinase (FRNK) resulted in significantly decreased cell migration [79].

Bombesin and IL-8 are both G protein-coupled receptors (GPCR) that activate FAK and stimulate cell migration 
[34,79-81]. This is not surprising given FAK's reciprocal transactivation relationship with Src and both IL-8 and bombesin's abilities to activate Src. For bombesin to activate FAK, however, both PKC and an intact cytoskeleton are required $[80,82]$. Following its activation, FAK then phosphorylates p130CAS, leading to p130CAS-v-crk avian sarcoma virus CT10 oncogene homolog (CRKII) complex formation. Disruption of the p130CAS-CRKII complex by overexpressing KAI1/CD82 results in decreased cell motility [60].

Extracellularly, FAK is activated by integrins, ET1, bombesin, IL-8, and urokinase plasminogen activator (UPA), an invasion and metastasis factor in $\mathrm{CaP}[83,84]$. Intracellularly, it is modulated by Src. It is important to note that Src and FAK activation often go hand in hand. They couple and reciprocally transactivate each other. There are, however, exceptions. FAK activation by autophosphorylation of tyrosine 397 is not Src-dependent; it is adhesion-dependent [74]. On the other hand, phosphorylation of tyrosine 861, which leads to increased FAK activity, is Src-dependent but not adhesion-dependent.

Though FAK is primarily a cell motility regulator, it is also involved in cell proliferation. Similar to cell migration, bombesin-induced FAK-mediated proliferation requires an intact cytoskeleton [80]. A signal downstream of FAK is ETK/BMX, an NRTK critical for bombesin-induced growth [27]. Following FAK activation of ETK/BMX, ETK/BMX subsequently activates $A R$, thereby inducing cell growth. Interestingly, not only can FAK indirectly activate $A R$, it can also be activated by membrane-associated AR in a PI3Kdependent manner [85].

In addition to migration and proliferation, FAK may also be involved in CaP angiogenesis and apoptosis. There is evidence that FAK induces VEGF transcription in an ERK1/ 2-dependent, Rap1-dependent, and Raf-dependent but Ras-independent manner [86]. Increased VEGF transcription may then lead to an increased level of its secreted protein and, thus, angiogenesis. In regard to apoptosis, treatment of cells with proapoptotic factors FTY720 and doxazosin both down-regulate FAK expression for reasons that are not currently known $[87,88]$.

There are few known ways in which FAK is negatively regulated in CaP. Negative FAK regulators include PTEN, a tumor suppressor gene with dual phosphatase activity that is frequently deleted in aggressive CaP [89]. FAK may also be indirectly negatively regulated through the formation of the Lyn-PI3K-NEP complex instead of the PI3KFAK complex [59].

Proline-rich tyrosine kinase 2/cell adhesion kinase $\beta$ (PYK2/ $C A K \beta) \quad P Y K 2 / C A K \beta$ is a member of the FAK family of tyrosine kinases. A general review of PYK2 is available [90]. It is expressed in normal prostate epithelia and $\mathrm{BPH}$, but its expression level decreases with increasing grade in $\mathrm{CaP}$ [91]. The gene is located on chromosome 8p21.1, a site of frequent deletion in $\mathrm{CaP}$ [92].

Though in vivo evidence suggests that PYK2 plays a tumor suppressive role in $\mathrm{CaP}$, the in vitro evidence of this hypothesis is inconclusive. In vitro experiments show that
PYK2 is activated by LPA and tumor necrosis factor $\alpha$. PYK2 plays a role in the activation of ERK1/2 following LPA stimulation and may thus stimulate cell proliferation [93]. In addition, cells expressing dominant negative PYK2 have decreased proliferation rates. On the other hand, PYK2 indirectly inhibits AR activation through the inactivation of an AR-associated protein, ARA55 [94]. Thus, PYK2's role in CaP may depend on the androgen sensitivity status of the cells in question and requires further investigation and clarification.

\section{FeS Family}

The FeS family of NRTKs consists of two members: FeS/ $\mathrm{FpS}$ and $\mathrm{FpS} / \mathrm{FeS}$-related tyrosine kinase (FeR). Little is known about the FeS family in $\mathrm{CaP}$. An examination of $\mathrm{CaP}$ cell lines PC-3, PC133, and PC135 failed to detect FeS transcript [95]. FeR expression, on the other hand, was found in $\mathrm{CaP}$ cell lines PC-3, DU145, and LNCaP and positively correlated with $\mathrm{CaP}$ versus normal and $\mathrm{BPH}$ tissue samples [96]. Consistent with patient sample data, cells transfected with antisense FeR grew at a slower rate and were unable to grow in an anchorage-independent fashion. In the dog model, a higher FeR expression was found in dividing versus resting prostate epithelial cells and in cells displaying basal cell hyperplasia and metaplasia following postcastration estrogen treatment [96]. Thus, FeR is likely a proliferation factor in $\mathrm{CaP}$.

\section{JaK Family}

JaK1 The JaK family of kinases is well known for its role in signaling events in cells following cytokine stimulation and its association with the STAT family of kinases. Though JaK1 is present in some clinical CaP specimens, JaK1 is reported to be either negatively regulated or mutated in many CaP cell lines $[4,97,98]$. LNCaP is found to have both nonsense mutation and repressed JaK1 transcription whereas CWR22Rv1 and LAPC-4 have only nonsense mutations and no known transcriptional repression.

In DU145 cells, which have wild-type JaK1, there are reports that JaK1 associates with breast cancer susceptibility gene 1 (BRCA1) [99]. When BRCA1 is overexpressed, JaK1 and STAT3 become activated. Subsequent inhibition of STAT3 activation results in decreased cell proliferation as well as in apoptosis. Interestingly, inhibition of JaK1 in wildtype DU145 does not result in apoptosis [100]. Thus, it may be possible that although JaK1 activation by BRCA1 leads to increased JaK1 and STAT3 activation, STAT3 may in fact not be directly downstream of JaK1 in $\mathrm{CaP}$, and their concurrent activation is coincidental.

JaK1 may also play a role in the inhibition of CaP migration and invasion following IL-10 stimulation [101]. Tissue inhibitor of metalloproteinases (TIMP) 1 is an anti-invasion factor. IL-10 is known to activate the JaK1-IL-10E1-TIMP-1 pathway in $\mathrm{CaP}$ [102].

JaK2 JaK2 is expressed in some CaP tissues [4]. Similar to JaK1, JaK2 is also activated by BRCA1 in DU145 cells [99]. It 
is interesting to note that although JaK1 inhibition does not result in apoptosis in wild-type DU145 cells, inhibition of JaK2 does [100]. Thus, STAT3 activation in DU145 may be dependent on JaK2 rather than on JaK1. Whether STAT3 is activated by JaK1 or JaK2 in CaP, however, seems to be cell line-dependent [103].

JaK2 may also be involved in cell proliferation in CaP. Tyrosine kinase inhibitor peptide (TKIP) directly inhibits JaK2 autophosphorylation, decreases STAT3 activation, and slows CaP proliferation [104]. Consistent with decreased cell proliferation and STAT3 activation, cyclin D1 level is decreased and cells are arrested in the $\mathrm{G}_{1}$ phase of the cell cycle following TKIP treatment. Thus, JaK2 may be important for $\mathrm{CaP}$ growth through the STAT3 pathway. In addition to STAT3, JaK2 may be of particular importance in CaP through its regulation of STAT5, a factor that positively correlates with the histological grade of $\mathrm{CaP}[105,106]$.

TyK2 TyK2 is expressed in some CaP tissues [4]. Though TyK2 may also be involved in CaP migration and invasion and similarly participates in the activation of IL-10E1 following IL-10 stimulation of CaP cells as JaK1, its temporal regulation profile is different from that of JaK1 $[101,102]$.

\section{Members of Other NRTK Families}

$\mathrm{Abl} \quad \mathrm{Abl}$ is well known for its role in the etiology of $\mathrm{CML}$ following the formation of the Philadelphia chromosome $(\mathrm{t}(9: 22))$ and the breakpoint cluster region (Bcr)-Abl hybrid gene product. Less is known, however, about Abl in CaP. It is known that $\mathrm{Abl}$ is expressed in some $\mathrm{CaP}$ specimens and that $\mathrm{Abl}$ is necessary for retinoblastoma-mediated $\gamma$ radiation-induced apoptosis in DU145 cells [4,107]. There is indirect evidence that Abl may be important in CaP. Human spectrin SH domain-binding protein 1 (Hssh3bp1) is a gene that binds to Abl, possibly as a negative regulator [108]. A majority (9 of 17) of $\mathrm{CaP}$ tumor samples analyzed failed to express Hssh3bp1. Furthermore, Hssh3bp1 is found on chromosome 10p, a region frequently deleted in CaP. Thus, Abl may be circumstantially implicated in $\mathrm{CaP}$ through its association with Hssh3bp1.

Imatinib mesylate (Gleevec; Novartis, East Hanover, NJ) is a $\mathrm{Bcr}-\mathrm{Abl}$ inhibitor that is clinically used for the treatment of CML. It also has activity against Kit kinase and plateletderived growth factor (PDGF) receptor. In vitro, Gleevec inhibits $\mathrm{CaP}$ cell growth with $\mathrm{IC}_{50}$ in the $10-\mu \mathrm{M}$ range [109]. In mice models, however, Gleevec's efficacy against CaP growth is inconclusive with some, but not all, studies showing growth inhibition [110-113].

Similarly, preliminary results from clinical studies also paint a mixed picture. A phase I clinical trial of Gleevec in combination with docetaxel in $\mathrm{Al} \mathrm{CaP}$ showed a prostate-specific antigen (PSA) decline in 14 of 21 patients, although it is unknown whether the decline can be attributed to Gleevec or docetaxel [114]. In another Al CaP study, Gleevec in combination with zoledronic acid (Zometa, Novartis) showed no clinical effect in $15 \mathrm{CaP}$ patients [115]. Lastly, as monotherapy in 16 patients with androgen-sensitive CaP, Gleevec treatment resulted in nine patients with stable PSA levels and seven patients with PSA progression [116]. Thus, clinical use of Gleevec as monotherapy in CaP may be ineffective. The efficacy of using Gleevec as an adjuvant therapy to other treatment modalities is presently unknown.

CSK CSK is a well known negative Src regulator [117]. Little is directly known about CSK in CaP other than that it complexes with FAK in metastatic tumors and PC-3 cells [73].

ETK/BMX Discovered in 1994, ETK/BMX belongs to the Tec family of NRTK [118]. In CaP, ETK is downstream of $\mathrm{PI3K}$ in the induction of the neuroendocrine differentiation of LNCaP cells following IL-6 stimulation [119]. It is also reported to function as an antiapoptotic factor. Overexpression of ETK confers resistance to apoptosis in $\mathrm{CaP}$ cells through its interaction with PI3K [120]. PI3K is not, however, required for ETK activation [27]. Another mechanism by which ETK may protect against apoptosis is through its interaction with p53 [121]. Interestingly, ETK also participates in the apoptotic cascade in CaP cells. Introduction of ETK's C-terminal fragment into PC-3 cells can lead to apoptosis following proteolytic cleavage of ETK by caspases [122].

ETK is also critical for cell proliferation following bombesin stimulation and AR activation in CaP [27]. ETK serves as a signal transducer between Src and FAK upstream and AR downstream. ETK alone, however, is insufficient for AR activation. ETK must be able to reciprocally transactivate with Pim1 before AR activation [123,124].

Other NRTKS SYK and TNK1 are other NRTKs that have been studied in CaP. Virtually nothing is known about their properties and functions in prostate cancer except that the promoter region of SYK is hypermethylated and TNK1 transcript is found in prostate tissues $[125,126]$. SYK expression may thus be down-regulated in $\mathrm{CaP}$, whereas TNK1 protein expression level remains to be investigated.

\section{Conclusion}

Much is known regarding specific NRTKs in CaP (Src, FAK, JaK1/2, and ETK), whereas less is known about the other NRTKs. Perhaps it is not a coincidence that the well-studied Src, FAK, JaK1/2, and ETK kinases are involved in processes indispensable to the pathology of $\mathrm{CaP}$ : cell growth, migration, invasion, angiogenesis, and apoptosis. It is therefore imperative that we learn more about these NRTKs through future studies. Although Src, FAK, JaK1/2, and ETK are important in $\mathrm{CaP}$ biology, we should not neglect the other NRTKs that may also play important roles in $\mathrm{CaP}$ and should also investigate the lesser known NRTKs.

Looking at the current literature of NRTKs in CaP, there emerges a picture of Src being an ubiquitous player in multiple biological processes interacting with numerous players in multiple signaling pathways. Src transduces signals from upstream receptors such as IL-8, EGF, IGF-1, neurotensin, ET1, and HGF/SF to downstream molecules such as FAK, ETK, JAK1/2, STAT3, Ras, ERK1/2, Akt, HIF-1 $\alpha$, and, of particular significance in CaP biology, AR (Figure 4). Given 


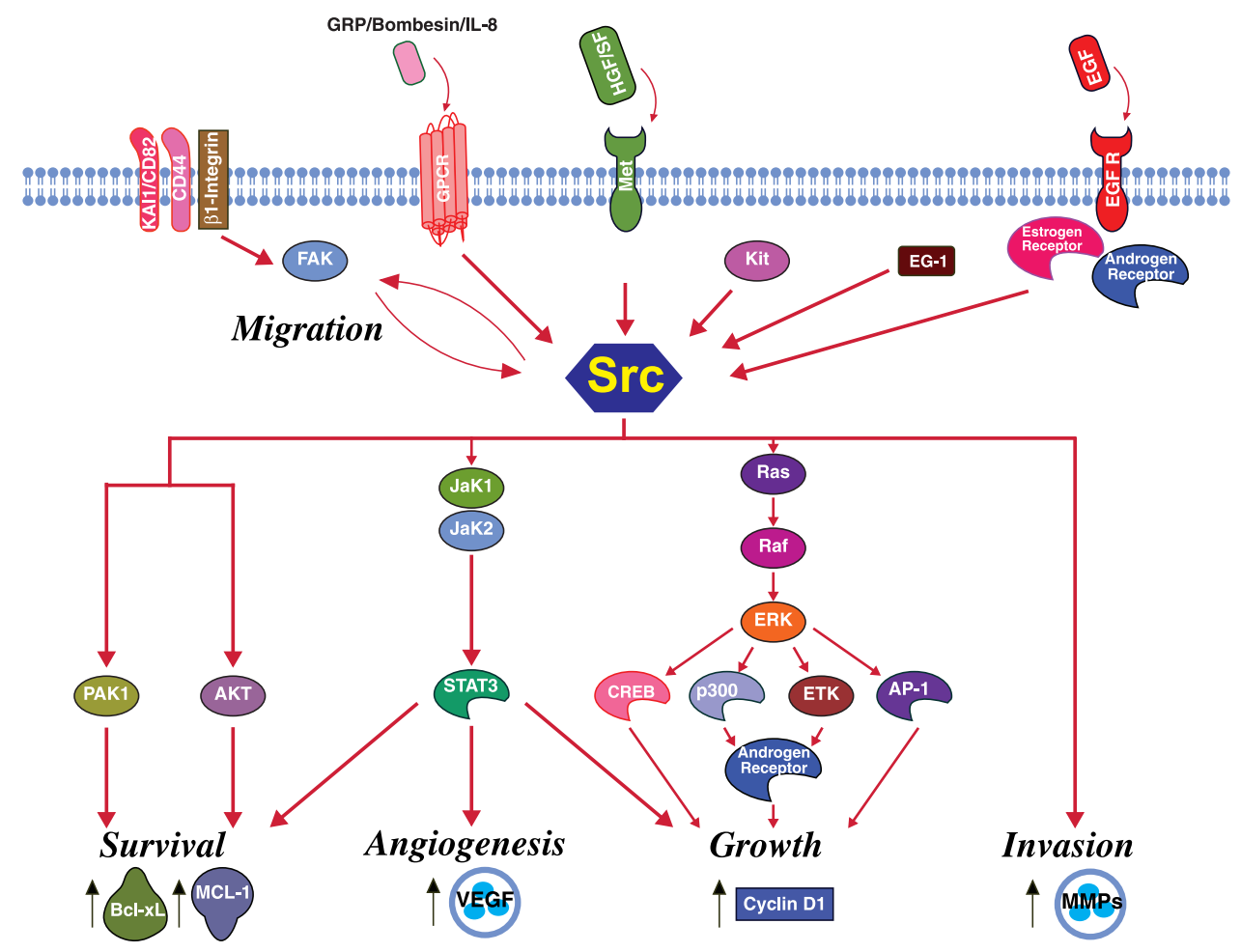

Figure 4. Known Src pathways in prostate cancer. The close proximity of molecules not connected with arrows denote physical association. Red arrows denote activation. Black arrows denote change in levels of molecule. Figure templates were provided by BioCarta (San Diego, CA).

the preponderance of evidence in multiple biological processes linking Src to CaP, Src is likely an important point of pathway convergence in CaP. Perhaps it is not surprising then that Src is currently the only NRTK target in clinical trials for CaP, whereas no NRTK-specific therapy is available for general clinical use in CaP. What remains unclear, however, is Src's relative importance in particular stages of CaP: oncogenesis, growth, survival, Al growth, angiogenesis, and metastasis. Nevertheless, with cancer treatments moving toward targeting specific pathways, it is important that we continue investigating signaling pathways so that we can develop novel therapies through continued research.

\section{References}

[1] Jemal A, Siegel R, Ward E, Murray T, Xu J, Smigal C, and Thun MJ (2006). Cancer statistics, 2006. CA Cancer J Clin 56, 106-130.

[2] Nam S, Kim D, Cheng JQ, Zhang S, Lee JH, Buettner R, Mirosevich J, Lee FY, and Jove R (2005). Action of the Src family kinase inhibitor, dasatinib (BMS-354825), on human prostate cancer cells. Cancer Res 65, 9185-9189.

[3] Robinson D, He F, Pretlow T, and Kung HJ (1996). A tyrosine kinase profile of prostate carcinoma. Proc Natl Acad Sci USA 93, 5958-5962.

[4] Moore TM, Garg R, Johnson C, Coptcoat MJ, Ridley AJ, and Morris JD (2000). PSK, a novel STE20-like kinase derived from prostatic carcinoma that activates the c-Jun $\mathrm{N}$-terminal kinase mitogen-activated protein kinase pathway and regulates actin cytoskeletal organization. $J$ Biol Chem 275, 4311-4322.

[5] Boggon TJ and Eck MJ (2004). Structure and regulation of Src family kinases. Oncogene 23, 7918-7927.

[6] Bromann PA, Korkaya H, and Courtneidge SA (2004). The interplay between Src family kinases and receptor tyrosine kinases. Oncogene 23, 7957-7968.

[7] Gauld SB and Cambier JC (2004). Src-family kinases in B-cell development and signaling. Oncogene 23, 8001-8006.
[8] Geahlen RL, Handley MD, and Harrison ML (2004). Molecular interdiction of Src-family kinase signaling in hematopoietic cells. Oncogene 23, 8024-8032.

[9] Kalia LV, Gingrich JR, and Salter MW (2004). Src in synaptic transmission and plasticity. Oncogene 23, 8007-8016.

[10] Luttrell DK and Luttrell LM (2004). Not so strange bedfellows: Gprotein-coupled receptors and Src family kinases. Oncogene 23, $7969-7978$.

[11] Martin GS (2004). The road to Src. Oncogene 23, 7910-7917.

[12] Palacios EH and Weiss A (2004). Function of the Src-family kinases, Lck and Fyn, in T-cell development and activation. Oncogene 23, 7990-8000.

[13] Parsons SJ and Parsons JT (2004). Src family kinases, key regulators of signal transduction. Oncogene 23, 7906-7909.

[14] Playford MP and Schaller MD (2004). The interplay between Src and integrins in normal and tumor biology. Oncogene 23, 7928-7946.

[15] Reynolds $A B$ and Roczniak-Ferguson A (2004). Emerging roles for p120-catenin in cell adhesion and cancer. Oncogene 23, 7947-7956.

[16] Shupnik MA (2004). Crosstalk between steroid receptors and the c-Src-receptor tyrosine kinase pathways: implications for cell proliferation. Oncogene 23, 7979-7989.

[17] Silva CM (2004). Role of STATs as downstream signal transducers in Src family kinase-mediated tumorigenesis. Oncogene 23, 8017-8023.

[18] Alvarez RH, Kantarjian HM, and Cortes JE (2006). The role of Src in solid and hematologic malignancies: development of new-generation Src inhibitors. Cancer 107, 1918-1929.

[19] Trevino JG, Summy JM, and Gallick GE (2006). SRC inhibitors as potential therapeutic agents for human cancers. Mini Rev Med Chem 6, 681-687.

[20] Summy JM and Gallick GE (2006). Treatment for advanced tumors: SRC reclaims center stage. Clin Cancer Res 12, 1398-1401.

[21] Alper O and Bowden ET (2005). Novel insights into c-Src. Curr Pharm Des 11, 1119-1130.

[22] Roskoski R Jr (2005). Src kinase regulation by phosphorylation and dephosphorylation. Biochem Biophys Res Commun 331, 1-14.

[23] Wu D, Thakore CU, Wescott GG, McCubrey JA, and Terrian DM (2004). Integrin signaling links protein kinase $C$ epsilon to the protein kinase B/Akt survival pathway in recurrent prostate cancer cells. Oncogene 23, 8659-8672.

[24] Paronetto MP, Farini D, Sammarco I, Maturo G, Vespasiani G, Geremia R, Rossi P, and Sette C (2004). Expression of a truncated 
form of the c-Kit tyrosine kinase receptor and activation of Src kinase in human prostatic cancer. Am J Pathol 164, 1243-1251.

[25] Lu M, Zhang L, Maul RS, Sartippour MR, Norris A, Whitelegge J, Rao JY, and Brooks MN (2005). The novel gene EG-1 stimulates cellular proliferation. Cancer Res 65, 6159-6166.

[26] Kim CJ, Shimakage M, Kushima R, Mukaisho K, Shinka T, Okada Y, and Inoue $\mathrm{H}$ (2003). Down-regulation of drs mRNA in human prostate carcinomas. Hum Pathol 34, 654-657.

[27] Lee LF, Guan J, Qiu Y, and Kung HJ (2001). Neuropeptide-induced androgen independence in prostate cancer cells: roles of nonreceptor tyrosine kinases Etk/Bmx, Src, and focal adhesion kinase. Mol Cell Biol 21, 8385-8397.

[28] Allard P, Beaulieu P, Aprikian A, and Chevalier S (2000). Bombesin modulates the association of Src with a nuclear 110-kd protein expressed in dividing prostate cells. J Androl 21, 367-375.

[29] Daaka Y (2002). Mitogenic action of LPA in prostate. Biochim Biophys Acta 1582, 265-269.

[30] Kue PF and Daaka Y (2000). Essential role for G proteins in prostate cancer cell growth and signaling. J Urol 164, 2162-2167.

[31] Bang YJ, Pirnia F, Fang WG, Kang WK, Sartor O, Whitesell L, Ha MJ, Tsokos M, Sheahan MD, Nguyen P, et al. (1994). Terminal neuroendocrine differentiation of human prostate carcinoma cells in response to increased intracellular cyclic AMP. Proc Natl Acad Sci USA 91, 5330-5334.

[32] Xiao D, Qu X, and Weber HC (2003). Activation of extracellular signal-regulated kinase mediates bombesin-induced mitogenic responses in prostate cancer cells. Cell Signal 15, 945-953.

[33] Gong J, Zhu J, Goodman OB, Pestell RG, Schlegel PN, Nanus DM, and Shen R (2006). Activation of p300 histone acetyltransferase activity and acetylation of the androgen receptor by bombesin in prostate cancer cells. Oncogene.

[34] Lee LF, Louie MC, Desai SJ, Yang J, Chen HW, Evans CP, and Kung HJ (2004). Interleukin-8 confers androgen-independent growth and migration of LNCaP: differential effects of tyrosine kinases Src and FAK. Oncogene 23, 2197-2205.

[35] Pandini G, Mineo R, Frasca F, Roberts CT Jr, Marcelli M, Vigneri R, and Belfiore A (2005). Androgens up-regulate the insulin-like growth factor-I receptor in prostate cancer cells. Cancer Res 65, 1849-1857.

[36] Fan S, Gao M, Meng Q, Laterra JJ, Symons MH, Coniglio S, Pestell RG, Goldberg ID, and Rosen EM (2005). Role of NF-kappaB signaling in hepatocyte growth factor/scatter factor-mediated cell protection. Oncogene.

[37] Sumitomo M, Shen R, Goldberg JS, Dai J, Navarro D, and Nanus DM (2000). Neutral endopeptidase promotes phorbol ester-induced apoptosis in prostate cancer cells by inhibiting neuropeptide-induced protein kinase $\mathrm{C}$ delta degradation. Cancer Res 60, 6590-6596.

[38] Unni E, Sun S, Nan B, McPhaul MJ, Cheskis B, Mancini MA, and Marcelli $M$ (2004). Changes in androgen receptor nongenotropic signaling correlate with transition of LNCaP cells to androgen independence. Cancer Res 64, 7156-7168.

[39] Kotha A, Sekharam M, Cilenti L, Siddiquee K, Khaled A, Zervos AS, Carter B, Turkson J, and Jove R (2006). Resveratrol inhibits Src and Stat3 signaling and induces the apoptosis of malignant cells containing activated Stat3 protein. Mol Cancer Ther 5, 621-629.

[40] Zhu D and Bourguignon LY (1998). The ankyrin-binding domain of $\mathrm{CD} 44 \mathrm{~s}$ is involved in regulating hyaluronic acid-mediated functions and prostate tumor cell transformation. Cell Motil Cytoskelet 39 209-222.

[41] Jee B, Jin K, Hahn JH, Song HG, and Lee H (2003). Metastasissuppressor KAl1/CD82 induces homotypic aggregation of human prostate cancer cells through Src-dependent pathway. Exp Mol Med 35, 30-37.

[42] Sridhar SC and Miranti CK (2006). Tetraspanin KAl1/CD82 suppresses invasion by inhibiting integrin-dependent crosstalk with c-Met receptor and Src kinases. Oncogene 25, 2367-2378.

[43] Festuccia C, Angelucci A, Gravina G, Eleuterio E, Vicentini C, and Bologna M (2002). Bombesin-dependent pro-MMP-9 activation in prostatic cancer cells requires beta ${ }_{1}$ integrin engagement. Exp Cell Res 280, 1-11.

[44] Recchia I, Rucci N, Festuccia C, Bologna M, MacKay AR, Migliaccio S, Longo M, Susa M, Fabbro D, and Teti A (2003). Pyrrolopyrimidine c-Src inhibitors reduce growth, adhesion, motility and invasion of prostate cancer cells in vitro. Eur J Cancer 39, 1927-1935.

[45] Nam S, Buettner R, Turkson J, Kim D, Cheng JQ, Muehlbeyer S, Hippe F, Vatter S, Merz KH, Eisenbrand G, et al. (2005). Indirubin derivatives inhibit Stat3 signaling and induce apoptosis in human cancer cells. Proc Natl Acad Sci USA 102, 5998-6003.
[46] Gray MJ, Zhang J, Ellis LM, Semenza GL, Evans DB, Watowich SS, and Gallick GE (2005). HIF-1alpha, STAT3, CBP/p300 and Ref-1/APE are components of a transcriptional complex that regulates Srcdependent hypoxia-induced expression of VEGF in pancreatic and prostate carcinomas. Oncogene 24, 3110-3120.

[47] Inoue S, Branch CD, Gallick GE, Chada S, and Ramesh R (2005). Inhibition of Src kinase activity by Ad-mda7 suppresses vascular endothelial growth factor expression in prostate carcinoma cells. Mol Ther 12, 707-715.

[48] Castoria G, Lombardi M, Barone MV, Bilancio A, Di Domenico M, De Falco A, Varricchio L, Bottero D, Nanayakkara M, Migliaccio A, et al. (2004). Rapid signalling pathway activation by androgens in epithelial and stromal cells. Steroids 69, 517-522.

[49] Migliaccio A, Castoria G, Di Domenico M, de Falco A, Bilancio A, Lombardi M, Barone MV, Ametrano D, Zannini MS, Abbondanza C, et al. (2000). Steroid-induced androgen receptor-oestradiol receptor beta-Src complex triggers prostate cancer cell proliferation. EMBO J 19, 5406-5417.

[50] Chieffi P, Kisslinger A, Sinisi AA, Abbondanza C, and Tramontano D (2003). 17beta-Estradiol-induced activation of ERK1/2 through endogenous androgen receptor-estradiol receptor alpha-Src complex in human prostate cells. Int J Oncol 23, 797-801.

[51] Migliaccio A, Di Domenico M, Castoria G, Nanayakkara M, Lombardi $M$, de Falco A, Bilancio A, Varricchio $L$, Ciociola $A$, and Auricchio $F$ (2005). Steroid receptor regulation of epidermal growth factor signaling through $\mathrm{Src}$ in breast and prostate cancer cells: steroid antagonist action. Cancer Res 65, 10585-10593.

[52] Zhoul J, Hernandez G, Tu SW, Huang CL, Tseng CP, and Hsieh JT (2005). The role of DOC-2/DAB2 in modulating androgen receptormediated cell growth via the nongenomic c-Src-mediated pathway in normal prostatic epithelium and cancer. Cancer Res 65, 9906-9913.

[53] Zhou J, Scholes J, and Hsieh JT (2003). Characterization of a novel negative regulator (DOC-2/DAB2) of $\mathrm{c}-\mathrm{Src}$ in normal prostatic epithelium and cancer. J Biol Chem 278, 6936-6941.

[54] Atfi A, Drobetsky E, Boissonneault M, Chapdelaine A, and Chevalier S (1994). Transforming growth factor beta down-regulates Src family protein tyrosine kinase signaling pathways. J Biol Chem 269, 30688-30693.

[55] Derry JJ, Prins GS, Ray V, and Tyner AL (2003). Altered localization and activity of the intracellular tyrosine kinase BrK/Sik in prostate tumor cells. Oncogene 22, 4212-4220.

[56] Edwards J, Krishna NS, Witton CJ, and Bartlett JM (2003). Gene amplifications associated with the development of hormone-resistant prostate cancer. Clin Cancer Res 9, 5271-5281.

[57] Van Coppenolle F, Skryma R, Ouadid-Ahidouch H, Slomianny C, Roudbaraki M, Delcourt P, Dewailly E, Humez S, Crepin A, Gourdou I, et al. (2004). Prolactin stimulates cell proliferation through a long form of prolactin receptor and $\mathrm{K}^{+}$channel activation. Biochem $\mathrm{J} 377,569-578$.

[58] Goldenberg-Furmanov M, Stein I, Pikarsky E, Rubin H, Kasem S, Wygoda M, Weinstein I, Reuveni H, and Ben-Sasson SA (2004). Lyn is a target gene for prostate cancer: sequence-based inhibition induces regression of human tumor xenografts. Cancer Res 64, 1058-1066.

[59] Sumitomo M, Shen R, Walburg M, Dai J, Geng Y, Navarro D, Boileau G, Papandreou CN, Giancotti FG, Knudsen B, et al. (2000). Neutral endopeptidase inhibits prostate cancer cell migration by blocking focal adhesion kinase signaling. J Clin Invest 106, 1399-1407.

[60] Zhang XA, He B, Zhou B, and Liu L (2003). Requirement of the p130CAS-Crk coupling for metastasis suppressor KAl1/CD82 mediated inhibition of cell migration. J Biol Chem 278, 27319-27328.

[61] Wozniak MA, Modzelewska K, Kwong L, and Keely PJ (2004). Focal adhesion regulation of cell behavior. Biochim Biophys Acta 1692, 103-119.

[62] Cohen LA and Guan JL (2005). Mechanisms of focal adhesion kinase regulation. Curr Cancer Drug Targets 5, 629-643.

[63] McLean GW, Carragher NO, Avizienyte E, Evans J, Brunton VG, and Frame MC (2005). The role of focal-adhesion kinase in cancer - a new therapeutic opportunity. Nat Rev Cancer 5, 505-515.

[64] Mitra SK, Hanson DA, and Schlaepfer DD (2005). Focal adhesion kinase: in command and control of cell motility. Nat Rev Mol Cell Biol 6, 56-68.

[65] Gabarra-Niecko V, Schaller MD, and Dunty JM (2003). FAK regulates biological processes important for the pathogenesis of cancer. Cancer Metastasis Rev 22, 359-374.

[66] Hanks SK, Ryzhova L, Shin NY, and Brabek J (2003). Focal adhesion kinase signaling activities and their implications in the control of cell survival and motility. Front Biosci 8, d982-d996. 
[67] Hauck CR, Hsia DA, and Schlaepfer DD (2002). The focal adhesion kinase-a regulator of cell migration and invasion. IUBMB Life 53, $115-119$.

[68] Hecker TP and Gladson CL (2003). Focal adhesion kinase in cancer. Front Biosci 8, s705-s714.

[69] McLean GW, Avizienyte E, and Frame MC (2003). Focal adhesion kinase as a potential target in oncology. Expert Opin Pharmacother 4, 227-234.

[70] Parsons JT (2003). Focal adhesion kinase: the first ten years. J Cell Sci 116, 1409-1416

[71] Schaller MD (2001). Biochemical signals and biological responses elicited by the focal adhesion kinase. Biochim Biophys Acta 1540, $1-21$.

[72] Rovin JD, Frierson HF Jr, Ledinh W, Parsons JT, and Adams RB (2002). Expression of focal adhesion kinase in normal and pathologic human prostate tissues. Prostate 53, 124-132.

[73] Tremblay L, Hauck W, Aprikian AG, Begin LR, Chapdelaine A, and Chevalier S (1996). Focal adhesion kinase (pp125FAK) expression, activation and association with paxillin and p50CSK in human metastatic prostate carcinoma. Int $J$ Cancer 68, 164-171.

[74] Slack JK, Adams RB, Rovin JD, Bissonette EA, Stoker CE, and Parsons JT (2001). Alterations in the focal adhesion kinase/Src signal transduction pathway correlate with increased migratory capacity of prostate carcinoma cells. Oncogene 20, 1152-1163.

[75] Bergan R, Kyle E, Nguyen P, Trepel J, Ingui C, and Neckers L (1996). Genistein-stimulated adherence of prostate cancer cells is associated with the binding of focal adhesion kinase to beta-1-integrin. Clin Exp Metastasis 14, 389-398.

[76] Zheng DQ, Woodard AS, Fornaro M, Tallini G, and Languino LR (1999). Prostatic carcinoma cell migration via alpha(v) beta $_{3}$ integrin is modulated by a focal adhesion kinase pathway. Cancer Res 59, 1655-1664.

[77] Zheng DQ, Woodard AS, Tallini G, and Languino LR (2000). Substrate specificity of alpha(v)beta(3) integrin-mediated cell migration and phosphatidylinositol 3-kinase/AKT pathway activation. J Biol Chem 275, 24565-24574.

[78] Bello-DeOcampo D, Kleinman HK, Deocampo ND, and Webber MM (2001). Laminin-1 and alpha ${ }_{6}$ beta $_{1}$ integrin regulate acinar morphogenesis of normal and malignant human prostate epithelial cells. Prostate 46, 142-153.

[79] Lacoste J, Aprikian AG, and Chevalier S (2005). Focal adhesion kinase is required for bombesin-induced prostate cancer cell motility. Mol Cell Endocrinol 235, 51-61.

[80] Duncan MD, Harmon JW, and Duncan LK (1996). Actin disruption inhibits bombesin stimulation of focal adhesion kinase (pp125FAK) in prostate carcinoma. J Surg Res 63, 359-363.

[81] Aprikian AG, Tremblay L, Han K, and Chevalier S (1997). Bombesin stimulates the motility of human prostate-carcinoma cells through tyrosine phosphorylation of focal adhesion kinase and of integrinassociated proteins. Int $J$ Cancer 72, 498-504

[82] Liu Y, Kyle E, Lieberman R, Crowell J, Kellof G, and Bergan RC (2000). Focal adhesion kinase (FAK) phosphorylation is not required for genistein-induced FAK-beta-1-integrin complex formation. Clin Exp Metastasis 18, 203-212.

[83] Margheri F, D'Alessio S, Serrati S, Pucci M, Annunziato F, Cosmi L, Liotta F, Angeli R, Angelucci A, Gravina GL, et al. (2005). Effects of blocking urokinase receptor signaling by antisense oligonucleotides in a mouse model of experimental prostate cancer bone metastases. Gene Ther.

[84] Sabbisetti V, Chigurupati S, Thomas S, and Shah G (2006). Calcitonin stimulates the secretion of urokinase-type plasminogen activator from prostate cancer cells: its possible implications on tumor cell invasion. Int J Cancer 118, 2694-2702.

[85] Papakonstanti EA, Kampa M, Castanas E, and Stournaras C (2003). A rapid, nongenomic, signaling pathway regulates the actin reorganization induced by activation of membrane testosterone receptors. Mol Endocrinol 17, 870-881.

[86] Sheta EA, Harding MA, Conaway MR, and Theodorescu D (2000). Focal adhesion kinase, Rap1, and transcriptional induction of vascular endothelial growth factor. J Natl Cancer Inst 92, 1065-1073.

[87] Permpongkosol S, Wang JD, Takahara S, Matsumiya K, Nonomura N, Nishimura K, Tsujimura A, Kongkanand A, and Okuyama A (2002). Anticarcinogenic effect of FTY720 in human prostate carcinoma DU145 cells: modulation of mitogenic signaling, FAK, cell-cycle entry and apoptosis. Int J Cancer 98, 167-172.

[88] Walden PD, Globina Y, and Nieder A (2004). Induction of anoikis by doxazosin in prostate cancer cells is associated with activation of caspase-3 and a reduction of focal adhesion kinase. Urol Res $\mathbf{3 2}$, $261-265$.

[89] Ittmann MM (1998). Chromosome 10 alterations in prostate adenocarcinoma (review). Oncol Rep 5, 1329-1335.

[90] Gelman IH (2003). Pyk 2 FAKs, any two FAKs. Cell Biol Int 27, 507-510.

[91] Stanzione R, Picascia A, Chieffi P, Imbimbo C, Palmieri A, Mirone V, Staibano S, Franco R, De Rosa G, Schlessinger J, et al. (2001). Variations of proline-rich kinase Pyk2 expression correlate with prostate cancer progression. Lab Invest 81, 51-59.

[92] Inazawa J, Sasaki H, Nagura K, Kakazu N, Abe T, and Sasaki T (1996). Precise localization of the human gene encoding cell adhesion kinase beta (CAK beta/PYK2) to chromosome 8 at p21.1 by fluorescence in situ hybridization. Hum Genet 98, 508-510.

[93] Picascia A, Stanzione R, Chieffi P, Kisslinger A, Dikic I, and Tramontano D (2002). Proline-rich tyrosine kinase 2 regulates proliferation and differentiation of prostate cells. Mol Cell Endocrinol 186, 81-87.

[94] Wang X, Yang Y, Guo X, Sampson ER, Hsu CL, Tsai MY, Yeh S, Wu G, Guo Y, and Chang C (2002). Suppression of androgen receptor transactivation by Pyk2 via interaction and phosphorylation of the ARA55 coregulator. J Biol Chem 277, 15426-15431.

[95] Rijnders AW, van der Korput JA, van Steenbrugge GJ, Romijn JC, and Trapman $\mathrm{J}$ (1985). Expression of cellular oncogenes in human prostatic carcinoma cell lines. Biochem Biophys Res Commun 132, $548-554$.

[96] Allard P, Zoubeidi A, Nguyen LT, Tessier S, Tanguay S, Chevrette M, Aprikian A, and Chevalier S (2000). Links between Fer tyrosine kinase expression levels and prostate cell proliferation. Mol Cell Endocrinol 159, 63-77.

[97] Dunn GP, Sheehan KC, Old LJ, and Schreiber RD (2005). IFN unresponsiveness in LNCaP cells due to the lack of JAK1 gene expression. Cancer Res 65, 3447-3453.

[98] Rossi MR, Hawthorn L, Platt J, Burkhardt T, Cowell JK, and lonov Y (2005). Identification of inactivating mutations in the JAK1, SYNJ2, and CLPTM1 genes in prostate cancer cells using inhibition of nonsense-mediated decay and microarray analysis. Cancer Genet Cytogenet 161, 97-103.

[99] Gao B, Shen X, Kunos G, Meng Q, Goldberg ID, Rosen EM, and Fan $S$ (2001). Constitutive activation of JAK-STAT3 signaling by BRCA1 in human prostate cancer cells. FEBS Lett 488, 179-184.

[100] Barton BE, Karras JG, Murphy TF, Barton A, and Huang HF (2004). Signal transducer and activator of transcription 3 (STAT3) activation in prostate cancer: direct STAT3 inhibition induces apoptosis in prostate cancer lines. Mol Cancer Ther 3, 11-20.

[101] Stearns ME, Wang M, Hu Y, and Garcia FU (2003). Interleukin-10 activation of the interleukin-10E1 pathway and tissue inhibitor of metalloproteinase-1 expression is enhanced by proteasome inhibitors in primary prostate tumor lines. Mol Cancer Res 1, 631-642.

[102] Wang M, Hu Y, and Stearns ME (2003). A novel IL-10 signalling mechanism regulates TIMP-1 expression in human prostate tumour cells. Br J Cancer 88, 1605-1614.

[103] Barton BE, Murphy TF, Adem P, Watson RA, Irwin RJ, and Huang HF (2001). IL-6 signaling by STAT3 participates in the change from hyperplasia to neoplasia in NRP-152 and NRP-154 rat prostatic epithelial cells. BMC Cancer 1, 19.

[104] Flowers LO, Subramaniam PS, and Johnson HM (2005). A SOCS-1 peptide mimetic inhibits both constitutive and IL- 6 induced activation of STAT3 in prostate cancer cells. Oncogene 24, 2114-2120.

[105] Li H, Ahonen TJ, Alanen K, Xie J, LeBaron MJ, Pretlow TG, Ealley EL, Zhang Y, Nurmi M, Singh B, et al. (2004). Activation of signal transducer and activator of transcription 5 in human prostate cancer is associated with high histological grade. Cancer Res 64, 4774-4782.

[106] Weiss-Messer E, Merom O, Adi A, Karry R, Bidosee M, Ber R, Kaploun A, Stein A, and Barkey RJ (2004). Growth hormone (GH) receptors in prostate cancer: gene expression in human tissues and cell lines and characterization, $\mathrm{GH}$ signaling and androgen receptor regulation in LNCaP cells. Mol Cell Endocrinol 220, 109-123.

[107] Bowen C, Birrer M, and Gelmann EP (2002). Retinoblastoma proteinmediated apoptosis after gamma-irradiation. J Biol Chem 277, 44969-44979.

[108] Macoska JA, Xu J, Ziemnicka D, Schwab TS, Rubin MA, and Kotula L (2001). Loss of expression of human spectrin src homology domain binding protein 1 is associated with 10p loss in human prostatic adenocarcinoma. Neoplasia 3, 99-104.

[109] Kubler HR, van Randenborgh H, Treiber U, Wutzler S, Battistel C, Lehmer A, Wagenpfeil S, Hartung R, and Paul R (2005). In vitro 
cytotoxic effects of imatinib in combination with anticancer drugs in human prostate cancer cell lines. Prostate 63, 385-394.

[110] Uehara H, Kim SJ, Karashima T, Shepherd DL, Fan D, Tsan R, Killion JJ, Logothetis C, Mathew P, and Fidler IJ (2003). Effects of blocking platelet-derived growth factor-receptor signaling in a mouse model of experimental prostate cancer bone metastases. J Natl Cancer Inst 95 , $458-470$.

[111] Kim SJ, Uehara H, Yazici S, Langley RR, He J, Tsan R, Fan D, Killion JJ, and Fidler IJ (2004). Simultaneous blockade of platelet-derived growth factor-receptor and epidermal growth factor-receptor signaling and systemic administration of paclitaxel as therapy for human prostate cancer metastasis in bone of nude mice. Cancer Res 64, $4201-4208$.

[112] Kim SJ, Uehara H, Yazici S, He J, Langley RR, Mathew P, Fan D, and Fidler IJ (2005). Modulation of bone microenvironment with zoledronate enhances the therapeutic effects of STI571 and paclitaxel against experimental bone metastasis of human prostate cancer. Cancer Res 65, 3707-3715.

[113] Corcoran NM and Costello AJ (2005). Combined low-dose imatinib mesylate and paclitaxel lack synergy in an experimental model of extraosseous hormone-refractory prostate cancer. BJU Int 96, 640-646.

[114] Mathew P, Thall PF, Jones D, Perez C, Bucana C, Troncoso P, Kim SJ Fidler IJ, and Logothetis C (2004). Platelet-derived growth factor receptor inhibitor imatinib mesylate and docetaxel: a modular phase I trial in androgen-independent prostate cancer. J Clin Oncol 22, 3323-3329.

[115] Tiffany NM, Wersinger EM, Garzotto M, and Beer TM (2004). Imatinib mesylate and zoledronic acid in androgen-independent prostate cancer. Urology 63, 934-939.

[116] Rao K, Goodin S, Levitt MJ, Dave N, Shih WJ, Lin Y, Capanna T, Doyle-Lindrud S, Juvidian P, and DiPaola RS (2005). A phase II trial of imatinib mesylate in patients with prostate specific antigen progression after local therapy for prostate cancer. Prostate 62, 115-122.

[117] Bjorge JD, O'Connor TJ, and Fujita DJ (1996). Activation of human pp60c-src. Biochem Cell Biol 74, 477-484.

[118] Tamagnone L, Lahtinen I, Mustonen T, Virtaneva K, Francis F, Muscatelli
F, Alitalo R, Smith Cl, Larsson C, and Alitalo K (1994). BMX, a novel nonreceptor tyrosine kinase gene of the BTK/ITK/TEC/TXK family located in chromosome Xp22.2. Oncogene 9, 3683-3688.

[119] Qiu Y, Robinson D, Pretlow TG, and Kung HJ (1998). Etk/Bmx, a tyrosine kinase with a pleckstrin-homology domain, is an effector of phosphatidylinositol 3'-kinase and is involved in interleukin 6-induced neuroendocrine differentiation of prostate cancer cells. Proc Natl Acad Sci 95, 3644-3649.

[120] Xue LY, Qiu Y, He J, Kung HJ, and Oleinick NL (1999). Etk/Bmx, a $\mathrm{PH}$-domain containing tyrosine kinase, protects prostate cancer cells from apoptosis induced by photodynamic therapy or thapsigargin. Oncogene 18, 3391-3398.

[121] Jiang T, Guo Z, Dai B, Kang M, Ann DK, Kung HJ, and Qiu Y (2004). Bi-directional regulation between tyrosine kinase Etk/BMX and tumor suppressor p53 in response to DNA damage. J Biol Chem 279, 50181-50189.

[122] Wu YM, Huang CL, Kung HJ, and Huang CY (2001). Proteolytic activation of ETK/Bmx tyrosine kinase by caspases. J Biol Chem 276, 17672-17678.

[123] Kim O, Jiang T, Xie Y, Guo Z, Chen H, and Quu Y (2004). Synergism of cytoplasmic kinases in IL6-induced ligand-independent activation of androgen receptor in prostate cancer cells. Oncogene 23, 1838-1844.

[124] Xie Y, Xu K, Dai B, Guo Z, Jiang T, Chen H, and Qiu Y (2006). The 44 kDa Pim-1 kinase directly interacts with tyrosine kinase Etk/BMX and protects human prostate cancer cells from apoptosis induced by chemotherapeutic drugs. Oncogene 25, 70-78.

[125] Wang Y, Yu Q, Cho AH, Rondeau G, Welsh J, Adamson E, Mercola D, and McClelland M (2005). Survey of differentially methylated promoters in prostate cancer cell lines. Neoplasia 7, 748-760.

[126] Hoehn GT, Stokland T, Amin S, Ramirez M, Hawkins AL, Griffin CA, Small D, and Civin Cl (1996). TnK1: a novel intracellular tyrosine kinase gene isolated from human umbilical cord blood CD $34^{+} / \mathrm{Lin}^{-} /$ CD38 ${ }^{-}$stem/progenitor cells. Oncogene 12, 903-913.

[127] Saitou N and Nei M (1987). The neighbor-joining method: a new method for reconstructing phylogenetic trees. Mol Biol Evol 4, 406-425. 


\title{
Biologic agents as adjunctive therapy for prostate cancer: a rationale for use with androgen deprivation
}

\author{
Eric C Nelson, Angelo J Cambio, Joy C Yang, Primo N Lara Jr and Christopher P Evans ${ }^{*}$
}

\section{SBMTHalis}

The prevalence of prostate cancer emphasizes the need for improved therapeutic options, particularly for metastatic disease. Current treatment includes medical or surgical castration, which initially induces apoptosis of prostate cancer cells, but ultimately an androgen-independent subpopulation emerges. In addition to a transient therapeutic effect, androgen-deprivation therapy (ADT) can initiate biochemical events that may contribute to the development of and progression to an androgenindependent state. This transition involves multiple signal transduction pathways that are accompanied by many biochemical changes resulting from ADT. These molecular events themselves are therapeutic targets and serve as a rationale for adjunctive treatment at the time of ADT.

KEYWORDS androgen-deprivation, androgen-independent, castration, hormone refractory prostate cancer, prostate cancer

\section{REVIEW CRITERIA}

A PubMed search of the English language literature from 1990 to 2006 for pertinent articles was conducted using the MeSH term "Prostate neoplasms" in conjunction with terms such as "biochemistry," "mechanism," androgen independent," "metastatic," and "treatment." The bibliographies of retrieved articles were scrutinized for additional articles. Identified concepts, biochemical factors, and treatment strategies were searched again using $\mathrm{MeSH}$ terms. Particularly relevant articles were input into Web of Science to retrieve the latest citations and articles.
ECNelson is a Urology Research Fellow, JC Yang is an Assistant Research Biologist, PN Lara Jr is Professor of Medical Oncology and CP Evans is Associate Professor and Chair of the Urology Department, University of California, Davis, CA. AJ Cambio is a Urology Resident at the University of Rochester, Rochester, NY, USA.

\section{Correspondence}

'Department of Urology, University of California, Davis Medical Center, Suite 3500, 4860 Y Streot, Sacramento, CA 95817, USA

christopher.evanswucdmc.ucdavis.edu

\section{Received 14 September 2006 Accepted 15 November 2006}

wwwnature.com/clinicalpractice

dol:10.1038/ncpuro0700

\section{INTRODUCTION}

Prostate cancer remains the most common noncutaneous malignancy in the US and is predicted to be the third leading cause of cancer mortality in 2006. ${ }^{1}$ Currently, androgendeprivation therapy (ADT) is the mainstay of therapy for metastatic disease and is principally palliative in nature. ADT removes androgen stimulation, initially inducing apoptotic involution of prostatic tissue. The disease, however, eventually progresses to an androgenindependent state, which is associated with a lifeexpectancy of approximately 15-20 months. ${ }^{2}$ Despite research efforts and recent advances using chemotherapeutic agents, minimal progress has been made in the treatment of advanced prostate cancer in the last 50 years, and the life expectancy of patients with metastatic disease has changed very little. ADT, while extending length and quality of life for many patients, induces biological changes in prostate cancer cells that promote an androgen-independent state.

When prostate cancer becomes androgen independent, methods of growth stimulation other than those mediated by androgens dominate, allowing progression of the disease. The androgen receptor (AR) continues to be expressed and even amplified in androgenindependent prostate cancer, and androgen responsive genes are re-expressed when cancer progresses to the androgen-independent state. ${ }^{3}$ As such, much research has focused on the AR in order to understand the method of continued AR-stimulated transcription in the absence of a natural ligand. Many possible pathways have been explored. AR amplification, mutation, and hypersensitivity might allow continued signaling with low androgen levels. Alternate pathways might activate the AR by phosphorylation in an androgen-independent manner. Finally, pathways that regulate apoptosis and cell proliferation, but without direct AR effects, might oppose the effects of ADT. The current understanding of possible mechanisms involved in the development of 
androgen-independent prostate cancer has been the subject of two reviews. 4,5

This paper focuses on the mechanisms activated or upregulated with ADT that currently show potential as targets for treatment for advanced prostate cancer and have a theoretical rationale for castration-adjunctive therapy. We summarize selected pathways and therapies, dividing our discussion into AR-dependent and AR-independent categories (Figure 1).

\section{ANDROGEN-RECEPTOR-DEPENDENT PATHWAYS}

\section{Androgen-receptor cofactors}

Activity of the AR is modulated by many cofactors that can increase or decrease its transcriptional activity. ${ }^{6}$ Coactivators permit receptor activation with the very low levels of androgen typically seen in the castrate setting, or facilitate greater AR activity with aberrant stimulation from a number of pathways (outlined below). ${ }^{4}$ Several families of cofactors have been shown to change expression levels in response to ADT (Table 1), indicating a mechanism for the development of androgen-independent disease. Feldman and Feldman ${ }^{4}$ speculate that loss of corepressors might be another mechanism for AR activation. We are not aware of any current therapy aimed at increasing corepressors or decreasing coactivators of the AR. The consistency of the castration-induced changes and strength of the effects of these proteins in preclinical studies, however, indicate that they might be targets for novel therapies in the future. ${ }^{7}$

\section{Growth factors}

Growth factors are the major paracrine signaling mechanism used by the prostatic stroma and neuroendocrine cells. In healthy prostate glands, growth factors regulate growth and cellular maturation. In the setting of androgen-independent tumors, growth factors influence an alternate pathway that activates AR-mediated signaling. In general, growth factors and neuropeptides bind cell membrane receptors, which either polymerize to activate intracellular tyrosine kinase domains, or activate associated $\mathrm{G}$-proteins that in turn activate nonreceptor tyrosine kinases (Figure 2).

One of the best characterized growth factors is the epidermal growth factor (EGF) family including transforming growth factor $a(\mathrm{TGFa})$, EGF, amphiregulin and others. These bind the

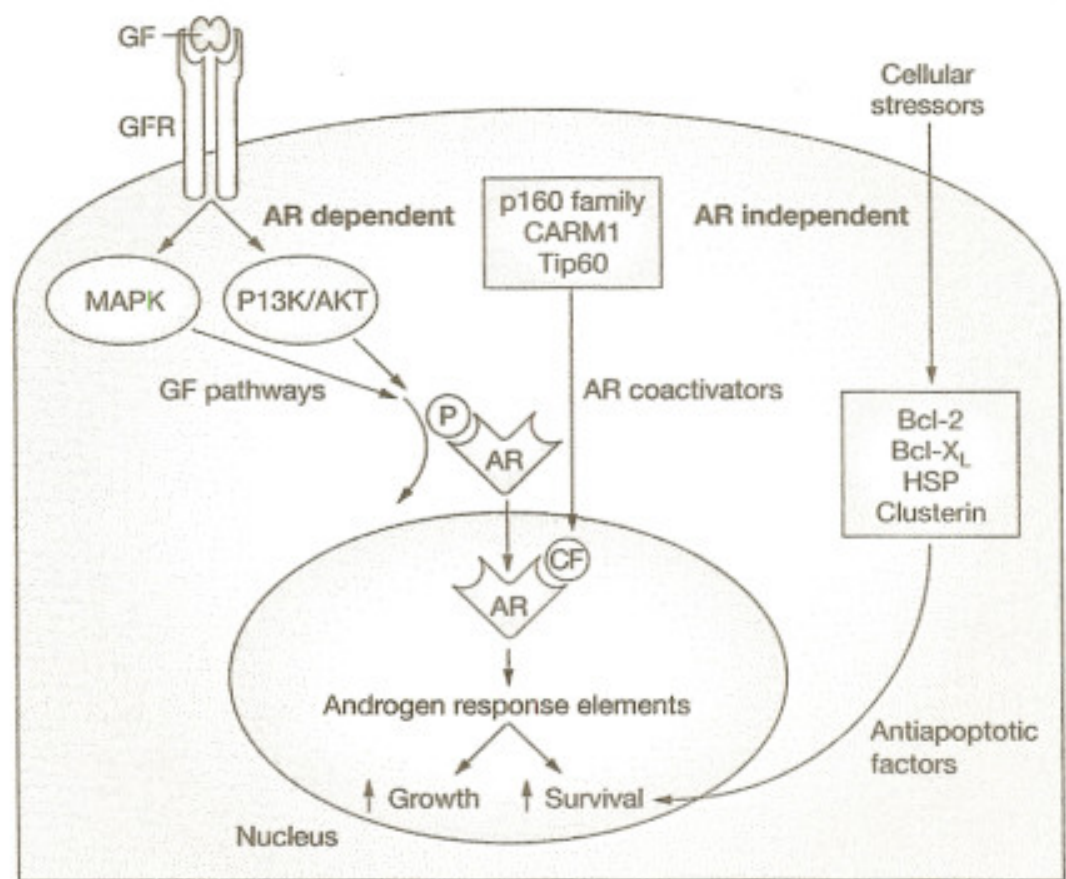

Figure 1 Three possible pathways leading to androgen-independent prostate cancer. Growth factor signaling cascades may activate the AR by phosphorylation in the absence of ligand. Coactivators modify transcriptional activity of the AR. When activated, the AR enters the nucleus, binds to androgen response elements, and transcribes specific genes promoting survival and proliferation. Antiapoptotic factors increase in response to cellular stressors, also promoting survival. Abbreviations: AR, androgen receptor; CARM1, coactivator-associated arginine methyltransferase 1; CF, cofactor; GF, growth factor; GFR, growth factor receptor; HSP, heat-shock protein; $\mathrm{P}$, phosphate group; MAPK, mitogen-activated protein kinase; PI3K, phosphoinositide 3-kinase; Tip60, Tat interacting protein $60 \mathrm{kDa}$.

EGF receptor (EGFR), activating the intracellular tyrosine kinase domain with subsequent effects mediated by multiple pathways. Two of the most important involve mitogen-activated protein kinase (MAPK) and phosphoinositide 3-kinase (PI3K). Both of these pathways can activate the AR by phosphorylation independently of a natural ligand, in addition to other effects that promote cell proliferation and oppose apoptosis in an androgen-independent manner. Consistent with this mechanism, activation of MAPK was shown to be increased following ADT. ${ }^{8}$

Expression of the EGFR and its subtype HER $2 /$ neu in prostate cancer is the subject of controversy. Lorenzo et al. ${ }^{9}$ reviewed 14 studies, which variously showed expression of HER 2 /neu to be present in $0-100 \%$ of prostate tumors. There is, however, greater uniformity in evidence supporting HER2/neu upregulation by ADT. 
Table 1 Castration-induced changes in androgen receptor cofactors possibly involved in androgen receptor-dependent prostate cancer progression.

\begin{tabular}{|c|c|c|c|c|}
\hline Factor & $\begin{array}{l}\text { CaP related } \\
\text { physiology }\end{array}$ & $\begin{array}{l}\text { Castration } \\
\text { related changes }\end{array}$ & $\begin{array}{l}\text { Potential } \\
\text { clinical role }\end{array}$ & $\begin{array}{l}\text { Selected } \\
\text { references }\end{array}$ \\
\hline ARA70 & AR coactivator & $\begin{array}{l}\text { Initial decrease; } \\
\text { increased with Al } \\
\text { progression }\end{array}$ & $\begin{array}{l}\text { Future: blockade } \\
\text { may decrease Al } \\
\text { AR signaling }\end{array}$ & 54 \\
\hline CARM $1^{a}$ & AR coactivator ${ }^{a}$ & Increased ${ }^{a}$ & Future target ${ }^{\mathrm{a}}$ & 55 \\
\hline $\begin{array}{l}\text { p160 } \\
\text { familya }\end{array}$ & $\begin{array}{l}\text { Family of AR } \\
\text { coactivators } \\
\text { including Src-1, } \\
\text { TIF- } 2 \text { and } \mathrm{RAC}-3^{\mathrm{a}}\end{array}$ & Increased ${ }^{a}$ & $\begin{array}{l}\text { Future: blockade } \\
\text { may decrease Al } \\
\text { AR signaling }^{a}\end{array}$ & 7 \\
\hline $\begin{array}{l}\text { p300 } \\
\text { (CBP) }\end{array}$ & AR coactivator & Unknown & $\begin{array}{l}\text { Future: blockade } \\
\text { may decrease Al } \\
\text { AR signaling }\end{array}$ & 56 \\
\hline Tip60a & AR coactivator ${ }^{2}$ & Increased ${ }^{\text {a }}$ & $\begin{array}{l}\text { Future: blockade } \\
\text { may decrease AI } \\
\text { AR signaling }\end{array}$ & 57 \\
\hline
\end{tabular}

aStudies in human subjects available for review. Abbreviations: $\mathrm{Al}$, androgen independent; AR, androgen receptor; ARA70, androgen receptor associated protein $70 ; \mathrm{CaP}$, prostate cancer; CARM1, coactivator-associated arginine methyltransferase 1; CBP, CREB binding protein; RAC-3, nuclear receptor coactivator $3 ;$ Tip 60 , Tat interacting protein $60 \mathrm{kDa} ; \mathrm{TIF}-2$, transcription intermediary factor 2 .

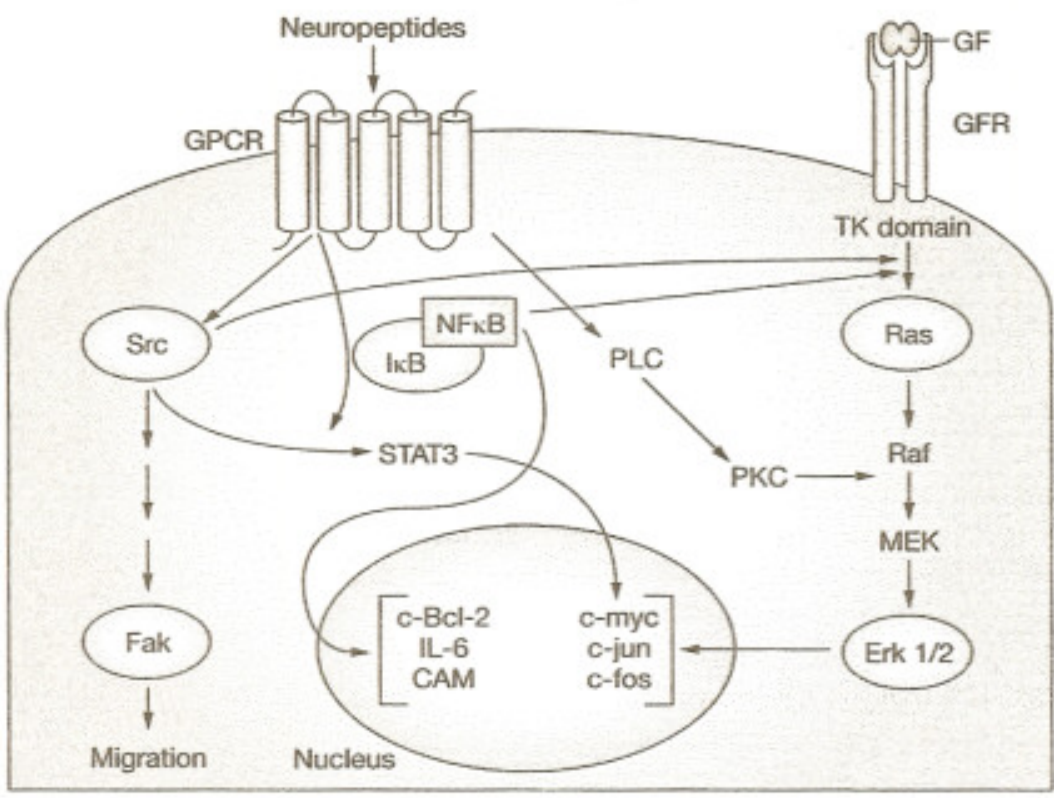

Figure 2 Comparison of growth factor and neuropeptide signaling pathways emphasizing cross-talk between them. Growth factors activate receptors with intracellular TK domains, subsequently activating a signaling cascade through Ras leading to modification of transcription. Neuropeptides activate GPCR, activating Src and NFKB by separation from its binding protein IкB. Both of these may activate growth factor receptor TK domains as well as affecting transcription of various factors. The GPCR may also activate other signaling cascades through Src and PLC/PKC. Abbreviations: CAM, cell adhesion molecule; GF, growth factor; GFR, growth factor receptor; GPCR, G-protein coupled receptor; IkB, inhibitor of $\kappa B$; IL-6, interleukin 6; NFKB, nuclear factor $\kappa B$; PKC, protein kinase C; PLC, phospholipase C; TK, tyrosine kinase.
Three of four studies reported that there were significant increases in this receptor following administration of ADT, and the study that did not demonstrate this effect reported a significant increase in EGFR overall compared to pre-ADT levels. Phase II trials of the monoclonal antibody (mAb) against HER2/neu, trastuzumab, have, however, been limited due to low levels of expression of the receptor in the screened patients. Screening produced generally disappointing results in the few patients tested. ${ }^{10,11}$ Other trials of mAbs against the extracellular or intracellular domains of the EGFR are ongoing. ${ }^{12,13}$ Other therapeutic options that target the EGFR include small-molecule inhibitors of the intracellular tyrosine kinase domain, such as gefitinib and erlotinib. Unfortunately, trials using these drugs as monotherapies have not demonstrated a clear benefit to patients. ${ }^{14}$

The insulin-like growth factor (IGF) pathway functions in a similar way to the pathways outlined earlier. In contrast to EGF, no consistent changes in IGF or its receptors are noted in men who have undergone castration, ${ }^{5}$ but two patients with advanced disease did show increased IGF-1 receptor levels. ${ }^{15}$ Of more interest is the finding that the levels of several IGF binding proteins (IGFBP) change in response to ADT; IGFBP2 and IGFBP5 both increase acutely and IGFBP3 decreases within weeks of initiation of ADT. ${ }^{16-18}$ All of these changes might increase the effect of IGF signaling through the PI3K pathway.

Many other growth factors, neuropeptides and cytokines have been shown to activate signaling pathways in a similar manner to IGF and EGF, resulting in activation of the AR (Tables 2-5). The downregulation of neutral endopeptidase at castration is thought to provide an important source for increasing levels of growth factors and neuropeptides, as the enzyme is the primary means of degrading these cellular signals. ${ }^{19}$ Almost all of the specific growth factors and receptors have antagonists that are undergoing early clinical trials. These were recently reviewed by van der Poel. ${ }^{12}$

The multiplicity of growth factors and neuropeptides leads to significant cross-talk between the cell signaling pathways (Figure 2). The many pathways lead to the same effectors, which might make downstream targets, that impact on multiple pathways, more likely to exhibit significant inhibitory effects. One such target is the Src family kinases, which are 
Table 2 Castration-induced changes in growth factors possibly involved in androgen receptor-dependent prostate cancer progression.

\begin{tabular}{|c|c|c|c|c|}
\hline Factor & CaP related physiology & $\begin{array}{l}\text { Castration related } \\
\text { changes }\end{array}$ & Potential clinical role & $\begin{array}{l}\text { Selected } \\
\text { references }\end{array}$ \\
\hline EGF family & $\begin{array}{l}\text { Ligand for receptor tyrosine } \\
\text { kinases initiating multiple } \\
\text { signaling cascades }\end{array}$ & Some are increased & $\begin{array}{l}\text { See EGF receptor } \\
\text { blockers }\end{array}$ & 58 \\
\hline FGF family ${ }^{a}$ & $\begin{array}{l}\text { Binds receptor with generally } \\
\text { trophic effects }\end{array}$ & FGF-8 increased $^{\mathrm{a}}$ & $\begin{array}{l}\text { TNP- } 470 \text { inhibits } \\
\text { binding, no effect in } \\
\text { early trials }\end{array}$ & 58,59 \\
\hline HGFa & Coactivator of $\mathrm{AR}^{\mathrm{a}}$ & Increased ${ }^{\mathrm{a}}$ & $\begin{array}{l}\text { Future inhibitor may } \\
\text { decrease AR effects in } \\
\text { Al CaPa }\end{array}$ & 60 \\
\hline IGF-1a & $\begin{array}{l}\text { Ligand for receptor tyrosine } \\
\text { kinases initiating multiple } \\
\text { signaling cascades }\end{array}$ & No change ${ }^{a}$ & $\begin{array}{l}\text { Future inhibitor may } \\
\text { decrease AR effects in } \\
\text { Al CaPa }\end{array}$ & 5,58 \\
\hline $\begin{array}{l}\text { IGFBP-2, } \\
\text { IGFBP-5 }\end{array}$ & $\begin{array}{l}\text { Increases IGF signal } \\
\text { transduction }{ }^{\mathrm{a}}\end{array}$ & Increased $^{a}$ & ASOs show activity ${ }^{a}$ & $16,17,61$ \\
\hline IGFBP-3 $^{\mathrm{a}}$ & $\begin{array}{l}\text { Decreases IGF signal } \\
\text { transduction }^{\mathrm{a}}\end{array}$ & Decreased $^{\mathrm{a}}$ & Prognostic indicator ${ }^{a}$ & 18 \\
\hline TGF- $\beta 1^{a}$ & $\begin{array}{l}\text { Ligand for receptor tyrosine } \\
\text { kinases initiating multiple } \\
\text { signaling cascades }\end{array}$ & Increased in some ${ }^{a}$ & Prognostic factor ${ }^{\mathrm{a}}$ & 35 \\
\hline VEGFa & $\begin{array}{l}\text { Angiogenesis and cell } \\
\text { motility }\end{array}$ & $\begin{array}{l}\text { Initial decrease; NE cells } \\
\text { continue to produce }^{\mathrm{a}}\end{array}$ & $\begin{array}{l}\text { mAb to VEGF } \\
\text { (bevacizumab) } \\
\text { specifically inhibits } \\
\text { tyrosine kinase } \\
\text { activity }\end{array}$ & $\begin{array}{l}12,36,62, \\
63\end{array}$ \\
\hline
\end{tabular}

astudies in human subjects avaliable for review. Abbreviations: AJ, androgen independent; AR, androgen receptor; ASO, antisense oligonucleotide; CaP, prostate cancer; EGF, epidermal growth factor; FGF, fibroblast growth factor, HGF, hepatocyte growth factor: IGF, insulin-like growth factor, IGFBP, IGF binding protein; mAb, monoclonal antibody; NE, neuroendocrine; TGF, transforming growth factor, VEGF, vascular endothelial growth factor.

Table 3 Castration-induced changes in receptors possibly involved in androgen receptor-dependent prostate cancer progression.

\begin{tabular}{|c|c|c|c|c|}
\hline Factor & CaP related physiology & $\begin{array}{l}\text { Castration related } \\
\text { changes }\end{array}$ & Potential clinical role & $\begin{array}{l}\text { Selected } \\
\text { references }\end{array}$ \\
\hline EGFR $^{a}$ & $\begin{array}{l}\text { Receptor with intracellular } \\
\text { tyrosine kinase domain } \\
\text { activating multiple } \\
\text { pathways }\end{array}$ & Increased $^{\mathrm{a}}$ & $\begin{array}{l}\text { Multiple mAb and } \\
\text { tyrosine kinase } \\
\text { inhibitors }\end{array}$ & $9,12,64$ \\
\hline $\begin{array}{l}\text { ErbB2/ } \\
\text { HER-2/neu }\end{array}$ & $\begin{array}{l}\text { Receptor with intracellular } \\
\text { tyrosine kinase domain } \\
\text { activating multiple pathways }\end{array}$ & $\begin{array}{l}\text { ADT selects } \\
\text { for HER-2/neu } \\
\text { expressing cells }\end{array}$ & $\begin{array}{l}\text { Multiple mAb and } \\
\text { tyrosine kinase inhibitors }\end{array}$ & 9,12 \\
\hline FGFR-2 ${ }^{\mathrm{a}}$ & $\begin{array}{l}\text { Binds ligand with effects on } \\
\text { angiogenesis and wound } \\
\text { healing }^{\mathrm{a}}\end{array}$ & Decreased ${ }^{a}$ & NR & 65 \\
\hline IGF-1R & $\begin{array}{l}\text { Binds ligand initiating } \\
\text { multiple signaling } \\
\text { cascades }^{\mathrm{a}}\end{array}$ & $\begin{array}{l}\text { Increased } \\
\text { in } 2 \text { patients }\end{array}$ & $\begin{array}{l}\text { Small molecule inhibitors } \\
\text { show some activity in } \\
\text { other cancers }\end{array}$ & 15 \\
\hline $\begin{array}{l}\text { TGF- } \beta 1 R 1^{\mathrm{a}} \\
\text { and TGF- } \beta 1 R 2^{\mathrm{a}}\end{array}$ & $\begin{array}{l}\text { Binds ligand with complex } \\
\text { cell signaling effects }\end{array}$ & $\begin{array}{l}\text { Increased in some } \\
\text { cancers }^{a}\end{array}$ & Prognostic factor ${ }^{a}$ & 35 \\
\hline $\begin{array}{l}\text { Serotonin } \\
\text { receptor } 2 \mathrm{~B},{ }^{\mathrm{a}} \\
\text { serotonin } \\
\text { receptor } 4^{\mathrm{a}}\end{array}$ & $\begin{array}{l}\text { Active in autocrine and } \\
\text { paracrine signaling } \\
\text { supporting Al growth }\end{array}$ & $\begin{array}{l}\text { Receptor } 4 \\
\text { increased }^{\mathrm{a}}\end{array}$ & $\begin{array}{l}\text { Serotonin receptor } \\
\text { antagonists inhibit CaP } \\
\text { cell growth; Al cells more } \\
\text { sensitive }^{\mathrm{a}}\end{array}$ & 66 \\
\hline
\end{tabular}

aStudies in human subjects available for review. Abbreviations: ADT, androgen deprivation therapy; CaP, prostate cancer; EGFR, epidermal growth factor receptor; FGFR, fibroblast growth factor receptor, IGF-1A, insulin-ikke growrth factor receptor 1 ; mAb, monoclonal antibody; NR, not reported; TGF $11 R$, transforming growth factor receptor- $\beta 1$. 
Table 4 Castration-induced changes in neuropeptides possibly involved in androgen receptor-independent prostate cancer progression.

\begin{tabular}{|c|c|c|c|c|}
\hline Factor & CaP related physiology & $\begin{array}{l}\text { Castration related } \\
\text { changes }\end{array}$ & Potential clinical role & $\begin{array}{l}\text { Selected } \\
\text { references }\end{array}$ \\
\hline Calcitonin & $\begin{array}{l}\text { Angiogenesis, invasiveness } \\
\text { stimulation through PKA, AKT } \\
\text { and others }\end{array}$ & $\begin{array}{l}\text { Produced by NE cells } \\
\text { unaffected by ADT }\end{array}$ & $\begin{array}{l}\text { Blockade may allow } \\
\text { apoptosis in response } \\
\text { to chemotherapy }\end{array}$ & 68,76 \\
\hline Endothelin-1 & $\begin{array}{l}\text { Angiogenesis, osteoblastic } \\
\text { lesion formation, } \\
\text { neuropeptide for multiple } \\
\text { receptors }\end{array}$ & $\begin{array}{l}\text { Increased in } \mathrm{CaP} \text { in } \\
\text { general; endothelin } \\
\text { receptors increased } \\
\text { by ADT }\end{array}$ & $\begin{array}{l}\text { Endothelin-A receptor } \\
\text { antagonist, atrasentan, } \\
\text { in phase } 1 \mathrm{l} / \mathrm{lll} \text { studies }\end{array}$ & $\begin{array}{l}12,21,38 \\
69\end{array}$ \\
\hline ProGRPa & Proneuropeptide ${ }^{a}$ & Follows level of NED ${ }^{a}$ & Marker for $\mathrm{NED}^{\mathrm{a}}$ & 70 \\
\hline $\begin{array}{l}\text { GRP/ } \\
\text { bombesin }\end{array}$ & $\begin{array}{l}\text { Stimulates Al growth; multiple } \\
\text { effects through NFKB }\end{array}$ & Follows level of NED & $\begin{array}{l}\text { Marker for NED; } \\
\text { prognostic utility }\end{array}$ & $\begin{array}{l}20,67,68 \\
70,71\end{array}$ \\
\hline $\operatorname{NEP}(C D 10)^{a}$ & $\begin{array}{l}\text { Cleaves many neuropeptides } \\
\text { controlling extracellular } \\
\text { concentrations }^{\text {a }}\end{array}$ & Decreased $^{a}$ & $\begin{array}{l}\text { Increasing NEP } \\
\text { expression through } \\
\text { gene constructs } \\
\text { possible future } \\
\text { treatment }^{a}\end{array}$ & 19 \\
\hline Neurotensin & $\begin{array}{l}\text { Neuropeptide stimulates } \\
\text { androgen independent growth }\end{array}$ & Increased in NE cells & Marker for NED & $20,21,72$ \\
\hline PTHrP & $\begin{array}{l}\text { Multiple bioactive proteins } \\
\text { from initial transcript; generally } \\
\text { trophic neuropeptide }\end{array}$ & Increased & $\begin{array}{l}\text { Anti-PTHrP mAb } \\
\text { inhibits hypercalcemia } \\
\text { of malignancy }\end{array}$ & 67,72 \\
\hline Serotonin ${ }^{a}$ & $\begin{array}{l}\text { Binds multiple receptors } \\
\text { supporting Al growth }\end{array}$ & Increased ${ }^{\mathrm{a}}$ & Serotonin antagonists ${ }^{a}$ & $66,67,73$ \\
\hline Somatostatin ${ }^{\mathrm{a}}$ & $\begin{array}{l}\text { Inhibits angiogenesis, } \\
\text { proliferation, stimulates } \\
\text { apoptosis" }\end{array}$ & $\begin{array}{l}\text { Receptors are } \\
\text { upregulated in } \mathrm{CaP} \text { in } \\
\text { general; produced by } \\
\text { NE cells }\end{array}$ & Somatostatin analogs ${ }^{a}$ & 73 \\
\hline VIP & $\begin{array}{l}\text { Activates ERK } 1 / 2 \text {, PI3K and } \\
\text { other pathways supporting Al } \\
\text { growth }\end{array}$ & Unknown & NR & 74 \\
\hline
\end{tabular}

aStudies in human subjects available for review. Abbreviations: ADT, androgen deprivation therapy; Al, androgen independent; GaP, prostate cancer, ERK, extracellular-signal-regulated protein kinase; GRP, gastrin releasing peptide; mAb, monoclonal antibody; NE, neuroendocrine: NED, neuroendocrine differentiation; NEP. neutral endopeptidase; NFKB, nuclear factor KB; NR, not reported; PI3K, phosphoinositide 3-kinase; PKA. protein kinase A: PTHrP, parathyroid hormone related protein; VIP, vasoactive intestinal peptide.

nonreceptor tyrosine kinases that participate in a variety of intracellular pathways stimulated by neuropeptides. ${ }^{20}$ In addition, Src kinases can activate STAT3, a transcription factor that subsequently activates cyclin D1, vascular endothelial growth factor (VEGF), and $\mathrm{c}-\mathrm{myc}$. $^{21}$ The activities represented by these pathways are clearly involved in the progression of androgen-independent prostate cancer. Two selective non-receptor tyrosine kinase inhibitors, MBS-354825 (dasatinib) and AZD0530, are both undergoing phase II investigation sponsored by the National Cancer Institute for use in patients with androgen-independent prostate cancer. ${ }^{22,23}$ Inhibitory molecules, such as the nonreceptor tyrosine kinases, have shown therapeutic promise in vitro ${ }^{24}$ and might prove to be good treatment options for men with androgen-independent prostate cancer.

\section{ANDROGEN-RECEPTOR-INDEPENDENT PATHWAYS}

\section{Antiapoptotic pathways}

Multiple pathways lead to apoptosis and several cellular proteins involved in apoptosis show changes following castration (Table 6). The Bcl family of proteins includes both proapoptotic and antiapoptotic members, the balance of which is critical for maintaining cellular homeostasis. The antiapoptotic Bcl-2 is consistently upregulated by castration and probably has an important role in allowing androgenindependent progression of prostate cancer. ${ }^{25-27}$ The antisense oligonucleotide (ASO) against 
Table 5 Castration-induced changes in interleukins possibly involved in androgen receptor-independent prostate cancer progression.

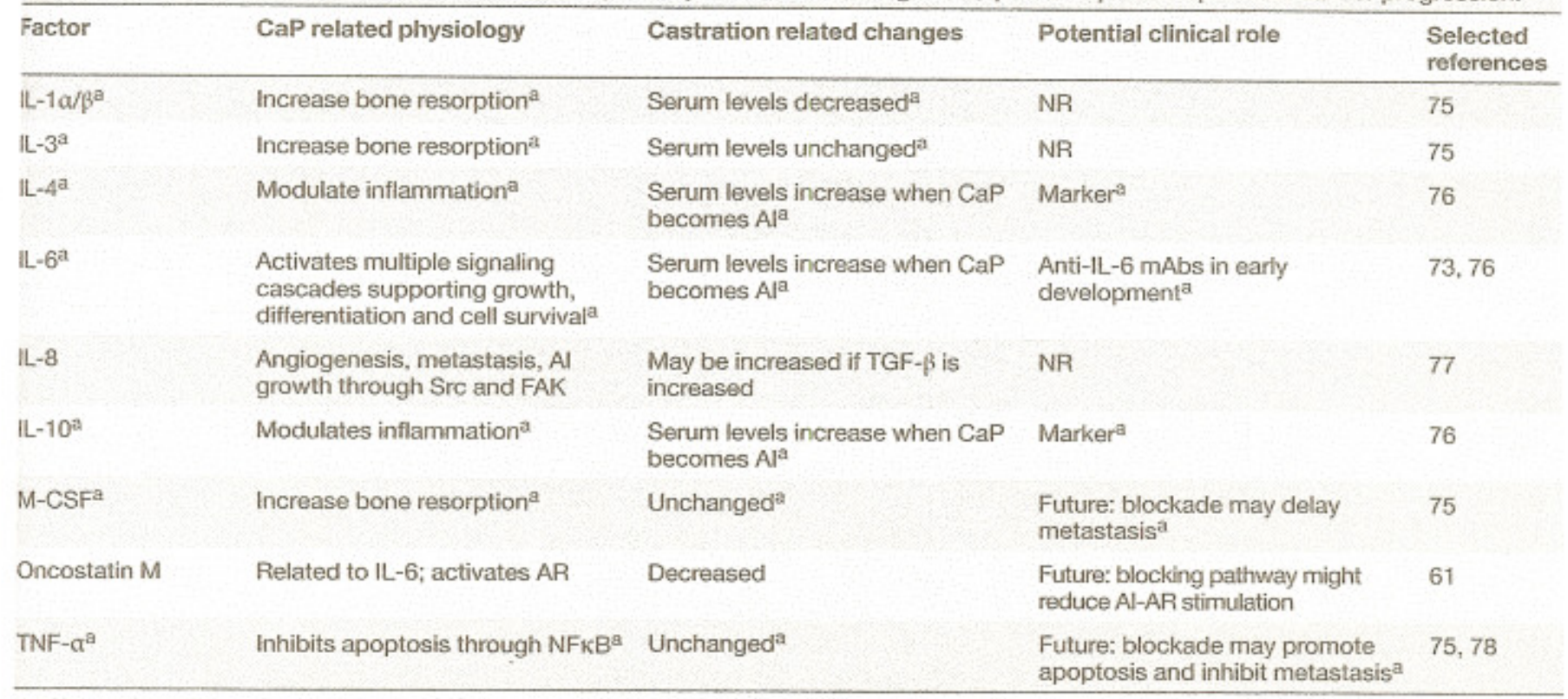

aStudies in human subjects available for review. Abbreviations: Al, androgen independent; AR, androgen receptor; CaP, prostate cancer; FAK, focal adhesion kinase; IL, interleukin; M-CSF, macrophage colony stimulating factor; mAb, monoclonal antibody; NFKB, nuclear factor kB; NR, not reported; TGF, transforming growth factor; TNF, tumor necrosis factor.

Table 6 Castration-induced changes in apoptosis regulators possibly involved in androgen receptor-independent prostate cancer progression.

\begin{tabular}{|c|c|c|c|c|}
\hline Factor & CaP related physiology & Castration related changes & Potential clinical role & $\begin{array}{l}\text { Selected } \\
\text { references }\end{array}$ \\
\hline $\mathrm{Bcl}-2^{\mathrm{a}}$ & $\begin{array}{l}\text { Family of factors both } \\
\text { proapoptotic and antiapoptotic; } \\
\text { balance determines cell survival }^{\mathrm{a}}\end{array}$ & Increased ${ }^{a}$ & $\begin{array}{l}\text { ASO oblimersen sodium is } \\
\text { undergoing trials }\end{array}$ & $25-27,64$ \\
\hline Clusterin $^{a}$ & $\begin{array}{l}\text { Nuclear chaperone inhibits } \\
\text { apoptosis }^{a}\end{array}$ & Increased $\mathrm{a}^{\mathrm{a}}$ & $\begin{array}{l}\text { ASOs show promise in early } \\
\text { trials }^{\mathrm{a}}\end{array}$ & 31,32 \\
\hline $\begin{array}{l}\text { HSP27, HSP60, } \\
\text { HSP70, HSPg0a }\end{array}$ & $\begin{array}{l}\text { Nuclear chaparones bind } \\
\text { denatured proteins; prevent } \\
\text { apoptosis }\end{array}$ & Most increased ${ }^{a}$ & $\begin{array}{l}\text { ASO and siRNA to HSP27 in } \\
\text { early trials; geldanamycin and } \\
\text { other ansamycins inhibit HSP90 }\end{array}$ & 30,61 \\
\hline IAPs & Apoptotic inhibitor & $\begin{array}{l}\text { Survivin and others increased in } \\
\text { NE cells }\end{array}$ & $\begin{array}{l}\text { ASOs have shown promise; must } \\
\text { target multiple IAPs }\end{array}$ & 79 \\
\hline $\mathrm{p} 53^{\mathrm{a}}$ & $\begin{array}{l}\text { Cell cycle regulator; } \\
\text { proapoptotic }^{\mathrm{a}}\end{array}$ & Increased $^{9}$ & NR & $34,64,80$ \\
\hline p21 (WAF1, CIP1) & $\begin{array}{l}\text { Effector for p53; halts cell cycle } \\
\text { in G1 }\end{array}$ & Increased ${ }^{a}$ & Prognostic indicator ${ }^{a}$ & 34 \\
\hline
\end{tabular}

sStudies in human subjects available for review. Abbreviations: ASO, antisense oligonucleotide; CaP, prostate cancer; HSP, heat shock protein; LAP, inhibitorof-apoptosis protein: NE, neuroendocrine; NR, not reported; siRNA, small interfering RNA

Bcl-2 has shown activity, both in vitro and in vivo, delaying the progression to androgenindependent disease. ${ }^{28}$ Recent phase II results in androgen-independent prostate cancer showed tolerability in combination with docetaxel and an impressive $80 \%$ response rate in the subset of patients achieving high serum concentrations of the oligonucleotide. ${ }^{29}$
Another cellular pathway leading to apoptosis is induced by the accumulation of denatured proteins in the cell. Cellular stress leads to this condition and increasing numbers of dysfunctional proteins may precipitate, signaling caspase activation. The term 'heat shock protein' (HSP) encompasses a large family of related proteins that function as 'chaperones' to stabilize the 
Table 7 Castration-induced changes in cell wall factors possibly involved in androgen receptor-independent prostate cancer progression.

\begin{tabular}{|c|c|c|c|c|}
\hline Factor & CaP related physiology & Castration related changes & Potential clinical role & $\begin{array}{l}\text { Selected } \\
\text { references }\end{array}$ \\
\hline Caveolin & $\begin{array}{l}\text { Component of plasma membrane pits } \\
\text { involved in cell signaling }\end{array}$ & Decreased & NR & 81 \\
\hline FAK & $\begin{array}{l}\text { Cell motility/metastasis; } \\
\text { signaling pathways }\end{array}$ & $\begin{array}{l}\text { Possibly increased if NE GF } \\
\text { pathways increased }\end{array}$ & $\begin{array}{l}\text { Genistein alters FAK activity, } \\
\text { may reduce metastasis }\end{array}$ & 46,77 \\
\hline Fibronectin & $\begin{array}{l}\text { Cell adhesion through interaction with } \\
\text { integrin }\end{array}$ & Increased $60 x$ in vitro & $\begin{array}{l}\text { Future: blocking upregulation } \\
\text { to decrease metastatic potential }\end{array}$ & 43 \\
\hline ILK & $\begin{array}{l}\text { Protein kinase linking cell adhesion to } \\
\text { signaling; negatively regulated by PTEN }\end{array}$ & None & $\begin{array}{l}\text { Future: inhibit in tumors with } \\
\text { PTEN mutation }\end{array}$ & 82 \\
\hline $\begin{array}{l}\text { MMP-2, } \\
\text { MMP-9 }\end{array}$ & $\begin{array}{l}\text { Cleaves basement membrane } \\
\text { constituents; possible role in invasion/ } \\
\text { metastasis }\end{array}$ & Inconsistent & $\begin{array}{l}\text { Many MMP inhibitors may have } \\
\text { clinical utility in combination; } \\
\text { prognostic utility }\end{array}$ & 83 \\
\hline Mucin & $\begin{array}{l}\text { Family of glycoproteins modulating } \\
\text { cell adhesion }\end{array}$ & Most are increased & $\begin{array}{l}\text { Vaccines targeting MUC-1 } \\
\text { peptidea }^{\mathrm{a}}\end{array}$ & 44,45 \\
\hline $\begin{array}{l}\text { Syndecan-1 } \\
(\mathrm{CD}-138)^{\mathrm{a}}\end{array}$ & $\begin{array}{l}\text { Binds matrix proteins and growth } \\
\text { factors; involved with adhesion and } \\
\text { differentiation }\end{array}$ & Increased $^{a}$ & Possible role in immunotherapy ${ }^{a}$ & 64,84 \\
\hline $\begin{array}{l}\text { TIMP-1, } \\
\text { TIMP-2 }\end{array}$ & Inhibits MMPs & Inconsistent; opposite MMP & $\begin{array}{l}\text { Analogs could decrease MMP } \\
\text { expression; regulation of } \\
\text { endogenous levels possible }\end{array}$ & 85,86 \\
\hline
\end{tabular}

astudies in human subjects available for review. Abbreviations: CaP, prostate cancer: FAK, focal adhesion kinase; GF, growth factor; ILK, integrin-linked kinase; MMP, matrix metalloproteinase; MUC-1, urinary mucin 1: NE, neuroendocrine; NR, not reported; PTEN, phosphatase and tensin homolog; TIMP, tissue inhibitor of matrix metalloproteinase.

denatured proteins that result from cellular stress. The cell thereby becomes more resistant to apoptosis induced by multiple factors such as heat, radiation, and toxic drugs. As would be expected, many of the HSPs change expression in response to the stress of castration (Table 6). HSP27 has been extensively studied and might represent another important pathway of resistance to apoptosis in the androgen-independent state. In addition to its functions as a chaperone, HSP27 also directly interferes with caspase activation, modulates cellular oxidative stress, and stabilizes the cytoskeleton. The upregulation of HSP27 can be targeted by ASOs or small interfering RNA, and both of these therapies are entering phase I/II trials. ${ }^{30}$

Clusterin is a nuclear protein that also functions as a chaperone. One isoform of clusterin shows greater potency than even heat shock proteins to 'stabilize' denatured proteins. Levels of clusterin increase significantly following castration and might be an important signal inhibiting apoptosis. ${ }^{31,32}$ An ASO against the clusterin gene successfully decreases expression, causing an increase in apoptosis in cells exposed to multiple chemotherapeutic drugs, radiation, and oxidative stress. A phase I trial showed the clusterin ASO OGX-011 to have acceptable toxicity at effective plasma concentrations. ${ }^{33}$ Phase II trials are underway to further define the role of ASOs in prostate cancer therapy. ${ }^{30}$

The antiapoptotic changes discussed above can be counteracted by the p 53 protein, which inhibits the cell cycle when DNA damage has occurred. After the dividing cell is held in the G1 stage, apoptosis is induced by a mechanism (not yet fully understood) involving both the p53 protein and its effector $\mathrm{p} 21$. Both these proteins are upregulated by castration. It has, however, been suggested that one or both might be mutated and nonfunctional. ${ }^{34}$ This would upset the balance of proapoptotic and antiapoptotic signals within the cell, allowing resistance to ADT to develop and thereby facilitating the emergence of androgen-independent prostate cancer.

\section{Miscellaneous pathways}

The intricate pathways of cellular homeostasis show wide-ranging effects following castration. The brief discussion of the following three pathways highlights their potential importance to castration-adjunctive therapy. 
Table 8 Castration-induced changes in signal transduction factors possibly involved in androgen receptor-independent prostate cancer progression.

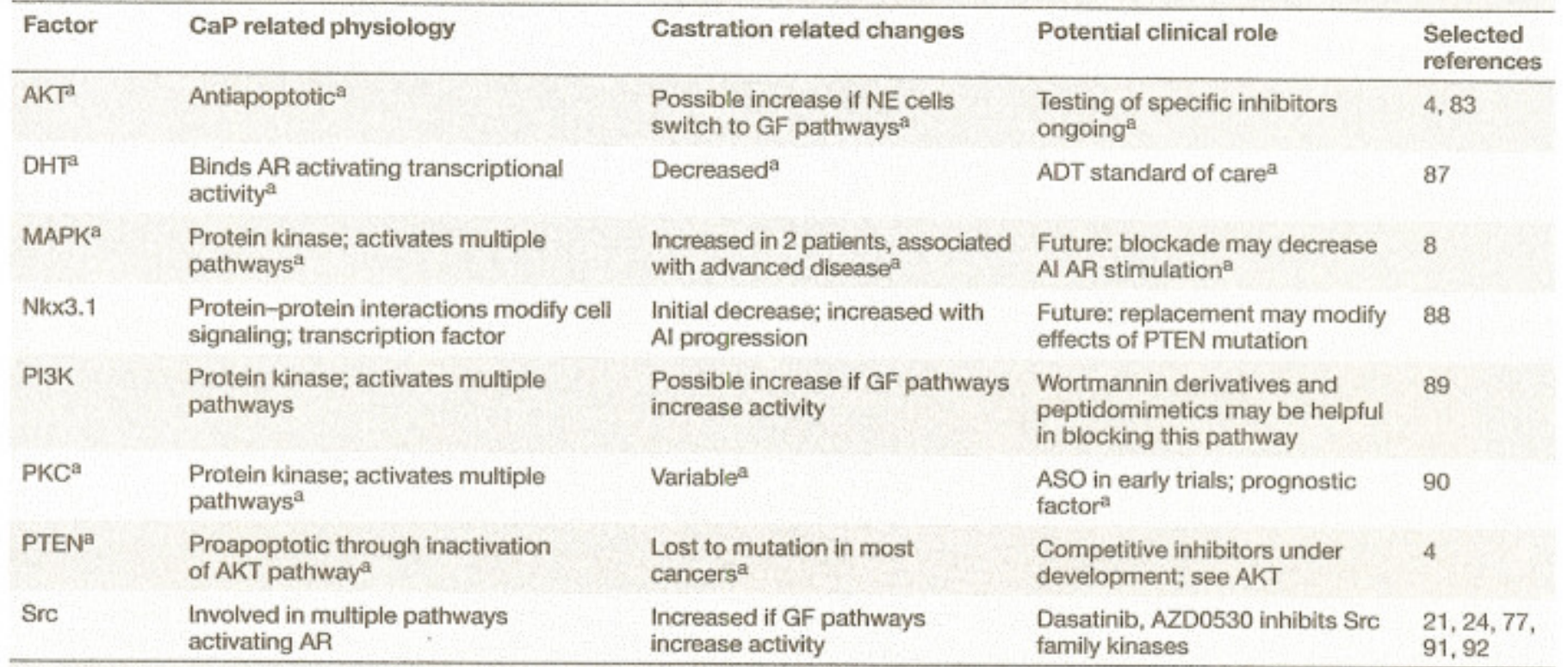

aStudies in human subjects available for review. Abbreviations: ADT, androgen deprivation therapy; Al, androgen independent; AR, androgen receptor; ASO, antisense oligonucleotide; GaP, prostate cancer; DHT, dilydrotestosterone; GF, growth factor; MAPK, mitogen-activated protein kinase; NE, neuroendocrine; PI3K, phosphoinositide 3-kinase; PKC, protein kinase C; PTEN, phosphatase and tensin homolog.

Angiogenesis is necessary for tumor growth, and some of the factors known to be upregulated in androgen-independent prostate cancer stimulate angiogenesis (Table 2). For example, TGF $\beta$ is upregulated following castration, ${ }^{35}$ and VEGF is produced by androgenindependent neuroendocrine cells, which are relatively unaffected by ADT. ${ }^{36}$ Furthermore, VEGF levels are an independent prognostic factor in androgen-independent prostate cancer. ${ }^{37}$ Broad spectrum antiangiogenic drugs such as suramin analogs and thalidomide have shown activity, singly and in combination, in early trials. ${ }^{38}$ Targeted treatment with the $\mathrm{mAb}$ against VEGF, bevacizumab, showed some activity in combination with chemotherapy. 39 Ongoing trial results are awaited.

Multiple factors regulating cellular adhesion change expression level in response to ADT (Tables 7 and 8), and those that do not change may still be attractive targets for treatment to inhibit invasion or metastasis. Antimetastatic therapies might have the added advantage of modifying cellular signaling in addition to their intended cellular adhesion effects. For example, fibronectin interacts with integrins to affect cellular adhesion. These interactions also activate intracellular domains through focal adhesion kinase, however (Table 7), and subsequently by MAPK or PI3K activation (Table 8) leading to multiple effects as outlined above. ${ }^{40,41}$ Stewart et al. ${ }^{42}$ provide an excellent review of changes in the extracellular matrix associated with prostate cancer progression. The data specifically related to castration is more limited. In vitro, fibronectin expression is increased over 60 -fold in androgen-independent clones ${ }^{43}$ and mucin expression also undergoes significant changes. ${ }^{44}$ Current treatment strategies based on these observations are under development. The expression of mucin type 1 by neoplastic cells has inspired attempts at vaccine creation. ${ }^{45}$ In addition, part of the putative activity of genistein in opposing neoplastic progression might be caused by alteration of signaling involving focal adhesion kinase. ${ }^{46}$

A factor that encompasses multiple effects is nuclear factor $\kappa \mathrm{B}(\mathrm{NF} \kappa \mathrm{B})$, a nuclear transcription factor (Table 9). Multiple pathways can phosphorylate inhibitor of $\kappa \mathrm{B}$ (IкB), the cytosolic binding protein for $\mathrm{NF} \kappa \mathrm{B}$, causing the release of NFKB, which quickly translocates to the nucleus. Once in the nucleus, NFKB facilitates transcription of multiple genes associated with inflammation (e.g interleukins 1 and 6 and tumor necrosis factor- $\alpha$ [Table 5]), cell adhesion 
Table 9 Castration-induced changes in transcription factors possibly involved in androgen receptor-independent prostate cancer progression.

\begin{tabular}{|c|c|c|c|c|}
\hline Factor & CaP related physiology & $\begin{array}{l}\text { Castration related } \\
\text { changes }\end{array}$ & Potential clinical role & $\begin{array}{l}\text { Selected } \\
\text { references }\end{array}$ \\
\hline $\mathrm{AR}^{\mathrm{a}}$ & $\begin{array}{l}\text { Androgen binding induces dimerization, activating } \\
\text { transcription factor activity for many genes }\end{array}$ & Increaseda & $\begin{array}{l}\text { Future: blocking downstream signals } \\
\text { completely }\end{array}$ & 3,73 \\
\hline c-Fos ${ }^{a}$ & $\begin{array}{l}\text { Combines with c-Jun to make AP-1 transcription } \\
\text { factor }^{\mathrm{a}}\end{array}$ & Variable $^{\mathrm{a}}$ & Prognostic factora & 90 \\
\hline C-Jun ${ }^{a}$ & $\begin{array}{l}\text { Dimerizes or combines with c-Fos to make AP-1 } \\
\text { transcription factor }^{\mathrm{a}}\end{array}$ & Variable ${ }^{a}$ & Prognostic factor ${ }^{a}$ & 90 \\
\hline c-Myc & $\begin{array}{l}\text { Transcription factor; supports } \\
\text { Al growth; inhibits apoptosis }\end{array}$ & May be increased & $\begin{array}{l}\text { Phosphorodiamidate morpholino } \\
\text { oligomers against c-Myc in early trials a }\end{array}$ & 82,73 \\
\hline$N F \kappa B$ & $\begin{array}{l}\text { Causes transcription of multiple factors involved } \\
\text { in angiogenesis, metastasis, and antiapoptosis }\end{array}$ & Increased & $\begin{array}{l}\text { Proteasome inhibitor bortezumib } \\
\text { opposes degradation of } \mathrm{I}_{k} \mathrm{~B}^{\mathrm{a}}\end{array}$ & 71 \\
\hline
\end{tabular}

aStudies in human subjects available for review. Abbreviations: $\mathrm{Al}$, androgen independent; AP-1, activating protein 1; AR, androgen receptor; CaP, prostate cancer, IkB, inhibitor of $\kappa B$; NFאB, nuclear factor $\mathrm{kB}$.

Table 10 Castration-induced changes in miscellaneous factors possibly involved in androgen receptor-independent prostate cancer progression.

\begin{tabular}{|c|c|c|c|c|}
\hline Factor & CaP related physiology & Castration related changes & Potential clinical role & $\begin{array}{l}\text { Selected } \\
\text { references }\end{array}$ \\
\hline Arachidonic acid & $\begin{array}{l}\text { Increased by EGF/neurotensin } \\
\text { signaling }\end{array}$ & $\begin{array}{l}\text { Possible upregulation if NE cells } \\
\text { switch to GF pathways }\end{array}$ & $\begin{array}{l}\text { COX-2 inhibitors show modest } \\
\text { activity in early trials }\end{array}$ & 94 \\
\hline CD-117 (c-kit) & NR & Induced in 1 metastatic sample & NR & 64 \\
\hline $\operatorname{cox}-2$ & $\begin{array}{l}\text { Enzyme produces prostaglandins } \\
\text { from arachidonic acid }\end{array}$ & Increased & $\begin{array}{l}\text { COX-2 inhibitors show modest } \\
\text { activity in early trials }\end{array}$ & $83,94,95$ \\
\hline Id-1 & $\begin{array}{l}\text { Upregulates EGFR; inhibits } \\
\text { transcription factors }\end{array}$ & Increased & Future target & 96 \\
\hline Insulin receptor & Controls glucose balance & Increased & NR & 61 \\
\hline RPTPa & $\begin{array}{l}\text { Role in neuronal differentiation; } \\
\text { activates Src }\end{array}$ & Increased & $\begin{array}{l}\text { Marker for NED and correlation } \\
\text { with ERK1/2 activation }\end{array}$ & 72 \\
\hline SREBPs ${ }^{a}$ & $\begin{array}{l}\text { Regulate transcription of } \\
\text { enzymes involved in lipogenesis }\end{array}$ & Increased ${ }^{a}$ & NR & 97 \\
\hline $\begin{array}{l}\text { SREBP cleavage } \\
\text { protein }^{\mathrm{a}}\end{array}$ & Cleaves SREBPsa & $\begin{array}{l}\text { Initial decrease; increased upon } \\
\text { Al progression }\end{array}$ & NR & 97 \\
\hline
\end{tabular}

(e.g. vascular cell-adhesion molecule, intercellular cell-adhesion molecule and E-selectin), stress response (e.g. cyclooxygenase 2 [Table 10] and nitric oxide synthase), and factors inhibiting apoptosis (e.g. Bcl-2 family and inhibitorof-apoptosis proteins [Table 6]). ${ }^{47}$ These pathways are intimately involved in proliferation, angiogenesis, invasiveness, metastasis, and apoptosis inhibition. ${ }^{48}$ Recently, bortezomib, an inhibitor of the proteasome responsible for degrading IкB, has shown efficacy and tolerability in prostate cancer and might be a promising treatment in combination with other agents. ${ }^{49,50}$

\section{CURRENT TREATMENTS FOR ANDROGEN- INDEPENDENT PROSTATE CANCER}

Docetaxel was recently shown to modestly improve survival in androgen-independent prostate cancer. ${ }^{51,52}$ Most of the biologic agents discussed earlier in this review are currently undergoing testing in combination with docetaxel at the time of androgen-independent disease progression. This strategy shows some promise, as many of the biologic agents show modest activity alone, seeming to function better as chemosensitizers or radiosensitizers. ${ }^{12}$ By contrast, very few studies exist that examine 
Table 11 Castration-induced changes in prostate cancer markers in androgen receptor-independent prostate cancer progression.

\begin{tabular}{|c|c|c|c|c|}
\hline Factor & CaP related physiology & Castration related changes & Potential clinical role & $\begin{array}{l}\text { Selected } \\
\text { references }\end{array}$ \\
\hline $\mathrm{CgA}^{\mathrm{a}}$ & Marker $^{a}$ & Increase in plasma levels ${ }^{a}$ & Marker of NED & 98 \\
\hline $\mathrm{CgB}$ & Marker & 5-10 fold increase from NE cells & $\begin{array}{l}\text { Better marker than } \mathrm{CgA} \text { in } \\
\text { certain NED cancers }\end{array}$ & 72 \\
\hline KI67 (MIB-1) ${ }^{\mathrm{a}}$ & $\begin{array}{l}\text { Nuclear antigen; marker of cell } \\
\text { division }^{\mathrm{a}}\end{array}$ & Decreased or no change $e^{a}$ & Marker for cell division ${ }^{a}$ & 34,64 \\
\hline NSE ${ }^{\mathrm{a}}$ & Markera & Variable ${ }^{a}$ & Prognostic marker ${ }^{a}$ & 72 \\
\hline PSA & Marker & $\begin{array}{l}\text { Decreased overall owing to cell } \\
\text { death; decreased expression by } \\
\text { NE cells }\end{array}$ & Prognostic marker & 72 \\
\hline PSP94a & Unknown ${ }^{2}$ & Persists during $A D T^{\mathrm{a}}$ & Marker of Al CaPa & 99 \\
\hline $\begin{array}{l}\text { Tissue } \\
\text { glutaminase }\end{array}$ & Marker for apoptosis ${ }^{a}$ & $\begin{array}{l}\text { Initial increase followed by } \\
\text { decrease }^{\mathrm{a}}\end{array}$ & Apoptosis marker ${ }^{a}$ & 100 \\
\hline
\end{tabular}

aStudies in human subjects available for review. Abbreviations: ADT, androgen deprivation therapy; Al, androgen independent; CaP, prostate cancer; CgA, chromogranin A; CgB, chromogranin B; MIB-1, ubiquitin ligase MIB-1 (mindbomb homolog 1); NE, neuroendocrine; NED, neuroendocrine differentiation; NSE, neuron specific enolase; PSA, prostate-specific antigen; PSP94, prostate-specific protein-94.

the adjunctive use of these biologic agents at the time of castration. We believe that the changes occurring at the time of castration set in motion events leading to androgen-independent prostate cancer, thus indicating a role for adjunctive therapy at that time. The rationale for adjunctive treatment for prostate cancer at the time of castration is based on several lines of evidence.

First, microenvironmental changes in the cellular milieu are likely to have a major role in the initiation of clinical disease. ${ }^{53}$ ADT induces further changes (listed in Tables 1-11), which, through poorly defined biochemical pathways, promote the emergence of androgen-independent prostate cancer. Future treatment strategies might target these microenvironmental cellular changes and attempt to reverse or ameliorate them through gene silencing (ASOs, small interfering RNA) or direct inactivation/activation of opposing factors (mAbs). Second, the apoptotic response to the act of castration is never complete, and efforts to enhance this response will decrease residual disease and possibly delay disease progression. Subsets of cells can have resistance to apoptosis through mutational changes in effectors (e.g. p53/p21) or through the chance occurrence of elevated precastration levels of antiapoptotic factors (e.g. Bcl family proteins or HSPs). Efforts, initiated at the time of castration, to increase the effectiveness of treatment and approximate a maximal apoptotic response should be attempted. Third, the smaller tumor burden associated with earlier treatment of prostate cancer potentially allows a greater chance for effective intervention. ${ }^{28}$ Finally, the biologic therapies discussed are attractive in that they generally have relatively low toxicity profiles, making them suitable adjunctive treatments for prostate cancer.

Of the many castration-induced changes listed in the tables presented in this review, mechanisms suggested for future study include those that are consistently seen in vivo and that have well-characterized and effective inhibitors available. Proteasome inhibition, targeted therapies such as PI3K inhibitors or Bcl-2 ASOs, and small molecule tyrosine kinase inhibitors all represent possible strategies for treating prostate cancer in the adjunctive setting. In addition, angiogenesis inhibitors and cellular adhesion modifications might decrease growth and metastasis as well as having direct intracellular effects on a variety of pathways.

\section{CONCLUSION}

Increasing the effectiveness of ADT and/or delaying the onset of androgen-independent prostate cancer represents a major treatment strategy for this disease. The biochemical changes demonstrated by prostate cancer cells undergoing castration suggest therapeutic methods for adjunctive treatment. Specific therapies currently exist that target many of these pathways. These should ultimately be tested in the adjunctive setting. 


\section{KEY POINTS}

- Although not completely understood, the progression of prostate cancer to an androgenindependent state probably involves multiple biochemical pathways

- Therapeutic androgen ablation is likely to be an initial factor driving this biochernical cascade of events

- Novel biologic agents are now available enabling modification of some of the pathways involved in the development of androgenindependent prostate cancer

- Current clinical data shows some efficacy for biologic agents when used with chemotherapy in the setting of androgen-independent disease

- Future trials should also test biologic agents at the time of androgen ablation to attempt to maximize the initial apoptotic response and delay the onset of androgen independence

\section{References}

1 Jemal A et al. (2006) Cancer statistics, 2006. CA Cancer J Clin 56: 106-130

2 Smaletz O et al. (2002) Nomogram for overall survival of patients with progressive metastatic prostate cancer after castration. J Clin Oncol 20: 3972-3982

3 Sharifi N and Farrar WL (2006) Androgen receptor as a therapeutic target for androgen independent prostate cancer. Am J Ther 13: 166-170

4 Feldman BJ and Feldman D (2001) The development of androgen-independent prostate cancer. Nat Rev Cancer 1: 34-45

5 So A et al. (2005) Mechanisms of the development of androgen independence in prostate cancer. World $J$ Urol 23: 1-9

6 Wu RC et al. (2005) Transcriptional regulation by steroid receptor coactivator phosphorylation. Endocr Rev 26: 393-399

7 Culig Z et al. (2004) Expression and function of androgen receptor coactivators in prostate cancer. J Steroid Biochem Mol Biol 92: 265-271

8 Gioeli D et al. (1999) Activation of mitogen-activated protein kinase associated with prostate cancer progression. Cancer Res 59: 279-284

9 Lorenzo GD et al. (2003) Involvement of growth factor receptors of the epidermal growth factor receptor family in prostate cancer development and progression to androgen independence. Clin Prostate Cancer 2: 50-57

10 Lara PN Jr et al. (2004) Trastuzumab plus docetaxel in HER-2/neu-positive prostate carcinoma: final results from the California Cancer Consortium Screening and Phase II Trial. Cancer 100: 2125-2131

11 Ziada A et al. (2004) The use of trastuzumab in the treatment of hormone refractory prostate cancer. phase II trial. Prostate 60: 332-337

12 van der Poel HG (2004) Smart drugs in prostate cancer. Eur Urol. 45: 1-17

13 Smith MR and Nelson JB (2005) Future therapies in hormone-refractory prostate cancer. Urology 65: 9-16; discussion 17

14 Canil CM et al. (2005) Randomized phase II study of two doses of gefitinib in hormone-refractory prostate cancer: a trial of the National Cancer Institute of Canada-Clinical Trials Group. J Clin Oncol 23: 455-460
15 Krueckl SL et al. (2004) Increased insulin-like growth factor I receptor expression and signaling are components of androgen-independent progression in a lineage-derived prostate cancer progression model. Cancer Res 64: 8620-8629

16 Miyake Het al. (2000) Castration-induced upregulation of insulin-like growth factor binding protein-5 potentiates insulin-like growth factor-I activity and accelerates progression to androgen independence in prostate cancer models. Cancer Res 60: 3058-3064

17 Klyama S et al. (2003) Castration-induced increases in insulin-like growth factor-binding protein 2 promotes proliferation of androgen-independent human prostate LNCaP tumors. Cancer Res 63: 3575-3584

18 Miyata Y et al. (2004) Expression of insulin-like growth factor binding protein-3 before and after neoadjuvant hormonal therapy in human prostate cancer tissues: correlation with histopathologic effects and biochemical recurrence. Urology 63: 1184-1190

19 Papandreou CN et al. (1998) Neutral endopeptidase 24.11 loss in metastatic human prostate cancer contributes to androgen-independent progression. Nat Med 4: 50-57

20 Lee LF et al. (2001) Neuropeptide-induced androgen independence in prostate cancer cells; roles of nonreceptor tyrosine kinases Etk/Bmx, Src, and focal adhesion kinase. Mol Cell Biol 21: 8385-8397

21 Amorino GP and Parsons SJ (2004) Neuroendocrine cells in prostate cancer. Crit Rev Eukaryot Gene Expr 14: $287-300$

22 Song L et al. (2006) Dasatinib (BMS-354825) selectively induces apoptosis in lung cancer cells dependent on epidermal growith factor receptor signaling for survival. Cancer Res 66: 5542-5548

23 Yang JC et al. (2005) Src kinase inhibition of neuropeptide-induced androgen-independent prostate cancer. Proc Amer Assoc Cancer Res 46: 3180

24 Nam S et al. (2005) Action of the Src family kinase inhibitor, dasatinib (BMS-354825), on human prostate cancer cells. Cancer Res 65: 9185-9189

25 McDonnell TJ et al. (1992) Expression of the protooncogene bcl-2 in the prostate and its association with emergence of androgen-independent prostate cancer. Cancer Res 52: 6940-6944

26 Colombel M et al. (1993) Detection of the apoptosissuppressing oncoprotein bc1-2 in hormone-refractory human prostate cancers. Am J Pathol 143: 390-400

27 Shi Y et al. (2006) Role of coordinated molecular alterations in the development of androgenindependent prostate cancer: an in vitro model that corroborates clinical observations. B.JU Int 97 : 170-178

28 Miyake $\mathrm{H}$ et al. (2001) Novel therapeutic strategy for advanced prostate cancer using antisense oligodeoxynucleotides targeting anti-apoptotic genes upregulated after androgen withdrawal to delay androgen-independent progression and enhance chemosensitivity. Int J Urol 8: 337-349

29 Tolcher AW et al. (2005) A phase II, pharmacokinetic, and biological correlative study of oblimersen sodium and docetaxel in patients with hormone-refractory prostate cancer. Clin Cancer Res 11: 3854-3861

30 Gleave $\mathrm{M}$ et al. (2005) Beyond simple castration: targeting the molecular basis of treatment resistance in advanced prostate cancer. Cancer Chemother Pharmacol 56 (Suppl 1): 47-57

31 July LV et al. (2002) Clusterin expression is significantly enhanced in prostate cancer cells following androgen withdrawal therapy. Prostate 50: 179-188

32 Miyake $\mathrm{H}$ et al. (2005) Antisense oligodeoxynucleotide therapy targeting clusterin gene for prostate cancer: Vancouver experience from discovery to clinic. Int $J$ Urol 12: 785-794 
33 Chi KN tat. (2005) A phase I pharmacokinetic and pharmacodynamic study of OGX-011, a 2 '-methoxyethyl antisense oligonucleotide to clusterin, in patients with localized prostate cancer. J Natl Cancer inst 97: 1287-1296

34 Baretton GB et al. (1999) Proliferation- and apoptosis-associated factors in advanced prostatic carcinomas before and after androgen deprivation therapy: prognostic significance of p21/WAF1/CIP1 expression. Br J Cancer 80: 546-555

35 Wikstrom P et al. (1999) Early castration-induced upregulation of transforming growth factor beta1 and its receptors is associated with tumor cell apoptosis and a major decline in senum prostate-specific antigen in prostate cancer patients. Prostate 38: 268-277

36 Chevalier S et al. (2002) Vascular endothelial growth factor and signaling in the prostate: more than angiogenesis. Mol Cell Endocrinol 189: 169-179

37 George DJ et al. (2001) Prognostic significance of plasma vascular endothelial growth factor levels in patients with hormone-refractory prostate cancer treated on Cancer and Leukemia Group B 9480. Clin Cancer Res 7: 1932-1936

38 Lara PN Jr et al. (2004) Angiogenesis-targeted therapies in prostate cancer. Clin Prostate Cancer 3: 165-173

39 Picus J et at. (2003) The use of bevacizumab (B) with docetaxel (D) and estramustine (E) in hormone refractory prostate cancer (HRPC): Initial results of CALGB 90006. Proc Am Soc Clin Oncol 22: 393

40 Schlaepfer DD and Hunter T (1998) Integrin signalling and tyrosine phosphorylation: just the FAKs? Trends Cell Biol $8:$ 151-157

41 Danen EH and Yamada KM (2001) Fibronectin, integrins, and growth control. J Cell Physiol 189: $1-13$

42 Stewart DA et al. (2004) Changes in extracellular matrix (ECM) and ECM-associated proteins in the metastatic progression of prostate cancer. Reprod Biol Endocrinol 2: 2

43 Stubbs AP et al. (1999) Differentially expressed genes in hormone refractory prostate cancer: association with chromosomal regions involved with genetic aberrations. Am J Pathof 154: 1335-1343

44 Legrier ME et al. (2004) Mucinous differentiation features associated with hormonal escape in a human prostate cancer xenograft. Br J Cancer 90: 720-727

45 North SA et al. (2006) A pilot study of the liposomal MUC1 vaccine BLP25 in prostate specific antigen failures after radical prostatectomy. J Urol 176: 91-95

46 Kousidou O et al. (2006) Effects of the natural isoflavonoid genistein on growth, signaling pathways and gene expression of matrix macromolecules by breast cancer cells. Mini Rev Med Chem 6: 331-337

47 Papandreou CN and Logothetis CJ (2004) Bortezomib as a potential treatment for prostate cancer. Cancer Res 64: 5036-5043

48 Orlowski RZ and Baldwin AS Jr (2002) NF-kappaB as a therapeutic target in cancer. Trends Mol Med \&: 385-389

49 Price $\mathrm{N}$ and Dreicer R (2004) Phase I/II trial of bortezomib plus docetaxel in patients with advanced androgen-independent prostate cancer. Clin Prostate Cancer 3: 141-143

50 Papandreou CN et al. (2004) Phase I trial of the proteasome inhibitor bortezomib in patients with advanced solid tumors with observations in androgen-independent prostate cancer. J Clin Oncol 22: 2108-2121

51 Petrylak DP et al. (2004) Docetaxel and estramustine compared with mitoxantrone and prednisone for advanced refractory prostate cancer. $N$ Engl $J$ Med 351: 1513-1520
52 Tannock IF et al. (2004) Docetaxel plus prednisone or mitoxantrone plus predinisone for advanced prostate cancer. N Engl J Med 351: 1502-1512

53 Chung LW et af, (2005) Molecular insights into prostate cancer progression: the missing link of tumor microenvironment. J Urol 173: 10-20

54 Gregory CW et al. (1998) Androgen receptor expression in androgen-independent prostate cancer is associated with increased expression of androgenregulated genes. Cancer Res 58: 5718-5724

55 Hong $\mathrm{H}$ et al. (2004) Aberrant expression of CARM1, a transcriptional coactivator of androgen receptor, in the development of prostate carcinoma and androgen-independent status. Cancer 101: 83-89

56 Debes JD et at. (2002) p300 mediates androgenindependent transactivation of the androgen receptor by interleukin 6. Cancer Res 62: 5632-5636

57 Halkidou $\mathrm{Ket}$ al. (2003) Expression of Tip60, an androgen receptor coactivator, and its role in prostate cancer development. Oncogene 22: 2466-2477

58 Culig $\mathrm{Z}$ et al. (1994) Androgen receptor activation in prostatic tumor cell lines by insulin-like growth factor-1, keratinocyte growth factor, and epidermal growth factor. Cancer Res 54: 5474-5478

59 Dorkin TJ et al. (1999) aFGF immunoreactivity in prostate cancer and its co-localization with bFGF and FGF8. J Pathol 189: 564-569

60 Sirotnak FM et al. (2004) Microarray analysis of prostate cancer progression to reduced androgen dependence: studies in unique models contrasts early and late molecular events. Mol Carcinog 41: 150-163

61 Bubendorf L et al. (1999) Hormone therapy failure in human prostate cancer: analysis by complementary DNA and tissue microarrays. J Natt Cancer Inst 91: 1758-1764

62 Stewart RJ et al. (2001) Vascular endothelial growth factor expression and tumor angiogenesis are regulated by androgens in hormone responsive human prostate carcinoma: evidence for androgen dependent destabilization of vascular endothelial growth factor transcripts. J Urol 165: 688-693

63 Aslan G et al. (2005) Vascular endothelial growth factor expression in untreated and androgen-deprived patients with prostate cancer. Pathol Res Pract 201: 593-598

64 Zellweger T et al. (2005) Expression patterns of potential therapeutic targets in prostate cancer. Int $J$ Cancer 113: 619-628

65 Naimi B et al. (2002) Down-regulation of (lllb) and (IIIc) isoforms of fibroblast growth factor receptor 2 (FGFR2) is associated with malignant progression in human prostate. Prostate 52: 245-252

66 Dizeyi $\mathrm{N}$ et al. (2005) Expression of serotonin receptors $2 \mathrm{~B}$ and 4 in human prostate cancer tissue and effects of their antagonists on prostate cancer cell lines. Eur Urol 47: 895-900

67 Jongsma $\mathrm{J}$ et al. (2000) Androgen deprivation of the PC-310 [correction of prohormone convertase-310] human prostate cancer model system induces neurcendocrine differentiation. Cancer Res 60: 741-748

68 Salido M et al. (2002) Neuropeptides bombesin and calcitonin inhibit apoptosis-related elemental changes in prostate carcinoma cell lines. Cancer 94: 368-377

69 Takahashi W et al. (2003) Regulatory effect of castration on endothelins, their receptors and endothelin-converting enzyme in rat seminal vesicle. BJU int 92: 803-809

70 Yashi M et al. (2003) Elevated serum progastrinreleasing peptide (31-98) level is a predictor of short response duration after hormonal therapy in metastatic prostate cancer. Prostate 56: 305-312

71 Levine L et af. (2003) Bombesin stimulates nuclear factor kappa $\mathrm{B}$ activation and expression of 


\section{Acknowledgments}

Research supported in part

by NIH grant KOB DK60748.

01 and Department of

Defense grant PC040161.

\section{Competing interests}

The authors declared

they have no competing

interests. proangiogenic factors in prostate cancer cells. Cancer Res 63: 3495-3502

72 Yuan TC et al. (2006) Androgen deprivation induces human prostate epithelial neuroendocrine differentiation of androgen-sensitive LNCaP cells. Endocr Relat Cancer 13: 151-167

73 Vashchenko $\mathrm{N}$ and Abrahamsson PA (2005) Neuroendocrine differentiation in prostate cancer: implications for new treatment modalities. Eur Urol 47: 147-155

74 Gutierrez-Canas I et al. (2005) Vasoactive intestinal peptide induces neuroendocrine differentiation in the LCaP prostate cancer cell line through PKA, ERK, and PI3K. Prostate 63: 44-55

75 Sugihara A et al. (1998) Expression of cytokines enhancing the osteoclast activity, and parathyroid hormone-related protein in prostatic cancers before and after endocrine therapy: an immunohistochemical study. Oncol Rep 5: 1389-1394

76 Wise GJ et al. (2000) Cytokine variations in patients with hormone treated prostate cancer. J Urol 164: 722-725

77 Lee LF et al. (2004) Interleukin-8 confers androgenindependent growth and migration of $\mathrm{LNCaP}$. differential effects of tyrosine kinases Src and FAK. Oncogene 23: 2197-2205

78 Huerta-Yepez S et al. (2006) Involvement of the TNF-alpha autocrine-paracrine loop, via NF-kappaB and $Y Y 1$, in the regulation of turnor cell resistance to Fas-induced apoptosis. Clin immunol 120: 297-309

79 Watson RW and Fitzpatrick JM (2005) Targeting apoptosis in prostate cancer: focus on caspases and inhibitors of apoptosis proteins. BJU Int 96 (Suppl 2): $30-34$

80 Koivisto PA and Rantala I (1999) Amplification of the androgen receptor gene is associated with P53 mutation in hormone-refractory recurrent prostate cancer. J Pathol 187: 237-241

81 Pflug BR et al. (1999) Caveolin expression is decreased following androgen deprivation in human prostate cancer cell lines. Prostate 40: 269-273

82 Persad S and Dedhar S (2003) The role of integrinlinked kinase (ILK) in cancer progression. Cancer Metastasis Rev 22: 375-384

83 Miyamoto $\mathrm{H}$ et al. (2005) Inhibition of the Akt, cyclooxygenase-2, and matrix metalloproteinase- 9 pathways in combination with androgen deprivation therapy: potential therapeutic approaches for prostate cancer. Mol Carcinog 44: 1-10

84 Kiviniemi J et al. (2004) Altered expression of syndecan-1 in prostate cancer. Apmis 112: 89-97

85 Lokeshwar BL (1999) MMP inhibition in prostate cancer. Ann N Y Acad Sci 878: 271-289

86 Bratland A et al. (2003) The metalloproteinase inhibitor TIMP-2 is down-regulated by androgens in LNCaP prostate carcinoma cells, Clin Exp Metastasis 20: 541-547

87 Nishiyama T et al. (2004) The influence of androgen deprivation therapy on dihydrotestosterone levels in the prostatic tissue of patients with prostate cancer. Clin Cancer Res 10: 7121-7126

88 Lei Q et al. (2006) NKX3.1 stabilizes p53, inhibits AKT activation, and blocks prostate cancer initiation caused by PTEN loss. Cancer Cell 9: 367-378

89 Majumder PK and Sellers WR (2005) Akt-regulated pathways in prostate cancer. Oncogene 24: 7465-7474

90 Edwards J et al. (2004) The role of c-Jun and c-Fos expression in androgen-independent prostate cancer. $J$ Pathol 204: 153-158

91 Aprikian AG et al. (1996) Bombesin specifically induces intracellular calcium mobilization via gastrinreleasing peptide receptors in human prostate cancer cells. J Mol Endocrinol 16: 297-306

92 Sumitomo $\mathrm{M}$ et al. (2001) Neutral endopeptidase inhibits neuropeptide-mediated transactivation of the insulin-like growth factor receptor-Akt cell survival pathway. Cancer Res 61: 3294-3298

93 Devi GR et al. (2005) In vivo bioavailability and pharmacokinetics of a c-MYC antisense phosphorodiamidate morpholino oligomer, AVI-4126, in solid tumors. Clin Cancer Res 11: 3930-3938

94 Smith MR et af. (2006) Celecoxib versus placebo for men with prostate cancer and a rising serum prostatespecific antigen after radical prostatectomy and/or radiation therapy. J Clin Oncol 24: 2723-2728

95 Pruthi RS et al. (2003) Cyclooxygenase-2 as a potential target in the prevention and treatment of genitourinary tumors: a review. J Urol 169: 2352-2359

96 Ling MT et al. (2004) Id-1 expression induces androgen-independent prostate cancer cell growth through activation of epidermal growth factor receptor (EGF-R). Carcinogenesis 25: 517-525

97 Ettinger SL et al. (2004) Dysregulation of sterol response element-binding proteins and downstream effectors in prostate cancer during progression to androgen independence. Cancer Res 64: 2212-2221

98 Sasaki T et al. (2005) Changes in chromogranin a serum levels during endocrine therapy in metastatic prostate cancer patients. Fur Urol 48: 224-229; discussion 229-230

99 Imasato $Y$ et al. (2000) PSP94 expression after androgen deprivation therapy: a comparative study with prostate specific antigen in benign prostate and prostate cancer. J Urol 164: 1819-1824

100 Rittmaster RS et al. (1999) The utility of tissue transglutaminase as a marker of apoptosis during treatment and progression of prostate cancer. J Urol 162: 2165-2169 


\title{
REVIEW
}

\section{Inhibition of Akt pathways in the treatment of prostate cancer}

\author{
EC Nelson ${ }^{1}$, CP Evans ${ }^{1,2}$, PC Mack ${ }^{2}$, RW Devere-White ${ }^{1,2}$ and PN Lara Jr ${ }^{2}$ \\ ${ }^{1}$ Department of Urology, University of California at Davis, Sacramento, CA, USA and ${ }^{2}$ Cancer Center, University of California \\ at Davis, Sacramento, CA, USA
}

\begin{abstract}
Akt is a serine/threonine kinase mediating multiple intracellular pathways involved in prostate cancer (CaP) biology. Increased understanding of the molecular mechanisms of Akt activation and signaling have led to the development of an increasing number of Akt inhibitors. These biologic agents demonstrate activity against a wide range of cancers in preclinical studies. Clinical studies of Akt inhibition in $\mathrm{CaP}$ are in progress, including agents such as celecoxib, perifosine and genistein. How best to integrate Akt inhibitors with standard CaP therapy or select patients most likely to benefit is the subject of ongoing research.

Prostate Cancer and Prostatic Diseases (2007) 10, 331-339; doi:10.1038/sj.pcan.4500974; published online 1 May 2007
\end{abstract}

Keywords: akt; celecoxib; genistein; perifosine; protein kinase B

\section{Introduction}

Akt, or protein kinase $B$, is a serine/threonine kinase that plays an important role in intracellular signaling cascades. A variety of neoplasms show perturbations in the biochemical pathways affected by Akt. Prostate cancer $(\mathrm{CaP})$ specifically shows biochemical abnormalities related to Akt that may be of importance in sustaining tumor growth by preventing apoptosis and promoting proliferation and angiogenesis.

$\mathrm{CaP}$ is the most common noncutaneous malignancy in American males and is predicted to be the third leading cause of cancer deaths for 2006. ${ }^{1}$ While local therapy for $\mathrm{CaP}$ is relatively effective, androgen deprivation therapy remains the mainstay of treatment for disseminated disease and is principally palliative in nature. Introduced in the $1940 \mathrm{~s}^{2}{ }^{2}$ androgen deprivation removes androgen stimulation, initially inducing apoptosis in CaP. However, the disease eventually progresses to an androgen independent (AI) state with an associated life expectancy of only 15-20 months. Androgen deprivation, while extending length and quality of life for many patients, also induces tumor-specific biochemical changes of many intracellular factors including Akt. These changes may promote progression to an AI state. ${ }^{3}$

Novel treatments for $\mathrm{AI} \mathrm{CaP}$ are needed. Increasing understanding of the many biochemical changes associated with neoplastic progression and androgen independence has led to the identification of novel targets for therapeutic intervention. In this review, we discuss

Correspondence: Dr PN Lara Jr, Division of Hematology/Oncology, Department of Internal Medicine, School of Medicine, University of California, Davis, 4501 X Street, Sacramento, CA 95817, USA.

E-mail: primo.lara@ucdmc.ucdavis.edu

Received 17 January 2007; revised 29 March 2007; accepted 30 March 2007; published online 1 May 2007 pathways relating directly to Akt, focusing on those showing the greatest relevance to current and possible future therapeutic strategies.

\section{Pathways affected by Akt}

\section{Akt form and function}

Akt was originally identified as an oncogene within the AKT8 retrovirus. This retrovirus was isolated from the AKR strain of mice that have a high incidence of leukemia and lymphoma. ${ }^{4}$ Subsequent genetic analysis demonstrated that Akt is an important intracellular signaling moiety highly conserved across species. A member of the AGC kinase family, it is very similar to protein kinase $\mathrm{A}$ and protein kinase $\mathrm{C}$. When first discovered, it was therefore named 'protein kinase B' and is sometimes called RAC (related to A and C).

In humans, Akt is a family of three homologous members out of which Akt1 and Akt2 are more widely distributed than Akt3. ${ }^{5}$ Akt has three domains with specific functions. The N-terminal domain is a pleckstrin homology $(\mathrm{PH})$ domain, which can bind phosphoinositides (PI) in the cellular membrane. The C-terminal domain is a regulatory domain and the central portion of the protein is the catalytic domain. ${ }^{6}$ Complete activation of the catalytic activity of Akt requires phosphorylation of a threonine residue at 308 and a serine residue at 473 . It is possible that Akt shows partial activation with phosphorylation at the threonine 308 position. ${ }^{7}$

\section{Akt activation}

Akt activation occurs in response to multiple extracellular signals acting through tyrosine kinase and Gprotein coupled receptors (see Figure 1). These receptor types activate phosphoinositol-3-kinase (PI3K) class IA 


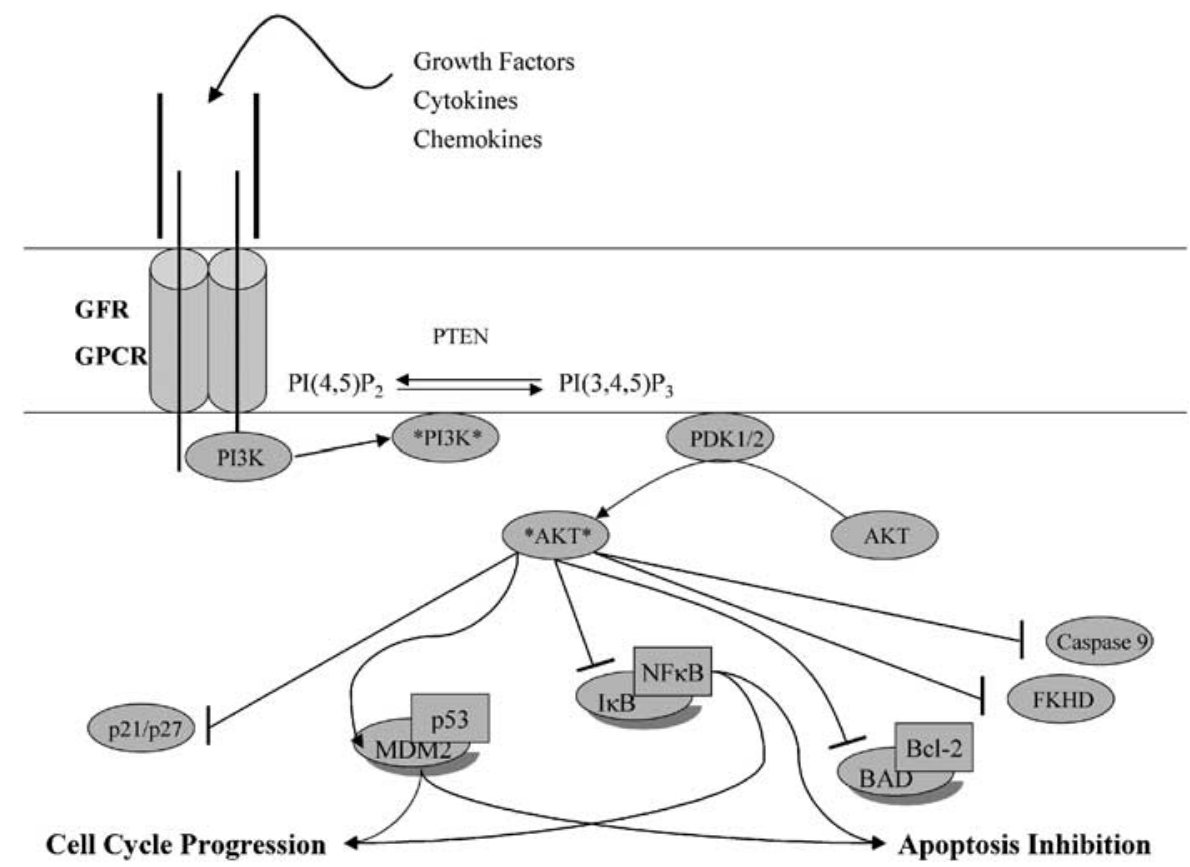

Figure 1 Simplified diagram of Akt activation and selected downstream effector pathways. Multiple extracellular signaling factors activate intracellular receptor domains. Activated PI3K promotes the $3^{\prime}$ phosphorylation of PI $(4,5) \mathrm{P}_{2}$. The resulting PI $(3,4,5) \mathrm{P}_{3}$ recruits Akt and PDK1 to the cell membrane through interactions with their PH domains. Akt is activated by phosphorylation resulting in multiple downstream effects. Abbreviations: GFR, growth factor receptor; GPCR, G-protein coupled receptor; NF $\kappa$ B, nuclear factor kappa B; PDK, phosphoinositidedependent kinase-1; PI3K, phosphoinositide-3-kinase; $\mathrm{PI}(3,4,5) \mathrm{P}_{3}$, phosphatidylinositol-3,4,5-trisphosphate; PI(4,5) $\mathrm{P}_{2}$, phosphatidylinositol4,5-bisphosphate; PTEN, phosphatase and tensin homolog deleted on chromosome 10.

and IB, respectively. In turn, PI3K phosphorylates the membrane phospholipid, phosphatidylinositol-4,5-bisphosphonate $\left(\mathrm{PI}(4,5) \mathrm{P}_{2}\right)$, which then acts as the secondmessenger phosphatidylinositol-3,4,5-trisphosphonate $\left(\mathrm{PI}(3,4,5) \mathrm{P}_{3}\right)$ for a variety of pathways. This event promotes recruitment of Akt from the cytoplasm to the cellular membrane where phosphoinositide-dependent kinase-1 (PDK1) phosphorylates the threonine 308 position of Akt. Phosphorylation of the serine 473 position also occurs, although the kinase responsible has not been definitively identified. This step appears to be tightly regulated and may require multiple intracellular messengers including integrin-linked kinase, PDK2 and others. $^{7}$

\section{Upstream inhibitors}

An intricate web of inhibitory factors opposing the actions of PI3K and subsequent second messengers control regulation of Akt activation. Most notably, 'phosphatase and tensin homolog deleted on chromosome 10' (PTEN) directly opposes PI3K by removing the $3^{\prime}$-phosphate from $\mathrm{PI}(3,4,5) \mathrm{P}_{3}$. A recently discovered class of phosphatases called SHIP phosphatases also may play a role in controlling levels of $\mathrm{PI}(3,4,5) \mathrm{P}_{3}$, and thus subsequent Akt activation. However it appears that as SHIP removes the 5-phosphate from $\mathrm{PI}(3,4,5) \mathrm{P}_{3}$, the resultant $\mathrm{PI}(3,4) \mathrm{P}_{2}$ may still recruit Akt to the plasma membrane. Therefore, PTEN is probably the more important inhibitor. ${ }^{5}$ Other recently discovered phosphatases include C-terminal modulator protein and $\mathrm{PH}$ domain leucine-rich repeat protein phosphatase, both of which may be significant in Akt regulation. ${ }^{8}$
Direct deactivation of Akt is also possible. Protein phophatases (PP1 and PP2a) both govern the regulatory activity of many intracellular messengers including Akt through dephosphophorylation. The complex activity of these regulatory proteins is controlled through cell wall constituents including palmitate, integrin and caveolin. ${ }^{5}$ Heat shock protein 90 may oppose the actions of these phosphatases, thereby promoting Akt activity. ${ }^{9}$

\section{Akt downstream effects}

Following activation, Akt moves from the cellular membrane to the cytoplasm where it exercises broad control over a variety of intracellular pathways generally supporting survival, proliferation, and other activities necessary for neoplastic disease progression.

Apoptosis and the cell cycle. Cancer cells escape normal biochemical systems regulating the balance between apoptosis and survival. Akt generally acts to promote survival through inhibition of proapoptotic factors and activation of anti-apoptotic factors. For example, the Bcl2 family of proteins consists of both proapoptotic and anti-apoptotic factors, the balance of which is critical for maintaining cellular homeostasis. Through phosphorylation, Akt inhibits the activity of proapoptotic members such as BAD, BAX and BID while activating antiapoptotic members such as Bcl-xL. ${ }^{10-12}$

Another family of apoptotic regulators is the forkhead family. In general, Akt phosphorylates various members of this family causing translocation from the nucleus to 
the cytoplasm, thus inhibiting the transcription of proapoptotic genes. ${ }^{7}$

Other biochemical pathways affected include apoptosis-signal-regulating kinase cyclic AMP response element binding protein, and the oncoprotein MDM2. Effects through these include inhibition of jun $\mathrm{N}$ terminal kinase and p53. In addition, Akt may block apoptosis after it has been initiated. For example, Akt can prevent the activation of caspase- 9 despite mitochondrial cytochrome $c$ release. ${ }^{5}$

Cancer cells also escape normal cellular controls over the cell cycle, generally resulting in increased, deregulated proliferation. Akt activation may promote this process through multiple pathways. Three central regulators of the cell cycle affected by Akt are cyclin D, p21 and p27. Cyclin D is necessary for cyclin-dependent kinase (CDK) activity regulating entry into the cell cycle. p21 and p27 are CDK inhibitors, which oppose cell-cycle progression. Akt phosphorylates and inactivates p21 and p27 thereby eliminating a critical negative regulator of CDK activity and promoting progression through the cell cycle. ${ }^{5}$

\section{Other/multiple pathways}

Other necessary cellular characteristics for neoplastic growth include angiogenesis, invasion and metastasis. Biochemical pathways affected by Akt may accomplish these effects with significant changes noted when Akt signaling intensity changes. In addition, three pathways discussed here have multiple or complex effects.

Akt activation may lead to increased angiogenesis through phosphorylation of endothelial nitric oxide synthase and subsequent production of nitric oxide. ${ }^{13,14}$ In addition, Akt is a key activator of the mammalian target of rapamycin (mTOR) which, through stabilization of the hypoxia inducible factor, induces expression of pro-angiogenic genes such as vascular endothelial growth factor. mTOR also promotes cell survival and proliferation through other pathways. Examples of these include activation of p70 ribosomal S6 kinase and inhibition of 4E-BP1, thus promoting ribosomal translation in general, and increased expression of cyclin D, which promotes cellular cycling and proliferation. ${ }^{5}$

One cellular pathway affected by Akt with multiple effects is the nuclear factor kappa-B $(\mathrm{NF} \kappa \mathrm{B})$ pathway. Akt causes the $\mathrm{NF} \kappa \mathrm{B}$ binding protein, $\mathrm{I} \kappa \mathrm{B}$, to release $\mathrm{NF} \kappa \mathrm{B}$, which then translocates to the nucleus where it transcribes multiple genes involved with proliferation, inflammation, cell adhesion, stress response and antiapoptosis. ${ }^{15} \mathrm{NF} \kappa \mathrm{B}$ also increases expression of matrix metalloproteinases, which are frequently elevated in $\mathrm{CaP}$ specimens and may play a role in promoting invasion and metastasis.

p53 is a tumor suppressor showing aberrant regulation or mutation in many neoplasms. Akt may play a role in regulating its activity through activation of its binding protein, MDM2. Phosphorylation of MDM2 causes translocation to the nucleus where it inactivates p53 resulting in cell-cycle progression and inhibition of apoptosis. $^{16}$

Of special interest in $\mathrm{CaP}$ is the observation that Akt can directly phosphorylate the androgen receptor on serine residues at positions 210 and 790. The results of this are controversial with some authors reporting activation while others report suppression of androgen receptor signaling. ${ }^{17,18}$ The reason for this may relate to different cell passage numbers, which is an interesting concept in the context of a rapidly dividing neoplasm. ${ }^{19}$

\section{Alterations of Akt activity in CaP}

Increased Akt activity in CaP may be caused by genetic overexpression of Akt or altered expression of its upstream-positive and upstream-negative regulators. In $\mathrm{CaP}$, several such mechanisms are probably active.

Akt overexpression has been demonstrated in $\mathrm{CaP}^{20}$ However, the most consistent finding in this disease is the silencing of PTEN and subsequent increase in Akt signaling. 8 PTEN may be lost by deletion, mutation or epigenetic mechanisms. ${ }^{5} \mathrm{Up}$ to half of the patients $\mathrm{CaP}$ tissue specimens show inactivation of PTEN with increasing incidence of this finding in metastatic deposits and AI disease, emphasizing its possible importance in tumor progression. ${ }^{21-23}$ Other genetic overexpression or underexpression of factors upstream of Akt have also been demonstrated in $\mathrm{CaP}$. Various growth factor receptors including the fibroblast growth factor, epidermal growth factor, and insulin-like growth factor are overexpressed in some $\mathrm{CaP}$ leading to increased Akt signaling. ${ }^{5}$ In addition, PI3K may be overexpressed in $\mathrm{CaP}^{5}$ and may be important in the progression to $\mathrm{AI}$ disease. $^{24}$

Regardless of the molecular mechanisms responsible, the excessive activation of Akt is a poor prognostic factor in $\mathrm{CaP}$. In one report, phosphorylation of Akt was superior to measurements of cellular proliferation and even Gleason grade for predicting biochemical recurrence following radical prostatectomy. ${ }^{25}$

Treatments for CaP may also upregulate Akt pathways through activation of cellular stress responses. In $\mathrm{CaP}$ specifically, androgen withdrawal may lead to biochemical changes ultimately supporting the emergence of AI disease. Although Akt itself may not be directly involved in causing this transition, some of these pathways signal through Akt. ${ }^{3,26}$ For example, emergence of a neuroendocrine phenotype in $\mathrm{CaP}$ may be important in disease progression. Such neuroendocrine cells may convert $\mathrm{CaP}$ cells to a dependence on survival signals through Gprotein coupled receptors and growth factor receptors upstream of Akt, bypassing the usual androgen receptor signaling. 26

These data cumulatively provide a rationale for Akt inhibition as a therapeutic paradigm in $\mathrm{CaP}$.

\section{Feedback mechanisms}

In light of the pathways and effects of Akt activation discussed above, it seems that Akt inhibition would naturally lead to positive therapeutic benefits in $\mathrm{CaP}$ and other neoplasms. Unfortunately, feedback mechanisms inherent in this complex biologic system may cause paradoxical responses to inhibition at various levels of Akt pathways. Two recently discovered feedback mechanisms demonstrate that inhibition of mTOR may, in fact, increase signaling through the Akt pathway. ${ }^{27}$ Although not yet demonstrated in vivo, the existence of such complexity demonstrates a clear need for future 
clinical trials to carefully measure the biologic effects of new therapies at the molecular level. Another factor complicating treatment using Akt inhibitors is one of the most important pathway for normal cellular physiology. It is not yet clear that developing treatment will demonstrate significant efficacy with acceptable levels of toxicity. These facts may lead to the use of Akt inhibition as adjunctive treatment rather than monotherapy.

\section{Akt inhibition as a therapeutic strategy}

Data demonstrating the importance of increased Akt signaling pathways in supporting prostatic growth and the neoplastic progression of $\mathrm{CaP}$ have stimulated efforts to modulate these pathways through direct and indirect Akt inhibition. In view of the increased activation of Akt during some treatments for $\mathrm{CaP}$, inhibition of Akt may be an important strategy for adjunctive therapy. Multiple inhibitors have been developed using a variety of mechanisms. Inhibition of PDK1 prevents activation of Akt and several effective agents are available (see Table 1). Direct inhibition of Akt may target any of the three domains discussed above using competitive, allosteric, pseudosubstrate or other mechanisms (see Table 2). Preclinical data on many Akt inhibitors are available and are reviewed in detail elsewhere. ${ }^{28-31}$ Additional data regarding the Akt inhibitory properties of several nutriceuticals is emerging and may prove important in the future. Examples include quercetin, ${ }^{32}$ diallyl trisulfide, ${ }^{33}$ curcumin $^{34}$ and silymarin. ${ }^{35}$ This review will be limited to agents for which clinical data are now available.

\section{Selective inhibitors of Akt}

\section{Celecoxib}

Celecoxib is a potent inhibitor of the inducible enzyme cyclooxygenase-2 (COX-2). By selective inhibition of COX-2 and avoidance of interference with the constitutively active COX-1, it was thought that celecoxib and other selective COX-2 inhibitors might be an effective treatment for inflammatory conditions while avoiding the gastric complications of long-term COX-1 inhibition. Although subsequent testing revealed an association with adverse cardiac outcomes leading to cessation of some ongoing trials, the drug remains on the market.

Celecoxib is currently of interest as preclinical experiments demonstrate significant proapoptotic effects in $\mathrm{CaP}$ cell lines. The biochemical activity of the drug is due to prevention of Akt phosphorylation by inhibiting the action of $P D K 1^{27,36}$ and this activity is independent of the COX-2 inhibitory effects. ${ }^{37}$ In addition, COX-2 inhibitors may have other cellular functions potentiating the apoptotic response. ${ }^{38} \mathrm{~A}$ therapeutic window for celecox$\mathrm{ib}$ might exist as the COX-2 enzyme is preferentially expressed in cancer tissue in response to tumor promoters, cytokines and growth factors. ${ }^{36}$ However, some experiments show expression of induced COX-2 in $\mathrm{CaP}$ to be low if present, especially compared to other epithelial malignancies. ${ }^{39}$ Although controversy exists on this point, COX-1 and -2 expression might be higher in the prostate in general regardless of disease processes. $^{40}$

Outcomes data up to 20 years ago indicated a cancer chemopreventive effect for anti-inflammatory medications. ${ }^{41}$ Large epidemiologic studies have examined this effect in celecoxib in a variety of cancers. ${ }^{42}$ Specifically, the rationale for $\mathrm{CaP}$ chemoprevention using $\mathrm{COX}-2$ inhibition was reviewed by Basler and Piazza. ${ }^{43}$ Although no current clinical chemoprevention data are available, the use of celecoxib as adjunctive therapy merits attention.

A phase II study by Pruthi et $a l .{ }^{44}$ of celecoxib monotherapy to modify prostate-specific antigen (PSA) doubling time (PSADT) in patients with biochemical relapse following definitive therapy has been reported. Forty patients were enrolled, ninteen of whom had a PSADT of less than 6 months. Following treatment, 36 of 40 patients showed a declining PSADT, and 11 of 40 had their PSA decline with an additional 8 of 40 showing stable PSA values. A following randomized, placebocontrolled trial of this effect was terminated early based on the question of celecoxib safety. An ad hoc analysis of existing data on 78 randomized patients revealed a greater than $200 \%$ increase in PSADT in $40 \%$ of patients receiving celecoxib compared to $20 \%$ receiving placebo $(P=0.08) .{ }^{45}$

Recent phase II studies demonstrate the use of celecoxib in combination with docetaxel and zolendronate. ${ }^{46,47}$ Both the studies demonstrated biochemical and objective tumor responses. Another randomized, blinded trial of celecoxib as neoadjuvant therapy before prostatectomy showed activity in the disease. Significant effects on cellular signaling, oxidative stress and cell-cycle regulation were apparent upon blinded in comparison of the pathology specimens. ${ }^{48}$

In summary, preclinical data suggest a role for celecoxib in the treatment of CaP. Its apoptotic effects are mediated through inhibition of Akt phosphorylation by antagonism of PDK1. A therapeutic window may allow efficacy and development of derivatives will further refine the specificity of this medication. ${ }^{27}$

Table 1 Select PDK-1 inhibitors

\begin{tabular}{|c|c|c|c|}
\hline Name & $I C_{50} / L$ & Comment & Selected citations \\
\hline Celecoxib & $3.5-48 \mu \mathrm{M}$ & COX-2 inhibitor & $36,37,72,73$ \\
\hline DMC & $38 \mu \mathrm{M}$ & Celecoxib analog w/o COX-2 activity & 73 \\
\hline OSU-03012/3 & $3 \mu \mathrm{M}$ & Celecoxib derivatives & 37 \\
\hline UCN-01 & $33 \mathrm{nM}$ & 7-hydroxy staurosporine analog, Phase I/II studies available & 55,74 \\
\hline $\mathrm{BX}-795,-912,-320$ & $11-30 \mathrm{nM}$ & Aminopyridines & 75 \\
\hline
\end{tabular}

Abbreviations: COX-2, cyclooxygenase-2; PDK, phosphoinositide-dependent kinase. 
Table 2 Select Akt inhibitors by class

\begin{tabular}{|c|c|c|c|}
\hline Name & $I C_{50}$ & Comments & $\begin{array}{l}\text { Selected } \\
\text { citations }\end{array}$ \\
\hline \multicolumn{4}{|l|}{ ATP competitive inhibitors } \\
\hline Balanol analogs & $4-5 \mathrm{nM}$ & Rationally designed & 76 \\
\hline $\mathrm{H}-89$ & $2.5 \mu \mathrm{M}$ & Protein kinase A inhibitor & 77 \\
\hline NL-71-101 & $3.7 \mu \mathrm{M}$ & Developed from H-89 & 78 \\
\hline \multicolumn{4}{|c|}{ Lipid-based/phosphatidylinositol analog inhibitors } \\
\hline PIA 5/6/23/24/25 & $<5 \mu \mathrm{M}$ & Ether lipid analogs, prevent translocation of Akt & $79-81$ \\
\hline Perifosine & $5 \mu \mathrm{M}$ & Prevents Akt translocation, phase II data available & 50 \\
\hline PX-316 & $1.7 \mu \mathrm{M}$ & Binds to PH domain of Akt & 82 \\
\hline PX-866 & $16.8 \mathrm{nM}$ & Inhibits PI signaling & \\
\hline \multicolumn{4}{|l|}{ Pseudosubstrate Inhibitors } \\
\hline AKTide-2T & $12 \mu \mathrm{M}$ & & 83,84 \\
\hline FOXO3 hybrid & $1.1 \mu \mathrm{M}$ & Hybrid with AKTide-2T & 30 \\
\hline FOXO3 hybrid modification & $0.11 \mu \mathrm{M}$ & Replaced Ser w Ala & 30 \\
\hline \multicolumn{4}{|c|}{ Allosteric inhibitors of AKT kinase domain } \\
\hline Compound 12 & $\begin{array}{l}\mathrm{AKT} 1=4.6 \mu \mathrm{M} \\
\mathrm{AKT} 2=>250 \mu \mathrm{M}\end{array}$ & First isozyme specific AKT inhibitor & 85,86 \\
\hline Compound 13 & $\begin{array}{l}\mathrm{AKT} 1=2.1 \mu \mathrm{M} \\
\mathrm{AKT} 2=21 \mu \mathrm{M}\end{array}$ & Dual activity & 85,86 \\
\hline Compounds $14-29$ & & Iterative improvements with greater specificity & 85,86 \\
\hline \multicolumn{4}{|l|}{ Akt antibodies } \\
\hline GST-anti-Akt1-MTS & & Cell-permeable antibody, blocks catalytic site & 87 \\
\hline \multicolumn{4}{|l|}{ Interaction with $\mathrm{PH}$ domain of $A K T$} \\
\hline Triciribine/API-2 & & $\begin{array}{l}\text { May interact with PH domain (?) Prior phase II trials at } \\
\text { high doses showed high toxicity }\end{array}$ & 88,89 \\
\hline TCN-P & & Triciribine monophosphate & 90 \\
\hline Akt-in & & Synthesized peptide & 84 \\
\hline \multicolumn{4}{|l|}{ Unknown/multiple mechanism(s) } \\
\hline KP372-1 & & & 91 \\
\hline $\begin{array}{l}\text { N10-substituted } \\
\text { phenoxazines }\end{array}$ & $1-2 \mu \mathrm{M}$ & May bind ATP-binding site or act as allosteric inhibitors & 92 \\
\hline Genistein & & Inhibits multiple intracellular kinases & $56,59,63$ \\
\hline
\end{tabular}

Abbreviation: $\mathrm{PH}$, pleckstrin homology.

\section{Perifosine}

Phospholipid analogues have been in use as medications for some time. Miltefosine demonstrated activity against many cancers and is still approved in Europe for use in cutaneous lymphoma and cutaneous breast cancer metastases. High rates of gastrointestinal toxicity and low bioavailability led to efforts to discover further modifications of phospholipid analogues with enhanced pharmaceutical potential.

Perifosine is a substituted alkylphosphocholine with oral bioavailability. In preclinical experiments, it causes cell-cycle arrest in $G_{1} / S$ or $G_{2} / M$, probably through effects mediated by p21 upregulation. ${ }^{49}$ These effects appear to occur through inhibition of Akt activation, although the mechanism is incompletely understood. As a phospholipid analogue, perifosine incorporates into the cell wall where it prevents Akt phosphorylation in a PDK1-independent manner. ${ }^{50}$ This apparently involves interference with the normal association of $\mathrm{PH}$ domains with 3-PI moieties.

Phase I trials established the tolerability of perifosine with most frequent side effects being nausea, vomiting and diarrhea. ${ }^{51,52}$ Two recent phase II trials of perifosine in $\mathrm{CaP}$ have been reported. A California Cancer
Consortium trial in 25 patients with biochemical recurrence following definitive therapy demonstrated biological and chemical activity, with $23 \%$ of patients having a decrease in PSA, although none were $>50 \% .^{53} \mathrm{~A}$ National Cancer Institute study of 19 men with metastatic AI CaP and average PSA of $180 \mathrm{ng} / \mathrm{ml}$ showed no objective or PSA responses, and four patients with PSA stabilization for 12 weeks. ${ }^{54}$

Although perifosine is apparently relatively ineffective as monotherapy, the strong preclinical rationale combined with preclinical results showing synergism with other Akt inhibitory drugs suggest the need for more trials examining its role in an adjunctive setting. ${ }^{55}$ Phase I trials are already underway for perifosine combined with docetaxel, paclitaxel, gemcitabine and radiation therapy. Future phase II trials at our institution will examine the combination of perifosine with other inhibitors of the Akt pathway in $\mathrm{CaP}$.

\section{Genistein}

Genistein is a naturally occurring isoflavone found in soy-based products. Gastric and intestinal hydrolytic reactions convert it to a well-absorbed aglyconic form. In 
addition, some Asian forms of fermented soy, such as miso, nattou and tempeh, are rich in isoflavone aglycones. Speculation regarding the $\mathrm{CaP}$-inhibitory effects of soy isoflavones exists because of significant epidemiologic differences in $\mathrm{CaP}$ incidence mirroring the consumption of, among other things, soy products. ${ }^{56}$ Preclinical data demonstrate truly remarkable biochemical characteristics of genistein. In many different cell lines and xenografts, the tyrosine kinase inhibitory characteristics of genistein induce apoptosis, cell-cycle arrest, hinders proliferation, prevents angiogenesis, and blocks androgen and estrogen-stimulated transcription. ${ }^{56-60}$ In addition, studies demonstrate genistein may oppose many cellular survival mechanisms induced by radiation, chemotherapy or androgen deprivation, suggesting the usefulness of this agent as adjunctive therapy. ${ }^{61,62}$

Subsequent analysis of these favorable biochemical changes reveal that many of them are mediated through Akt pathways (see Figure 1). For example, $\mathrm{NF} \kappa \mathrm{B}$, an upstream regulator of the apoptotic Bcl-2 family and the inhibitors of cyclin dependent kinases, p21 and p27, is activated by many cellular stimuli. $\mathrm{Li}$ and Sarkar ${ }^{63}$ demonstrated that $\mathrm{NF} \kappa \mathrm{B}$ activation in PC3 cells is mediated by Akt. In prostate cell lines, experiments at our institution confirm that genistein inhibits activation of Akt, thereby inducing apoptosis similar to other inhibitors of Akt (see Figure 2). ${ }^{64}$ Inhibitors such as LY294002, although completely blocking Akt phosphorylation through PI3K inhibition, are too toxic for human use. Genistein may provide a non-toxic alternative while maintaining sufficient activity to effect a clinical response.

Some of the cellular effects of genistein seen in vitro cannot be initiated at attainable concentrations in humans, even when consuming large amounts of soy. Concentrated aglycone-rich food supplements, such as genistein combined polysaccharide (GCP), may allow higher plasma levels of isoflavones. ${ }^{58}$ Recently, a prospective randomized study by Rannikko et al. ${ }^{65}$ found that prostate tissue concentrates phytoestrogens includ-
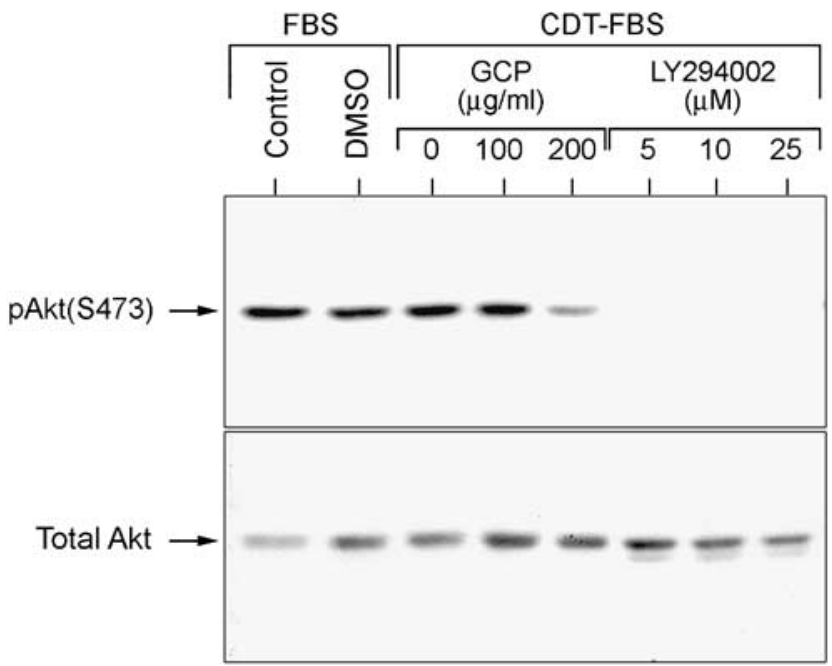

Figure 2 Western blot demonstrating the inhibition of Akt phosphorylation in the presence of GCP compared to LY294002 (Courtesy of Dr Clifford Tepper). GCP, genistein combined polysaccharide; DMSO, dimethylsulfoxide. ing genistein, thus suggesting that plasma concentrations underestimate tissue concentrations by over $50 \%$.

Given the promising preclinical data, studies are ongoing examining the activity of genistein in vivo against $\mathrm{CaP}$. Phase I studies demonstrate general tolerability. $^{66}$ A phase II pilot study at our institution examined the ability of GCP to decrease PSA in men with histologically proven $\mathrm{CaP}$. Sixty-two patients with elevated PSA were enrolled. Patients were categorized by prior treatment. Nine, seventeen and six had received prior prostatectomy, radiation therapy, or both, respectively. Fourteen were receiving intermittent hormone ablation and were currently off-cycle. Finally, 16 patients were on an active surveillance protocol. All patients received GCP supplements to be taken orally three times daily for 6 months. Three patients discontinued because of grade 2 diarrhea and seven patients discontinued for personal reasons. Of the 52 remaining patients, 8 had PSA reductions and 1 of them greater than $50 \%$. Interestingly, all of these patients were in the watchful waiting subgroup. In analysis of the responding patients vs others, there did not appear to be any correlation with Gleason score. In addition, estrogenic effects of genistein were probably not the causative factor as testosterone was increased in five responders, decreased in one, and unchanged in two. ${ }^{67}$

On the basis of these results, further randomized studies are currently ongoing at our institution. In addition to examination of GCP as monotherapy in patients on watchful waiting protocols, we plan to study GCP in conjunction with androgen deprivation therapy in patients with biochemical relapse following definitive therapy.

\section{Patient selection}

Biologic therapies modifying cellular signaling pathways generally show modest responses in most cases. This suggests the need to test such therapies in the adjunctive setting, possibly increasing the response to radiation, chemotherapy or androgen deprivation. ${ }^{3}$ For ethical reasons, many existing studies will use Akt inhibitors in conjunction with docetaxel-based chemotherapy. This is a rational strategy as chemotherapy upregulates survival pathways that involve Akt activity. ${ }^{68,69}$

Further efforts to predict patient response to biologic agents by pretreatment measurements of activated pathways through direct tissue or serum analysis may allow individualized treatment. One method involves profiling the entire proteome in patients' serum using matrix assisted laser desorption ionization-time-of-flight mass spectrometry. Multiple bioinformatics analyses of $\mathrm{CaP}$ patient serum and normal controls allows for proteomic 'fingerprints' with high discriminatory power. Once such profiles are produced, patients on clinical studies may be compared, allowing characterization of treatment effects on proteome profiles. Examination of the entire proteome may allow more efficient sorting of possible tumor markers. Eventually, exact identification of identified tumor markers is carried out by 2-D electrophoresis or liquid chromatography. ${ }^{70,71}$ In the future, biopsy samples analyzed for expression of such markers may allow ex vivo modeling of diseased pathways. Subsequent study 
will eventually lead to individualized and targeted biologic therapy.

\section{Conclusions}

Akt inhibition is a rational therapy in $\mathrm{CaP}$ treatment. Upregulation of this pathway is involved in initial neoplastic changes in some patients. An increasing number of patients show overexpression or overactivity of Akt as metastatic and AI diseases develop. Preclinical studies demonstrate the importance of this pathway in $\mathrm{CaP}$ and the possibility of targeting this pathway with any of an increasing number of inhibitors. In addition to preventing activation by blocking upstream signaling, strategies include allosteric inhibition, small molecule competitive inhibitors, pseudosubstrate inhibitors and others with multiple or unknown activity.

Clinical studies with agents known to act through Akt inhibition show some promise. Further studies examining vertical inhibition strategies to block Akt pathways more completely should be performed. More importantly, efforts to extend the activity of current therapeutic options through combination with Akt inhibitors and more accurate methods to select those patients most likely to benefit from Akt inhibition are needed.

\section{Acknowledgements}

PNL is supported in part by the Tom and Melissa Egan Cancer Research Fund, Veterans' Administration of Northern California, RO1-CA120469 and NIH NO1 CM17101.

\section{References}

1 Jemal A, Siegel R, Ward E, Murray T, Xu J, Smigal C et al. Cancer statistics, 2006. CA Cancer J Clin 2006; 56: 106-130.

2 Huggins C, Hodges C. Studies on prostate cancer: I. The effect of estrogen and of androgen injection on serum phosphatases in metastatic carcinoma of the prostate. Cancer Res 1941; 1: 293-297.

3 Nelson EC, Cambio AJ, Yang JC, Lara Jr PN, Evans CP. Biologic agents as adjunctive therapy prostate cancer: a rationale for use with androgen deprivation. Nat Clin Pract Urol 2007; 4: 82-94.

4 Staal SP, Hartley JW, Rowe WP. Isolation of transforming murine leukemia viruses from mice with a high incidence of spontaneous lymphoma. Proc Natl Acad Sci USA 1977; 74: 3065-3067.

5 Li L, Ittmann MM, Ayala G, Tsai MJ, Amato RJ, Wheeler TM et al. The emerging role of the PI3-K-Akt pathway in prostate cancer progression. Prostate Cancer Prostatic Dis 2005; 8: 108-118.

6 Coffer PJ, Jin J, Woodgett JR. Protein kinase B (c-Akt): a multifunctional mediator of phosphatidylinositol 3-kinase activation. Biochem J 1998; 335 (Part 1): 1-13.

7 Nicholson KM, Anderson NG. The protein kinase B/Akt signalling pathway in human malignancy. Cell Signal 2002; 14: 381-395.

8 Mulholland DJ, Dedhar S, Wu H, Nelson CC. PTEN and GSK3beta: key regulators of progression to androgen-independent prostate cancer. Oncogene 2006; 25: 329-337.

9 Sato S, Fujita N, Tsuruo T. Modulation of Akt kinase activity by binding to Hsp90. Proc Natl Acad Sci USA 2000; 97: 10832-10837.

10 Datta SR, Dudek H, Tao X, Masters S, Fu H, Gotoh Y et al. Akt phosphorylation of BAD couples survival signals to the cellintrinsic death machinery. Cell 1997; 91: 231-241.
11 Yamaguchi H, Wang HG. The protein kinase PKB/Akt regulates cell survival and apoptosis by inhibiting Bax conformational change. Oncogene 2001; 20: 7779-7786.

12 Majewski N, Nogueira V, Robey RB, Hay N. Akt inhibits apoptosis downstream of BID cleavage via a glucose-dependent mechanism involving mitochondrial hexokinases. Mol Cell Biol 2004; 24: 730-740.

13 Fulton D, Gratton JP, McCabe TJ, Fontana J, Fujio Y, Walsh K et al. Regulation of endothelium-derived nitric oxide production by the protein kinase Akt. Nature 1999; 399: 597-601.

14 Dimmeler S, Fleming I, Fisslthaler B, Hermann C, Busse R, Zeiher AM. Activation of nitric oxide synthase in endothelial cells by Akt-dependent phosphorylation. Nature 1999; 399: 601-605.

15 Papandreou CN, Logothetis CJ. Bortezomib as a potential treatment for prostate cancer. Cancer Res 2004; 64: 5036-5043.

16 Mayo LD, Donner DB. A phosphatidylinositol 3-kinase/Akt pathway promotes translocation of MDM2 from the cytoplasm to the nucleus. Proc Natl Acad Sci USA 2001; 98: 11598-11603.

17 Wen Y, Hu MC, Makino K, Spohn B, Bartholomeusz G, Yan DH et al. HER-2/neu promotes androgen-independent survival and growth of prostate cancer cells through the Akt pathway. Cancer Res 2000; 60: 6841-6845.

18 Lin HK, Yeh S, Kang HY, Chang C. Akt suppresses androgeninduced apoptosis by phosphorylating and inhibiting androgen receptor. Proc Natl Acad Sci USA 2001; 98: 7200-7205.

19 Lin HK, Hu YC, Yang L, Altuwaijri S, Chen YT, Kang HY et al. Suppression versus induction of androgen receptor functions by the phosphatidylinositol 3-kinase/Akt pathway in prostate cancer LNCaP cells with different passage numbers. J Biol Chem 2003; 278: 50902-50907.

20 Edwards J, Krishna NS, Witton CJ, Bartlett JM. Gene amplifications associated with the development of hormone-resistant prostate cancer. Clin Cancer Res 2003; 9: 5271-5281.

21 Rubin MA, Gerstein A, Reid K, Bostwick DG, Cheng L, Parsons $\mathrm{R}$ et al. 10q23.3 loss of heterozygosity is higher in lymph nodepositive $(\mathrm{pT} 2-3, \mathrm{~N}+)$ versus lymph node-negative (pT2-3,N0) prostate cancer. Hum Pathol 2000; 31: 504-508.

22 Wang S, Gao J, Lei Q, Rozengurt N, Pritchard C, Jiao J et al. Prostate-specific deletion of the murine PTEN tumor suppressor gene leads to metastatic prostate cancer. Cancer Cell 2003; 4: 209-221.

23 Majumder PK, Sellers WR. Akt-regulated pathways in prostate cancer. Oncogene 2005; 24: 7465-7474.

24 Murillo H, Huang H, Schmidt LJ, Smith DI, Tindall DJ. Role of PI3K signaling in survival and progression of LNCaP prostate cancer cells to the androgen refractory state. Endocrinology 2001; 142: 4795-4805.

25 Kreisberg JI, Malik SN, Prihoda TJ, Bedolla RG, Troyer DA, Kreisberg S et al. Phosphorylation of Akt (Ser473) is an excellent predictor of poor clinical outcome in prostate cancer. Cancer Res 2004; 64: 5232-5236.

26 Nelson EC, Cambio AJ, Yang JC, Ok J-H, Lara Jr PN, Evans CP. Clinical implications of neuroendocrine differentiation in prostate cancer. Prostate Cancer Prostatic Dis 2007; 10: 6-14.

27 Granville CA, Memmott RM, Gills JJ, Dennis PA. Handicapping the race to develop inhibitors of the phosphoinositide 3-kinase/ Akt/mammalian target of rapamycin pathway. Clin Cancer Res 2006; 12: 679-689.

28 Kim D, Cheng GZ, Lindsley CW, Yang H, Cheng JQ. Targeting the phosphatidylinositol-3 kinase/Akt pathway for the treatment of cancer. Curr Opin Investig Drugs 2005; 6: 1250-1258.

29 Chen YL, Law PY, Loh HH. Inhibition of PI3K/Akt signaling: an emerging paradigm for targeted cancer therapy. Curr Med Chem Anticancer Agents 2005; 5: 575-589.

30 Barnett SF, Bilodeau MT, Lindsley CW. The Akt/PKB family of protein kinases: a review of small molecule inhibitors and progress towards target validation. Curr Top Med Chem 2005; 5: 109-125.

31 Stauffer F, Holzer P, Garcia-Echeverria C. Blocking the PI3K/ PKB pathway in tumor cells. Curr Med Chem Anticancer Agents 2005; 5: 449-462. 
$32 \mathrm{Kim}$ YH, Lee YJ. TRAIL apoptosis is enhanced by quercetin through Akt dephosphorylation. J Cell Biochem 2007; 100: 998-1009.

33 Xiao D, Li M, Herman-Antosiewicz A, Antosiewicz J, Xiao H, Lew KL et al. Diallyl trisulfide inhibits angiogenic features of human umbilical vein endothelial cells by causing Akt inactivation and down-regulation of VEGF and VEGF-R2. Nutr Cancer 2006; 55: 94-107.

34 Deeb D, Jiang H, Gao X, Al-Holou S, Danyluk AL, Dulchavsky $\mathrm{SA}$ et al. Curcumin (diferuloyl-methane) sensitizes human prostate cancer cells to TRAIL/Apo2L-induced apoptosis by suppressing NF-\{kappa\}B via inhibition of pro-survival Akt signaling pathway. J Pharmacol Exp Ther 2007 [E-pub ahead of print].

35 Agarwal R, Agarwal C, Ichikawa H, Singh RP, Aggarwal BB et al. Anticancer potential of silymarin: from bench to bed side. Anticancer Res 2006; 26: 4457-4498.

36 Hsu AL, Ching TT, Wang DS, Song X, Rangnekar VM, Chen CS. The cyclooxygenase- 2 inhibitor celecoxib induces apoptosis by blocking Akt activation in human prostate cancer cells independently of Bcl-2. J Biol Chem 2000; 275: 11397-11403.

37 Zhu J, Huang JW, Tseng PH, Yang YT, Fowble J, Shiau CW et al. From the cyclooxygenase- 2 inhibitor celecoxib to a novel class of 3-phosphoinositide-dependent protein kinase-1 inhibitors. Cancer Res 2004; 64: 4309-4318.

38 Ding H, Han C, Zhu J, Chen CS, D'Ambrosio SM. Celecoxib derivatives induce apoptosis via the disruption of mitochondrial membrane potential and activation of caspase 9. Int J Cancer 2005; 113: 803-810.

39 Zha S, Gage WR, Sauvageot J, Saria EA, Putzi MJ, Ewing CM et al. Cyclooxygenase-2 is up-regulated in proliferative inflammatory atrophy of the prostate, but not in prostate carcinoma. Cancer Res 2001; 61: 8617-8623.

40 O'Neill GP, Ford-Hutchinson AW. Expression of mRNA for cyclooxygenase- 1 and cyclooxygenase- 2 in human tissues. FEBS Lett 1993; 330: 156-160.

41 Kune GA, Kune S, Watson LF. Colorectal cancer risk, chronic illnesses, operations, and medications: case-control results from the Melbourne Colorectal Cancer Study. Cancer Res 1988; 48: 4399-4404.

42 Kismet K, Akay MT, Abbasoglu O, Ercan A. Celecoxib: a potent cyclooxygenase- 2 inhibitor in cancer prevention. Cancer Detect Prev 2004; 28: 127-142.

43 Basler JW, Piazza GA. Nonsteroidal anti-inflammatory drugs and cyclooxygenase-2 selective inhibitors for prostate cancer chemoprevention. J Urol 2004; 171: S59-S62; discussion S53-S62.

44 Pruthi RS, Derksen JE, Moore D, Carson CC, Grigson G, Watkins $\mathrm{C}$ et al. Phase II trial of celecoxib in prostate-specific antigen recurrent prostate cancer after definitive radiation therapy or radical prostatectomy. Clin Cancer Res 2006; 12: 2172-2177.

45 Smith MR, Manola J, Kaufman DS, Oh WK, Bubley GJ, Kantoff PW. Celecoxib versus placebo for men with prostate cancer and a rising serum prostate-specific antigen after radical prostatectomy and/or radiation therapy. J Clin Oncol 2006; 24: 2723-2728.

46 Kasimis B, Cogswell J, Hwang S, Chang VT, Srinivas S, Zhong F et al. High dose celecoxib(C) and docetaxel(D) in patient$\mathrm{s}(\mathrm{pts})$ with hormone resistant prostate cancer(HRPC). Results of an ongoing phase II trial. J Clin Oncol 2005; 23S, Abstract 4704.

47 Kattan JG, Bachour M, Farhat F, El Seoudi M, Younes F, Ghosn M et al. Phase II trial of weekly docetaxel, zoledronate and celecoxib for androgen-independent prostate cancer patients. Proc Prostate Cancer Symp 2006; Abstract 362.

48 Sooriakumaran P, Macanas-Pirard P, Fox S, Coley H, Bucca G, Lovell $\mathrm{D}$ et al. A blinded, randomized controlled trial of neoadjuvant celecoxib in patients with early prostate cancer. J Clin Oncol 2006; 24S, Abstract 4563.

49 Patel V, Lahusen T, Sy T, Sausville EA, Gutkind JS, Senderowicz AM. Perifosine, a novel alkylphospholipid, induces p21(WAF1) expression in squamous carcinoma cells through a p53-independent pathway, leading to loss in cyclin-dependent kinase activity and cell cycle arrest. Cancer Res 2002; 62: 1401-1409.
50 Kondapaka SB, Singh SS, Dasmahapatra GP, Sausville EA, Roy KK. Perifosine, a novel alkylphospholipid, inhibits protein kinase B activation. Mol Cancer Ther 2003; 2: 1093-1103.

51 Crul M, Rosing H, de Klerk GJ, Dubbelman R, Traiser M, Reichert $\mathrm{S}$ et al. Phase I and pharmacological study of daily oral administration of perifosine (D-21266) in patients with advanced solid tumours. Eur J Cancer 2002; 38: 1615-1621.

52 Van Ummersen L, Binger K, Volkman J, Marnocha R, Tutsch K, Kolesar J et al. A phase I trial of perifosine (NSC 639966) on a loading dose/maintenance dose schedule in patients with advanced cancer. Clin Cancer Res 2004; 10: 7450-7456.

53 Chee KG, Lara PN, Longmate J, Twardowski P, Quinn DI, Chatta $\mathrm{G}$ et al. The AKT inhibitor perifosine in biochemically recurrent, hormone-sensitive prostate cancer (HSPC): a phase II California Cancer Consortium Trial. I Clin Oncol 2005; 23S, Abstract 4563.

54 Posadas EM, Gulley J, Arlen PM, Trout A, Parnes HL, Wright J et al. A phase II study of perifosine in androgen independent prostate cancer. Cancer Biol Ther 2005; 4: 1133-1137.

55 Dasmahapatra GP, Didolkar P, Alley MC, Ghosh S, Sausville EA, Roy KK. In vitro combination treatment with perifosine and $\mathrm{UCN}-01$ demonstrates synergism against prostate (PC-3) and lung (A549) epithelial adenocarcinoma cell lines. Clin Cancer Res 2004; 10: 5242-5252.

56 Sarkar FH, Adsule S, Padhye S, Kulkarni S, Li Y. The role of genistein and synthetic derivatives of isoflavone in cancer prevention and therapy. Mini Rev Med Chem 2006; 6: 401-407.

57 Sarkar FH, Li Y. Mechanisms of cancer chemoprevention by soy isoflavone genistein. Cancer Metastasis Rev 2002; 21: 265-280.

58 Bemis DL, Capodice JL, Desai M, Buttyan R, Katz AE. A concentrated aglycone isoflavone preparation (GCP) that demonstrates potent anti-prostate cancer activity in vitro and in vivo. Clin Cancer Res 2004; 10: 5282-5292.

59 Bektic J, Guggenberger R, Eder IE, Pelzer AE, Berger AP, Bartsch $\mathrm{G}$ et al. Molecular effects of the isoflavonoid genistein in prostate cancer. Clin Prostate Cancer 2005; 4: 124-129.

60 Skogseth H, Follestad T, Larsson E, Halgunset J. Transcription levels of invasion-related genes in prostate cancer cells are modified by inhibitors of tyrosine kinase. APMIS 2006; 114: 364-371.

61 Chen HL, Holland WS, Lara PN, Gandara D, White RD, Gumerlock P. Preclinical study of genistein combined polysaccharide (GCP) and docetaxel (Doc) treatment of prostate cancer (CaP) cells. I Clin Oncol 2005; 23S, Abstract 4711.

62 Holland WS, Shih D, Harse R, Vijaykumar S, Hackman R, Gandara D et al. Inhibition of the AKT pathway with genistein combined polysaccharide (GCP) plus external beam radiation therapy (EBRT) in prostate cancer (CaP) xenograft. J Clin Oncol 2005; 23S, Abstract 3135.

$63 \mathrm{Li}$ Y, Sarkar FH. Inhibition of nuclear factor kappaB activation in PC 3 cells by genistein is mediated via Akt signaling pathway. Clin Cancer Res 2002; 8: 2369-2377.

64 Tepper CG, Vinall RL, Wee CB, Xue L, Shi XB, Burich R et al. GCP-mediated growth inhibition and apoptosis of prostate cancer cells via androgen receptor-dependent and -independent mechanisms. Prostate 2007; 67: 521-535.

65 Rannikko A, Petas A, Rannikko S, Adlercreutz H. Plasma and prostate phytoestrogen concentrations in prostate cancer patients after oral phytoestogen supplementation. Prostate 2006; 66: $82-87$.

66 Poisson BA, Takimoto C, Shapiro A, Gallot L, Nabhan C, Lieberman $\mathrm{R}$ et al. Pharmacokinetic analysis of the putative prostate cancer chemopreventive agent, genistein. Proc Am Soc Clin Oncol 2001; 20, Abstract 334

67 deVere White RW, Hackman RM, Soares SE, Beckett LA, Li Y, Sun B. Effects of a genistein-rich extract on PSA levels in men with a history of prostate cancer. Urology 2004; 63: 259-263.

68 Chuang SE, Yeh PY, Lu YS, Lai GM, Liao CM, Gao M et al. Basal levels and patterns of anticancer drug-induced activation of nuclear factor-kappaB (NF-kappaB), and its attenuation by tamoxifen, dexamethasone, and curcumin in carcinoma cells. Biochem Pharmacol 2002; 63: 1709-1716. 
69 Brognard J, Clark AS, Ni Y, Dennis PA. Akt/protein kinase B is constitutively active in non-small cell lung cancer cells and promotes cellular survival and resistance to chemotherapy and radiation. Cancer Res 2001; 61: 3986-3997.

70 Kennedy S. Proteomic profiling from human samples: the body fluid alternative. Toxicol Lett 2001; 120: 379-384.

71 Rabilloud T. Detecting proteins separated by 2-D gel electrophoresis. Anal Chem 2000; 72: 48A-55A.

72 Patel MI, Subbaramaiah K, Du B, Chang M, Yang P, Newman RA et al. Celecoxib inhibits prostate cancer growth: evidence of a cyclooxygenase-2-independent mechanism. Clin Cancer Res 2005; 11: 1999-2007.

73 Kulp SK, Yang YT, Hung CC, Chen KF, Lai JP, Tseng PH et al. 3-phosphoinositide-dependent protein kinase-1/Akt signaling represents a major cyclooxygenase-2-independent target for celecoxib in prostate cancer cells. Cancer Res 2004; 64: 1444-1451.

74 Sato S, Fujita N, Tsuruo T. Interference with PDK1-Akt survival signaling pathway by UCN-01 (7-hydroxystaurosporine). Oncogene 2002; 21: 1727-1738.

75 Feldman RI, Wu JM, Polokoff MA, Kochanny MJ, Dinter H, Zhu $\mathrm{D}$ et al. Novel small molecule inhibitors of 3-phosphoinositidedependent kinase-1. J Biol Chem 2005; 280: 19867-19874.

76 Breitenlechner CB, Wegge T, Berillon L, Graul K, Marzenell K, Friebe WG et al. Structure-based optimization of novel azepane derivatives as PKB inhibitors. J Med Chem 2004; 47: 1375-1390.

77 Chijiwa T, Mishima A, Hagiwara M, Sano M, Hayashi K, Inoue T et al. Inhibition of forskolin-induced neurite outgrowth and protein phosphorylation by a newly synthesized selective inhibitor of cyclic AMP-dependent protein kinase, N-[2-(p-bromocinnamylamino)ethyl]-5-isoquinolinesulfonamide (H-89), of PC12D pheochromocytoma cells. J Biol Chem 1990; 265: 5267-5272.

78 Reuveni H, Livnah N, Geiger T, Klein S, Ohne O, Cohen I et al. Toward a PKB inhibitor: modification of a selective PKA inhibitor by rational design. Biochemistry 2002; 41: 10304-10314.

$79 \mathrm{Hu}$ Y, Qiao L, Wang S, Rong SB, Meuillet EJ, Berggren M et al. 3-(Hydroxymethyl)-bearing phosphatidylinositol ether lipid analogues and carbonate surrogates block PI3-K, Akt, and cancer cell growth. J Med Chem 2000; 43: 3045-3051.

80 Castillo SS, Brognard J, Petukhov PA, Zhang C, Tsurutani J, Granville CA et al. Preferential inhibition of Akt and killing of Akt-dependent cancer cells by rationally designed phosphatidylinositol ether lipid analogues. Cancer Res 2004; 64: 2782-2792.

81 Gills JJ, Holbeck S, Hollingshead M, Hewitt SM, Kozikowski AP, Dennis PA. Spectrum of activity and molecular correlates of response to phosphatidylinositol ether lipid analogues, novel lipid-based inhibitors of Akt. Mol Cancer Ther 2006; 5: 713-722.

82 Meuillet EJ, Ihle N, Baker AF, Gard JM, Stamper C, Williams R et al. In vivo molecular pharmacology and antitumor activity of the targeted Akt inhibitor PX-316. Oncol Res 2004; 14: 513-527.

83 Luo Y, Smith RA, Guan R, Liu X, Klinghofer V, Shen J et al. Pseudosubstrate peptides inhibit Akt and induce cell growth inhibition. Biochemistry 2004; 43: 1254-1263.

84 Hiromura M, Okada F, Obata T, Auguin D, Shibata T, Roumestand $\mathrm{C}$ et al. Inhibition of Akt kinase activity by a peptide spanning the betaA strand of the proto-oncogene TCL1. J Biol Chem 2004; 279: 53407-53418.

85 Barnett SF, Defeo-Jones D, Fu S, Hancock PJ, Haskell KM, Jones $\mathrm{RE}$ et al. Identification and characterization of pleckstrinhomology-domain-dependent and isoenzyme-specific Akt inhibitors. Biochem J 2005; 385: 399-408.

86 Lindsley CW, Zhao Z, Leister WH, Robinson RG, Barnett SF, Defeo-Jones $\mathrm{D}$ et al. Allosteric Akt (PKB) inhibitors: discovery and SAR of isozyme selective inhibitors. Bioorg Med Chem Lett 2005; 15: 761-764.

87 Shin I, Edl J, Biswas S, Lin PC, Mernaugh R, Arteaga CL. Proapoptotic activity of cell-permeable anti-Akt single-chain antibodies. Cancer Res 2005; 65: 2815-2824.

88 Hoffman K, Holmes FA, Fraschini G, Esparza L, Frye D, Raber $\mathrm{MN}$ et al. Phase I-II study: triciribine (tricyclic nucleoside phosphate) for metastatic breast cancer. Cancer Chemother Pharmacol 1996; 37: 254-258.

89 Yang L, Dan HC, Sun M, Liu Q, Sun XM, Feldman RI et al. Akt/ protein kinase B signaling inhibitor-2, a selective small molecule inhibitor of Akt signaling with antitumor activity in cancer cells overexpressing Akt. Cancer Res 2004; 64: 4394-4399.

90 Feun LG, Blessing JA, Barrett RJ, Hanjani P. A phase II trial of tricyclic nucleoside phosphate in patients with advanced squamous cell carcinoma of the cervix. A Gynecologic Oncology Group Study. Am J Clin Oncol 1993; 16: 506-508.

91 Mandal M, Kim S, Younes MN, Jasser SA, El-Naggar AK, Mills GB et al. The Akt inhibitor KP372-1 suppresses Akt activity and cell proliferation and induces apoptosis in thyroid cancer cells. Br J Cancer 2005; 92: 1899-1905.

92 Thimmaiah KN, Easton JB, Germain GS, Morton CL, Kamath S, Buolamwini JK et al. Identification of N10-substituted phenoxazines as potent and specific inhibitors of Akt signaling. J Biol Chem 2005; 280: 31924-31935. 


\title{
Prostate cancer and markers of bone metabolism: diagnostic, prognostic, and therapeutic implications
}

\author{
Eric C. Nelson · Christopher P. Evans • \\ Chong-Xian Pan · Primo N. Lara Jr
}

Received: 1 February 2007 / Accepted: 15 May 2007 / Published online: 12 June 2007

(C) Springer-Verlag 2007

\begin{abstract}
Knowledge of bone metastases complicating advanced prostate cancer $(\mathrm{CaP})$ is increasingly relevant in patient selection for novel therapies. Current nuclear bone scintigraphy imaging has limited specificity for prostate metastases. As serum bone markers do correlate with bony lesions, they may play multiple roles in patients with advanced CaP. Currently, these markers play a role in prognostic nomograms for $\mathrm{CaP}$. Recent studies suggest an expanding role for bone markers in the diagnosis and selection of patients for novel therapies. In the future, therapeutic roles for some of these marker pathways will emerge, eventually allowing greater individualization of patient care.
\end{abstract}

Keywords Androgen-independent prostate cancer . Bone markers · Bone metastases · Osteoprotegerin . Prostate cancer

E. C. Nelson · C. P. Evans

Department of Urology, University of California,

Davis Medical Center, 4860 Y St, Suite 3500,

Sacramento, CA 95817, USA

e-mail: enelson06m@gmail.com

C. P. Evans

e-mail: christopher.evans@ucdmc.ucdavis.edu

C.-X. Pan · P. N. Lara Jr $(\bowtie)$

Department of Internal Medicine,

Division of Hematology and Oncology,

School of Medicine, University of California,

Davis, 4501 X Street, Sacramento, CA 95817, USA

e-mail: primo.lara@ucdmc.ucdavis.edu

C.-X. Pan

e-mail: chong-xian.pan@ucdmc.ucdavis.edu

\section{Introduction}

In advanced prostate cancer $(\mathrm{CaP})$, metastatic deposits in bone are common and are the most frequent source of pain and morbidity [1]. "Skeletal related events" or SREs include vertebral compression fractures, complete vertebral collapse, spinal cord or spinal nerve entrapment, pathologic fractures, bone pain, and significant serum calcium abnormalities. These may be directly related to metastatic deposits in the bone, or be secondary to medical or surgical castration, which forms the foundation of current treatment strategies for metastatic $\mathrm{CaP}$ [2]. Osteoporosis due to castration is the more common cause, with only $7-16 \%$ of fractures being caused directly by metastatic lesions [3]. In addition, an association exists between the diagnosis of $\mathrm{CaP}$ and baseline osteopenia and osteoporosis prior to treatment or the development of metastatic disease [4]. Overall, yearly incidence of SREs is about $12 \%$ in patients with metastatic androgen-independent $\mathrm{CaP}$ [5].

\section{Bone metabolism overview}

Normal bone metabolism is distinguished by two opposing activities, which are coupled in both space and time and subject to tight control. The formation of new bone by osteoblasts and the resorption of old bone by osteoclasts are both constitutively active and the balance of these activities ultimately determines bone mass.

Bony metastatic lesions in $\mathrm{CaP}$ are classically thought of as osteoblastic or sclerotic lesions caused by a relative increase in bone formation. Though this is true for the majority of lesions, recent studies have indicated a therapeutic role for osteoclast inhibition in the prevention of SREs. Specifically, zoledronic acid has been shown to be the only 
effective bisphosphonate for decreasing SREs in patients with advanced $\mathrm{CaP}$ [6]. This activity by an osteoclast inhibitor in what are typically osteoblastic lesions emphasizes the close coupling of the action of these two cells.

Current diagnostic strategies for metastatic $\mathrm{CaP}$ in bone rely on nuclear bone scintigraphy scans. Unfortunately, these are expensive, require special equipment, are relatively cumbersome and expose the patient to radiation. As these scans detect increased bone formation, they are highly sensitive for detecting metastatic $\mathrm{CaP}$ lesions. However, they lack specificity and do not accurately measure treatment response as increased bone formation may correlate with healing areas of lytic lesions [7]. The need for more specificity in diagnostic algorithms for $\mathrm{CaP}$ bone metastases suggests the possibility of using bone markers, either alone, or in combination with imaging studies to increase the accuracy of diagnosis.

Bone markers are typically biologically inactive peptide fragments or small proteins cleaved from larger proteins and released into the blood during the formation or resorption of bone. A list of bone markers used in CaP appears in Table 1. Only those with most clinical relevance will be discussed here.

Table 1 Selected markers of bone metabolism relevant to $\mathrm{CaP}$

\begin{tabular}{lll}
\hline & Markers & Measured in \\
\hline Markers of formation & tALP & Serum \\
& bALP & Serum \\
& PINP/PIIINP & Serum \\
& OC & Serum \\
& PICP & Serum \\
Markers of resorption & BSP & Serum \\
& ICTP & Serum \\
& CTx & Serum \\
& NTx & Serum \\
& TRAP & Serum \\
& Deoxypyridinoline & Serum/Urine \\
& Pyridinoline & Serum/Urine \\
& Hydroxyproline & Urine \\
& N-terminal telopeptide & Serum/Urine \\
& of type I collagen & \\
& Calcium:Creatinine ratio & Urine \\
& OPG & Serum \\
Markers of & RANKL & Serum \\
osteoclastogenesis & OP &
\end{tabular}

$\overline{b A L P}$ Bone alkaline phosphatase; $B S P$ bone sialoprotein; $C a P$ prostate cancer; $C T x$ carboxy-terminal telopeptide; ICTP pyridinoline crosslinked carboxy-terminal telopeptide; NTx amino-terminal telopeptide; $O C$ osteocalcin; $O P G$ osteoprotegerin; PICP procollagen I carboxyterminal propeptide; PIIINP procollagen III amino-terminal propeptide; $P I N P$ procollagen I amino-terminal propeptide; $R A N K L$ receptor activator of $\mathrm{NF} \kappa \mathrm{B}$ ligand; $t A L P$ total alkaline phosphatase; TRAP tartrate resistant acid phosphatase

\section{Formation markers}

Among the markers of bone formation are alkaline phosphatase, procollagen peptide fragments (which are cleaved at the time of bone collagen formation), and osteocalcin (OC). Total alkaline phosphatase (tALP) has also traditionally been used as a marker for bone formation because of its wide availability as part of the comprehensive metabolic panel. However, it lacks true specificity for bone due to its presence in biliary, hepatic, and intestinal tissues. The bone isoenzyme form of alkaline phosphatase (bALP), a tetrameric protein located in the plasma membrane of osteoblasts, has been used to overcome this deficiency. The procollagen peptide fragments, on the other hand, are byproducts of the extracellular cleavage of pro-collagen during bone formation and are specific for bone formation. These fragments are released into the circulation and are detected clinically using antibodies directed against the amino- (PINP) and carboxy- (PICP) terminal ends of procollagen I, or against the amino-terminal end of procollagen III (PIIINP) [8]. Finally, OC is a vitamin K-dependent, non-collagenous low molecular weight protein produced and released by osteoblasts. OC, also known as Gla protein, is widely deposited in the bony matrix and is the most abundant organic component of bone after collagen. Its presence in human sera is believed to be an index of osteoblastic activity and has been proposed as a useful marker for treatment response in metastatic $\mathrm{CaP}$ [9].

Resorption markers

Among the markers for bone resorption are the pyridinium compounds pyridinoline and deoxypyridinoline, both of which are found in Type I collagen and are amino acid derivatives. It has long been known that the tensile strength of bone is largely due to cross-linking of these derivatives in Type I collagen [10]. The deoxypyridinoline crosslink is felt to be specific to bone since it is only found in Type I collagen. On the other hand, pyridinoline is also present in Type II collagen, a component of articular cartilage. During bone resorption, these pyridinium cross-links are released into the circulation. Once released by the resorptive process, the pyridinium cross-links are not metabolized further; therefore, they represent degradative end products of mature collagen [11]. Another resorption marker is the collagen degradative product telopeptide, on which pyridinium cross-links are attached [12]. These include the amino- or carboxy-terminal telopeptide assay called N-telopeptide (NTx) and C-telopeptide (CTx) fragments, respectively. The commercial assay employs an antibody against the alpha-2 chain of Type I bone collagen fibrils. A related marker of a slightly larger telopeptide of the carboxy terminal is abbreviated ICTP [13]. Though some of these 
markers may also be measured in urine, serum collection allows simultaneous measurement of other markers, is convenient in the setting of clinical trials, and may be more reproducible.

\section{Osteoclastogenesis markers}

A new class of bone markers may more closely reflect the biochemistry of the metastatic site by giving insights into cellular signaling. Osteoprotegerin (OPG), receptor activator of $\mathrm{NF} \kappa \mathrm{B}$ (RANK), and receptor activator of $\mathrm{NF} \kappa \mathrm{B}$ ligand (RANKL) are thought to belong to an important cytokine system controlling the process of osteoclastogenesis. Preclinical data confirms the importance of the relative concentration of these cellular signaling molecules in controlling the balance of bone formation and breakdown [14]. These markers may not only serve as a surrogate for osteoclastic activity but may prove to be important in future therapeutic interventions.

\section{Bone markers: potential diagnostic applications}

Because nearly all the bone markers discussed above show strong correlation with bone scan results in multiple studies, the use of bone markers as diagnostic instruments has been proposed. Various studies have shown promising results for ICTP [15], PINP [16, 17], CTx [17] and OPG [18]. Most studied markers demonstrate a wide range of results, which negatively impacts sensitivity and specificity. In addition, other conditions such as arthritis or bone healing secondary to trauma may further decrease specificity. Therefore, though mean bone marker concentration is of diagnostic significance for a population, individual patient counseling is difficult.

As mentioned previously, bone scintigraphy scans have high sensitivity but low specificity. Any effort to increase the specificity of diagnostic testing requires a highly specific "gold standard" for comparison. In this setting, only biopsy of each metastatic deposit would qualify as such a gold standard and this is obviously not feasible. Increase in lesion size on imaging of untreated patients may provide a surrogate marker but is also rather unhelpful, as most patients will be treated. Lesion shrinkage may not be seen on imaging with treatment as bone scans cannot discriminate between bone formation activity of metastatic disease and the healing process following response to treatment.

The strong rationale supporting bone markers as a diagnostic modality encourages efforts to find a surrogate marker verifying adequate specificity. One strategy is to acquire an ability to predict future metastatic deposits on imaging. If bone markers are able to do this, it may provide the needed proof of concept. At least one small study has demonstrated that increases in bone markers precede evi- dence of bony metastatic lesions on bone scan by about 3 months [19]. This study measured urinary pyridinolines normalized by creatinine and should be repeated using other markers to confirm the concept. In the future, algorithms using bone scintigraphy in combination with prostate specific antigen (PSA) and various bone markers will maximize sensitivity and specificity in the diagnosis of $\mathrm{CaP}$.

\section{Bone markers: prognostic implications}

Compared to proving diagnostic specificity, it is easier to demonstrate the ability of bone markers to stratify patients into prognostic categories. The use of bone markers in prognostic nomograms is well known. At least since 1992, tALP has been included in many nomograms predicting outcomes for different patient populations with $\mathrm{CaP}[20$ 23]. As discussed above, other bone markers demonstrate the ability to predict future bone metastases. This suggests they might have a prognostic role in predicting overall survival.

Correlative studies confirm the prognostic capabilities of some bone metabolism markers. Brown et al. [24] retrospectively examined bALP and NTx in large patient cohorts from phase III studies examining zoledronic acid in metastatic $\mathrm{CaP}$ and other neoplasms [25, 26]. In patients in the placebo arms of the trials, both NTx and bALP were statistically significant predictors of outcome, though NTx was superior [24]. Because of the results of the prospective phase III trial, zoledronic acid treatment is likely to be given to many patients with metastatic hormone refractory $\mathrm{CaP}$ [25]. As zoledronic acid significantly affects NTx levels, a second study by Cook et al. [27] examined all $\mathrm{CaP}$ patients using only baseline NTx and bALP levels. They found both markers were significantly associated with overall survival and progression-free survival, but only bALP was independently associated with overall survival on multivariate analysis. Dividing patients into quartiles based on bALP correlated strongly with overall survival and thus may be a useful prognostic tool for clinicians and patients.

Our group prospectively evaluated the prognostic and predictive significance of selected markers of bone metabolism in the context of a randomized phase II clinical trial of a matrix metalloproteinase inhibitor in hormone refractory $\mathrm{CaP}$ [28]. Markers of bone formation (OC, PINP and PIIINP) and resorption (NTx, pyridinoline and deoxypyridinoline) in serum were measured using commercial enzyme immunoassays. Marker values were dichotomized at the median and correlated with overall survival and progression-free survival by log-rank testing. Of eighty patients enrolled, 69 had evaluable baseline serum specimens. 
We found that lower levels of tALP, NTx, deoxypyridinoline, OC, PINP, and PIIINP were all significant predictors of improved median and progression-free survival. In our study population, the significant prognostic value of these markers was not affected by bisphosphonate treatment. On multivariate analysis, log PINP and PIIINP remained significant as part of a model including hemoglobin and log PSA [29].

These retrospective and prospective clinical results should be prospectively validated in the phase III setting. Toward that end, we have initiated a molecular correlative study of the prognostic and possible predictive value of bone markers in patients with bone-metastatic hormone refractory $\mathrm{CaP}$ in conjunction with Southwest Oncology Group trial S0421. This phase III, placebo-controlled trial of docetaxel/prednisone with or without Atrasentan will randomize 706 patients with hormone refractory $\mathrm{CaP}$ and bone metastases, and provides an ideal setting to study bone markers. Earlier trials indicate Atrasentan's modest therapeutic effect is most significant in patients with bone metastases [30]. Serial measurements of bone markers will hopefully allow creation of validated prognostic nomograms. In addition, discovery of bone marker parameters predicting a beneficial response to Atrasentan will in the future allow appropriate patient selection for therapy.

In addition to predicting survival, bone markers may be able to predict response to treatment with androgen ablation. As discussed below, studies show a clear correlation of bone markers with treatment response on imaging and clinical improvement. With further refinement, new markers more closely reflecting actual bone biochemistry may predict not only overall survival for patient populations, but may allow for individualized treatment.

\section{Bone markers: disease activity monitoring}

As early as 1992, studies have examined the ability of bone markers to monitor the metastatic $\mathrm{CaP}$ response to androgen deprivation [9]. Clear correlation of bone marker changes on serial measurements with clinical response, whether based on imaging or PSA, has been conclusively demonstrated. Urinary pyridinolines [19], PICP [31], ICTP [15] and PINP [32] have all shown significant correlations. In addition, Koizumi et al suggest that the ratios of markers of bone formation may be helpful in following response to treatment [32].

In the future, bone markers may play a role in monitoring disease in patients with or without clear metastatic disease on bone scan. Though further studies are needed before this occurs, a strong rationale exists for using bone markers in this setting. As mentioned above, elevations in bone markers may precede evidence of bony metastatic lesions by up to three months. Thus, the useful of these markers for monitoring disease is suggested, even in patients with no corroborating imaging.

\section{Bone markers: therapeutic}

The novel bone marker OPG, in contrast to most other markers, is a biologically active member of the tumor necrosis factor (TNF) superfamily [33]. As a decoy receptor for RANKL, it inhibits downstream signaling activating osteoclasts [14]. It may prevent apoptosis by inhibiting TNF related apoptosis inducing ligand or TRAIL [34]. Preclinical studies also suggest a role for OPG in promoting angiogenesis [35]. The variety of effects apparently related to this cytokine system suggest it not only provides a marker of diagnosis and prognosis, but may suggest therapeutic interventions $[14,34,35]$.

A fully human monoclonal antibody against RANKL has recently entered clinical trials. Denosumab may be considered an OPG analogue in that it binds and inactivates RANKL. A phase III randomized, double blind, multicenter comparison of denosumab with the current reference standard, zoledronic acid, in patients with metastatic $\mathrm{CaP}$ began in April 2006. Results are eagerly anticipated.

The superiority of OPG as a marker, discussed below, may be due to the fact that it represents not only a byproduct of bone metabolism, but also an active participant in the microenvironment affecting metastatic growth and related bone turnover.

\section{Bone marker comparisons}

Few head to head comparisons of the various bone markers have been performed and those studies listed in Table 2 may sometimes yield contradictory results. This may be due to different patient populations and the fact that different bone markers measure different stages of bone metabolism and are affected differently by androgen deprivation $[13,16]$. Nevertheless, some conclusions can be drawn. tALP and bALP have been the most studied and consistently demonstrate equivalent, and sometimes superior prognostic value compared to other markers [13, 27]. Of the other markers of bone formation, PINP may be preferable to use as a marker $[16,17,29]$. OC is clearly inferior to other markers $[5,13,18]$.

Deciding which of the markers of bone resorption is most accurate is more difficult. One study comparing multiple bone markers suggests that OPG is most helpful for prognostic use [18]. As a marker of osteoclastogenesis, it may serve as a marker for osteoclast action while giving additional prognostic information based on tumor biochemistry. However, OPG is not, strictly speaking, a marker of bone resorption. Future studies should prospectively assess OPG in comparison to CTx, NTx, ICTP, and the pyridinolines. 


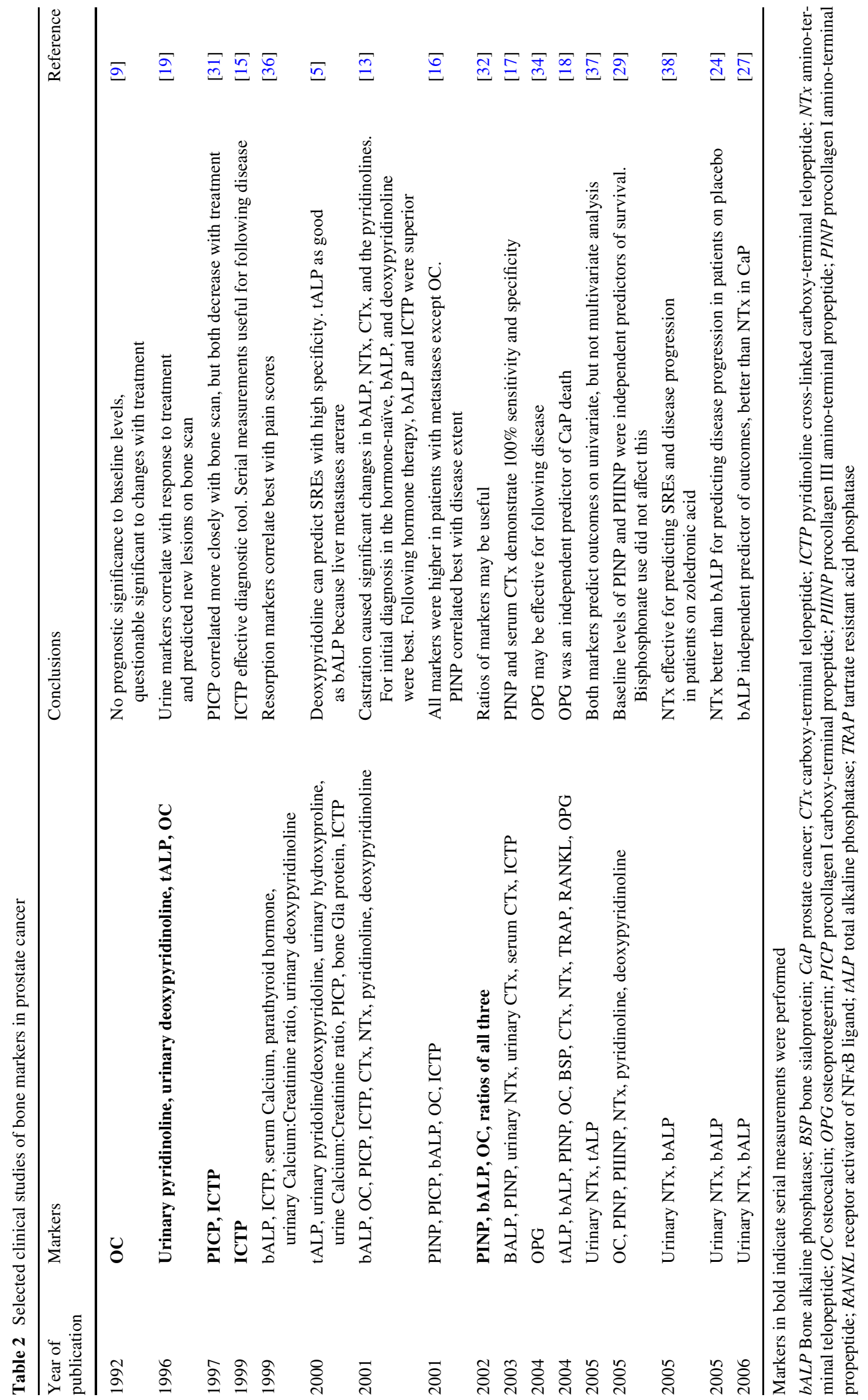




\section{Conclusions}

Markers of bone metabolism play a role in current prognostic nomograms for $\mathrm{CaP}$. In the future, their role will increase, especially in the areas of earlier diagnosis of bony metastatic disease and the monitoring of therapeutic interventions. Bone markers will extend the specificity of current diagnostic imaging techniques and panels of bone markers may reach sufficient accuracy to be used alone. Serial measurements of bone markers will allow greater insight into the action of novel therapies currently under development for CaP. Finally, bone markers of metabolic activity, such as OPG, will suggest future strategies that will allow individualization of oncologic therapy.

Acknowledgments PNL is supported in part by RO1-CA120469, Veterans' Administration of Northern California, and NIH NO1 CM17101.

\section{References}

1. Michaelson MD, Smith MR (2005) Bisphosphonates for treatment and prevention of bone metastases. J Clin Oncol 23(32):82198224

2. Smith MR (2006) Markers of bone metabolism in prostate cancer. Cancer Treat Rev 1 (32 Suppl):23-26

3. Shahinian VB, Kuo YF, Freeman JL, Goodwin JS (2005) Risk of fracture after androgen deprivation for prostate cancer. N Engl $\mathrm{J}$ Med 352(2):154-164

4. Hussain SA, Weston R, Stephenson RN, George E, Parr NJ (2003) Immediate dual energy X-ray absorptiometry reveals a high incidence of osteoporosis in patients with advanced prostate cancer before hormonal manipulation. BJU Int 92(7):690-694

5. Berruti A, Dogliotti L, Bitossi R, Fasolis G, Gorzegno G, Bellina $\mathrm{M}$ et al (2000) Incidence of skeletal complications in patients with bone metastatic prostate cancer and hormone refractory disease: predictive role of bone resorption and formation markers evaluated at baseline. J Urol 164(4):1248-1253

6. Saad F, Gleason DM, Murray R, Tchekmedyian S, Venner P, Lacombe L et al (2004) Long-term efficacy of zoledronic acid for the prevention of skeletal complications in patients with metastatic hormone-refractory prostate cancer. J Natl Cancer Inst 96(11):879-882

7. Fontana A, Delmas PD (2000) Markers of bone turnover in bone metastases. Cancer 88(12 Suppl):2952-2960

8. Suvanto-Luukkonen E, Risteli L, Sundstrom H, Penttinen J, Kauppila A, Risteli J (1997) Comparison of three serum assays for bone collagen formation during postmenopausal estrogen-progestin therapy. Clin Chim Acta 266(2):105-116

9. Arai Y, Takeuchi H, Oishi K, Yoshida O (1992) Osteocalcin: is it a useful marker of bone metastasis and response to treatment in advanced prostate cancer? Prostate 20(3):169-177

10. Hanson DA, Eyre DR (1996) Molecular site specificity of pyridinoline and pyrrole cross-links in type I collagen of human bone. $\mathrm{J}$ Biol Chem 271(43):26508-26516

11. Demers LM, Costa L, Lipton A (2000) Biochemical markers and skeletal metastases. Cancer 88(12 Suppl):2919-2926

12. Hanson DA, Weis MA, Bollen AM, Maslan SL, Singer FR, Eyre DR (1992) A specific immunoassay for monitoring human bone resorption: quantitation of type I collagen cross-linked N-telopeptides in urine. J Bone Miner Res 7(11):1251-1258
13. Tamada T, Sone T, Tomomitsu T, Jo Y, Tanaka H, Fukunaga M (2001) Biochemical markers for the detection of bone metastasis in patients with prostate cancer: diagnostic efficacy and the effect of hormonal therapy. J Bone Miner Metab 19(1):45-51

14. Hofbauer LC, Neubauer A, Heufelder AE (2001) Receptor activator of nuclear factor-kappaB ligand and osteoprotegerin: potential implications for the pathogenesis and treatment of malignant bone diseases. Cancer 92(3):460-470

15. Koga H, Naito S, Koto S, Sakamoto N, Nakashima M, Yamasaki T et al (1999) Use of bone turnover marker, pyridinoline crosslinked carboxyterminal telopeptide of type I collagen (ICTP), in the assessment and monitoring of bone metastasis in prostate cancer. Prostate 39(1):1-7

16. Koizumi M, Yonese J, Fukui I, Ogata E (2001) The serum level of the amino-terminal propeptide of type I procollagen is a sensitive marker for prostate cancer metastasis to bone. BJU Int 87(4):348 351

17. de la Piedra C, Castro-Errecaborde NA, Traba ML, Mendez-Davila C, Garcia-Moreno C, Rodriguez de Acuna L et al (2003) Bone remodeling markers in the detection of bone metastases in prostate cancer. Clin Chim Acta 331(1-2):45-53

18. Jung K, Lein M, Stephan C, Von Hosslin K, Semjonow A, Sinha $\mathrm{P}$ et al (2004) Comparison of 10 serum bone turnover markers in prostate carcinoma patients with bone metastatic spread: diagnostic and prognostic implications. Int J Cancer 111(5):783-791

19. Takeuchi S, Arai K, Saitoh H, Yoshida K, Miura M (1996) Urinary pyridinoline and deoxypyridinoline as potential markers of bone metastasis in patients with prostate cancer. J Urol 156(5):16911695

20. Petrylak DP, Scher HI, Li Z, Myers CE, Geller NL (1992) Prognostic factors for survival of patients with bidimensionally measurable metastatic hormone-refractory prostatic cancer treated with single-agent chemotherapy. Cancer 70(12):2870-2878

21. Kelly WK, Scher HI, Mazumdar M, Vlamis V, Schwartz M, Fossa SD (1993) Prostate-specific antigen as a measure of disease outcome in metastatic hormone-refractory prostate cancer. J Clin Oncol 11(4):607-615

22. Smaletz O, Scher HI, Small EJ, Verbel DA, McMillan A, Regan K et al (2002) Nomogram for overall survival of patients with progressive metastatic prostate cancer after castration. J Clin Oncol 20(19):3972-3982

23. Halabi S, Small EJ, Kantoff PW, Kattan MW, Kaplan EB, Dawson NA et al (2003) Prognostic model for predicting survival in men with hormone-refractory metastatic prostate cancer. J Clin Oncol 21(7):1232-1237

24. Brown JE, Cook RJ, Major P, Lipton A, Saad F, Smith M et al (2005) Bone turnover markers as predictors of skeletal complications in prostate cancer, lung cancer, and other solid tumors. J Natl Cancer Inst 97(1):59-69

25. Saad F, Gleason DM, Murray R, Tchekmedyian S, Venner P, Lacombe L et al (2002) A randomized, placebo-controlled trial of zoledronic acid in patients with hormone-refractory metastatic prostate carcinoma. J Natl Cancer Inst 94(19):1458-1468

26. Rosen LS, Gordon D, Tchekmedyian S, Yanagihara R, Hirsh V, Krzakowski M et al (2003) Zoledronic acid versus placebo in the treatment of skeletal metastases in patients with lung cancer and other solid tumors: a phase III, double-blind, randomized trialthe Zoledronic acid lung cancer and other solid tumors study group. J Clin Oncol 21(16):3150-3157

27. Cook RJ, Coleman R, Brown J, Lipton A, Major P, Hei YJ et al (2006) Markers of bone metabolism and survival in men with hormone-refractory metastatic prostate cancer. Clin Cancer Res 12(11 Pt 1):3361-3367

28. Lara PN Jr, Stadler WM, Longmate J, Quinn DI, Wexler J, Van Loan $\mathrm{M}$ et al (2006) A randomized phase II trial of the matrix metalloproteinase inhibitor BMS-275291 in hormone-refractory 
prostate cancer patients with bone metastases. Clin Cancer Res 12(5):1556-1563

29. Lara PN, Longmate J, Stadler W, van Loan M, Wexler J, Quinn DI et al (2005) Markers of bone metabolism predict survival in hormone refractory prostate cancer (HRPC): results from a randomized California Cancer Consortium and Univ of Chicago trial. J Clin Oncol 23S(16S) Abst 4569

30. Nelson JB (2005) Endothelin receptor antagonists. World J Urol 23(1):19-27

31. Yoshida K, Sumi S, Arai K, Koga F, Umeda H, Hosoya Y et al (1997) Serum concentration of type I collagen metabolites as a quantitative marker of bone metastases in patients with prostate carcinoma. Cancer 80(9):1760-1767

32. Koizumi M, Yonese J, Fukui I, Ogata E (2002) Metabolic gaps in bone formation may be a novel marker to monitor the osseous metastasis of prostate cancer. J Urol 167(4):1863-1866

33. Holen I, Shipman CM (2006) Role of osteoprotegerin (OPG) in cancer. Clin Sci (Lond) 110(3):279-291

34. Eaton CL, Wells JM, Holen I, Croucher PI, Hamdy FC (2004) Serum osteoprotegerin (OPG) levels are associated with disease progression and response to androgen ablation in patients with prostate cancer. Prostate 59(3):304-310

35. Cross SS, Yang Z, Brown NJ, Balasubramanian SP, Evans CA, Woodward JK et al (2006) Osteoprotegerin (OPG) — a potential new role in the regulation of endothelial cell phenotype and tumour angiogenesis? Int J Cancer 118(8):1901-1908

36. Berruti A, Dogliotti L, Gorzegno G, Torta M, Tampellini M, Tucci $M$ et al (1999) Differential patterns of bone turnover in relation to bone pain and disease extent in bone in cancer patients with skeletal metastases. Clin Chem 45(8 Pt 1):1240-1247

37. Berruti A, Tucci M, Mosca A, Tarabuzzi R, Gorzegno G, Terrone C et al (2005) Predictive factors for skeletal complications in hormone-refractory prostate cancer patients with metastatic bone disease. Br J Cancer 93(6):633-638

38. Coleman RE, Major P, Lipton A, Brown JE, Lee KA, Smith M et al (2005) Predictive value of bone resorption and formation markers in cancer patients with bone metastases receiving the bisphosphonate zoledronic acid. J Clin Oncol 23(22):4925-4935 


\title{
Src family kinase oncogenic potential and pathways in prostate cancer as revealed by AZD0530
}

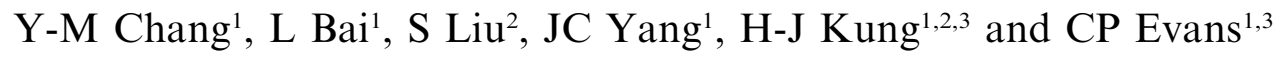 \\ ${ }^{1}$ Department of Urology, University of California at Davis, Sacramento, CA, USA; ${ }^{2}$ Department of Biological Chemistry and \\ Molecular Medicine, University of California at Davis, Sacramento, CA, USA and ${ }^{3}$ Cancer Center, University of California at Davis, \\ Sacramento, CA, USA
}

\begin{abstract}
Prostate cancer is the most frequently diagnosed cancer in American men. We have previously demonstrated that Src mediates androgen-independent proliferation in prostate cancer. We sought to investigate the Src-mediated oncogenic pathways and tumor biology using AZD0530, a novel Src family kinase/Abl dual-kinase inhibitor that is entering phase II clinical trials. We show that while both Src and Abl are expressed in all prostate cancer cell lines, Src but not Abl is activated in the prostate. Furthermore, Src activation is inhibited by AZD0530 in a rapid and dose-dependent manner. We show that Src mediates cell proliferation in DU145 and PC3 cells at the G1 phase of cell cycle. Src inhibition resulted in decreased binding of $\beta$-catenin to the promoters of G1 phase cell cycle regulators cyclin D1 and c-Myc. C-Myc may also be regulated at the protein level by extracellular signalregulated kinase $1 / 2$ and GSK3ß. Cell motility factors focal adhesion kinase, p130CAS and paxillin activation in DU145 and PC3 cells were also inhibited. Administration of AZD0530 in mice reduced orthotopic DU145 xenograft growth by $45 \%$. We have further delineated the Srcmediated oncogenic growth and migration pathways in prostate cancer and established mechanistic rationale for Src inhibition as novel therapy in the treatment of prostate cancer.
\end{abstract}

Oncogene advance online publication, 4 August 2008; doi:10.1038/onc.2008.250

Keywords: Src; FAK; prostate cancer; AZD0530; proliferation; migration

\section{Introduction}

Prostate cancer is the second leading cause of cancer death in men in the United States (Jemal et al., 2008). Though prostate cancer growth is hormonally regulated, antiandrogen therapy inevitably results in disease

Correspondence: Dr CP Evans, Department of Urology, University of California-Davis Medical Center, 4860 Y St Suite 3500, Sacramento, CA 95817, USA. E-mail: cpevans@ucdavis.edu and Dr H-J Kung E-mail: hkung@ucdavis.edu

Received 20 February 2008; revised 3 June 2008; accepted 10 June 2008 progression with uncontrolled growth and metastasis. An important mediator of this process is Src, a prototypical non-receptor tyrosine kinase (Lee et al., 2001; Desai et al., 2006).

The role of Src in human malignancies has not been fully appreciated in part because of the lack of frequent mutations in human cancers. Nevertheless, Src overexpression and activation are associated with numerous types of cancers (Biscardi et al., 2000; Yeatman, 2004; Zhu et al., 2007). Increasing evidence connects Src activity to prostate carcinogenesis. Src activity is required for androgen-independent activation of androgen receptor mediated by neuropeptide (Lee et al., 2001; Desai et al., 2006), epidermal growth factor (Guo et al., 2006) and interleukin-8 (Lee et al., 2004). Src and focal adhesion kinase (FAK), a Src substrate, are also involved in interleukin-8-induced migration of LNCaP. The application of pan-Src inhibitor 4-amino-5-(4chlorophenyl)-7-(t-butyl)pyrazolo[3,4-d]pyrimidine

(PP2) leads to significant suppression of androgenindependent growth and migration of LNCaP (Lee et al., 2001, 2004), as well as migration of PC3 and DU145 (Slack et al., 2001). Dasatinib, a Src family kinase $(\mathrm{SFK}) / \mathrm{Abl}$ dual-inhibitor, inhibits cell adhesion and migration of DU145 (Nam et al., 2005b). Besides growth (Lee et al., 2001, 2004; Kotha et al., 2006), survival (Unni et al., 2004; Nam et al., 2005a; Kotha et al., 2006) and metastasis (Lee et al., 2004; Nam et al., $2005 \mathrm{~b}$ ), Src is also implicated in angiogenesis (Gray et al., 2005) and neuroendocrine differentiation (Bang et al., 1994). Overall, these studies suggest that Src plays pleiotropic roles in prostate cancer, often in a cell context-dependent manner and that Src is a promising target for intervention.

Src is an integrator of divergent signals. In prostate cancer cells, Src is activated by growth factors, cytokines, chemokines and gastrin-releasing peptide. Src activation leads to the activation of FAK and Etk (endothelial/epithelial tyrosine kinase), kinases consistently activated or overexpressed in prostate cancer cells (Rovin et al., 2002; Guo et al., 2006). The pleiotropic effects of Src activity are almost certainly due to the multiple signal pathways engaged by Src and its accompanying kinases. Src is able to channel phosphorylation signals through Ras/Raf/extracellular signalregulated kinase (ERK) $1 / 2$ and in certain cells, 
phosphatidylinositol 3-kinase (PI3K)/AKT pathways. Somewhat selective to SFKs is their ability to activate signal and transducer of transcription (STAT) 3 and $\beta$-catenin, which leads to the activation of c-Myc (Bowman et al., 2001; Furstoss et al., 2002; Farkas et al., 2005) and consequently cyclin D1 (Steiner et al., 1998; Taj et al., 2001; Devi et al., 2002). Although STAT3 was shown to regulate cyclin D1 levels in prostate cancer, it remains unclear whether Src is an upstream regulator of STAT3 in prostate cancer cells, as some Src inhibitors do not diminish STAT3 activation and STAT3 can also be activated by Janus family kinases (Nam et al., 2005b; Kotha et al., 2006). The role of $\beta$-catenin activation in prostate carcinogenesis has been extensively documented (de la Taille et al., 2003; Chen et al., 2004; Cronauer et al., 2005; Verras and Sun, 2006). The importance of c-Myc activation in prostate cancer is underscored by recent reports that c-Myc overexpression in mice prostate epithelial tissues gives rise to malignant lesions and that a significant fraction of prostate cancers amplify region 8q24 encompassing c-Myc (Bromann et al., 2004; Dong, 2006). What is not well understood is the role of Src in the activation of $\beta$-catenin and c-Myc in prostate cancer. As for signaling pathways of migration and invasion in prostate cancer, it was shown that Src, through activated FAK, phosphorylates p130CAS (CRK-associated substrate) and upregulates matrix metalloproteinase (MMP)-9 (Hauck et al., 2002; Planas-Silva et al., 2006). In summary, Src transmits multiple signals including Ras/Raf/ERK1/2, $\mathrm{PI} 3 \mathrm{~K} / \mathrm{AKT}, \quad \beta$-catenin/c-Myc/cyclin D1 and FAK/ p130CAS/MMP-9 to induce growth, survival and migration in various types of cancer cells. Whether Src directly mediates cellular changes in prostate cancer through these signals remain unclear.

Recent interest in Src as a target for molecule-specific therapy has led to the development of small molecule inhibitors (Golas et al., 2003; Lombardo et al., 2004; Lee and Gautschi, 2006). Dasatinib inhibits PC3 growth (Lombardo et al., 2004; Park et al., 2008) and DU145 migration (Nam et al., 2005b). Although Dasatinib is shown to inhibit growth in vitro in prostate cancer and has been suggested to inhibit proliferation through Lyn not Src, its mechanism of action in inhibiting cell proliferation remains unclear. AZD0530 (AstraZeneca, Alderley Park, UK), a 5-, 7-substituted anilinoquinazoline, is another novel SFK/Abl dual-inhibitor (Figure 1a) (Hennequin et al., 2006; Lee and Gautschi, 2006). An oral compound with clinical therapeutic potential and low toxicity in phase I trials, it is highly specific with most kinases having in vitro kinase $\mathrm{IC}_{50}$ values greater than $10 \mu \mathrm{M}$. AZD0530 has antimigratory and modest antiproliferative effects in vitro in breast cancer (Hiscox et al., 2006). AZD0530 has not, however, been previously studied in prostate cancer nor have Srcmediated signal pathways inhibited by this compound been defined. This study provides the first characterizations of the molecular and biological effects of AZD0530 in prostate cancer.

We show in this study that Src inhibition leads to growth suppression and cell cycle arrest in prostate cancer, which is accompanied by inactivation of ERK1/
2 and AKT, activation of GSK3 $\beta$ and downregulation of $\beta$-catenin, c-Myc and cyclin D1. Focal adhesion kinase and p130CAS phosphorylation are also attenuated as Src activity is inhibited, leading to significantly reduced cell migration. We also extended the analysis of AZD0530 as an antitumor agent in vivo. Using DU145 as our orthotopic mouse model, we show that AZD0530 is an inhibitor of growth in vivo. These studies provide important information regarding this small molecule inhibitor and set the stage for NCI approved phase II trials, using AZD0530 in advanced prostate cancer.

\section{Results}

Src is expressed and activated in prostate cancer cell lines Autophosphorylation of Src at tyrosine 419 (Y419) is a surrogate marker of its activity (Bjelfman et al., 1990). Src is expressed in LNCaP, DU145 and PC3 cell lines and increased Src activity correlates with more aggressive phenotypes (Bang et al., 1994; Lee et al., 2001, 2004; Nam et al., 2005b; Kotha et al., 2006). Src activity and expression levels in CWR22Rv1, LAPC-4 and immortalized normal prostate epithelial cell lines such as RWPE-1 and PZ-HPV7, however, have not previously been characterized. We therefore sought to compare and contrast the relative Src activation and expression levels in these cell lines. As Abl is also an AZD0530 target, we sought to characterize Abl in prostate cell lines as well.

Two Src isoforms were detected (Figure 1b) and were confirmed as Src through transfection experiments with wild-type Src cDNA constructs (data not shown). Src is expressed and activated in prostate cell lines. Notably, DU145 and PC3, cell lines with higher rates of proliferation and increased cell motility demonstrate an increased activated-to-total Src ratio when compared to other phenotypically less aggressive cell lines. Accounting for $\alpha$-tubulin levels, immortalized cells express more Src but have lower activated-to-total Src ratio than cancer cells. Although $\mathrm{Abl}$ is expressed in all prostate cell lines, it is not activated.

Our analysis with other SFKs suggests that Src is the predominant species expressed in prostate cancer cell lines (data not shown). As AZD0530 inhibits all SFKs at comparable concentrations, our data apply to all members. For simplicity, we will describe our results in the context of Src.

\section{AZD0530 is a potent and rapid inhibitor of cellular Src} activation

We were interested in characterizing cellular $\mathrm{Src}$ inhibition by AZD0530. In DU145 and PC3, AZD0530 inhibited Src activation in a dose-dependent manner (Figure1c, left, right). Src inhibition by AZD0530 was also rapid, within $5 \mathrm{~min}$ of treatment (Figure 1c, center).

\section{AZD0530 inhibits growth and induces cell cycle arrest of prostate cancer}

Src is involved in prostate cancer cell proliferation. We were therefore interested in the effectiveness of 
<smiles></smiles>

Structure of AZD0530

\section{b}

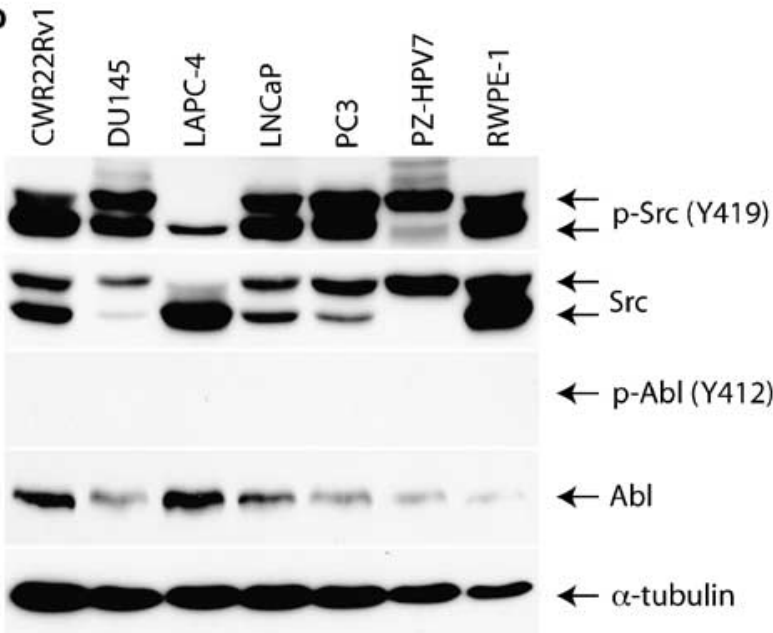

C

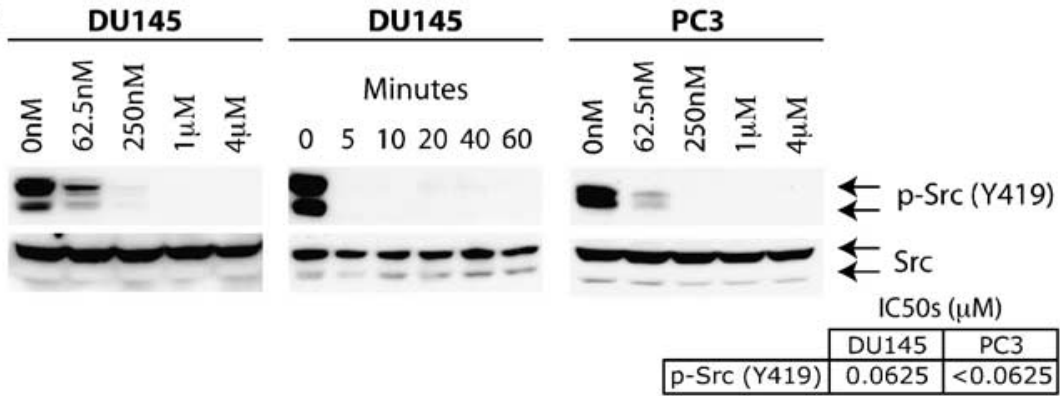

Figure 1 AZD0530 inhibits Src activation through inhibition of Y419 phosphorylation. (a) The chemical structure of AZD0530. (b) Commonly used cell lines were harvested and probed with Abl, p-Abl, phospho-Src Y419 and Src antibodies demonstrating relative increased ratio of activated-to-total Src in DU145 and PC3 cells. (c) Src autophosphorylation in DU145 and PC3 cells were inhibited in a dose-dependent manner by AZD0530 following 30-min treatment (left and right, respectively) or rapid manner by $1 \mu \mathrm{M}$ of AZD0530 (middle).

AZD0530 against mitogenesis. Single treatment with AZD0530 resulted in dose-dependent decrease of the number of cells in all cell lines (Figure 2a). LAPC-4, which has the smallest relative active-to-total Src ratio, is the most resistant against AZD0530 among prostate cancer cell lines. Immortalized nonmalignant cell lines PZ-HPV7 and RWPE-1 are also on average more resistant to Src inhibition than cancer cell lines. Figure $2 \mathrm{~b}$ shows the kinetics and the dose-responses of growth inhibition for DU145 and PC3 cells. These analyses substantiate the growth inhibitory effects of AZD0530 on prostate cancer cells.

Although AZD0530 decreased the number of prostate cancer cells over time, it was unclear whether this is secondary to apoptosis or decreased cell proliferation. Studies of other Src inhibitors on DU145 induced apoptosis and cell cycle arrest at the G0/G1 phase of the cell cycle (Nam et al., 2005a; Kotha et al., 2006). We thus sought to clarify the effects of AZD0530 using DU145 and PC3 as our models (Figure 2c). AZD0530 treatment of DU145 and PC3 respectively increased the proportion of $\mathrm{G} 0 / \mathrm{G} 1$ cells by 21 and $11 \%$ and concurrently decreased $\mathrm{S}$ cells by 22 and $10 \%$ in the cell cycle, respectively. The fraction of apoptotic cells (sub-G1) is very low in both treated and untreated DU145 and PC3 samples. Furthermore, there is no significant caspase 3 cleavage following AZD0530 treatment (Figure 2d). Thus, the decreased numbers of cells is not due to apoptosis but to cell cycle arrest at $\mathrm{G} 1 / \mathrm{S}$.

Inhibition of $c-M y c$ and cyclin D1 expression and downregulation of $\beta$-catenin by AZD0530

The effect of AZD0530 on G1/S transition prompted us to study its effect on c-Myc, an Src target gene 

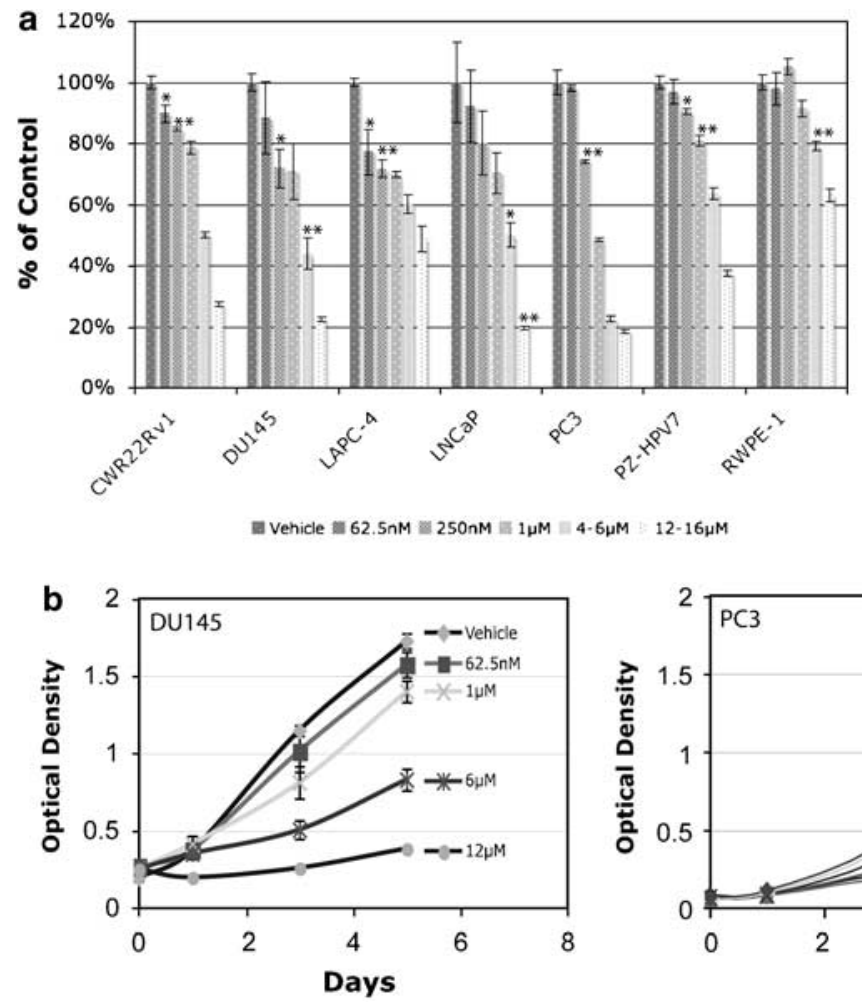

\begin{tabular}{|c|c|}
\cline { 2 - 2 } \multicolumn{1}{c|}{} & IC50s $(u \mathrm{M})$ \\
\hline CWR22Rv1 & 6 \\
\hline DU145 & $<6$ \\
\hline LAPC-4 & $<16$ \\
\hline LNCaP & 6 \\
\hline PC3 & $<1$ \\
\hline PZ-HPV7 & $<12-16$ \\
\hline RWPE-1 & $>16$ \\
\hline
\end{tabular}
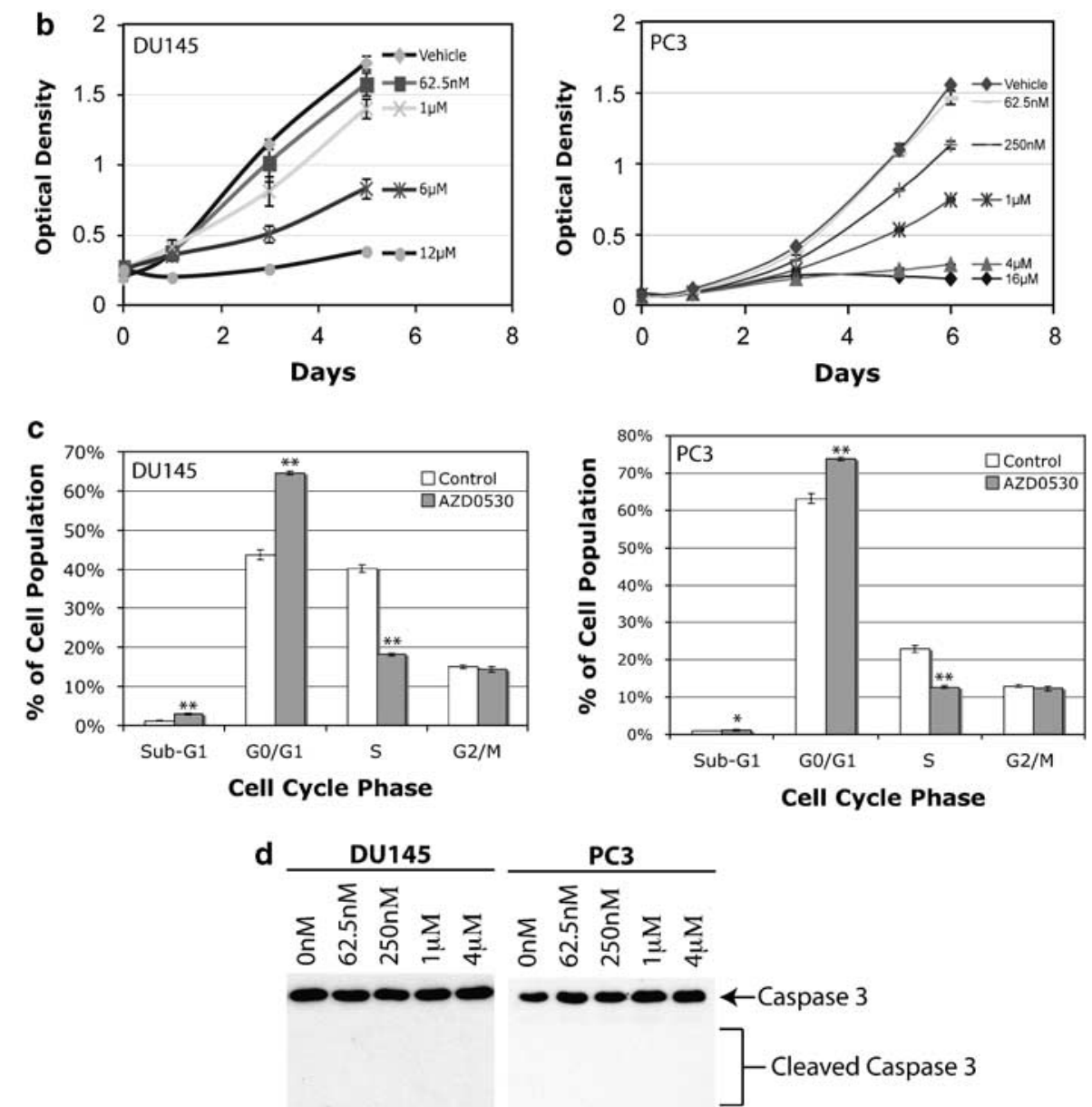

Figure 2 AZD0530 inhibits cell proliferation at G0/G1-S transition. (a) Single administration of AZD0530 inhibited cell proliferation in a dose-dependent manner in 3-[4,5-dimethylthiazol-2-yl]-2,5-diphenyl tetrazolium bromide assay showing immortalized cells on average being more resistant than malignant cell lines. (b) AZD0530 inhibited DU145 and PC3 proliferation in a dose-dependent manner over time. (c) AZD0530 induced G1/S cell cycle arrest but not apoptosis in DU145 and PC3 cells. (d) AZD0530 did not induce apoptosis in DU145 and PC 3 cells after 2 days, as shown by the lack of caspase 3 cleavage. Columns, mean; bars, standard error; $* P<0.05(n=3) ; * * P<0.01(n=3)$.

(Barone and Courtneidge, 1995) and cyclin D1, the rate limiting factor for cellular proliferation (Quelle et al., 1993; Albanese et al., 1995; Watanabe et al., 1996). Both were downregulated upon AZD0530 treatment (Figure 3a). Since c-Myc is more resistant to AZD0530 than Src, we sought to examine the kinetics of AZD0530 on c-Myc. Although both c-Myc and phospho-Src levels decrease after AZD0530 treatment, they both rebound over time, with relatively small changes in phospho-Src levels corresponding to larger changes seen in c-Myc. Cyclin D1 and c-Myc in DU145 cells are more sensitive to Src inhibition than PC3 cells. We further show corresponding reductions in transcripts (Figure 3b). 


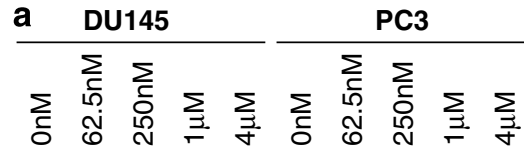

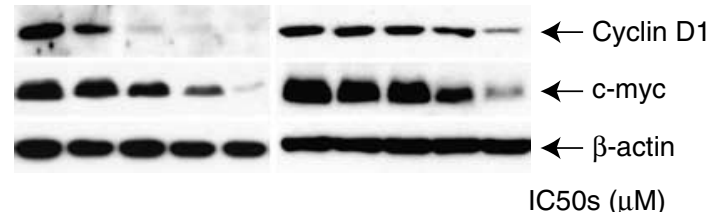

\begin{tabular}{|c|c|c|}
\cline { 2 - 3 } \multicolumn{1}{c|}{} & DU145 & PC3 \\
\hline Cyclin D1 & 0.25 & 4 \\
\hline c-Myc & 1 & $<4$ \\
\hline
\end{tabular}

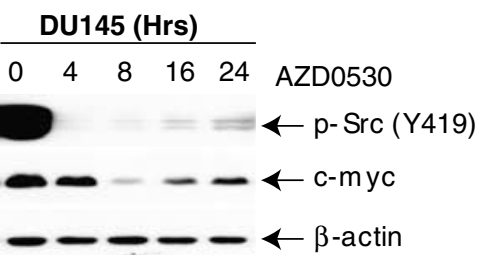

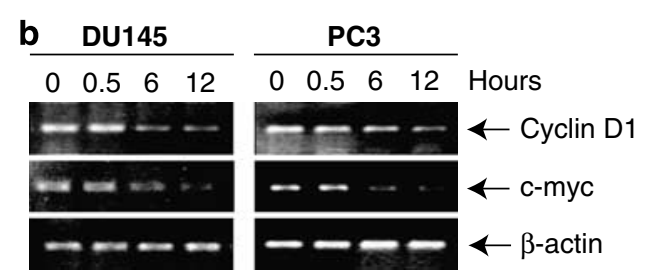

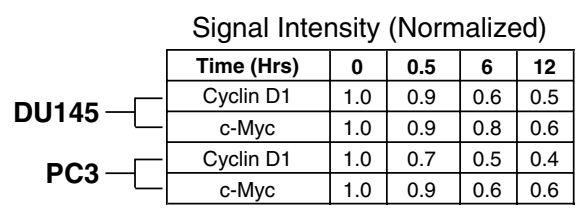

C

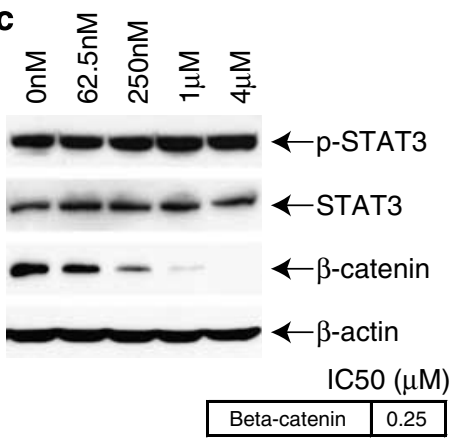

d
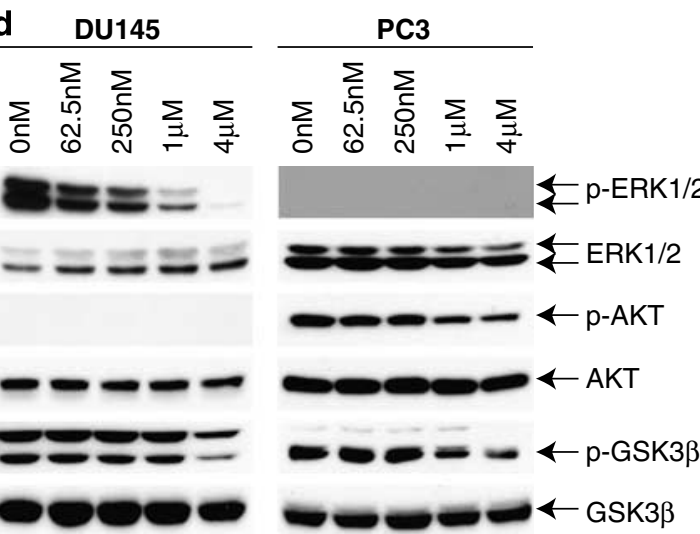

DU145 PC3 DU145 PC3

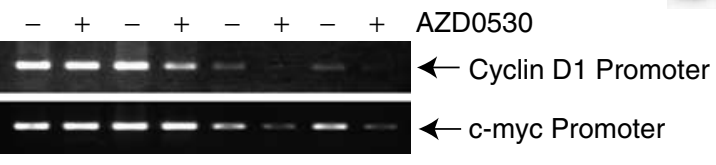

Input $\quad \beta$-catenin

\begin{tabular}{|l|c|c|}
\multicolumn{1}{c|}{} & \multicolumn{2}{c}{ IC50s $(\mu \mathrm{M})$} \\
\cline { 2 - 3 } \multicolumn{1}{c|}{} & DU145 & PC3 \\
\hline p-ERK & $<0.25$ & \\
\hline p-AKT & & 1 \\
\hline p-GSK3b & 4 & 4 \\
\hline
\end{tabular}

Figure 3 AZD0530 inhibits cell proliferation through $\beta$-catenin, ERK1/2 and GSK3 $\beta$-mediated cyclin D1 and c-myc regulation. (a) DU145 and PC3 cells treated with AZD0530 shows dose-dependent decreases in levels of cyclin D1 and c-Myc. Corresponding rebound of phospho-Src and c-Myc is seen over time. (b) Cyclin D1 and c-Myc transcript levels decreased following $4 \mu \mathrm{M}$ AZD0530 treatment. (c) AZD0530 treatment did not inhibit signal and transducer of transcription 3 activation after 30 min but downregulated $\beta$-catenin after $24 \mathrm{~h}$ (top). DU145 and PC3 treated with $4 \mu \mathrm{M}$ of AZD0530 for $12 \mathrm{~h}$ shows decreased binding of $\beta$-catenin to cyclin D1 and c-Myc promoter regions (bottom). (d) AZD0530 inhibited ERK1/2 and GSK3 $\beta$ phosphorylation in DU145 and AKT and GSK3 $\beta$ phosphorylation in PC3 after 30 min.

To study the upstream effectors that regulate c-Myc and cyclin D1 transcription, we noted that both STAT3 and $\beta$-catenin are Src targets and key transcriptional factors of c-Myc and cyclin D1 (Morin, 1999; Prathapam et al., 2006). We previously showed that Src enhances STAT3 tyrosine phosphorylation through Etk (Tsai et al., 2000). Other studies also showed that STAT3 mediates signals between Src and cyclin D1 in some prostate cancer cells (Gao et al., 2005; Kotha et al., 2006). Since PC3 does not express STAT3 (Yuan et al., 2005), we focused on DU145. In DU145, AZD0530 treatment does not affect STAT3 phosphory- lation, indicating its activation via a Src-independent pathway (Figure 3c, top).

We then turned our attention to $\beta$-catenin. $\beta$-catenin is a Src substrate (Roura et al., 1999) and its synthesis is activated by Src (Karni et al., 2005). It has also been shown to mediate both c-Myc and cyclin D1 transcription (Morin, 1999; Prathapam et al., 2006). The protein level of $\beta$-catenin is highly sensitive to AZD0530 treatment (Figure 3c, top). Furthermore, AZD0530 treatment results in decreased binding of $\beta$-catenin to both cyclin D1 and c-Myc promoters (Figure 3c, bottom). These data taken together suggest that Src 
mediates cell cycle progression by the induction of c-Myc and cyclin D1 transcription through increased $\beta$-catenin expression.

\section{Inhibition of ERK1/2 and GSK3 $\beta$ phosphorylation by $A Z D 0530$}

In addition to transcriptional regulation by $\beta$-catenin, c-Myc protein is regulated by ERK $1 / 2$ and AKT-GSK $3 \beta$. GSK3 $\beta$ phosphorylation of c-Myc at T58 leads to ubiquitin-mediated proteosomal degradation, whereas ERK1/2-mediated phosphorylation at S62 stabilizes c-Myc (Dominguez-Sola and Dalla-Favera, 2004; Sears, 2004). GSK $3 \beta$ in turn is inactivated by AKT and ERK1/ 2 (Cross et al., 1995; Cheng et al., 2005; Kim et al., 2007). Likewise, GSK3 $\beta$ negatively regulates the stability of $\beta$-catenin. We therefore wondered if AZD0530 inhibits ERK1/2 and AKT. ERK1/2 was inhibited by AZD0530 treatment, whereas AKT is constitutively inactive DU145 (Figure 3d). The lack of AKT activity is consistent with the presence of intact phosphatase and tensin homolog pathway in DU145, which diminishes PI3K-mediated AKT activation. This may also account for the lack of regulation of survival pathway by AZD0530 in DU145. ERK1/2 in PC3 cells on the other hand is not constitutively activated. AKT in PC3, however, is inhibited by AZD0530. AZD0530 treatment results in the removal of the inhibitory phosphorylation of GSK3 3 at S9 in both cell lines (Figure 3d) and therefore increased GSK $3 \beta$ activity, although at a higher concentration than that of $\beta$-catenin and ERK1/2 inhibition seen in DU145. These results suggest that in DU145 and PC3, ERK1/2 and AKT contribute to Src- mediated stabilization of c-Myc, respectively. Furthermore, GSK3 $\beta$ is not responsible for Src-mediated stabilization of c-Myc and $\beta$-catenin in DU145.

\section{AZD0530 is an inhibitor of cell migration}

Src is an integral part of cell migration signaling pathway. We were therefore interested in whether AZD0530 effectively inhibits cell migration. We show that AZD0530 inhibits DU145 and PC3 migration in the Boyden chamber in a dose-dependent manner (Figure 4a).

Src and FAK are known to cross-activate, and enhanced migratory activity is linked to increased FAK expression and activation (Schaller, 2001; Slack et al., 2001). Although autophosphorylation of FAK Y397 is necessary for its activity, Src phosphorylation of FAK Y 576/Y577 is important in enhancing downstream signaling pathways (Parsons, 2003). AZD0530 treatment inhibited phosphorylation of Y576/577 but not Y397 (Figure 4b), indicating that AZD0530 targets Src but not FAK.

P130CAS is also an Src substrate involved in the formation of focal adhesion complexes. As shown in Figure 4b, p130CAS phosphorylation is inhibited by AZD0530. Furthermore, phosphorylation of paxillin, an adaptor protein and an Src-FAK substrate important in recruiting other proteins to the focal adhesion complex, is also inhibited by AZD0530, although at a higher of AZD0530 concentration than Src or FAK. This may reflect the fact that AZD0530 does not inhibit FAK autokinase activity (as reflected by the same level of Y397 phosphorylation), which continues to phosphorylate paxillin.
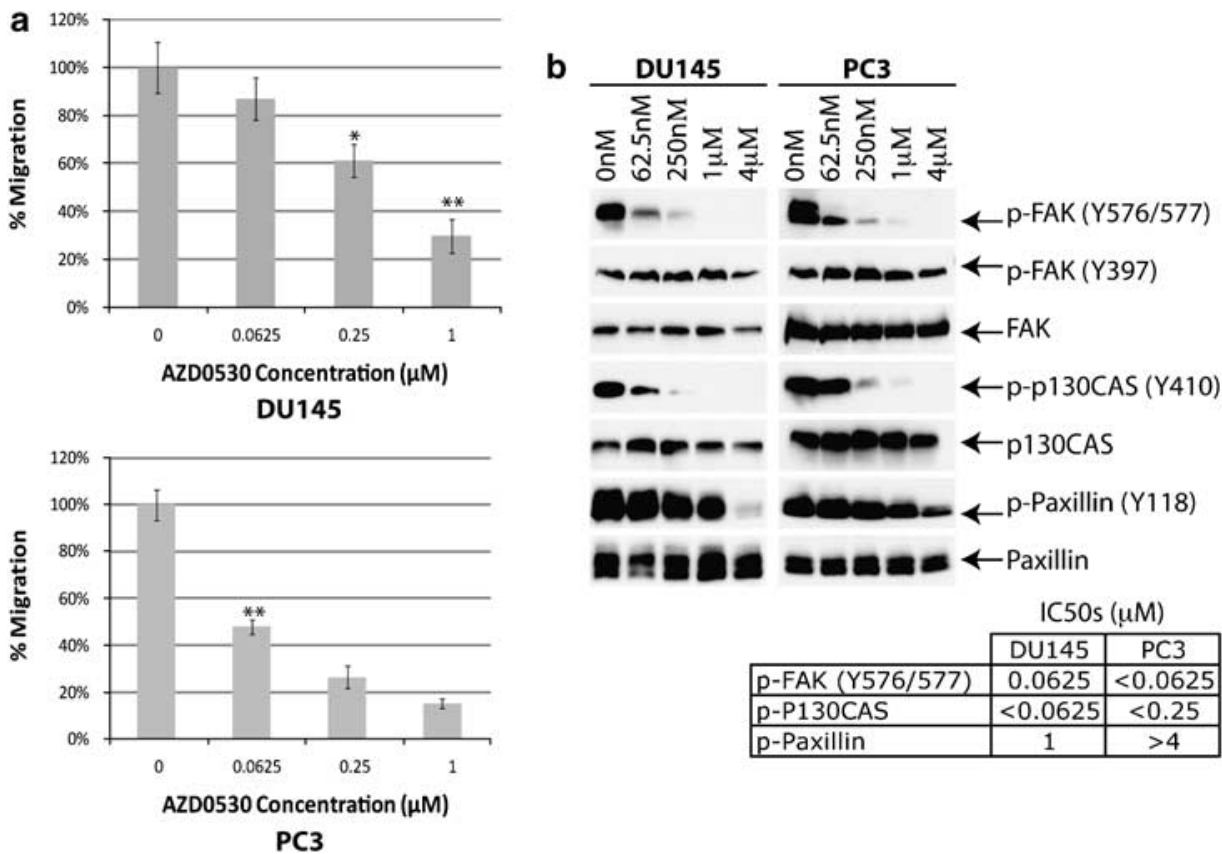

\begin{tabular}{|l|c|c|}
\multicolumn{1}{c}{} & \multicolumn{2}{c}{ IC50s $(\mu \mathrm{M})$} \\
\cline { 2 - 3 } \multicolumn{1}{c|}{} & DU145 & PC3 \\
\hline p-FAK (Y576/577) & 0.0625 & $<0.0625$ \\
\hline p-P130CAS & $<0.0625$ & $<0.25$ \\
\hline p-Paxillin & 1 & $>4$ \\
\hline
\end{tabular}

Figure 4 AZD0530 inhibits cell migration through Src-mediated FAK activation. (a) DU145 (top) and PC3 (bottom) treated with AZD0530 shows dose-dependent decrease in cell migration. (b) Paxillin, p130CAS and p-FAK (Y576/577) phosphorylation were inhibited in DU145 and PC3, following AZD0530 treatment for $30 \mathrm{~min}$. Columns, mean; bars, standard error; $* P<0.05(n=3)$; $* * P<0.01(n=3)$. 


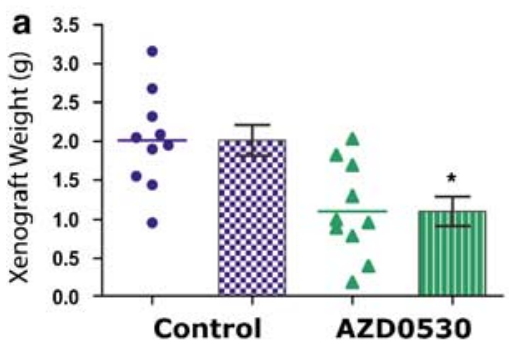

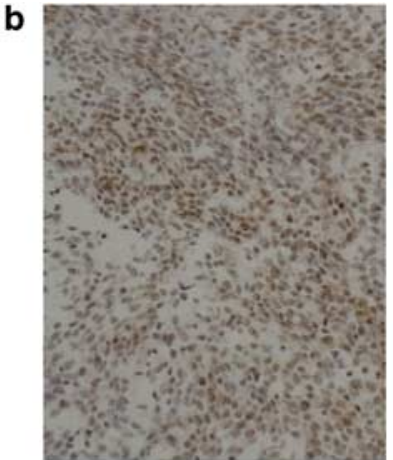

Control

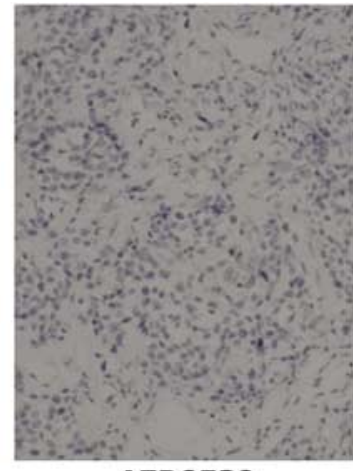

AZD0530

Figure 5 AZD0530 inhibits tumor growth in vivo. (a) $25 \mathrm{mg} / \mathrm{kg}$ of AZD0530 was administered orally daily starting 2 days after orthotopic injection of 2 million DU145 cells. Mice were euthanized after 54 days. Established tumors were harvested and weighed. (b) Immunohistochemical analysis of tumor samples from (a) using specific phospho-Src Y419 antibody as described. Dots and triangles, tumor samples; columns, mean; bars, standard error; ${ }^{*} P<0.05(n=10)$.

\section{AZD0530 is a promising inhibitor of prostate cancer growth in orthotopic SCID mice model}

Utilizing the data we gathered regarding the effects of AZD0530 on in vitro growth and migration of prostate cancer cells, we tested its efficacy in vivo using orthotopically implanted DU145 in mice as our xenograft model. Xenograft mice receiving daily AZD0530 starting 2 days after the implantation have on average $45 \%$ smaller $(P<0.01)$ tumor than control mice (Figure 5a). Src inhibition in vivo by AZD0530 was verified by immunohistochemistry (Figure 5b). Since AZD0530 treatment started shortly after implantation, the decreased tumor size xenograft mice treated with AZD0530 is consistent with the in vitro data of growth inhibition versus apoptosis. This is significant, as previous studies with other $\mathrm{Src}$ inhibitors revealed mostly inhibitory effects on metastasis rather than growth. We were unable to study the effect of AZD0530 on metastasis, as orthotopically implanted DU145 does not metastasize to any significant extent.

\section{Discussion}

Src is involved in prostate cancer growth and migration (Lee et al., 2001, 2004; Nam et al., 2005b; Kotha et al., 2006). We previously reviewed Src's role (Chang et al., 2007) in prostate cancer and wished to further characterize it. We therefore utilized AZD0530 to facilitate identification of Src-driven cell proliferation and migration signaling pathways in prostate cancer. Our data provide further understanding to foster correlative studies and translational research initiatives.

We found an association between higher relative Src activation and aggressive cell phenotypes. There are two Src isoforms and their expression levels are cell linedependent. The origin of these isoforms is presently unclear. Also interesting is that cells with the lowest activated/total Src ratios (LAPC-4, PZ-HPV7, RWPE1) also express the most Src. A possible explanation is that highly active Src is polyubiquitinated and thus quickly degraded (Hakak and Martin, 1999).
In our studies with AZD0530, we see a temporal sequence of its effects. As AZD0530 inhibits Src, changes to phosphorylation signals downstream occurred within minutes. The inhibited phosphorylation of FAK, p130CAS and paxillin quickly decreased cell migration. Taking into account the time it takes for transcriptional inhibition and protein degradation, changes in cyclin D1 and c-Myc levels are relatively late events seen hours post-treatment. Finally, consistent with cell doubling times, cell cycle changes and differential proliferation rates are observed days posttreatment.

We inhibited cell migration and proliferation using AZD0530. Although mechanistic studies of cell migration signaling did not reveal significant mechanistic differences between DU145 and PC3, they appear to regulate cell proliferation through c-Myc and cyclin D1 in different ways. Both cyclin D1 and c-Myc levels are more responsive to AZD0530 in DU145 than PC3. This is attributable to ERK1/2 being active and sensitive to AZD0530 in DU145 but not PC3. Since PC3 has no constitutively active ERK $1 / 2$, it alternatively regulates cyclin D1 and c-Myc through the Src-Ras-AKTGSK3 $\beta$ pathway (Diehl et al., 1998; Morin, 1999; Daaka, 2002). Interestingly, $\beta$-catenin but not GSK3 $\beta$ is affected in a dose-dependent manner by AZD0530 in DU145. Possible explanations of this finding include Src-mediated $\beta$-catenin synthesis (Karni et al., 2005) and phosphorylation (Bjelfman et al., 1990), thus resulting in increased stability (Roura et al., 1999). Common to both cell lines, however, is that Src does not regulate cyclin D1 and c-Myc through STAT3.

Although our studies show that AZD0530 inhibits cell proliferation and migration through various signaling factors, they have relatively higher $\mathrm{IC}_{50}$ values than Src autophosphorylation. Dose-dependent inhibition demonstrated in these assays suggests that Src contributes to their regulation. Nonspecific AZD0530 inhibition, however, cannot be excluded. Nevertheless, there are alternative explanations for these findings. Since phosphorylation status of proteins are dynamic systems dependent on the summative velocities of kinases and phosphatases, partial inhibition of kinase activity may 
not be sufficient to allow phosphorylation status changes if phosphatase velocity remains less than kinase velocity. Furthermore, as shown through c-Myc in DU145 (Figure 3a), the accuracy of determining $\mathrm{IC}_{50}$ values is dependent on the timing of the assay if Src is not the sole regulator of the factor in question, as $1 \mu \mathrm{M}$ of AD0530 decreases c-Myc levels by $90 \%$ at $8 \mathrm{~h}$ but $50 \%$ at $24 \mathrm{~h}$. Actual c-Myc AZD0530 $\mathrm{IC}_{50}$ is therefore less than $1 \mu \mathrm{M}$. Another explanation is that very little Src may be required to activate downstream signals. Individual kinases, such as ERK1/2, have been shown to display cooperative kinetics, which cumulatively in a signal-transduction chain is ultrasensitive to activation, akin to an on-off switch response (Li and Qian, 2003). In other words, very low initial activation of the upstream factor in a signal-transduction chain can be amplified and lead to changes downstream. Our kinetics study of c-Myc, which is regulated by ERK1/2, supports this hypothesis as very small amount of Src activation correlates with a relatively large rise in c-Myc levels (Figure 3a). The combination of ultrasensitivity and dose-dependent residual Src activity at $\mu \mathrm{M}$ AZD0530 concentrations (data not shown) suggests that the effect of Src inhibition on downstream factors decreases exponentially with increasing AZD0530, and therefore increases the $\mathrm{IC}_{50}$ values of Src downstream factors. Extrapolating this further, we can see how the $\mathrm{IC}_{50}$ values of transcription/translation and cell proliferation and migration involving a multitude of factors, many of which are not regulated by $\mathrm{Src}$, can be significantly higher than Src.

The complexity of linking dose inhibition of Src phosphorylation with linear dose inhibition of other molecules and biological events is evident in the dosing and temporal data we present. Although AZD0530 may have other effects, we show it essential to the pathways and events presented. The decreased in vivo tumor growth correlates with significant inhibition of Src autophosphorylation by immunohistochemistry, demonstrating biological and translational relevance. AZD0530 represents an oral drug of low toxicity potentially of high value in the targeted therapy of prostate cancer. The mechanistic differences between the two androgen-independent prostate cancer cell lines DU145 and PC3 highlight the importance of an individualized, pharmacogenomic approach to patients. Studies such as ours are important in linking disease, detailed oncogenic pathway analysis and a targeted therapy in vitro and in vivo. These data have direct translational application to prostate cancer patients entering clinical trials using AZD0530.

\section{Materials and methods}

\section{Cells and reagents}

LNCaP, DU145, PC3, RWPE-1, PZ-HPV7 were obtained from American Type Culture Collection (Manassas, VA, USA). LAPC-4 was provided by Dr Sawyers (Department of Medicine, University of California at Los Angeles, Los Angeles, CA, USA). CWR22Rv1 was provided by Dr Pretlow
(Department of Pathology, Case Western Reserve University, Cleveland, OH, USA). Cell cultures were maintained in RPMI-1640 (Life Technologies Inc., Rockville, MD, USA) with $10 \%$ (LNCaP, RWPE-1), 5\% (DU145, PC3, CWR22Rv1) fetal bovine serum, Dulbecco's Modified Eagle's Medium with $10 \%$ fetal bovine serum (LAPC-4) or keratinocyte serum-free medium with $5 \mathrm{ng} / \mathrm{ml}$ human recombinant epidermal growth factor and $50 \mu \mathrm{g} / \mathrm{ml}$ bovine pituitary extract (PZ-HPV7) supplemented with $100 \mathrm{U} / \mathrm{ml}$ penicillin and $100 \mu \mathrm{g}$ $\mathrm{ml}$ streptomycin at $37^{\circ} \mathrm{C}$ with $5 \% \mathrm{CO}_{2}$. Polyclonal antibodies to AKT, p-AKT (S473), caspase 3, ERK1/2, p-FAK (Y576/ 577), p-GSK3 $\alpha / \beta$ (S21/9), p-p130CAS (Y410), paxillin, p-paxillin (Y118), p-Src (Y419) and STAT3 were obtained from Cell Signaling Technologies (Cambridge, MA, USA). Polyclonal antibodies to FAK and cyclin D1 were obtained from Upstate Biotechnology (Lake Placid, NY, USA) and Santa Cruz Biotechnology (Santa Cruz, CA, USA), respectively. Monoclonal antibodies to p-ERK1/2 (T202/Y204) and p-STAT3 (Y705) were obtained from Cell Signaling Technologies. Monoclonal antibodies to c-Myc and $\alpha$-tubulin were obtained from Santa Cruz Biotechnology. Monoclonal antibodies to p-FAK (Y397) and p130CAS were obtained from BD Biosciences (San Jose, CA, USA). Monoclonal antibodies to $\mathrm{c}-\mathrm{Myc}$ and $\beta$-catenin were obtained from Santa Cruz Biotechnology. Monoclonal antibodies to GSK3 $\beta$, Src and $\beta$-actin were obtained from Cell Signaling Technologies, Upstate Biotechnology and Sigma-Aldrich (St Louis, MO, USA), respectively. AZD0530 was obtained from AstraZeneca International (Alderley Park, UK). 3-[4,5-dimethylthiazol-2yl]-2,5-diphenyl tetrazolium bromide was obtained from Sigma-Aldrich. The DAKO Envision + Kit was obtained from DAKO North American Inc. (Carpinteria, CA, USA). Diff-Quick set was purchased from Dade Behring Inc. (Newark, DE, USA). Dimethyl sulfoxide was obtained from Fisher Scientific (Pittsburgh, PA, USA). DNase-free RNase was obtained from Fermentas (Hanover, MD, USA). Fibronectin was obtained from Roche Applied Science (Indianapolis, IN, USA). Propidium iodide was obtained from Boehringer Mannheim Corporation (Indianapolis).

\section{Boyden chamber cell migration assay}

Cell migration assay was performed as described previously and performed in triplicates (Evans et al., 1991). Lower wells of the microchamber were filled with $50 \mu \mathrm{g} / \mathrm{ml}$ of fibronectin in $0.1 \%$ BSA phenol-red free RPMI-1640 media as chemoattractant. Both chambers contained varying concentrations of AZD0530 $(0-2 \mu \mathrm{M})$. Cells were allowed to migrate for $4 \mathrm{~h}$ followed by Diff-Quick stain and counted as an average of five fields.

\section{Cell cycle analysis}

Cells were plated in triplicate in $60 \mathrm{~mm}$ dishes followed by AZD0530 $(1 \mu \mathrm{M})$ treatment for 48 (DU145) and 72 (PC3) hours, accounting for slower proliferation rate in PC3 cells. Growth media were removed and saved. Cells were washed with phosphate-buffered saline (PBS) and the wash saved with the growth media. Remaining cells were trypsinized and placed together with growth media and PBS. Cells were pelleted and resuspended in $75 \%$ ethanol followed by overnight storage at $-20^{\circ} \mathrm{C}$. Cells were centrifuged, washed with PBS, resuspended in PBS containing $10 \mu \mathrm{g} / \mathrm{ml}$ DNase-free RNase, and incubated in $37^{\circ} \mathrm{C}$ for $45 \mathrm{~min}$. Final propidium iodide concentration of $0.05 \mathrm{mg} / \mathrm{ml}$ was added and incubated at room temperature for $20 \mathrm{~min}$. Cell clumps were filtered. Cell DNA content was measured on Coulter Epics XL flow cytometer (Beckman Coulter, Miami, FL, USA) and cell cycle phase was analysed 
using Phoenix Multicycle (Phoenix Flow Systems, San Diego, CA, USA).

\section{Chromatin immunoprecipitation assay}

Chromatin immunoprecipiation assay was performed as described previously (Vinall et al., 2006). Primers for cyclin D1 and c-Myc promoter regions are as follows: $5^{\prime}$-GCTC TCCACTTGCCCCTTTTA-3' (c-Myc, forward), 5'-GTTCCC AATTTCTCAGCC-3 (c-Myc, reverse), 5'-GGGAGGAATT CACCCTGAAA-3' (cyclin D1, forward), 5'-CCTGCCCCA AATTAAGAAAA-3' (cyclin D1, reverse).

\section{3-[4,5-dimethylthiazol-2-yl]-2,5-diphenyl tetrazolium bromide cell proliferation assay}

Cells were seeded overnight 2000 cells per well in triplicate in 96-well plates followed by single treatment of AZD0530 $(62.5 \mathrm{nM}-16 \mu \mathrm{M})$. On post-treatment days 1,3 and 5 , growth medium was removed followed by addition of $0.2 \mathrm{ml}$ dimethyl sulfoxide per well and continuous shaking of plates at 200 rotations per minute for $15 \mathrm{~min}$. Colorimetric measurement was performed at $450 \mathrm{~nm}$.

\section{Orthotopic mouse model}

Severe combined immunodeficiency (CB17) mice 4 weeks of age were obtained from Harlan Sprague-Dawley and housed in pathogen-free conditions. Mice were placed in anesthesia with $2 \%$ isoflurane air. Two million DU145 cells were mixed with Matrigel in 1:1 ratio by volume and injected into a lateral lobe of the prostate as previously described (Stephenson et al., 1992). Twenty-five milligrams per kilogram of AZD0530 dissolved in $0.5 \%$ hydroxypropyl methylcellulose (SigmaAldrich), $0.1 \%$ Tween 80 (Sigma-Aldrich) was orally given daily 2 days post-operation. Mice were euthanized 54 days post-operation and tumors harvested. Animal housing and experimental conditions were in compliance with the protocol approved by the Institutional Animal Care and Use Committee at the University of California, Davis.

\section{References}

Albanese C, Johnson J, Watanabe G, Eklund N, Vu D, Arnold A et al. (1995). Transforming p21 ras mutants and c-Ets-2 activate the cyclin D1 promoter through distinguishable regions. $J$ Biol Chem 270: 23589-23597.

Bang YJ, Pirnia F, Fang WG, Kang WK, Sartor O, Whitesell L et al. (1994). Terminal neuroendocrine differentiation of human prostate carcinoma cells in response to increased intracellular cyclic AMP. Proc Natl Acad Sci USA 91: 5330-5334.

Barone MV, Courtneidge SA. (1995). Myc but not Fos rescue of PDGF signalling block caused by kinase-inactive Src. Nature 378 : 509-512.

Biscardi JS, Ishizawar RC, Silva CM, Parsons SJ. (2000). Tyrosine kinase signalling in breast cancer: epidermal growth factor receptor and c-Src interactions in breast cancer. Breast Cancer Res 2: 203-210.

Bjelfman C, Meyerson G, Cartwright CA, Mellstrom K, Hammerling U, Pahlman S. (1990). Early activation of endogenous pp60src kinase activity during neuronal differentiation of cultured human neuroblastoma cells. Mol Cell Biol 10: 361-370.

Bowman T, Broome MA, Sinibaldi D, Wharton W, Pledger WJ, Sedivy JM et al. (2001). Stat3-mediated Myc expression is required for Src transformation and PDGF-induced mitogenesis. Proc Natl Acad Sci USA 98: 7319-7324.

Bromann PA, Korkaya H, Courtneidge SA. (2004). The interplay between Src family kinases and receptor tyrosine kinases. Oncogene 23: 7957-7968.
Reverse transcription- $P C R$

The Versagene RNA purification kit (Qiagen USA, Valencia, CA, USA) was used for mRNA extraction as per the manufacturer's instructions. RNA was reverse transcribed to cDNA using oligo-dT primers and Moloney murine leukemia virus reverse transcriptase (Promega, Madison, WI, USA) as per the manufacturer's instructions. Reverse transcriptase products were used as templates for PCR. The primers are as follows: 5'-ACCGAGGAGAATGTCAAGAGGC-3' (c-Myc, forward), 5'-CGTCGTTTCCGCAACAAGTC-3' (c-Myc, reverse), 5'-TGTTTGCAAGCAGGACTTTG-3' (cyclin D1, forward), 5'-TCATCCTGGCAATGTGAGAA-3' (cyclin D1, reverse).

\section{Statistics}

Data were analysed using Statview version 5.1 (SAS, Cary, NC, USA).

\section{Western blotting}

Western blotting was performed as described previously (Qiu et al., 1998). Membranes were incubated overnight in $4{ }^{\circ} \mathrm{C}$ with primary antibodies in 5\% non-fat milk tris-buffered saline Tween-20 followed by wash and 1-h room temperature incubation with respective horseradish peroxidase-conjugated secondary antibodies. Antibody-epitope binding was detected using SuperSignal West Pico Chemiluminescent Substrate (Pierce, Rockford, IL, USA).

\section{Acknowledgements}

This study was supported by National Institutes of Health Grant KO8 DK60748-01 (CPE), RO1 DK52659 (H-JK) and Department of Defense Grant PC040161 (CPE). The contents of this report are solely the responsibility of the authors and do not necessarily represent the official views of the National Institutes of Health or the Department of Defense.

Chang YM, Kung HJ, Evans CP. (2007). Nonreceptor tyrosine kinases in prostate cancer. Neoplasia 9: 90-100.

Chen G, Shukeir N, Potti A, Sircar K, Aprikian A, Goltzman D et al. (2004). Up-regulation of Wnt-1 and beta-catenin production in patients with advanced metastatic prostate carcinoma: potential pathogenetic and prognostic implications. Cancer 101: 1345-1356.

Cheng JQ, Lindsley CW, Cheng GZ, Yang H, Nicosia SV. (2005). The Akt/PKB pathway: molecular target for cancer drug discovery. Oncogene 24: 7482-7492.

Cronauer MV, Schulz WA, Ackermann R, Burchardt M. (2005). Effects of WNT/beta-catenin pathway activation on signaling through T-cell factor and androgen receptor in prostate cancer cell lines. Int J Oncol 26: 1033-1040.

Cross DA, Alessi DR, Cohen P, Andjelkovich M, Hemmings BA. (1995). Inhibition of glycogen synthase kinase-3 by insulin mediated by protein kinase B. Nature 378: 785-789.

Daaka Y. (2002). Mitogenic action of LPA in prostate. Biochim Biophys Acta 1582: 265-269.

de la Taille A, Rubin MA, Chen MW, Vacherot F, de Medina SG, Burchardt $\mathrm{M}$ et al. (2003). Beta-catenin-related anomalies in apoptosis-resistant and hormone-refractory prostate cancer cells. Clin Cancer Res 9: 1801-1807.

Desai SJ, Ma AH, Tepper CG, Chen HW, Kung HJ. (2006). Inappropriate activation of the androgen receptor by nonsteroids: involvement of the Src kinase pathway and its therapeutic implications. Cancer Res 66: 10449-10459. 
Devi GR, Oldenkamp JR, London CA, Iversen PL. (2002). Inhibition of human chorionic gonadotropin beta-subunit modulates the mitogenic effect of c-myc in human prostate cancer cells. Prostate 53: $200-210$.

Diehl JA, Cheng M, Roussel MF, Sherr CJ. (1998). Glycogen synthase kinase-3beta regulates cyclin D1 proteolysis and subcellular localization. Genes Dev 12: 3499-3511.

Dominguez-Sola D, Dalla-Favera R. (2004). PINning down the c-Myc oncoprotein. Nat Cell Biol 6: 288-289.

Dong JT. (2006). Prevalent mutations in prostate cancer. J Cell Biochem 97: 433-447.

Evans CP, Walsh DS, Kohn EC. (1991). An autocrine motility factor secreted by the Dunning R-3327 rat prostatic adenocarcinoma cell subtype AT2.1. Int J Cancer 49: 109-113.

Farkas A, Szatmari E, Orbok A, Wilhelm I, Wejksza K, Nagyoszi P et al. (2005). Hyperosmotic mannitol induces Src kinase-dependent phosphorylation of beta-catenin in cerebral endothelial cells. $J$ Neurosci Res 80: 855-861.

Furstoss O, Dorey K, Simon V, Barila D, Superti-Furga G, Roche S. (2002). c-Abl is an effector of Src for growth factor-induced c-myc expression and DNA synthesis. EMBO J 21: 514-524.

Gao L, Zhang L, Hu J, Li F, Shao Y, Zhao D et al. (2005). Downregulation of signal transducer and activator of transcription 3 expression using vector-based small interfering RNAs suppresses growth of human prostate tumor in vivo. Clin Cancer Res 11: 6333-6341.

Golas JM, Arndt K, Etienne C, Lucas J, Nardin D, Gibbons J et al. (2003). SKI-606, a 4-anilino-3-quinolinecarbonitrile dual inhibitor of Src and Abl kinases, is a potent antiproliferative agent against chronic myelogenous leukemia cells in culture and causes regression of K562 xenografts in nude mice. Cancer Res 63: 375-381.

Gray MJ, Zhang J, Ellis LM, Semenza GL, Evans DB, Watowich SS et al. (2005). HIF-1alpha, STAT3, CBP/p300 and Ref-1/APE are components of a transcriptional complex that regulates Srcdependent hypoxia-induced expression of VEGF in pancreatic and prostate carcinomas. Oncogene 24: 3110-3120.

Guo Z, Dai B, Jiang T, Xu K, Xie Y, Kim O et al. (2006). Regulation of androgen receptor activity by tyrosine phosphorylation. Cancer Cell 10: 309-319.

Hakak Y, Martin GS. (1999). Ubiquitin-dependent degradation of active Src. Curr Biol 9: 1039-1042.

Hauck CR, Hsia DA, Puente XS, Cheresh DA, Schlaepfer DD. (2002). FRNK blocks v-Src-stimulated invasion and experimental metastases without effects on cell motility or growth. EMBO J 21: 6289-6302.

Hennequin LF, Allen J, Breed J, Curwen J, Fennell M, Green TP et al. (2006). N-(5-Chloro-1,3-benzodioxol-4-yl)-7-[2-(4-methylpiperazin1-yl)ethoxy]-5- (tetrahydro-2H-pyran-4-yloxy)quinazolin-4-amine, a novel, highly selective, orally available, dual-specific c-Src/Abl kinase inhibitor. J Med Chem 49: 6465-6488.

Hiscox S, Morgan L, Green TP, Barrow D, Gee J, Nicholson RI. (2006). Elevated Src activity promotes cellular invasion and motility in tamoxifen resistant breast cancer cells. Breast Cancer Res Treat 97: $263-274$.

Jemal A, Siegel R, Ward E, Hao Y, Xu J, Murray T et al. (2008). Cancer statistics, 2008. CA Cancer J Clin 58: 71-96.

Karni R, Gus Y, Dor Y, Meyuhas O, Levitzki A. (2005). Active Src elevates the expression of beta-catenin by enhancement of capdependent translation. Mol Cell Biol 25: 5031-5039.

Kim D, Rath O, Kolch W, Cho KH. (2007). A hidden oncogenic positive feedback loop caused by crosstalk between Wnt and ERK pathways. Oncogene 26: 4571-4579.

Kotha A, Sekharam M, Cilenti L, Siddiquee K, Khaled A, Zervos AS et al. (2006). Resveratrol inhibits Src and Stat 3 signaling and induces the apoptosis of malignant cells containing activated Stat 3 protein. Mol Cancer Ther 5: 621-629.

Lee D, Gautschi O. (2006). Clinical development of SRC tyrosine kinase inhibitors in lung cancer. Clin Lung Cancer 7: 381-384.

Lee LF, Guan J, Qiu Y, Kung HJ. (2001). Neuropeptide-induced androgen independence in prostate cancer cells: roles of nonreceptor tyrosine kinases Etk/Bmx, Src, and focal adhesion kinase. Mol Cell Biol 21: 8385-8397.

Lee LF, Louie MC, Desai SJ, Yang J, Chen HW, Evans CP et al. (2004). Interleukin-8 confers androgen-independent growth and migration of LNCaP: differential effects of tyrosine kinases Src and FAK. Oncogene 23: 2197-2205.

Li G, Qian H. (2003). Sensitivity and specificity amplification in signal transduction. Cell Biochem Biophys 39: 45-59.

Lombardo LJ, Lee FY, Chen P, Norris D, Barrish JC, Behnia K et al. (2004). Discovery of N-(2-chloro-6-methyl- phenyl)-2-(6-(4-(2-hydroxyethyl)- piperazin-1-yl)-2-methylpyrimidin-4- ylamino)thiazole5-carboxamide (BMS-354825), a dual Src/Abl kinase inhibitor with potent antitumor activity in preclinical assays. $J$ Med Chem 47: $6658-6661$.

Morin PJ. (1999). beta-catenin signaling and cancer. Bioessays 21: $1021-1030$.

Nam S, Buettner R, Turkson J, Kim D, Cheng JQ, Muehlbeyer S et al. (2005a). Indirubin derivatives inhibit Stat3 signaling and induce apoptosis in human cancer cells. Proc Natl Acad Sci USA 102: 5998-6003.

Nam S, Kim D, Cheng JQ, Zhang S, Lee JH, Buettner R et al. (2005b). Action of the Src family kinase inhibitor, dasatinib (BMS-354825), on human prostate cancer cells. Cancer Res 65: 9185-9189.

Park SI, Zhang J, Phillips KA, Araujo JC, Najjar AM, Volgin AY et al. (2008). Targeting SRC family kinases inhibits growth and lymph node metastases of prostate cancer in an orthotopic nude mouse model. Cancer Res 68: 3323-3333.

Parsons JT. (2003). Focal adhesion kinase: the first ten years. J Cell Sci 116: $1409-1416$.

Planas-Silva MD, Bruggeman RD, Grenko RT, Stanley Smith J. (2006). Role of c-Src and focal adhesion kinase in progression and metastasis of estrogen receptor-positive breast cancer. Biochem Biophys Res Commun 341: 73-81.

Prathapam T, Tegen S, Oskarsson T, Trumpp A, Martin GS. (2006). Activated Src abrogates the Myc requirement for the G0/G1 transition but not for the G1/S transition. Proc Natl Acad Sci USA 103: 2695-2700.

Qiu Y, Robinson D, Pretlow TG, Kung HJ. (1998). Etk/Bmx, a tyrosine kinase with a pleckstrin-homology domain, is an effector of phosphatidylinositol $3^{\prime}$-kinase and is involved in interleukin 6induced neuroendocrine differentiation of prostate cancer cells. Proc Natl Acad Sci USA 95: 3644-3649.

Quelle DE, Ashmun RA, Shurtleff SA, Kato JY, Bar-Sagi D, Roussel MF et al. (1993). Overexpression of mouse D-type cyclins accelerates G1 phase in rodent fibroblasts. Genes Dev 7: 1559-1571.

Roura S, Miravet S, Piedra J, Garcia de Herreros A, Dunach M. (1999). Regulation of E-cadherin/Catenin association by tyrosine phosphorylation. J Biol Chem 274: 36734-36740.

Rovin JD, Frierson Jr HF, Ledinh W, Parsons JT, Adams RB. (2002). Expression of focal adhesion kinase in normal and pathologic human prostate tissues. Prostate 53: 124-132.

Schaller MD. (2001). Biochemical signals and biological responses elicited by the focal adhesion kinase. Biochim Biophys Acta 1540: $1-21$.

Sears RC. (2004). The life cycle of C-myc: from synthesis to degradation. Cell Cycle 3: 1133-1137.

Slack JK, Adams RB, Rovin JD, Bissonette EA, Stoker CE, Parsons JT. (2001). Alterations in the focal adhesion kinase/Src signal transduction pathway correlate with increased migratory capacity of prostate carcinoma cells. Oncogene 20: 1152-1163.

Steiner MS, Anthony CT, Lu Y, Holt JT. (1998). Antisense c-myc retroviral vector suppresses established human prostate cancer. Hum Gene Ther 9: 747-755.

Stephenson RA, Dinney CP, Gohji K, Ordonez NG, Killion JJ, Fidler IJ. (1992). Metastatic model for human prostate cancer using orthotopic implantation in nude mice. $J$ Natl Cancer Inst 84: 951-957.

Taj MM, Tawil RJ, Engstrom LD, Zeng Z, Hwang C, Sanda MG et al. (2001). Mxil, a Myc antagonist, suppresses proliferation of DU145 human prostate cells. Prostate 47: 194-204. 
Tsai YT, Su YH, Fang SS, Huang TN, Qiu Y, Jou YS et al. (2000). Etk, a Btk family tyrosine kinase, mediates cellular transformation by linking Src to STAT3 activation. Mol Cell Biol 20: 2043-2054.

Unni E, Sun S, Nan B, McPhaul MJ, Cheskis B, Mancini MA et al. (2004). Changes in androgen receptor nongenotropic signaling correlate with transition of $\mathrm{LNCaP}$ cells to androgen independence. Cancer Res 64: 7156-7168.

Verras M, Sun Z. (2006). Roles and regulation of Wnt signaling and beta-catenin in prostate cancer. Cancer Lett 237: 22-32.

Vinall RL, Tepper CG, Shi XB, Xue LA, Gandour-Edwards R, de Vere White RW. (2006). The R273H p53 mutation can facilitate the androgen-independent growth of LNCaP by a mechanism that involves $\mathrm{H} 2$ relaxin and its cognate receptor LGR7. Oncogene 25: 2082-2093.

Watanabe G, Howe A, Lee RJ, Albanese C, Shu IW, Karnezis AN et al. (1996). Induction of cyclin D1 by simian virus 40 small tumor antigen. Proc Natl Acad Sci USA 93: 12861-12866.

Yeatman TJ. (2004). A renaissance for SRC. Nat Rev Cancer 4: $470-480$

Yuan ZL, Guan YJ, Chatterjee D, Chin YE. (2005). Stat3 dimerization regulated by reversible acetylation of a single lysine residue. Science 307: 269-273.

Zhu S, Bjorge JD, Fujita DJ. (2007). PTP1B contributes to the oncogenic properties of colon cancer cells through Src activation. Cancer Res 67: 10129-10137. 


\title{
Regulation of Id1 Expression by Src: Implications for Targeting of the Bone Morphogenetic Protein Pathway in Cancer
}

\author{
Oliver Gautschi, ${ }^{1,2}$ Clifford G. Tepper, ${ }^{2,3}$ Phillip R. Purnell, ${ }^{2}$ Yoshihiro Izumiya, ${ }^{3}$ \\ Christopher P. Evans, ${ }^{4}$ Tim P. Green, ${ }^{5}$ Pierre Y. Desprez, ${ }^{6}$ Primo N. Lara, ${ }^{2}$ \\ David R. Gandara, ${ }^{2}$ Philip C. Mack, ${ }^{2}$ and Hsing-Jien Kung ${ }^{2,3}$
}

${ }^{1}$ Department of Medical Oncology, Bern University Hospital, Bern, Switzerland; ${ }^{2}$ University of California Davis Cancer Center, Departments

of ${ }^{3}$ Biochemistry and Molecular Medicine, and ${ }^{4}$ Urology, School of Medicine, University of California Davis, Sacramento, California;

${ }^{5}$ AstraZeneca Pharmaceuticals, Alderley Park, United Kingdom; and ${ }^{6}$ California Pacific Medical Center, Cancer Research Institute,

San Francisco, California

\begin{abstract}
Deregulated activation of the Src tyrosine kinase and heightened Idl expression are independent mediators of aggressive tumor biology. The present report implicates Src signaling as a critical regulator of Id1 gene expression. Microarray analyses showed that Id family genes were among the most highly down-regulated by incubation of A549 lung carcinoma cells with the small-molecule Src inhibitor AZD0530. Id1 transcript and protein levels were potently reduced in a dose-dependent manner concomitantly with the reduction of activated Src levels. These effects were conserved across a panel of lung, breast, prostate, and colon cancer cell lines and confirmed by the ability of PP2, Src siRNA, and Srcblocking peptides to suppress Id1 expression. PP2, AZD0530, and dominant-negative Src abrogated Idl promoter activity, which was induced by constitutively active Src. The Srcresponsive region of the Idl promoter was mapped to a region 1,199 to 1,360 bps upstream of the translation start site and contained a Smad-binding element. Src was also required for bone morphogenetic protein-2 (BMP-2)-induced Id1 expression and promoter activity, was moderately activated by BMP2, and complexed with Smad1/5. Conversely, Src inhibitors blocked Smad1/5 nuclear translocation and binding to the Src-responsive region of the Idl promoter. Consistent with a role for Src and Idl in cancer cell invasion, Src inhibitors and Idl siRNA decreased cancer cell invasion, which was increased by Idl overexpression. Taken together, these results reveal that Src positively interacts with the BMP-Smad-Id pathway and provide new ways for targeted inhibition of Id1. [Cancer Res 2008;68(7):2250-8]
\end{abstract}

\section{Introduction}

The Src family of nonreceptor protein tyrosine kinases contains nine members, including Src, Yes, Fyn, Lyn, Lck, Hck, Fgr, Blk, and Yrk (1). Src is activated by growth factor receptors, cytokine receptors, protein tyrosine phosphatase 1B, CAS, and focal adhesion kinase (FAK). Src interacts with a network of intracellular signaling pathways, including the integrin/FAK pathway, $\beta$-catenin/Wnt, RAS-MEK, phosphatidylinositol-3-OH kinase-AKT

Note: Supplementary data for this article are available at Cancer Research Online (http://cancerres.aacrjournals.org/).

Requests for reprints: Oliver Gautschi, Department of Medical Oncology, Bern University Hospital, 3010 Bern, Switzerland. Phone: 41-31-632-41-14; Fax: 41-31-632-

41-20; E-mail: oliver.gautschi@insel.ch.

(c)2008 American Association for Cancer Research.

doi:10.1158/0008-5472.CAN-07-6403 and Janus-activated kinase-STAT pathways. These complex interactions explain why Src is involved in a large number of cellular functions including adhesion, migration, invasion, survival, proliferation, differentiation, inflammation, and angiogenesis. Activated Src induced transformation in fibroblasts, and Src kinases were found frequently to be overexpressed and activated in human cancer (2). This prompted the development of a number of small-molecule Src kinase inhibitors that reduced cancer invasion and metastasis in preclinical models. For example, AZD0530, a potent and selective small-molecule inhibitor of Src kinase, is currently being tested in phase II clinical trials in patients with cancer $(3,4)$. Apart from their promising clinical utility, smallmolecule inhibitors of Src possess the potential to identify genes regulated by Src signaling and putative effector molecules.

The inhibitor of DNA binding/differentiation (Id) family of helixloop-helix (HLH) proteins comprises four members (Id1-4) that all lack a DNA-binding domain (5). Id proteins associate with and inhibit the function of basic HLH transcription factors, including MyoD and E-proteins, to regulate normal cell fate determination, differentiation, and angiogenesis (6-9). Expression of Idl is induced by bone morphogenetic proteins (BMP), which activate Smad1/5 via the BMP-receptors (10-13). Activated Smad1/5 binds Smad4, translocates to the nucleus, binds to Smad-binding elements in the Id1 promoter, and recruits transcription factors and coactivators that induce Id1 transcription (14-16). In contrast, transforming growth factor (TGF) $\beta$ can repress the Id 1 promoter by activation of Smad3 (17). BMPs and Idl are overexpressed in various cancer types and are associated with an aggressive, invasive phenotype (18-22). Expression of Id gene family expression is mediated by oncogenic RAS, MYC, and TP53 gain of function mutation $(12,23-25)$. Idl promotes invasion by production of a $120-\mathrm{kDa}$ gelatinase, mediates tumor angiogenesis by production of vascular endothelial growth factor, facilitates hormone-independent growth, and is involved in the resistance of cancer cells against cytotoxic drugs $(19,26,27)$. Due to its role in cell differentiation and in vascular endothelial cells, Idl has also been implicated in the biology of cancer stem cells and tumor angiogenesis $(8,28,29)$. Altogether, there is strong evidence that Idl is an interesting drug target in cancer (30). However, strategies of Id targeting have thus far been limited to methods of gene silencing in the laboratory. Thus, the availability of pharmaceutical methods to inhibit Id1 in vivo may greatly advance the understanding of the role of Id1 in the biology, therapy, and prevention of cancer.

Here, we show that Src interacts with and is a positive modulator of the BMP-2/Smad1/Id1 signaling pathway in lung cancer cells, suggesting an important role for Id1 in Src-mediated invasion. We also provide evidence that Src inhibition by small 
molecules significantly reduces the level of Id1 in lung, breast, prostate, and colon cancer cells, thereby providing a potential way to target Id1 in vivo.

\section{Materials and Methods}

Cell lines and reagents. The following cell lines were obtained from the American Type Culture Collection: A549, H460, LNCaP, PC-3, T47D, MDAMB231, HCT-116, and HT-29. Cells were cultured in RPMI (LNCaP and PC-3) or DMEM (all other cell lines) plus 10\% filtered, heat-inactivated fetal bovine serum (FBS). PP2 (Calbiochem) and AZD0530 (AstraZeneca) were solubilized in DMSO to obtain a 10 and $1 \mathrm{mmol} / \mathrm{L}$ stock solution, respectively. The Src-blocking peptides CpraYKYY- $\beta$ Ala-r7 and CpraYKYY- $\beta A l a-k 7$ (provided by Dr. Kit Lam, University of California Davis Cancer Center, Sacramento, CA) were solubilized in sterile $\mathrm{H}_{2} \mathrm{O}$ to obtain a $25 \mathrm{mmol} / \mathrm{L}$ stock solution (31). Recombinant human BMP-2 (R\&D Systems) was reconstituted in $4 \mathrm{nmol} / \mathrm{L} \mathrm{HCl}$ containing $0.1 \%$ bovine serum albumin (BSA) to obtain a $10 \mu \mathrm{g} / \mathrm{mL}$ stock solution. Stock solutions were stored at $-20^{\circ} \mathrm{C}$ and diluted in DMEM for each experiment.

Microarray gene expression profiling. RNA isolation, RNA purification, and genome-wide expression profiling using Human Genome U133 Plus 2.0 GeneChip arrays (Affymetrix) was performed according to the manufacturer's protocols and as described previously (24). Initial data processing (e.g., signal detection and scaling) for each chip was performed using Affymetrix GeneChip Operating Software. Model-based expression analysis (using the perfect match-mismatch model) was used to identify differentially expressed genes using DNA-Chip Analyzer software (dChip; ref. 32). For this, signals from all of the arrays were normalized to the array that had the median overall intensity. Criteria for the selection of genes exhibiting significant expression changes included an average fold change of $\geq 2.0$ (AZD0530/DMSO), $P$ values of $\leq 0.05$, and at least 100 units of change between the two treatments being tested.

Reverse transcription-PCR. Total RNA was extracted using the Trizol protocol (Invitrogen) and cDNA was generated using M-MuLV reverse
Figure 1. Id gene expression is down-regulated by Src inhibition in cancer cells. A549 cells were incubated with increasing concentrations of AZD0530, and control cells were incubated with DMSO. A, RNA was isolated after $24 \mathrm{~h}$, and real-time RT-PCR for Id1 RNA and 18S rRNA was performed in triplicates using Sybr Green. Id1 levels were normalized

for $18 \mathrm{~S}$ rRNA. Columns, mean relative to control; bars, SEs. $B$, protein was isolated after $48 \mathrm{~h}$ of incubation with AZD0530, and Western blotting was performed to determine the levels of pY419-Src, Src, Id1, and actin. $C$, lung (A549 and H460), breast (T47D and MDA-MB231), prostate (LNCaP and PC-3), and colon (HCT-116 and HT-29) cancer cells were selected according to their reported invasive potential, and Western blotting was performed to compare the basal levels of pY419-Src, Src, Id1, and actin. $D$, cells were incubated for $48 \mathrm{~h}$ with PP2 $(10 \mu \mathrm{mol} / \mathrm{L})$ or AZD0530 (1 $\mu \mathrm{mol} / \mathrm{L} ; A Z D)$. Control cells were incubated with DMSO. Western blotting was performed to determine the levels of pY419-Src, Id1, and actin.

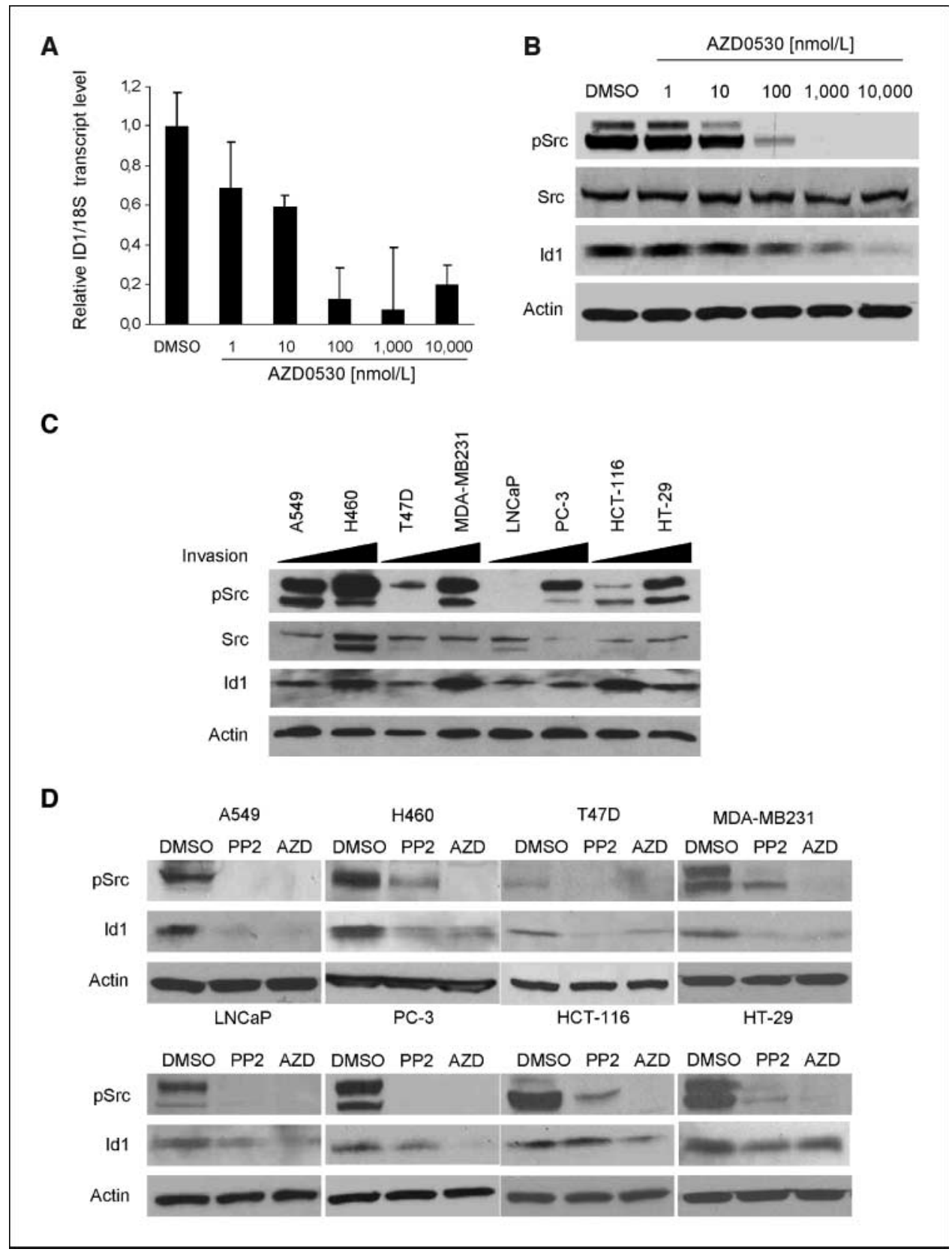


A

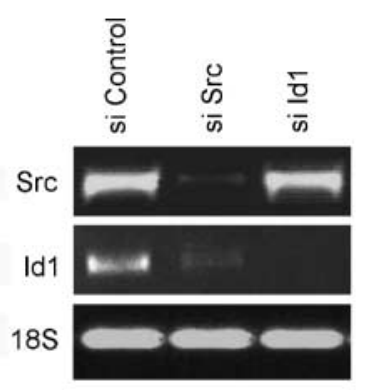

C

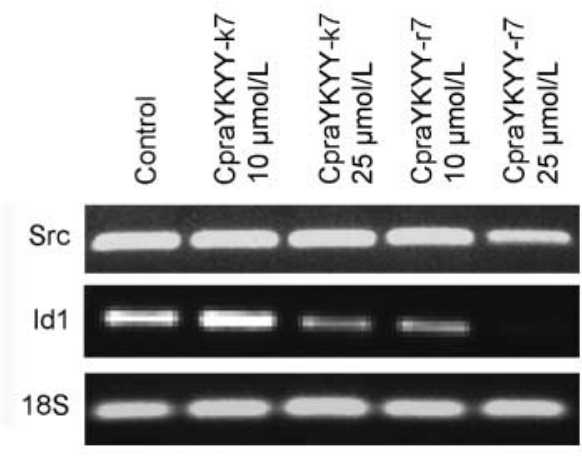

B

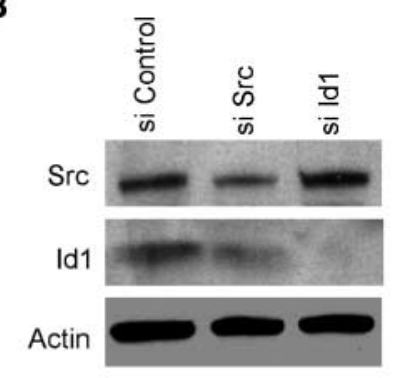

D

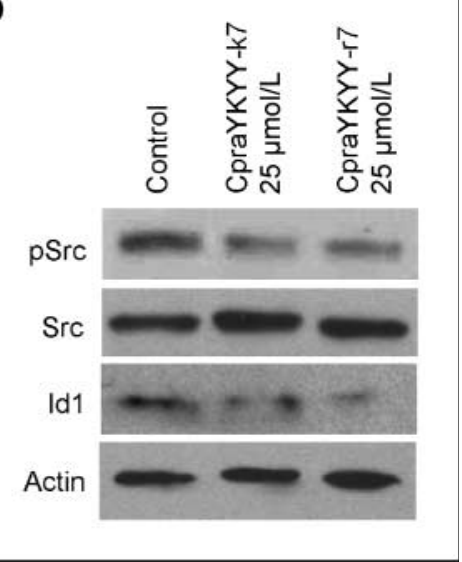

Figure 2. Reduction of Id1 mRNA and protein levels by Src siRNA and blocking peptides. $A$, A549 cells were incubated with Src siRNA, Id1 siRNA, or nontargeting control siRNA (each at $100 \mathrm{nmol} / \mathrm{L} ; 24 \mathrm{~h}$ ). RNA was isolated and RT-PCR was performed using specific primers for Src mRNA, Id1 mRNA, and 18S rRNA. B, protein was isolated for Western blotting and probing for Src, Id1, and actin. C, A549 cells were incubated with the Src-blocking peptides CpraYKYY- $\beta A$ la-k7 and CpraYKYY- $\beta$ Ala-r7 at the concentrations indicated for $24 \mathrm{~h}$. RNA was isolated and RT-PCR was performed using specific primers for Src mRNA, Id1 mRNA, and 18S rRNA. D, Western blotting was performed to determine the levels of pY419-Src, Src, Id1, and actin. transcriptase (Fermentas). For PCR primer sequences and annealing temperatures, see Supplementary Fig. S2. PCR products were loaded onto $1 \%$ agarose gels and run at $110 \mathrm{~V}$ for $1 \mathrm{~h}$.

Real-time RT-PCR. Quantitative real-time PCR was performed using iQ Sybr Green Supermix and the iCycler detection system (Bio-Rad). Primer sequences were as follows: ID1 forward, $5^{\prime}$-CTCTACGACATGAACGGCTGT3'; ID1 reverse, 5'-TGCTCACCTTGCGGTTCTG-3'; 18S forward, 5'-CGCCGCTAGAGGTGAAATTCT-3'; and 18S reverse, 5'-CGAACCTCCGACTTTCGTTCT-3'. Standard dilutions, melting curve analysis, and agarose gel electrophoresis of PCR products were performed to confirm accuracy. Triplicate Idl expression values were normalized for $18 \mathrm{~S}$ rRNA, and data were processed using Q-GENE software (33).

Western blotting. Cells were lysed in radioimmunoprecipitation assay (RIPA) buffer on ice for $30 \mathrm{~min}$ and protein concentrations were determined using the bicinchoninic acid protein assay (Pierce Biotechnology). Equal amounts of protein were electrophoresed on polyacrylamide gradient gels (4-20\%) and transferred onto nitrocellulose membranes by semidry blotting. Membranes were blocked for $1 \mathrm{~h}$ with TBS containing 5\% nonfat dry milk and incubated overnight with antibodies against Src (Upstate), phospho-Src family (Cell Signaling), Idl (Biocheck), pS463/465-Smad1/5 (Upstate), Smad1/5/8 (Santa Cruz Biotechnology), and $\beta$-Actin (Santa Cruz Biotechnology). Membranes were washed in TBS and incubated for $1 \mathrm{~h}$ with horseradish peroxidase-conjugated secondary antibodies (Promega). Visualization was performed using enhanced chemiluminescent (ECL) detection reagent and ECL X-ray films (Amersham).

Immunoprecipitation. Cells were lysed with RIPA buffer as described above. Equal amounts of protein were processed using the ExactaCruz kit (Santa Cruz Biotechnology) following the manufacturer's protocol. Briefly, anti-Src antibody (Upstate) was mixed with immunoprecipitation matrix and incubated overnight at $4^{\circ} \mathrm{C}$. The mix was centrifuged, and cell lysates were added and incubated overnight at $4^{\circ} \mathrm{C}$ on a rotator. After centrifugation, pellets were washed in PBS, resuspended in Laemmli buffer, and boiled at $95^{\circ} \mathrm{C}$ for $5 \mathrm{~min}$. Samples were subjected to SDS-PAGE and Western blotting for Smadl/5/8 (Santa Cruz Biotechnology) and Src (Upstate).
RNA interference. Standard siCONTROL (D-001210-02), on-target plus SMART pool human Src (L-003175-00), and on-target plus SMART pool human Idl (L-005051-00) were purchased (Dharmacon). Oligonucleotides were complexed with Lipofectamine in Opti-MEM (Invitrogen) according to the manufacturer's protocol and delivered to cells at a final concentration of $100 \mathrm{nmol} / \mathrm{L}$.

Id1 promoter assays. A549 cells were transfected in 96-well plates for $24 \mathrm{~h}$ with previously described IDlpGL-luc reporter and SV40pRL coreporter plasmids at a ratio of 10:1 in the presence of Effectene (Qiagen) in $10 \%$ FBS DMEM (34). For Src inhibitor assays, cells were then incubated for $24 \mathrm{~h}$ with DMSO, PP2, or AZD0530 in 10\% FBS DMEM. Samples were lysed and analyzed using the Dual-Luciferase Reporter Assay system (Promega) on a MicroLumat luminometer (EG \& G Berthold). For Src mutant assays, cells were triple transfected for $24 \mathrm{~h}$ with ID1pGL, SV40pRL plus PCI vectors containing wild-type human Src, dominant-negative human SrcK298M (provided by Dr. Don Fujita, University of Calgary, Alberta, Canada), or constitutively active chicken SrcY527F (provided by Dr. June Zhou, University of California Davis Cancer Center, Sacramento, CA; ref. 35). Cells were then incubated in fresh 10\% FBS DMEM for $18 \mathrm{~h}$ followed by serum starvation in DMEM for $6 \mathrm{~h}$. For promoter region assays, cells were triple-transfected for $24 \mathrm{~h}$ with Src-Y527F, SV40pRL, plus fulllength ID1pGL or one of seven previously described ID1 promoter $5^{\prime}$ deletion constructs (34). Cells were then incubated in fresh 10\% FBS DMEM for $18 \mathrm{~h}$ followed by serum starvation in DMEM for $6 \mathrm{~h}$. Assays were performed in triplicates, firefly luciferase activity was normalized for Renilla luciferase activity, and relative Id 1 promoter activity was calculated based on the mean value of the respective control.

Chromatin immunoprecipitation. A549 cells were incubated with DMSO, PP2, or AZD0530 for $23 \mathrm{~h}$ followed by stimulation with BMP-2 (10 ng/mL; $1 \mathrm{~h}$ ). Cells were cross-linked with $1 \%$ formaldehyde for $10 \mathrm{~min}$ and incubated in $0.125 \mathrm{~mol} / \mathrm{L}$ glycine for $5 \mathrm{~min}$. Plates were scraped and cells were centrifuged. Pellets were resuspended in swelling buffer containing $100 \mathrm{mmol} / \mathrm{L}$ Tris, $10 \mathrm{mmol} / \mathrm{L} \mathrm{KOAc,} 15 \mathrm{mmol} / \mathrm{L} \mathrm{MgOAc}$, and protease-inhibitor cocktail (Roche); incubated for $20 \mathrm{~min}$ on ice; and dounce homogenized 15 times. Nuclei were centrifuged; resuspended in 
buffer containing $10 \mathrm{mmol} / \mathrm{L}$ EDTA, $50 \mathrm{mmol} / \mathrm{L}$ Tris- $\mathrm{HCl}$, $0.5 \%$ SDS, and protease inhibitor cocktail; and sonicated using a BioRuptor (Diagenode). Lysates were diluted in buffer containing $150 \mathrm{mmol} / \mathrm{L} \mathrm{NaCl}, 2 \mathrm{mmol} / \mathrm{L}$ EDTA, $20 \mathrm{mmol} / \mathrm{L}$ Tris-HCl, $1 \%$ Triton-X, and protease inhibitor cocktail, and split into two aliquots for overnight incubation with $5 \mu \mathrm{g}$ of antiSmad1/5/8 antibody (Santa Cruz Biotechnology) or rabbit IgG (Oncogene Science). Samples were then incubated with $5 \mu \mathrm{g}$ of sonicated salmon sperm DNA (Sigma-Aldrich) and $50 \mu \mathrm{L}$ of protein $\mathrm{G}$ agarose (Upstate) for $2 \mathrm{~h}$. After centrifugation, supernatant was stored (input control) and pellets were washed in TSE buffer [ $1 \%$ TritonX-100, 0.1\% SDS, $2 \mathrm{mmol} / \mathrm{L}$ EDTA, and $20 \mathrm{mmol} / \mathrm{L}$ Tris-HCl (pH 8.1)], eluted in TE buffer $(10 \mathrm{mmol} / \mathrm{L}$ Tris- $\mathrm{HCl}$ and $1 \mathrm{mmol} / \mathrm{L}$ EDTA), and incubated at $65^{\circ} \mathrm{C}$ overnight to reverse the cross-linking. Samples were incubated with $1 \mu \mathrm{L}$ of Proteinase $\mathrm{K}$ (Fermentas) for $1 \mathrm{~h}$ at $55^{\circ} \mathrm{C}$, and DNA was isolated using the QIAquick PCR purification kit (Qiagen). PCR for the Src-responsive region was performed using forward primer 5'-AATTGTTGGGATTACAGGCGTG- ${ }^{\prime}$ and reverse primer $5^{\prime}$-CTGGGAATGCGTTTCTTGCG-3' at an annealing temperature of $55^{\circ} \mathrm{C}$ for 35 cycles. PCR products were separated on $1.5 \%$ agarose gels.

Immunofluorescence. A549 cells in chamber slides were incubated with DMSO, PP2, or AZD0530 for $23 \mathrm{~h}$ followed by stimulation with BMP-2 (10 ng/mL; $1 \mathrm{~h})$. Cells were then fixed with $3.7 \%$ formaldehyde, permeabilized with Triton-100, blocked with $0.5 \%$ BSA in PBS, and incubated with anti-Smadl/5/8 antibody (Santa Cruz Biotechnology) overnight. Cells were washed and incubated with Alexa-647-conjugated secondary antibody and Hoechst dye. After washing, slides were analyzed using a BX61 microscope and SlideBook 4.1 imaging software (Olympus).

Establishment of a stable Id1-overexpressing A549 subline. The fulllength Idl cDNA sequence was subcloned from pBabe-IdI (26) into pLNCX2 retroviral vector (BD Clontech) for cytomegalovirus promoter-driven expression. For production of retrovirus, pLNCX2-IdI and pLNCX2-empty expression constructs $(2 \mu \mathrm{g})$ were transfected into LinX-A amphotropic packaging cells using FuGENE 6 transfection reagent. Cultures were incubated at $32^{\circ} \mathrm{C}$. After $72 \mathrm{~h}$, virus-containing supernatant was collected, centrifuged at $3,000 \times g$ for $15 \mathrm{~min}$ at $4^{\circ} \mathrm{C}$, and filtered through a $0.45-\mu \mathrm{m}$ surfactant-free cellulose acetate membrane (Corning, Inc.). A549 cells were then infected with a mix of DMEM, virus-containing supernatant (1:1), and polybrene $(4 \mu \mathrm{g} / \mathrm{mL})$. After incubation for $24 \mathrm{~h}$ at $32^{\circ} \mathrm{C}$, cells were selected in $10 \%$ FBS DMEM with $400 \mu \mathrm{g} / \mathrm{mL}$ of Geneticin (JR Scientific) at $37^{\circ} \mathrm{C}$ for $3 \mathrm{wk}$

Invasion assays. Cell culture inserts with polyethylene terephthalate membranes and $8-\mu \mathrm{m}$ pores were coated with $60 \mu \mathrm{L}$ Matrigel (BD Biosciences). Top chambers were filled with A549 cells in 5\% FBS DMEM containing siRNA, DMSO, PP2, or AZD0530. Bottom chambers were filled with $10 \%$ FBS DMEM. After $24 \mathrm{~h}$, cells in the top chamber were removed with cotton swabs, and cells on the bottom side of the insert were fixed with $3.7 \%$ formaldehyde, stained with $0.5 \%$ methylene blue, and counted on an IX50 microscope (Olympus).

Statistical analysis. All experiments were performed at least thrice; values represent the mean of triplicate samples and SEs of the mean.
Figure 3. Identification of an

Src-responsive region in the Id1 promoter. $A$, A549 cells were transfected for $24 \mathrm{~h}$ with ID1pGL firefly luciferase reporter plus SV40pRL Renilla luciferase coreporter followed by incubation for $24 \mathrm{~h}$ with DMSO, PP2, or AZD0530 at the concentrations indicated. Triplicate samples were measured using the dual luciferase reporter assay. B, A549 cells were triple-transfected with ID1pGL reporter, SV40pRL coreporter plus wild-type $(w t) \mathrm{Src}$, constitutively active (ca) Src, or dominant-negative (dn) Src. Cells were then incubated in $10 \%$ FBS DMEM for $18 \mathrm{~h}$ followed by serum starvation for $6 \mathrm{~h}$. C. A549 cells were triple-transfected for $24 \mathrm{~h}$ with constitutively active Src, and SV4OpRL coreporter plus either the ID1 full-length promoter reporter construct or one of the Id1 promoter deletion reporter constructs $\left(5^{\prime}\right.$ del- 1 to $\left.5^{\prime} \mathrm{del}-7\right)$. Cells were then incubated in $10 \%$ FBS DMEM for $18 \mathrm{~h}$ followed by serum starvation for $6 \mathrm{~h}$.

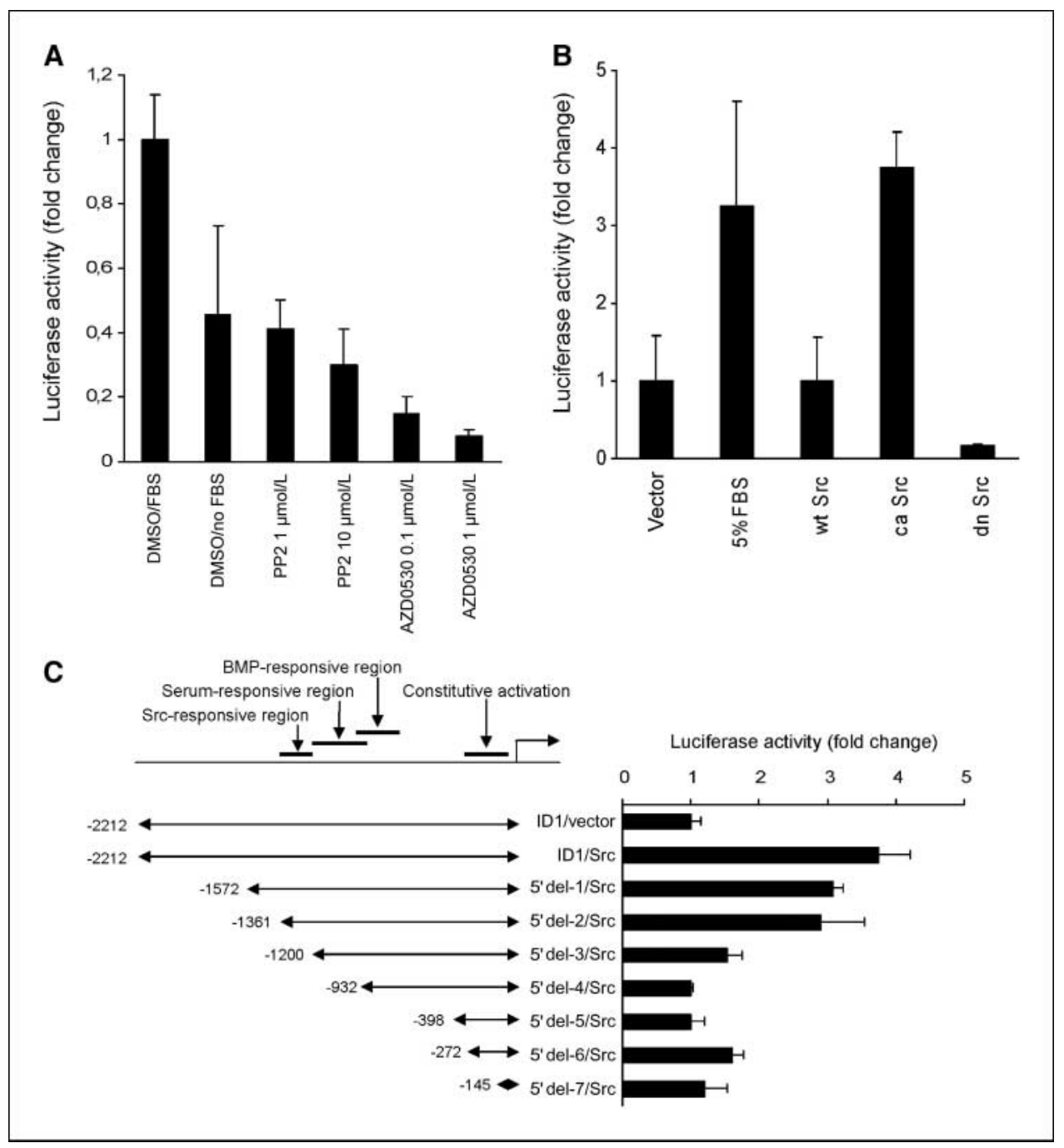




\section{Results}

Id gene expression is down-regulated by Src inhibition in cancer cells. To identify novel downstream effectors of Src signaling in cancer, we performed genome-wide expression profiling of cells subjected to Src kinase inhibition. To this end, A549 lung adenocarcinoma cells were incubated for 24 hours with AZD0530 (750 nmol/L) in DMSO or with DMSO alone followed by RNA extraction and expression analysis using Affymetrix U133 plus 2.0 arrays. A total of 175 genes were differentially regulated ( $\geq 2$-fold) in response to incubation with AZD0530. The genes most dramatically down-regulated by AZD0530 were the inhibitors of differentiation gene family members (ID1-4), inhibitory Smads (SMAD6 and SMAD7), TGFB1, and SERPINE1/PAI-1 (Supplementary Fig. S1). These findings were confirmed by standard reverse transcription PCR (RT-PCR), and the specificity of the effect of AZD0530 was shown by the fact that levels of Src and of 18S rRNA transcripts were unchanged (Supplementary Fig. S2). Taken together, these expression changes suggested that AZD0530mediated Src inhibition leads to suppression of the Smad-Id signaling pathway.

Based on its $(a)$ strong association with cancer progression and (b) well-defined regulation by Smad signaling, we chose to focus on better defining the mechanism responsible for Idl as a target of Src inhibition. To characterize further the effect of AZD0530 on Id1 mRNA levels, A549 cells were incubated with increasing concentrations of AZD0530 ( $1 \mathrm{nmol} / \mathrm{L}-10 \mu \mathrm{mol} / \mathrm{L})$ for 24 hours.
Quantitative real-time RT-PCR showed a dose-dependent reduction of Idl expression by AZD0530, which reached a nadir at $100 \mathrm{nmol} / \mathrm{L}$ (Fig. 1A). Western blot analysis of companion cultures treated with AZD0530 for 48 hours was performed to show a correlation between AZD0530-mediated Src inhibition and down-regulation of Idl. The results confirmed a dose-dependent reduction in Idl expression that corresponded with decreased levels of activated pY419-Src, whereas the levels of total Src were unchanged (Fig. $1 B$ ). The antiphospho-Src family antibody detected multiple bands between 55 and $70 \mathrm{kDa}$, consistent with the presence of multiple Src family members in A549 cells. Reprobing with Src-specific antibody confirmed that the $60-\mathrm{kDa}$ band represented the phosphorylated pp $60^{\mathrm{c}-\mathrm{Src}}$ protein.

To investigate the functional relationship between Src and Id1 and its therapeutic implications, we examined a panel of human cancer cell lines from four types of cancer, including lung (A549 and H460), breast (T47D and MDA-MB231), prostate (LNCaP and PC-3), and colon (HCT-116 and HT-29), each represented by a pair of cell lines with different invasive potential (36-39). Protein extracts of cells grown under normal conditions were subjected to Western blotting for pY419-Src, total Src, Id1, and actin (Fig. 1C). Immunoblot analysis showed that basal Src activity (pY419-Src) was easily detectable in six of eight cell lines. The levels of pY419Src corresponded with the reported invasive potential in each pair. Similarly, Id l levels corresponded with the reported invasive potential and level of pY419-Src level in six of eight cell lines.

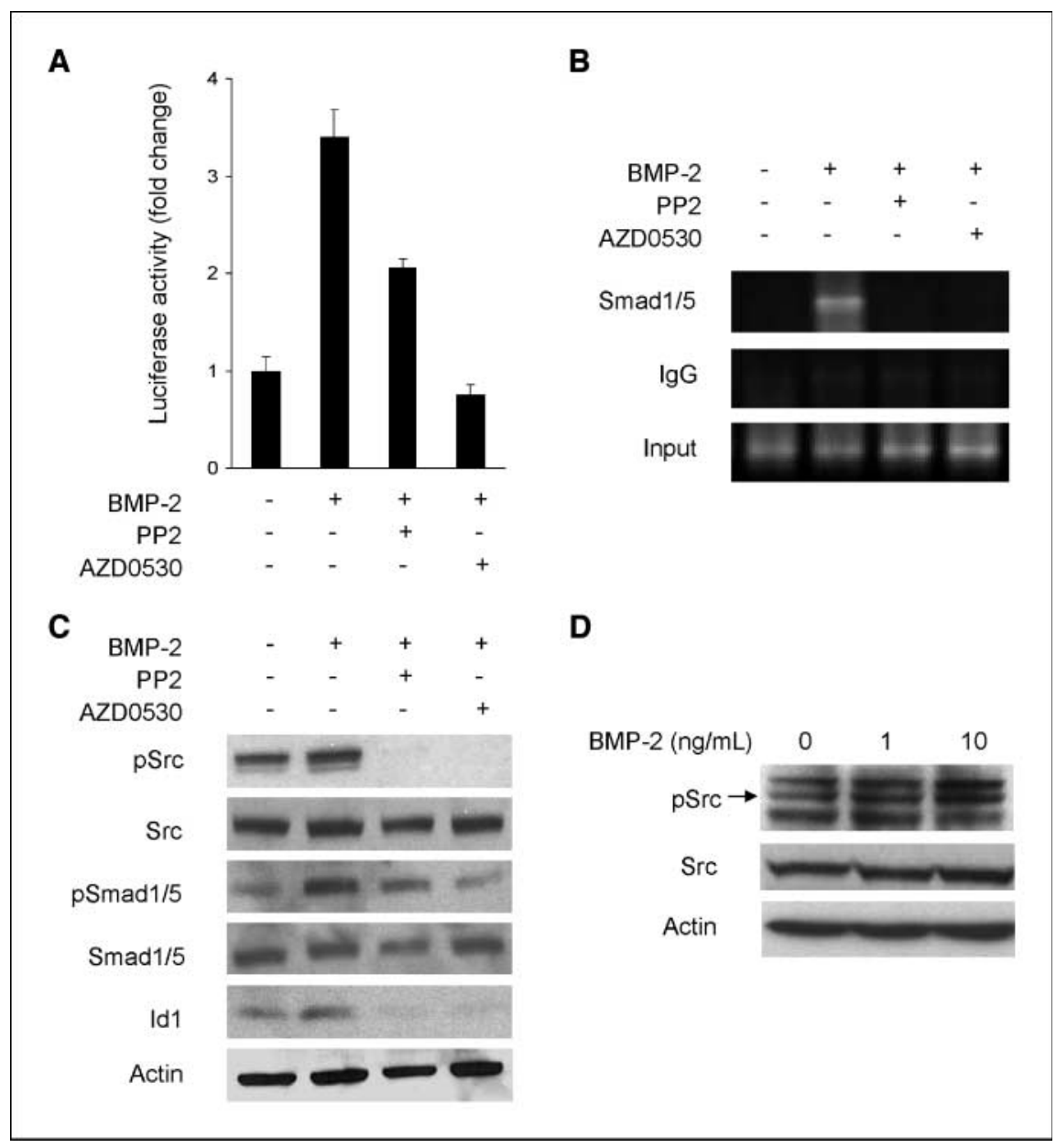

Figure 4. Cooperation of Src with the BMP/Smad signaling pathway. A, A549 cells were transfected for $24 \mathrm{~h}$ with ID1pGL reporter and SV40pRL coreporter followed by incubation with DMSO, PP2 (10 $\mu \mathrm{mol} / \mathrm{L})$, or AZD0530 $(1 \mu \mathrm{mol} / \mathrm{L})$ for $23 \mathrm{~h}$ and then stimulated with BMP-2 (10 ng/mL; $1 \mathrm{~h})$. Triplicate samples were analyzed using the dual luciferase reporter system. B, A549 cells were incubated with DMSO, PP2 $(10 \mu \mathrm{mol} / \mathrm{L})$, or AZD0530 $(1 \mu \mathrm{mol} / \mathrm{L})$ for 23 $\mathrm{h}$ followed by stimulation with BMP-2 (10 ng/mL; $1 \mathrm{~h})$. ChIP was performed using anti-Smad1/5 antibody or normal rabbit IgG. DNA was extracted and the proposed Src-responsive region of the Id1 promoter was amplified by PCR. C, A549 cells were incubated for $23 \mathrm{~h}$ with DMSO, PP2 $(10 \mu \mathrm{mol} / \mathrm{L})$, or AZD0530 $(1 \mu \mathrm{mol} / \mathrm{L})$ followed by stimulation with BMP-2 (10 ng/mL; $1 \mathrm{~h}$ ). Western blotting was performed to determine the levels of pY419-Src, Src, phospho-Smad1/5, Smad1/5, Id1, and actin. D, A549 cells were incubated for $1 \mathrm{~h}$ with BMP-2 at the concentrations indicated. Western blotting was performed to determine the levels of pY419-Src, Src, and actin. 
A

\begin{tabular}{lllll} 
BMP-2 (min) & 0 & 30 & 60 & 60 \\
AZD0530 & - & - & - & + \\
Smad1/5 & & & & \\
Src & & & & \\
\hline
\end{tabular}

Figure 5. Inhibition of Src blocks Src-Smad interaction and nuclear translocation of Smad. $A, \mathrm{H} 460$ cells were incubated with DMSO or AZD0530 $(1 \mu \mathrm{mol} / \mathrm{L})$ for $23 \mathrm{~h}$ followed by stimulation with BMP-2 $(10 \mathrm{ng} / \mathrm{mL})$ for the time periods indicated. Immunoprecipitation for Src and Western blotting for Smad1/5 and Src was performed. $B$, A549 cells in chamber slides were incubated with DMSO, PP2 $(10 \mu \mathrm{mol} / \mathrm{L})$, or AZD0530 (1 $\mu \mathrm{mol} / \mathrm{L})$ for $23 \mathrm{~h}$ followed by stimulation with BMP-2 (10 ng/mL; $1 \mathrm{~h})$. Immunofluorescent staining was performed using anti-Smad1/5/8 antibody, Alexa-647-conjugated secondary antibody, and Hoechst dye (bars, $10 \mu \mathrm{m}$ )
B

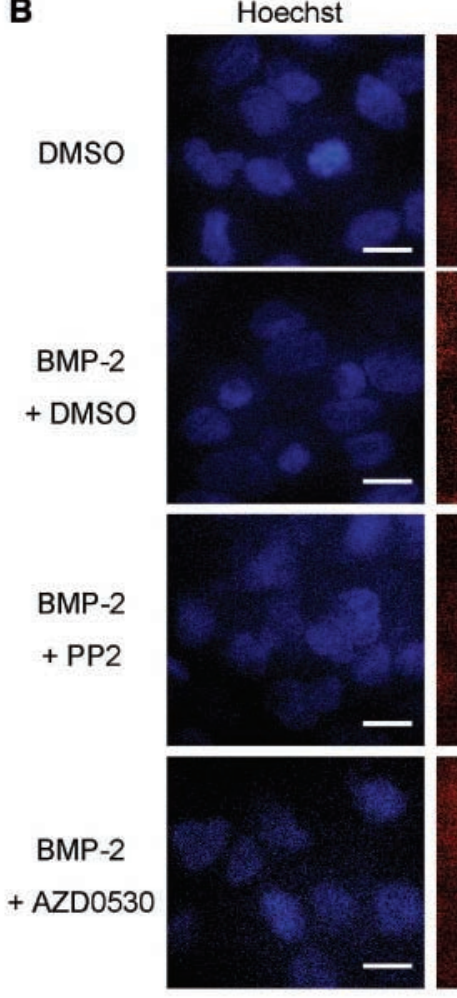

\section{Smad1/5}
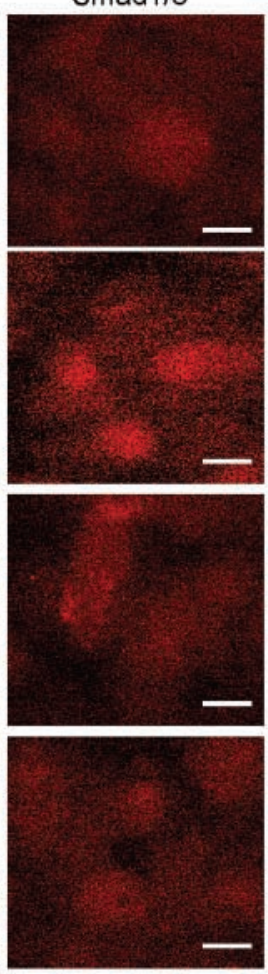
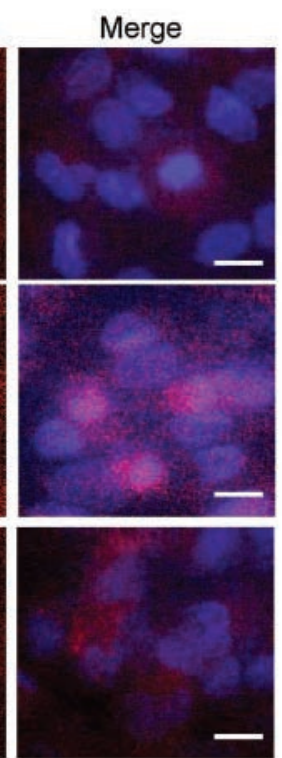

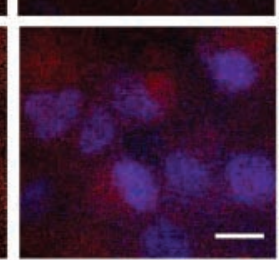

Although Id1 was highly expressed in the colon cancer cells HCT116 and HT-29, an inverse relationship between pY419-Src and Id1 levels was observed. This suggests that Src is a major regulator of Id1 but that other pathways exist to activate Id1. Next, the effect of Src inhibition on Id1 expression in each cell line was determined (Fig. $1 D)$. Incubation of the cells with PP2 $(10 \mu \mathrm{mol} / \mathrm{L})$ or AZD0530 ( $1 \mu \mathrm{mol} / \mathrm{L})$ for 48 hours reduced the levels of pY419-Src and Id1 in all cell lines. These results showed an association between Src and Idl expression, and that Src inhibitors can effectively mediate Idl down-regulation.

Reduction of Idl mRNA and protein levels by Src siRNA and blocking peptides. In addition to small-molecule inhibitors, two alternative approaches to Src-targeting were used to confirm the role of Src in the regulation of Idl expression. In the first approach, A549 cells were transfected with an Src-specific siRNA pool, as well as an Idl-specific siRNA and a nontargeting control siRNA. After 24 hours, RNA and protein was isolated and RT-PCR and Western blotting was performed, respectively (Fig. $2 A$ and $B$ ). The expected effect of each siRNA on its respective target was confirmed. Moreover, Src siRNA also reduced Idl mRNA and protein levels. The levels of 18S rRNA and actin protein remained unchanged. Src siRNA had no visual effect on other members of the Src family tested (Supplementary Fig. S3). In the second approach, A549 cells were incubated for 24 hours with cell-permeable Src-blocking peptides CpraYKYY- $\beta A l a-k 7$ and CpraYKYY- $\beta A l a-r 7$ at the concentrations indicated (Fig. $2 C$ and $D$; ref. 31). Target specificity of these peptides has been shown earlier (31). Both peptides reduced Id1 transcript levels in a dose-dependent manner. Western blotting showed a reduction in pY419-Src levels and Id1 protein levels, whereas total Src levels remained unchanged. These results confirmed that inhibition of Src activity or expression leads to reduced Id1 levels.

Identification of an Src-responsive region in the human Id1 promoter. To define further the role of Src in the regulation of Idl expression, we used dual-luciferase reporter assays to monitor the activity of the Id1 promoter. A549 cells were cotransfected with ID1pGL firefly luciferase reporter (34) and SV40pRL Renilla luciferase coreporter for 24 hours followed by incubation with DMSO, PP2, or AZD0530 for an additional 24 hours. As a control, serum starvation for 24 hours decreased the Idl promoter signal by 54\% (Fig. $3 A$ ). In comparison, both PP2 and AZD0530 significantly reduced the Idl promoter signal in a dose-dependent manner. Of note, AZD0530 $(1 \mu \mathrm{mol} / \mathrm{L})$ in serum-stimulated A549 cells reduced Idl promoter activity by $>90 \%$, suggesting that the promoter is strongly Src dependent. To investigate this further, we tested if Id1 promoter activity could be modulated by enforced expression of wild-type or mutant forms of Src. Under conditions of serumdeprivation, a constitutively active Src mutant resulted in a 3.7-fold induction in Id1 promoter activity, compared with a 3.2-fold induction by serum (Fig. $3 B$ ). In contrast, wild-type Src did not significantly alter Idl promoter activity, whereas dominantnegative Src decreased endogenous (serum deprived) Idl promoter activity by $85 \%$. In an effort to map the region in the Idl promoter that was responsible for Src-mediated activation, each of a set of $5^{\prime}$-deletion constructs $\left(5^{\prime} \mathrm{del}-1\right.$ to $\left.5^{\prime} \mathrm{del}-7\right)$ generated from the fulllength $(2.2 \mathrm{kbp})$ Idl promoter and cloned into the pGL-luciferase reporter (34) were cotransfected with SV40pRL coreporter plus constitutively active Src (Fig. $3 C$ ). Again under conditions of serum deprivation, the greatest decrease in the Idl promoter signal occurred with construct $5^{\prime} \mathrm{del}-3$ (60\% of the signal of the full-length 
promoter construct), corresponding to a region between positions 1,360 and 1,199 in the Id1 promoter. Analysis of the sequence of this newly characterized Src-responsive region revealed the CAGC motif (positions 1,352-1,349), representing a putative Smadbinding element.

Cross-talk between Src and BMP-Smad signaling pathway. BMP-2 is a well-known inducer of Idl via Smad binding to consensus elements within the Idl promoter. The findings above suggest that Src is required for Smad-mediated Idl activation. To address this, we examined the effect of Src inhibitors on BMPinduced signaling and Idl expression. In reporter assays, stimulation of A549 cells with BMP-2 $(10 \mathrm{ng} / \mathrm{mL} ; 1 \mathrm{~h})$ induced a 3.4-fold increase in Idl promoter activity above basal, serum-stimulated activity (Fig. $4 A)$. Incubation with PP2 $(10 \mu \mathrm{mol} / \mathrm{L})$ or AZD0530 ( $1 \mu \mathrm{mol} / \mathrm{L})$ reduced BMP-mediated Idl promoter activity by $40 \%$ or completely blocked the response, respectively. Chromatin immunoprecipitation (ChIP) of unstimulated and BMP-stimulated A549 cells was performed using Smad1/5 antibody followed by DNA extraction and PCR using primers spanning the newly identified Src-responsive region of the Id1 promoter (Fig. 4B). BMP-2 (10 ng/mL; 1 hour) markedly induced Smad binding to the Srcresponsive region of the Idl promoter, and this process was completely blocked in the presence of PP2 $(10 \mu \mathrm{mol} / \mathrm{L})$ or AZD0530 ( $1 \mu \mathrm{mol} / \mathrm{L})$. Consistently, BMP-induced Smad1/5 phosphorylation and Id1 expression was inhibited by PP2 and AZD0530 (Fig. 4C). This experiment also suggested Src activation by BMP-2, and indeed, a separate experiment confirmed that BMP-2 increased pY419-Src levels in a dose-dependent manner (Fig. 4D). Analysis of the blots with Scion Image software (Scion Corp.) and normalization for total Src revealed an average increase of the pY419-Src levels by $26 \%$ to $28 \%$ compared with baseline (data not shown).

To determine a physical interaction between Src and Smad, and to confirm the findings in another cell line, H460 lung cancer cells were stimulated with BMP-2 $(10 \mathrm{ng} / \mathrm{mL})$ for 30 or 60 minutes followed by immunoprecipitation of Src and Western blotting for Smad1/5 and Src (Fig. $5 A$ ). The amount of Smad1/5 present in immune complexes was increased in protein lysates from cells stimulated with BMP-2 $(10 \mathrm{ng} / \mathrm{mL} ; 1$ hour $)$, and this was blocked in the presence of AZD0530 $(1 \mu \mathrm{mol} / \mathrm{L})$. Interestingly, a small (3-5 $\mathrm{kDa})$ shift in the size of the Smad protein band occurred by stimulation with BMP-2, suggesting that phosphorylated Smad is recruited into the complex with Src. Next, the effect of Src inhibition on Smad1/5 nuclear translocation was studied. A549 cells were grown on chamber slides and incubated for 23 hours with DMSO, PP2 $(10 \mu \mathrm{mol} / \mathrm{L})$, or AZD0530 $(1 \mu \mathrm{mol} / \mathrm{L})$. Cells were then stimulated with BMP-2 (10 ng/mL; 1 hour). Immunofluorescent staining for Smadl/5 was performed and Hoechst dye used to visualize the nuclei (Fig. $5 B$ ). In unstimulated cells, Smad1/5 localization was primarily cytoplasmic. Although BMP-2 induced prominent nuclear accumulation of Smad1/5 in $\sim 30 \%$ of the cells, which was consistent with a previous report (40), PP2 and AZD0530 almost completely blocked Smad nuclear translocation. In summary, the data showed the existence of crosstalk between Src and Smad pathways, and that Src is involved in BMP-2-mediated Smad activation and nuclear translocation.

Involvement of Id1 in cancer cell invasion. The cellular consequence of the Src-Idl interaction was investigated by determining the effects of Idl modulation on the invasiveness of A549 lung carcinoma cells. First, the efficacy of different methods of Idl and Src antagonism to inhibit invasion was examined (Fig. 6A). Id1 siRNA reduced invasion by $50 \%$, whereas PP2
A

C

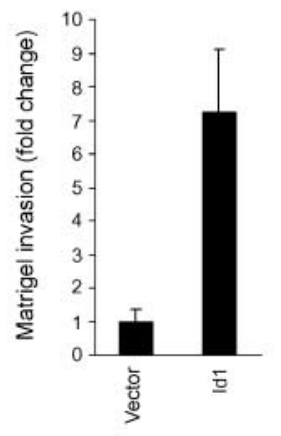

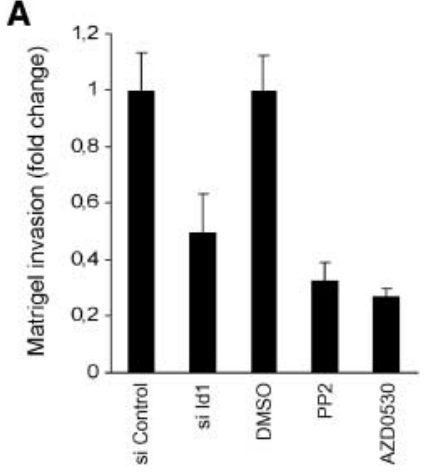

B

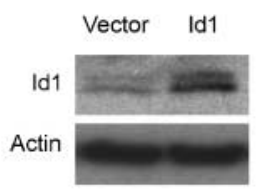

D

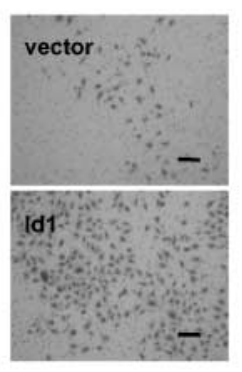

Figure 6. Involvement of Id1 in lung cancer cell invasion. $A$, Matrigel invasion assays were performed in triplicates using A549 cells incubated for $24 \mathrm{~h}$ with control si RNA, Id1 siRNA (100 nmol/L), DMSO, PP2 (10 $\mu \mathrm{mol} / \mathrm{L})$, or AZD0530 $(1 \mu \mathrm{mol} / \mathrm{L})$. After $24 \mathrm{~h}$, cells in the top chambers were removed, and cells in the bottom chambers were fixed with formaldehyde, stained with methylene blue, and counted. B, Id1 overexpressing A549 cells (Id1) and empty vector control cells (vector) were generated by retroviral infection and Geneticin selection as described under Materials and Methods. Western blotting was performed to determine the levels of Id1 and actin. Next, Matrigel invasion assays were performed in triplicates $(C$ and $D)$. After $24 \mathrm{~h}$, cells in the upper chambers were removed, and cells in the bottom chambers were fixed with formaldehyde, stained with methylene blue, and counted (bars, $50 \mu \mathrm{m}$ ).

$(10 \mu \mathrm{mol} / \mathrm{L})$ and AZD0530 $(1 \mu \mathrm{mol} / \mathrm{L})$ reduced invasion by $68 \%$ and $73 \%$, respectively. Next, the dominant role of Idl in conferring a more aggressive phenotype was tested by generating Idl-overexpressing A549 cells (A549-Id1), using retroviral gene transfer. Western blotting confirmed that Idl expression was increased markedly in A549-Id1 cells compared with empty vector control cells (Fig. 6B). Matrigel assays revealed that Idl overexpression enhanced invasion at 24 hours by 7.2 -fold compared with vector control (Fig. $6 C$ and $D$ ). These results confirmed the involvement of Idl in lung cancer cell invasion.

\section{Discussion}

The connection between BMP-2, Smad1, Id1, and cancer cell invasion is well-established. BMP-2 was found to be overexpressed in primary human lung cancer compared with normal tissue (18) and was shown to activate $\operatorname{Smad} 1 / 5$, to increase Idl expression, and to promote invasion in lung cancer cells $(40,41)$. Critical regulatory elements in the Id 1 promoter include a BMP-responsive region, a serum-responsive region, and a region associated with constitutive expression in breast cancer cells (14-16, 34). Consistent with previous data from noncancerous cells, the present 
study implicates the crosstalk of Src tyrosine kinase signaling with the BMP-Smad pathway as an additional regulator of Id1 expression in cancer (42-45). Importantly, this was also associated with a substantial diminution in invasion. This was shown by the ability of multiple methods of Src inhibition (i.e., small-molecule antagonists, peptide inhibitors, and siRNA) to markedly reduce Id1 expression and promoter activity. Conversely, transient, enforced expression of a constitutively active Src mutant induced the Idl promoter signal independently of serum or BMP-2. Using a series of Idl promoter deletion constructs, we identified a novel Srcresponsive region in the human Idl promoter. This region contains the Smad-binding motif CAGC, and we provided evidence for the binding of Smad1/5 to the Src-responsive region. Consistent with the demonstration of a functional interaction between Src and BMP-Smad1/5, and temporal association of BMP-mediated activation of Src and Smad1/5, the formation of a signaling complex of Src and Smad1/5 was shown by coimmunoprecipitation experiments. Further work is expected to reveal the molecular mechanisms by which Src is recruited to the BMP receptor complex and is activated in response to BMP signaling, and by which Src may activate Smad1/5. In this context, previous work by others showed that PP1 (and to a lesser extent, PP2) significantly inhibited TGF $\beta$ receptor kinase activity and blocked subsequent Smad2/3 signaling; this suggested the that some effects seen in our study may have resulted from direct inhibition of TGF $\beta$ receptor kinase by the small-molecule kinase inhibitors used (46). We used several different molecular approaches to Src targeting (RNA interference, small molecules, dominant-negative mutant, and inhibitory peptides) and the consistent results make it unlikely that off-target effects account for the main observations. Supporting this view, other studies showed that TGF $\beta$ did not activate, but rather inhibited, Id1 expression $(14,29,47)$. Taken together, these data suggest a model of balanced Id1 regulation in which BMP acts positively on Id 1 transcription via $\operatorname{Smad} 1 / 5$ and TGF $\beta$ acts as negative regulator via Smad2/3. Aberrant activation of Src may shift the balance toward increased Smad1/5 signaling, resulting in Idl overexpression. However, the present report also supports the existence of other undefined mechanisms of Id1 regulation because HT-29 and HCT-116 cells lacked a positive association between Src activation and Id1 expression. Because missense mutations in Smad4 exist in some colorectal cancer cells, including HT-29, Id1 expression may be driven by Smad-independent pathways in these cells (48). In this regard, the observation that Src inhibition reduced Id1 levels in MDA-MB231 cells, which constitutively express high levels of Idl in a serum-independent manner, is encouraging (34).

Our study has several clinical implications. First and most important, it points toward a new molecular mechanism of action for Src inhibitors and suggests the use of Id 1 as a biomarker. In line with this notion are gene expression signatures in breast and lung cancer, which include both Idl and Src, and which are associated with tumor aggressiveness and responsiveness to Src inhibition, respectively $(49,50)$. Second, we speculate that therapeutic strategies based on Src inhibitor-mediated Idl down-regulation may reduce tumor recurrence, angiogenesis, and metastasis. Beyond this, based on the implication of Src and BMP in osteogenesis, the findings described in the present report may lead to advances in the biology and treatment of malignant and nonmalignant bone disease.

\section{Acknowledgments}

Received 11/27/2007; revised 2/5/2008; accepted 2/8/2008.

Grant Support: The Swiss Foundation for Medical-Biological Grants/Swiss National Science Foundation (1184/PASMA-108925; O. Gautschi) and the Swiss Cancer League/Oncosuisse (BIL OCS 01949-08-2006).

The costs of publication of this article were defrayed in part by the payment of page charges. This article must therefore be hereby marked advertisement in accordance with 18 U.S.C. Section 1734 solely to indicate this fact.

We thank AstraZeneca Pharmaceuticals (Macclesfield, UK) for AZD0530, Dr. Kit Lam (University of California Davis Cancer Center, Sacramento, California) for the Srcblocking peptides, and Dr. Don J. Fujita (Department of Biochemistry and Molecular Biology, University of Calgary, Alberta, Canada) and Dr. June Zhou (UC Davis Cancer Center) for the Src expression constructs; Dr. Joy Yang (Department of Urology, UC Davis) and Ryan R. Davis (Gene Expression Resource, UC Davis Cancer Center) for the technical assistance; and the University of California Davis Cancer Center Gene Expression Resource, supported by Cancer Center Support Grant P30 CA93373-01 from the National Cancer Institute, for the microarray analysis.

\section{References}

1. Parsons SJ, Parsons JT. Src family kinases, key regulators of signal transduction. Oncogene 2004;23: 7906-9.

2. Summy JM, Gallick GE. Treatment for advanced tumors: SRC reclaims center stage. Clin Cancer Res 2006;12:1398-401.

3. Hiscox S, Morgan L, Green TP, Barrow D, Gee J, Nicholson RI. Elevated Src activity promotes cellular invasion and motility in tamoxifen resistant breast cancer cells. Breast Cancer Res Treat 2006;97:263-74.

4. Lee D, Gautschi O. Clinical development of SRC tyrosine kinase inhibitors in lung cancer. Clin Lung Cancer 2006;7:381-4.

5. Yokota Y. Id and development. Oncogene 2001;20: 8290-8.

6. Benezra R, Davis RL, Lockshon D, Turner DL, Weintraub $\mathrm{H}$. The protein Id: a negative regulator of helix-loop-helix DNA binding proteins. Cell 1990;61: 49-59.

7. Sun XH, Copeland NG, Jenkins NA, Baltimore D. Id proteins Id 1 and Id2 selectively inhibit DNA binding by one class of helix-loop-helix proteins. Mol Cell Biol 1991; 11:5603-11.

8. Lyden D, Young AZ, Zagzag D, et al. Idl and Id3 are required for neurogenesis, angiogenesis and vascularization of tumour xenografts. Nature 1999;401:670-7.
9. Desprez PY, Hara E, Bissell MJ, Campisi J. Suppression of mammary epithelial cell differentiation by the helixloop-helix protein Id-1. Mol Cell Biol 1995;15:3398-404. 10. Ying QL, Nichols J, Chambers I, Smith A. BMP induction of Id proteins suppresses differentiation and sustains embryonic stem cell self-renewal in collaboration with STAT3. Cell 2003;115:281-92.

11. Belletti B, Prisco $M$, Morrione A, Valentinis B, Navarro M, Baserga R. Regulation of Id2 gene expression by the insulin-like growth factor I receptor requires signaling by phosphatidylinositol 3-kinase. J Biol Chem 2001;276:13867-74.

12. Lasorella A, Noseda M, Beyna M, Yokota Y, Iavarone A. Id2 is a retinoblastoma protein target and mediates signalling by Myc oncoproteins. Nature 2000;407:592-8. 13. Ohtani N, Zebedee Z, Huot TJ, et al. Opposing effects of Ets and Id proteins on pl6INK4a expression during cellular senescence. Nature 2001;409:1067-70.

14. Korchynskyi $O$, ten Dijke $P$. Identification and functional characterization of distinct critically important bone morphogenetic protein-specific response elements in the Idl promoter. J Biol Chem 2002;277: 4883-91.

15. Lopez-Rovira T, Chalaux E, Massague J, Rosa JL, Ventura F. Direct binding of Smadl and Smad4 to two distinct motifs mediates bone morphogenetic proteinspecific transcriptional activation of Idl gene. J Biol Chem 2002;277:3176-85
16. Katagiri T, Imada M, Yanai T, Suda T, Takahashi N, Kamijo R. Identification of a BMP-responsive element in Idl, the gene for inhibition of myogenesis. Genes Cells 2002;7:949-60.

17. Kang Y, Chen CR, Massague J. A self-enabling TGF $\beta$ response coupled to stress signaling: Smad engages stress response factor ATF3 for Id1 repression in epithelial cells. Mol Cell 2003;11:915-26.

18. Langenfeld EM, Calvano SE, Abou-Nukta F, Lowry SF Amenta P, Langenfeld J. The mature bone morphogenetic protein- 2 is aberrantly expressed in non-small cell lung carcinomas and stimulates tumor growth of A549 cells. Carcinogenesis 2003;24:1445-54.

19. Ling MT, Lau TC, Zhou C, et al. Overexpression of Id1 in prostate cancer cells promotes angiogenesis through the activation of vascular endothelial growth factor (VEGF). Carcinogenesis 2005;26:1668-76.

20. Wilson JW, Deed RW, Inoue T, et al. Expression of Id helix-loop-helix proteins in colorectal adenocarcinoma correlates with p53 expression and mitotic index. Cancer Res 2001;61:8803-10.

21. Schindl M, Oberhuber G, Obermair A, Schoppmann SF, Karner B, Birner P. Overexpression of Id-1 protein is a marker for unfavorable prognosis in early-stage cervical cancer. Cancer Res 2001;61:5703-6.

22. Schindl M, Schoppmann SF, Strobel T, et al. Level of Id-1 protein expression correlates with poor differentiation, enhanced malignant potential, and 
more aggressive clinical behavior of epithelial ovarian tumors. Clin Cancer Res 2003;9:779-85.

23. Tournay O, Benezra R. Transcription of the dominant-negative helix-loop-helix protein Idl is regulated by a protein complex containing the immediate-early response gene Egr-1. Mol Cell Biol 1996;16:2418-30.

24. Tepper CG, Gregg JP, Shi XB, et al. Profiling of gene expression changes caused by p53 gain-of-function mutant alleles in prostate cancer cells. Prostate 2005; 65:375-89.

25. Swarbrick A, Akerfeldt MC, Lee CS, et al. Regulation of cyclin expression and cell cycle progression in breast epithelial cells by the helix-loop-helix protein Idl Oncogene 2005;24:381-9.

26. Lin CQ, Singh J, Murata K, et al. A role for Id-1 in the aggressive phenotype and steroid hormone response of human breast cancer cells. Cancer Res 2000;60:1332-40. 27. Desprez PY, Lin CQ, Thomasset N, Sympson CJ, Bissell MJ, Campisi J. A novel pathway for mammary epithelial cell invasion induced by the helix-loop-helix protein Id-1. Mol Cell Biol 1998;18:4577-88.

28. Perk J, Gil-Bazo I, Chin Y, et al. Reassessment of idl protein expression in human mammary, prostate, and bladder cancers using a monospecific rabbi monoclonal anti-idl antibody. Cancer Res 2006;66: 10870-7.

29. Tang B, Yoo $\mathrm{N}, \mathrm{Vu} \mathrm{M}$, et al. Transforming growth factor- $\beta$ can suppress tumorigenesis through effects on the putative cancer stem or early progenitor cell and committed progeny in a breast cancer xenograft model. Cancer Res 2007;67:8643-52.

30. Fong S, Itahana Y, Sumida T, et al. Id-1 as a molecular target in therapy for breast cancer cell invasion and metastasis. Proc Natl Acad Sci U S A 2003;100:13543-8. 31. Kamath JR, Liu R, Enstrom AM, Lou Q, Lam KS. Development and characterization of potent and specific peptide inhibitors of p60c-src protein tyrosine kinase using pseudosubstrate-based inhibitor design approach. J Pept Res 2003;62:260-8.

32. Li C, Wong WH. Model-based analysis of oligonucleotide arrays: expression index computation and outlie detection. Proc Natl Acad Sci U S A 2001;98:31-6.

33. Simon P. Q-Gene: processing quantitative real-time RT-PCR data. Bioinformatics 2003;19:1439-40.

34. Singh J, Murata K, Itahana Y, Desprez PY. Constitutive expression of the Id-1 promoter in human metastatic breast cancer cells is linked with the loss of $\mathrm{NF}-1 / \mathrm{Rb} / \mathrm{HDAC}-1$ transcription repressor complex. Oncogene 2002;21:1812-22.

35. Tanaka A, Fujita DJ. Expression of a molecularly cloned human c-src oncogene by using a replicationcompetent retroviral vector. Mol Cell Biol 1986;6:3900-9.

36. Navab R, Gonzalez-Santos JM, Johnston MR, et al. Expression of chicken ovalbumin upstream promoter transcription factor II enhances invasiveness of human lung carcinoma cells. Cancer Res 2004;64:5097-105.

37. Irby RB, Malek RL, Bloom G, et al. Iterative microarray and RNA interference-based interrogation of the SRC-induced invasive phenotype. Cancer Res 2005;65: 1814-21.

38. Chuan YC, Pang ST, Cedazo-Minguez A, Norstedt G, Pousette A, Flores-Morales A. Androgen induction of prostate cancer cell invasion is mediated by ezrin. J Biol Chem 2006;281:29938-48.

39. Gordon LA, Mulligan KT, Maxwell-Jones H, Adams M, Walker RA, Jones JL. Breast cell invasive potential relates to the myoepithelial phenotype. Int J Cancer 2003;106:8-16. 40. Langenfeld EM, Kong Y, Langenfeld J. Bone morphogenetic protein 2 stimulation of tumor growth involve the activation of Smad-1/5. Oncogene 2006;25:685-92. 41. Langenfeld EM, Kong Y, Langenfeld J. Bone morphogenetic protein-2-induced transformation involves the activation of mammalian target of rapamycin. Mol Cancer Res 2005;3:679-84.
42. Wong WK, Knowles JA, Morse JH. Bone morphogenetic protein receptor type II C-terminus interacts with c-Src: implication for a role in pulmonary arterial hypertension. Am J Respir Cell Mol Biol 2005;33:438-46.

43. Mima A, Matsubara T, Arai H, et al. Angiotensin IIdependent Src and Smadl signaling pathway is crucial for the development of diabetic nephropathy. Lab Invest 2006;86:927-39.

44. Kersten C, Dosen G, Myklebust JH, et al. BMP-6 inhibits human bone marrow B lymphopoiesis-upregulation of Idl and Id3. Exp Hematol 2006;34:72-81.

45. Hagen M, Fagan K, Steudel W, et al. Interaction of interleukin-6 and the BMP pathway in pulmonary smooth muscle. Am J Physiol Lung Cell Mol Physio 2007;292:L1473-9.

46. Maeda M, Shintani Y, Wheelock MJ, Johnson KR. Src activation is not necessary for transforming growth factor (TGF)- $\beta$-mediated epithelial to mesenchymal transitions (EMT) in mammary epithelial cells. PP1 directly inhibits TGF- $\beta$ receptors I and II. J Biol Chem 2006;281:59-68.

47. Murillo MM, del Castillo G, Sanchez A, Fernandez M, Fabregat I. Involvement of EGF receptor and c-Src in the survival signals induced by TGF- $\beta 1$ in hepatocytes. Oncogene 2005;24:4580-7.

48. Woodford-Richens KL, Rowan AJ, Gorman P, et al SMAD4 mutations in colorectal cancer probably occur before chromosomal instability, but after divergence of the microsatellite instability pathway. Proc Natl Acad Sci U S A 2001;98:9719-23.

49. Minn AJ, Gupta GP, Padua D, et al. Lung metastasis genes couple breast tumor size and metastatic spread Proc Natl Acad Sci U S A 2007;104:6740-5.

50. Bild AH, Yao G, Chang JT, et al. Oncogenic pathway signatures in human cancers as a guide to targeted therapies. Nature 2006;439:353-7. 


\title{
A novel neuropeptide-autocrine model for androgen-insensitive prostate
}

\author{
cancer: aberrant activation of androgen receptor and \\ inhibition by AZD0530 ${ }^{1}$
}

Joy C. Yang, Joon-ha Ok, J. Erik Busby, Alexander D. Borowsky, Hsing-Jien Kung, and Christopher P. Evans ${ }^{2}$.

Departments of Urology (J.C.Y., J.-h.O., J.E.B., and C.P.E.) Biological Chemistry (H.-J.K.) and Cancer Center (H.-J.K., C.P.E.), University of California at Davis, Sacramento, CA 95817, and Center for Comparative Medicine, University of California, Davis, CA 95616 (A.D.B.)

${ }^{1}$ Supported by NIH Grants KO8 DK60748-01, 2RO1 DK/AG52659- 04, and Department of Defense PC10520. Mention of trade name, proprietary product or specific equipment does not constitute a guaranty of warranty by the Department of Defense, nor does it imply approval to the exclusion of other products. The views expressed herein represent those of the authors and do not necessarily represent the position of Department of Defense.

${ }^{2}$ To whom requests of reprints should be addressed, at the Department of Urology, University of California, Davis School of Medicine, 4860 Y St., Suite 3500, Sacramento, CA 95817.

Key words: GPCR, neuroendocrine, neuropeptides, androgen-independence, Src kinase, prostate cancer 


\section{ABSTRACT}

Neuroendocrine differentiation of $\mathrm{CaP}$ cells is often detected under androgen-deprived conditions. Neuropeptides released by these neuroendocrine-differentiated CaP cells may facilitate the development of androgen independence. Exemplified by GRP (gastrin-releasing peptide), these neuropeptides transmit their signals through G-protein coupled receptor (GPCRs), which are often overexpressed in prostate cancer. We developed an autocrine neuropeptide model by overexpressing GRP in LNCaP cells to attain their androgen-independence. LNCaPGRP cells were evaluated for proliferation, migration and tumorigenesis in androgen-free environments in vitro and in vivo. LNCaP-GRP cells orthotopically implanted in castrated nude mice produced significant tumors, with expression of GRP, prostate-specific antigen, and androgen receptor nuclear localization. Chromatin immunoprecipitation studies of LNCaP-GRP clones suggest that expressed GRP signals, activates and recruits AR to the cognate promoter in the absence of androgen. Recultured LNCaP-GRP xenografts (GRP-Pro cells) showed enhanced androgen independent growth and motility. A Src family kinase (SFK) inhibitor, AZD0530 inhibits not only androgen-independent growth and migration but also AR nuclear translocation of the GRP and GRP-Pro cell lines, demonstrating its potential in the treatment of hormone refractory CaP. In vivo study showed AZD0530 profoundly inhibits tumor metastasis in severe combined immunodeficient (SCID) mice implanted with GRP-Pro cells. This xenograft model demonstrates autocrine, neuropeptide- and Src kinase-mediated progression of androgenindependent $\mathrm{CaP}$ post-castration, and is potentially useful for testing novel therapeutic agents.

\section{INTRODUCTION}

Prostate cancer is the most frequently diagnosed cancer in American men and the second leading cause of cancer deaths (1). Androgen withdrawal initially induces apoptosis and cell 
cycle arrest in $\mathrm{CaP}$; however, $\mathrm{CaP}$ eventually loses its dependence on androgens and progresses to an androgen-independent state. Various mechanisms have been postulated to account for the conversion of $\mathrm{CaP}$ into hormone-refractory state, including the aberrant activation of androgen receptor by peptide growth factors and ligands for GPCRs (2-4). If true, these mediators and components of their signal pathways are potential targets for therapeutic intervention of hormone-refractory $\mathrm{CaP}$. It has been reported that androgen withdrawal from androgendependent $\mathrm{CaP}$ cells (5) or treatment with stimuli such as IL-6 and forskolin in vitro promotes acquisition of the neuroendocrine phenotype through transdifferentiation (6). Cumulative evidence suggests that neuroendocrine differentiation of $\mathrm{CaP}$ may be a cofactor involved in tumor progression and androgen independence (7).

Neuroendocrine cells are identified by their neurosecretory granules and expression of neuron specific markers including chromogranin $\mathrm{A}$, neuron-specific enolase and mitogenic neuropeptides such as bombesin/GRP, somatostatin, calcitonin, and parathyroid hormone-related peptides (7). Neuropeptides have been identified as potent paracrine and autocrine growth factors in human cancers to include lung, gastrointestinal, pancreatic, brain, and prostate (8-13). In prostate cancer, previous studies by others and by us have shown that neuropeptides promote cell growth (14), migration and protease expression (15) in PC-3 cells, and androgenindependence in $\mathrm{LNCaP}$ cells $(3,5)$. Androgen independence in $\mathrm{CaP}$ patients is shown to correlate well with elevated serum levels of chromogranin A (16). Elevated expression of GRP receptors are often detected in $\mathrm{CaP}$ specimens $(17,18)$.

The bombesin/GRP family is among the most studied neuropeptide group in CaP. Bombesin/GRP transduces signals by engaging heterotrimeric $\mathrm{G}$ protein-coupled receptors located on the cell surface (19). Upon binding to its receptors, bombesin/GRP elicits calcium mobilization in PC-3 and DU 145 cells $(20,21)$ and promotes growth and cell invasiveness via 
proteolytic activities of MMP's in LNCaP and PC-3 cells (15). We have previously shown that exogenous bombesin/GRP activates $\mathrm{AR}$ and supports androgen-independent growth in LNCaP through signaling mediated by non-receptor tyrosine kinases such as Src, FAK and Etk (3). In vivo androgen withdrawal following establishment of LNCaP tumors results in increased neuroendocrine cells (5). Together, these data suggest that castration induced neuroendocrine differentiation may release soluble factors, which sustain the growth and survival of androgendeprived cells, contributing to tumor androgen-independence and metastasis.

In this paper, we describe a neuropeptide xenograft model and use it to test inhibition of the tyrosine kinase pathway implicated in the development of androgen-independence. We introduced the GRP-expressing vector into LNCaP cells to establish an autocrine neuroendocrine model. The GRP clones exhibited enhanced proliferation and migration properties under androgen-depleted conditions, and developed significant tumors in castrated nude mice, providing evidence for GRP's role in androgen-independent growth through modulation of AR. We tested the effect of a SFK inhibitor AZD0530 on recultured xenograft cells both in vitro and in vivo. Our results showed that AZD0530 effectively blocked the androgen-independent growth and migration of LNCaP cells mediated by autocrine GRP, through inhibiting activation of the Src/FAK/Etk complex. SCID mice implanted with GRP-autocrine LNCaP cells and treated with AZD0530 showed a complete inhibition of tumor metastasis.

\section{MATERIALS AND METHODS}

Cell culture. LNCaP cells (ATCC, passages 38-43) were kept in RPMI1640 with 10\% regular FBS. When stimulated, cells were switched to phenol-red free RPMI1640 with 5\% charcoal-stripped androgen-free (CS) serum. 
Proliferation assays. Cells were grown in CS medium alone or with supplemented with $100 \mathrm{nM}$ of bombesin, with $1 \mu \mathrm{g} / \mathrm{ml}$ of bombesin/GRP specific monoclonal antibody $2 \mathrm{~A} 11$ (22), 5 $\mu \mathrm{M}$ of GRP receptor antagonist RC3095 (23) or transfection of $100 \mu \mathrm{M}$ of small inhibitory RNA (siRNA, sense sequence GGAAACAGUUCAACACUCAUU, validated by RT-PCR for inhibition, Dharmacon) for GRP receptor. Cells were tryspinized and counted by trypan blue exclusion method after 48 hours or over 6 days for siSrc transfection.

Chemotaxis migration assay. Migration assays were performed in a Boyden chamber with $8 \mu \mathrm{m}$ Nucleopore membrane coated with human plasma fibronectin $(50 \mu \mathrm{g} / \mathrm{ml}) .2 \times 10^{4}$ LNCaP cells were placed in the upper wells with testing agents in the lower wells, and incubated at $37^{\circ} \mathrm{C}$ for 4 hours to allow cell migration. At the end of incubation, the membrane was stained by Diff-Quik Stain Kit and mounted on microscopic slides for counting. Each experiment was performed in triplicate. AZD0530 (500 nM) or siSrc transfection was used for inhibitor studies.

GRP-expressing construct and transfection. GRP cDNA was amplified from the small cell lung carcinoma DMS53 cell line (ATCC), which expresses GRP. The amplified cDNA was inserted into mammalian expression vector pcDNA3.1-Zeocin (Invitrogen). LNCaP cells were transfected with this GRP construct or the empty vector and stable transfectants were selected with Zeocin $(100 \mu \mathrm{g} / \mathrm{ml})$ as GRP or Zeo (the mock transfectant). Presence of the GRP gene in selected clones was confirmed by Northern blotting and RT-PCR.

Quantitation of secreted GRP. CM collected from LNCaP, LNCaP-zeo, GRP1-1, GRP4-9 and DMS53 cells was concentrated by passing through PrepSep C18 reverse columns (Fisher) and the retainee was eluted with acetonitrile:water:acetic acid (59:40:1) mixture (24). The reconstituted solvent-free eluents were assayed for bombesin/GRP with a Bombesin EIA kit (Peninsula Lab). 
Soft Agar Assay. $2 \times 10^{4}$ cells were plated in the midst of $0.3 \%$ agar in CS medium with or without $2 \mathrm{~A} 11(1 \mu \mathrm{g} / \mathrm{ml})$. Colony formation was examined after 4 weeks. For the recultured GRP xenograft bicalutamide $(5 \mu \mathrm{M})$ was used additionally.

In vivo tumor biology. Animal studies were conducted in accordance with institutional ethical guidelines for the care and use of experimental animals. Surgical castration was performed and immediately following castration, $2 \times 10^{6} \mathrm{LNCaP}-\mathrm{Zeo}$ and GRP cells cosuspended with $30 \%$ matrigel were injected orthotopically into twenty and twelve castrated nude mice, respectively. At the end of 4 months, mice were sacrificed and their prostates were collected for pathological analyses. Tumor sections were immunohistochemically stained with antibodies for GRP (RGG7130, Peninsula Laboratories), AR (PG21, Millipore) and PSA (ERPR8, Dako) and detected using the DAKO Envision+ Kit. PSA levels were determined by the Micro PSA ELISA kit (Fitzgerald Industries).

Tumors were dissociated into singe-cell suspensions with collagenase and plated in CS media. The derived LNCaP GRP sublines termed GRP-Pro (derived from Prostate) were pooled together and subjected to soft agar assay to examine their androgen-independent and tumorigenic characteristics.

For inhibitor study, fourteen castrated SCID mice were orthotopically implanted with $4 \times 10^{6}$ re-cultured GRP-Pro cells. SCID mice were used to better study tumor metastasis. Two weeks after surgery, mice are divided into two groups, with 7 treated with $50 \mathrm{mg} / \mathrm{kg} /$ day via esophageal gavaging (AZD0530-treated) and 7 with buffer only (control). The study was terminated when one of the control mice succumbed to tumor burden. All the mice were euthanized, their primary tumors excised for weighing and IHC staining with p-Src (Cell Signaling), p-FAK (ABR) or AR antibodies and lymph nodes examined for metastasis. 
Transient transfection assays. Zeo, GRP4-9 and GRP Pro cells were seeded in 24-well plates, transfected with $0.2 \mu \mathrm{g}$ of PSA-Luc (promoter region, $630 \mathrm{bp}$ ) with the internal control pTK-RL using Effectene ${ }^{\circledR}$ (Qiagen). Transactivation was examined by the dual-luciferase assay (Promega). For RNA interference, standard siCONTROL (D-001210-02, SC) and on-target plus SMART pool human Src (L-003175-00, SiSrc, Dharmacon) were complexed with Lipofectamine 2000 (Invitrogen) and delivered to cells grown in CS media at a final concentration of $100 \mathrm{nM}$.

Chromatin Immunoprecipitation. LNCaP-Zeo, GRP, and GRP-Pro cells grown to subconfluency were switched to CS media for 3 days. Treatment with R1881 was performed 6 hours before harvesting. Chromatin immunoprecipitation was performed as described $(4,25,26)$ with $6 \mu \mathrm{g}$ of anti-AR antibody (PG-21, Millipore). Standard PCR cycling protocol was performed with $58^{\circ} \mathrm{C}$ for annealing for 30 cycles. Primers for AR enhancer region are: 5'catgttcacattagtacaccttg3' and 5'tctcagatccaggcttgcttac3'; for proximal ARE region: 5'tcctgagtgctggtgtcttag3' and 5'agccctataaaaccttcattcc3'; and for intervening region: 5'tcatccactcatcatccagcatc3' and 5'ggagagcaatagacttgggaaacc3'.

Immunofluorescent staining of AR. Cells $(2,500)$ were plated in 4-well chamber slides in CS media a day before fixing with 2\% paraformaldehyde for staining. Anti-AR (N-20, Santa Cruz) and anti-rabbit Alexa Fluor 647 (Invitrogen) were used as the primary and secondary antibodies for staining, respectively. Immunofluorescent cells were visualized using an Olympus BX61 motorized reflected fluorescence microscope system with an AMCA filter for DAPI and a Cy5 filter for Alexa Fluor647 using the SlideBook4.1 software (Intelligent Imaging Innovations).

Immunoprecipitation and Western blot. LNCaP-Zeo, GRP and GRP-Pro cells were subjected to androgen withdrawal for 3 days with or without exposure to AZD0530 (1 $\mu \mathrm{M})$. Cell lysates were collected in IP buffer containing proteinase and phosphatase inhibitors, incubated with anti-FAK and subsequently protein $\mathrm{G}$ agarose beads for immunoprecipitation. 
Phosphorylation of the respective precipitated proteins was detected by anti-p-Src family (Cell Signaling), p-FAK (Invitrogen) and p-Etk (Cell Signaling) antibodies after Western blotting analysis. Signals were detected by ECL system (Amersham) followed by exposure to X-ray film.

Statistics. All in vitro data were from at least three independent experiments and subjected to paired t-tests using Statview program.

\section{RESULTS}

It has been shown that bombesin confers androgen-independent growth of LNCaP cells (3). We validated that bombesin signals through the GRP receptor with specific inhibitors such as bombesin/GRP specific monoclonal antibody 2A11 and GRP receptor antagonist RC3940-II. Bombesin also stimulated cell migration as compared to the negative control (supplementary data \#1).

\section{Expression of GRP enhances proliferation and migration of transfected LNCaP}

cells. We established an autocrine model by introducing a GRP overexpressing vector to androgen-sensitive LNCaP cells to study the signaling pathways involved in androgen independence in vitro and in vivo. Stable LNCaP-GRP transfectants were established by overexpressing GRP cDNA and screened by Northern blotting and RT-PCR (Figure 1A). Positive clones (e.g. GRP1-1 and GRP4-9) were isolated and characterized. Bombesin/GRP enzyme immunoassay performed on CM collected from parental LNCaP, the vector-transfected control LNCaP-zeo, GRP1-1 and 4-9, as well as the GRP expressing DMS53 cells confirmed GRP expression in the two GRP clones (Figure 1B). GRP1-1 and 4-9 cells produce almost 5 fold more GRP than the control lines, but comparable to DMS53 cells. Antibody 2A11, GRP receptor antagonist RC3905 and siRNA for the GRP receptor effectively inhibited the androgen- 
independent growth of GRP1-1 and 4-9 to $20-60 \%$ of the control (Figure 1C). Negative control using siRNA targeting green fluorescence protein showed no effect on growth (data not shown). These data support the notion that GRP/bombesin is able to confer androgen-independent growth of $\mathrm{LNCaP}$ through binding to its membrane receptor. If the androgen independent growth is due to the autocrine release of GRP into the media, we would expect a chemotactic effect from GRP CM. As expected, LNCaP-Zeo migration was stimulated by bombesin (Figure 1D). GRP CM stimulated LNCaP-Zeo migration by more than 3 -fold and this migration was significantly reduced by 2A11 ( $p \leq 0.001)$, suggesting GRP's involvement. Migration of GRP1-1 and 4-9 towards ctlCM was two-fold greater than that of LNCaP-zeo, and could be further stimulated by GRP CM, and significantly inhibited by $2 \mathrm{~A} 11(p \leq 0.001)$. These data showed that LNCaP-GRP cells release GRP, which confers androgen-independent growth and migration on themselves through autocrine loop as well as on the control LNCaP-Zeo cells.

\section{GRP promotes in vitro and in vivo tumorigenesis in androgen-free environments.}

Soft agar assay was performed to assess in vitro tumorigenicity. GRP1-1 and 4-9 produced significantly more colonies than LNCaP-Zeo in CS medium, suggesting that the autocrine GRP induces both androgen- and anchorage-independent growth (Figure 2A). 2A11 significantly inhibited colony formation of both GRP1-1 and 4-9 ( $p \leq 0.05$ and $p \leq 0.0005)$. We then used the GRP clones for in vivo tumor study. Orthotopic prostatic implantation of GRP4-9 cells into prostates of castrated nude mice resulted in tumor growth in 8 of 12 mice. In contrast, 0 of 20 castrated mice implanted with LNCaP-zeo cells displayed any tumor growth. To generalize this finding, GRP1-1 was also orthotopically implanted and 4 of 5 mice produced tumors. $\mathrm{H}$ and $\mathrm{E}$ staining of the tumors showed characteristic human $\mathrm{CaP}$ tumors adjacent to normal mouse prostate tissue (Figure 2B). IHC staining (Figure 2C) showed staining of GRP ( $a$ and $b$ ) was evident throughout the cytoplasm of the tumor regions, yet minimally detected in the normal 
mouse prostate epithelium of the tumor, despite the fact that the GRP antibody used reacts with both human and mouse GRP. Staining with anti- AR antibody ( $c$ and $d$ ) demonstrated its nuclear translocalization in tumor cells, indicative of GRP ligand activation. PSA expression $(e$ and $f)$ was extensive in the tumor specimens, again supporting GRP-mediated AR activation. Mean serum PSA level in castrated LNCaP-GRP tumor mice was $208.9 \pm 24.6 \mathrm{ng} / \mathrm{ml}$ serum, as compared to $6.13 \times 10^{-5} \mathrm{ng} / \mathrm{ml}$ in castrated LNCaP-zeo mice.

Tumors harvested from GRP implanted mice were re-cultured in vitro to establish a xenograft cell line, labeled GRP-Pro. Expression of PSA, AR and GRP in GRP-Pro cells was analyzed by RT-PCR analysis for the authenticity of the clones (supplementary data \#2). RTPCR for the endogenous PSA mRNA for all clones is shown in the supplementary data. Soft agar assay using GRP-Pro cells showed their aggressive nature as manifested by their androgenand anchorage- independent growth in 2 weeks (Figure 3A). This growth was partially inhibited by $2 \mathrm{~A} 11$ and the androgen inhibitor, bicalutamide, individually or in combination (with significant difference $p \leq 0.05$ ) suggesting that growth is dependent on both GRP and AR.

GRP modulates activation of the androgen receptor. We further sought to illustrate GRP-mediated AR activation at the molecular level. Transactivation assay was performed with LNCaP-Zeo, GRP-4-9 and GRP-Pro cells in CS media using promoter PSA-Luc as the reporter. Expression of PSA-Luc in GRP4-9 and GRP-Pro is 1.8 and 4.5 fold higher than in LNCaP-Zeo cells (Figure 3B). This suggests GRP secreted from GRP cells is driving the expression. Addition of synthetic androgen R1881 induced PSA-Luc expression in LNCaP-Zeo cells more than 6 fold, but much less in GRP4-9 and GRP-Pro cells probably because the GRP-activated AR, through post-translational modification, already adopted an active conformation and may not be further stimulated by R1881. If GRP activates AR in GRP-Pro cells, AR should be recruited to ARE sites in the PSA promoter. We therefore performed the ChIP assay on LNCaP- 
Zeo, GRP4-9 and GRP-Pro cells in CS or CS+R1881 conditions. AR binding was analyzed by PCR using respective primers against enhancer (E) and proximal (P) ARE regions, and an intervening (I) region void of any ARE sites. Figure 3C shows AR binds to PSA P region in GRP4-9 and GRP-Pro even in the absence of androgen. When treated with R1881, AR binds preferentially to the E site in LNCaP-Zeo; whereas in GRP4-9 and GRP-Pro, AR binding was evenly detected at both $\mathrm{P}$ and $\mathrm{E}$ sites.

\section{Src and FAK tyrosine kinases play important roles in GRP-mediated androgen-} independent growth and migration. Exogenous bombesin induces AR nuclear translocation, and this induction is inhibited by Src inhibitor PP2 (25). In our LNCaP GRP mouse model, AR is localized to the nuclei as shown in the tumor IHC staining (Figure 2C). We further compared the GRP cells with the mock control by immunofluorescent staining to confirm AR nuclear localization in GRP cells through autocrine GRP-mediated activation (Figure 4). Staining of AR is limited to the cytoplasm in Zeo cells grown in CS media but concentrated to the nuclei of GRP cells (counted $65 \%$ nuclei with AR). This localization was inhibited by AZD0530, a selective SFK inhibitor demonstrating significant effects on prostate cancer cells (27). Almost half of GRP cells (35\% nuclei with AR remaining) lost nuclear staining of AR when Src activity is inhibited. These data confirm that GRP activates AR through Src and promotes its nuclear translocation, consistent with recent data that Src directly phosphorylates AR at Y534 resulting in nuclear translocation (28).

Among all the tyrosine kinases expressed in LNCaP cells, we previously showed that Src and FAK are most prominently activated by bombesin (3). Activated Src and FAK engage Etk, a tyrosine kinase shown to be involved in prostate carcinogenesis $(3,29)$. Src and FAK form a complex through binding between the phosphorylated Y397 in FAK and the SH2 domain in Src (30), whereas FAK associates with Etk via the FERM domain of FAK and the PH domain of Etk 
(31). These three kinases cross activate one another with increased tyrosine phosphorylation of the complex. Using AZD0530, we examined whether the androgen-independent growth and migration stimulation observed in our autocrine model is mediated through the Src/FAK signaling pathway. In LNCaP cells, in addition to Src, another member of SFK, Lyn, is also significantly expressed. We thus examined the phosphorylation status of Src, Lyn and FAK kinases in all cell lines grown in CS medium. We immunoprecipitated Src and Lyn proteins with their respective antibodies, then probed with anti-p-Src or anti-p-Y antibodies. For FAK, we used anti-p-FAKY861, residue phosphorylated by Src, which is another indicator of the activity of SFKs. All the GRP and GRP-Pro lines displayed higher levels of kinase phosphorylations compared to Zeo cells after exposure to CS serum for 3 days and the phosphorylations were inhibited by AZD0530 (Figure 5A). The data showed that 1) autocrineGRP indeed activates the SFKs; and 2) AZD0530, a pan-Src inhibitor, effectively blocks the activity of Src family members. Thus, while in the ensuing studies we will focus on the molecular characterizations of Src, the biological effects observed are likely due to the combined inhibition of all SFKs expressed in LNCaP cells. We previously reported that when activated, Src forms a complex with FAK and Etk and these kinases cross activate one another. Coimmunoprecipitation of Src, FAK and Etk kinases with the anti-FAK antibody confirms the complex formation and showed elevated activation of the three kinases in GRP and GRP-Pro cells compared to Zeo cells. Treatment with AZD0530 significantly reduced the degree of tyrosine phosphorylation of all three kinases but to a much less extent, the association between FAK and Src. (Figure 5A).

Regarding proliferation, AZD0530 reduced GRP-Pro cell growth in a dose-dependent manner and inhibited the anchorage- and androgen-free growth of GRP-Pro cells (supplementary data \#3). To ensure AZD0530 targets Src through which GRP mediates AR activation, RNA 
interference experiment for Src (siSrc) was performed. Transfection of siSrc into GRP4-9 and GRP-Pro cells greatly impaired their ability to grow in CS media compared to their respective non-target controls (SC, scramble RNA); whereas the LNCaP-Zeo cells do not grow well in the androgen-deprived condition with or without siSrc (Figure 5B). These data support that Src is a major target in neuropeptide-mediated AR activation, possibly through it downstream kinases such as FAK and Etk. Both FAK and Etk function in cell adhesion and migration, and inhibition of Src would reduce LNCaP-GRP and GRP-Pro cell migration. As a result, motility of GRP4-9 $(p \leq 0.05)$ and GRP-Pro $(p \leq 0.0005)$ cells was significantly inhibited by AZD0530 $(500 \mathrm{nM})$ (Figure 5C). Knocking down Src with siSrc transfection into GRP4-9 and GRP-Pro cells also reduced cell migration to the comparable level as Zeo cells. These data support the notion that the GRP-mediated androgen-independent growth and migration is principally through SFK, especially Src kinase.

SFK inhibitor AZD0530 prevents tumor metastasis in SCID mice. With the encouraging results of AZD0530 inhibition in vitro, we evaluated it in our orthotopic GRP mouse model. Fourteen castrated SCID mice implanted with GRP-Pro cells; half of them were administered $50 \mathrm{mg} / \mathrm{kg} / \mathrm{day}$ of AZD0530 (treatment) beginning two weeks after surgery (to permit tumor establishment) and half with buffer only (control) for eight weeks. All control animals grew tumor with lymph node metastasis (Figure 6A). H \& E staining (insert) of the lymph node validated its human prostate cancer origin. Five of seven treated animals produced primary tumors, but none had metastasis. IHC staining using anti-p-Src and anti-p-FAK antibodies showed reduced phosphorylation levels in the treatment samples (Figure 6B) confirming the effect of AZD0530 in tumors. When probed with anti-AR antibody, the control tumor showed AR nuclear localization as in Figure 2C. AR staining became undetectable in AZD0530 treated tumor since castrated animals were used. As a result, PSA levels from sera of 
AZD0530 treated mice showed significant reduction $(p=0.02)$ compared to controls (Figure 6C).

Primary tumor sizes in the treated animals were smaller, although not statistically significant $(p=0.104)$ when compared to control animals. AZD0530 however completely blocks tumor metastasis possibly through inhibiting SFK and FAK.

\section{DISCUSSION}

In this study, we report the development of a neuropeptide-autocrine model for androgeninsensitive $\mathrm{CaP}$. This model was not designed to study neuroendocrine tumors of prostate, which are relatively rare, but to study the effect of neuropeptides released from neuroendocrine prostate cells on $\mathrm{CaP}$ progression following androgen ablation. There is abundant literature documenting the correlation of increased number of post-mitotic neuroendocrine cells with the development of castration-resistant $\mathrm{CaP}$ and reports showing overexpression of neuropeptides and neuropeptide receptors in advanced $\mathrm{CaP}$ (16-18). Yet, the biological effect of neuropeptides on $\mathrm{CaP}$ has not been clearly demonstrated. We present in vitro and in vivo data that the GRP autocrine loop is sufficient to establish androgen independence in $\mathrm{LNCaP}$ cells by inappropriate activation of the androgen receptor. We also show that GRP activates Src, Lyn, FAK and Etk tyrosine kinases, which confer motility and invasiveness to CaP. Our in vivo inhibitor study demonstrates that administration of Src inhibitor AZD0530 completely blocks tumor metastasis in the androgenindependent environment.

There are numerous reports on growth factors $(32)$, cytokines, chemokines $(2,4)$ and neuropeptides $(3,25)$ promoting androgen-independent growth of $\mathrm{LNCaP}$ cells. While the ligands inducing AR activation are different, many of them transmit signals through SFK $(3,4$, 25). In the present model, we focused on neuropeptides which are coupled to GPCRs and as we showed before, activate the tyrosine kinase complex Src/FAK/Etk (3). We hypothesized that induced expression of GRP in LNCaP cells may facilitate a more aggressive phenotype via 
autocrine stimulation. Our engineered LNCaP GRP cells demonstrated androgen- and anchorage -independent growth and superior migration compared to control LNCaP-Zeo cells, and the bombesin/GRP specific antibody 2A11 partially inhibited the increased growth and migration. This incomplete inhibition by 2A11 may be due to secretion of other neuropeptides such as neurotensin from the GRP clones (data not shown). These other factors also activate GPCRs, thus there is greater inhibition with GRP receptor inhibition compared to 2A11. Consistent with the in vitro properties, autocrine GRP activity supports androgen-independent tumorigenesis of LNCaP-GRP clones in castrated mice. IHC staining demonstrated nuclear localization of AR and PSA expression in tumor cells, supporting GRP stimulation of AR in the absence of testicular androgens, which is the sole source of androgen in mice. These observations build upon those reported by Burchardt and colleagues who demonstrated that androgen withdrawal of established in vivo LNCaP tumors resulted in enrichment of neuroendocrine cells (5). Herein we demonstrate that Src mediates the nuclear-translocation and target recruitment of AR induced by GRP, based on in vitro (ChIP assay) and in vivo (tumor IHC) analyses. A related report using a neuroendocrine mouse prostate allograft also showed neuroendocrine secretions were sufficient to support androgen-independent growth of LNCaP and PSA expression in vivo (33). These data together firmly establish the potential of neuropeptides secreted by neuroendocrine differentiated cells to induce androgen independence, and this process involves Src activation.

Elevated tyrosine phosphorylations, especially Src activation were shown in hormonerefractory prostate cancer xenografts derived from castrated animals (28). In this study, we showed that Src (and likewise, Lyn) is activated both in the free form as well as in the Src/FAK/Etk complex form. As expected, FAK and Etk are also activated as indicated by their heightened phosphorylation status. Impressively, AZD0530 treatment completely blocked these activations. The exact mechanism how bombesin/GRP activates AR to induce androgen 
independent growth of LNCaP is not fully understood. Although GRP has been reported to mediate MAPK and Src activation through epidermal growth factor receptor (EGFR) in some human malignancies (34), we observed no increased tyrosine phosphorylation of EGFR in LNCaP cells upon bombesin stimulation (data not shown). Despite reports implicating Src kinase in the development, growth, progression and metastasis of human cancers, only one report correlates elevated Src activation and AR phosphorylation to hormone-refractory $\mathrm{CaP}$ (28). This report elegantly showed that tyrosine residue Y534 of AR is the direct target of Src phosphorylation, which effectively translocates AR into the nucleus for gene transcription in the absence of androgen. Another report relates expression of a truncated c-kit tyrosine kinase, which is a strong activator of Src, to advanced stages of $\mathrm{CaP}$ (35), suggesting the importance of $\mathrm{Src}$ activity in $\mathrm{CaP}$ progression. Here we show that reversion of androgen-independent growth of GRP lines by knocking out Src with siRNA supports a significant role for Src in GRPmediated cell proliferation. It is speculated that modification of AR or its co-activators by phosphorylation (36) or acetylation (37) mimics the conformation change caused by androgen binding to activate AR in the absence of its cognate ligand. Src may potentially phosphorylate AR directly or through an intermediate molecule (28). Yet, since no tyrosine-phosphorylated AR was detected in bombesin-treated LNCaP cells (25), the exact mechanism how Src is involved still remains to be elucidated. In the ChIP assay, GRP mediated AR recruitment preferentially to the proximal ARE site in the PSA promoter, rather than to the enhancer ARE. This observation may reflect conformational modification of AR by Src or a downstream kinase, which facilitates AR activation by assembling a different co-activator complex to elicit gene transactivation in the absence of its natural ligand. Similarly, the reason why addition of R1881 to GRP clone did not increase the reporter activity further may be that GRP-activated AR is already in active conformation and may not be further stimulated by androgen. Our studies also 
revealed that post-translationally activated AR may be conformationally different from ligand bound AR, a finding supported by previous studies $(4,25)$. Further structural analysis will be required to substantiate this notion.

LNCaP cells are usually not very migratory, but overexpression of GRP under androgenfree conditions enhances LNCaP-GRP cell migration. Another reported mechanism is that bombesin activates RhoA and Rho-associated coiled-coil forming protein kinase to promote $\mathrm{CaP}$ cell migration and invasion (38). Since RhoA can be activated by Etk (39) which is activated by Src (40), our data are consistent with their findings. FAK phosphorylation in bombesinstimulated PC-3 cells is linked to cell motility and invasion (41). In collaboration with FAK, Etk is also involved in integrin signaling and promotes PC-3M migration (31). Knocking down Etk expression with its specific siRNA inhibits LNCaP cell proliferation $(29,42)$, and prostates from Etk transgenic mice exhibit pathological changes resembling human prostate intraepithelial neoplasia (29). Complexing of these three kinases results in synergistic activation and may transduce GRP modulated signaling in CaP cell proliferation, migration and survival.

Targeting the bombesin/GRP receptor for cancer therapy is undergoing early clinical trials (43). Other clinical trials have reported promising results using tyrosine kinase inhibitors in cancer therapy; for instances, imatinib (Gleevec, STI571) for chronic myelogenous leukemia and gastrointestinal stromal tumors $(44,45)$ and trastuzumab (Herceptin, Her-2 antibody) for breast cancer (46). Our approach suggests using a SFK inhibitor to target the activation of nonreceptor tyrosine kinases. Through inhibiting Src, AZD0530 prevents the Src-specific activation of FAK, AR and possibly Etk and effectively blocks tumor metastasis in our GRP autocrine model. Complex growth factors available in tumor microenvironments and the compensatory pathways involving cell proliferation downstream to Src may be factors why AZD0530 alone could not halt primary tumor growth. $\mathrm{IC}_{50}$ 's for inhibiting FAK, paxillin and $\mathrm{P} 130 \mathrm{Cas}$ 
responsible for migration were 4-64 fold lower than those for cyclin-D1 and c-Myc for proliferation (27). AZD0530 has been tested in tamoxifen-resistant breast cancer cells to suppress tumor cell migration through modulating FAK (47). Treating A549 lung carcinoma cells with AZD0530 results in down regulation of Id1 gene expression possibly through BMPSmad-Id pathway involved angiogenesis and metastasis (48). The other small molecule Src inhibitor Dasatinib (49), displays similar inhibitory mechanism as AZD0530 with more inhibition on metastasis than tumor growth in vivo (50). Lyn, a member of SFK, found to play a role in PC-3 tumor progression, was also inhibited by AZD0530 (data not shown).

In addition to neuropeptides, we have previously shown Src kinase activation as central to IL-8-induced androgen-independent prostate cell growth (4). Importantly, IL-8 is also a ligand for GPCRs. As such, inhibition of signaling transduction through Src kinase as a downstream target may block the oncogenic stimulation for more than one ligand. The specific mechanisms activating AR remain to be elucidated, but the pathways identified suggest Src kinase inhibition may prove useful in the treatment of androgen-independent $\mathrm{CaP}$.

\section{ACKNOWLEDGEMENTS}

We thank Dr. Cuttitta (NIH) for providing the monoclonal antibody to bombesin, 2A11, and Dr. Schally (Tulane University) for GRP receptor antagonists RC3095 and RC3940-II. The work is supported by NIH grant KO8-DK60748-01 (CPE), RO1-DK52659 (HJK), DOD PC060508 (HJK) and DOD grant PC040161 (CPE).

\section{Figure legends}

Figure 1. The model of an androgen-independent GRP expressing prostate cancer line, with evidence of enhanced proliferation and migration: A, Northern blot and RT-PCR assays verified expression of GRP gene into LNCaP GRP clones compared to the parental LNCaP / mocktransfected Zeo cells (negative controls) and DMS53 (positive control) cells. B, Quantitation of 
secreted GRP in CM collected from LNCaP, LNCaP-zeo, GRP1-1, GRP4-9, and small cell lung carcinoma DMS53 cells. C, Androgen-independent growth of GRP1-1 and 4-9 was targeted by inhibitors for GRP and its receptor. All inhibitors reduced the GRP cell growth in CS media with significance. $D$, Boyden chamber migration assay. Conditioned media $(\mathrm{CM})$ were collected from cells by overlaying SF media on sub-confluent plates for $48 \mathrm{hr}$ and the amount to use was normalized by the total protein concentration of each plate. CM from LNCaP-Zeo (ctlCM) or GRP (GRPCM) cells were used as the chemo-attractants. GRP-specific monoclonal antibody $2 \mathrm{~A} 11(1 \mu \mathrm{g} / \mathrm{ml})$ was introduced as the inhibitor. Bombesin $(100 \mathrm{nM})$ was the positive control. Migration assay was conducted as described in the Materials and Methods. Means of data from at least three independent experiments were plotted and bars represent standard error of the mean.

Figure 2. In vitro (soft agar assay) and in vivo (nude mice) tumorigenesis in androgen-deprived conditions: A, Soft agar assay was performed in CS medium as described in Materials and Methods. The experiment has been performed independently three times and the error bars represent standard error of the mean. B, Example of orthotopic implanted LNCaP-GRP tumor grown in a castrated nude mouse. Top: whole tumor after 4 months. Bottom: $\mathrm{H}$ and $\mathrm{E}$ staining showed LNCaP-GRP tumor on left side, mouse prostate stroma in the middle, and normal mouse prostate gland on the right. $C$, IHC staining of GRP ( $a$ and $b)$, AR ( $c$ and $d)$ and PSA ( $e$ and $f)$ in the tumor specimens: Slides on the left ( $a, c$ and $e$ ) showed most of the normal mouse prostate region; while on the right ( $b, d$ and $f$ ) showed predominately prostate tumors.

Figure 3. A, Soft agar assay of the re-cultured GRP-Pro xenograft: Soft agar assay was performed as described in the Materials and Methods. Treatments include monoclonal antibody to bombesin/GRP, 2A11 (1 $\mu \mathrm{g} / \mathrm{ml})$, anti-androgen bicalutamide (BIC, $5 \mu \mathrm{M})$, combination of 2A11 and BIC and synthetic androgen R1881 (1 nM). B, Transactivation assay: LNCaP-Zeo, 
GRP 4-9 and GRP-Pro cells were plated in CS medium and transfected with the PSA-Luc (630 bp) and pTK-RL. R1881 (1 nM) was added to some wells 24 hours post transfection and dualluciferase assay was conducted after another 24 hours. Means of triplicate experiments were plotted and bars represent standard error of the mean. C, Chromatin immunoprecipitation assay: AR binding to both the enhancer and proximal ARE in the PSA promoter was revealed through PCR analysis using ChIP assay coupled with amplification with primers described in the Materials and Methods. "E", "P”, and "I" designate for the upstream enhancer region, proximal ARE region, and the intervening region, respectively.

Figure 4. Immunofluorescent staining of AR in LNCaP-Zeo and GRP4-9 cells in response to AZD0530 treatment. AR localization in the nuclei of GRP4-9 cells under androgen-deprived conditions is inhibited by AZD0530. Numbers on the right represent the percentage of cells with AR nuclear localization.

Figure 5. A, Effect of AZD0530 on Src/FAK/Etk complex: Phosphorylation status of Src, Lyn and FAK kinases in LNCaP-zeo and GRP subclones was shown in the upper panel. Treatment of all cells with $1 \mu \mathrm{M}$ of AZD0530 for 2 hours diminishes kinase activations in all cells without affect the total protein levels. Association of Src/FAK/Etk complex was illustrated by coimmunoprecipitation with the anti-FAK antibody. Cell lysates from Zeo and GRP cells were immunoprecipitated with anti-FAK antibody and probed for p-Etk, p-FAK, total FAK p-Src and total Src antibodies. Numbers under the untreated samples represent the densitometric quantification for phosphorylation after normalized by the total protein loading. $B$, Knocking down Src with siSrc transfection impaired the androgen-independent growth of GRP4-9 and GRP-Pro cells in CS media. LNCaP-Zeo cells were used as the control for GRP cells and SC (scramble control) was used as the control for siSrc. Western blots validated the siSrc transfection. C, Effect of AZD0530 and siSrc transfection on migration: AZD0530 (500 nM) or 
knocking down Src kinase with siSrc inhibited GRP4-9 and GRP-Pro cell migration. SC

(scramble control) was used as the control for siSrc. The experiment has been performed independently at least three times and the error bars represent standard error of the mean.

Figure 6. In vivo inhibition study in SCID mice: $A$, The representative picture showed primary prostate tumor with lymph node metastasis in an animal from the control group. H\&E staining of the lymph node sample validates its prostate cancer origin. B, IHC staining of the control and AZD0530 treated tumor samples with anti-p-Src (Y419), anti-p-FAK (Y861) and anti-AR (PG21) antibodies. $C$, Means of PSA levels in sera, primary tumor weight and metastasis incidents were plotted between the control and AZD0530 treatment groups.

\section{REFERENCES}

1. Jemal A, Siegel R, Ward E, Murray T, Xu J, Thun MJ. Cancer statistics, 2007. CA: a cancer journal for clinicians 2007;57:43-66.

2. Culig Z, Steiner H, Bartsch G, Hobisch A. Interleukin-6 regulation of prostate cancer cell growth. Journal of cellular biochemistry 2005;95:497-505.

3. Lee LF, Guan J, Qiu Y, Kung HJ. Neuropeptide-induced androgen independence in prostate cancer cells: roles of nonreceptor tyrosine kinases Etk/Bmx, Src, and focal adhesion kinase. Mol Cell Biol 2001;21:8385-97.

4. Lee LF, Louie MC, Desai SJ, et al. Interleukin-8 confers androgen-independent growth and migration of LNCaP: differential effects of tyrosine kinases Src and FAK. Oncogene 2004;23:2197-205.

5. Burchardt T, Burchardt, M., Chen, M.W., Cao, Y., de la Taille, A., Shabsigh, A., Hayek, O., Dorai, T., Buttyan, R. Transdifferentiation of prostate cancer cells to a neuroendocrine cell phenotype in vitro and in vivo. $\mathrm{J}$ Urol 1999;162:1800-5.

6. Cox ME, Deeble PD, Lakhani S, Parsons SJ. Acquisition of neuroendocrine characteristics by prostate tumor cells is reversible: implications for prostate cancer progression. Cancer Research 1999;59:3821-30.

7. Vashchenko N, Abrahamsson PA. Neuroendocrine differentiation in prostate cancer: implications for new treatment modalities. Eur Urol 2005;47:147-55.

8. Cuttitta F, Carney DN, Mulshine J, et al. Bombesin-like peptides can function as autocrine growth factors in human small-cell lung cancer. Nature 1985;316:823-6.

9. Nagata A, Ito M, Iwata N, et al. G protein-coupled cholecystokinin-B/gastrin receptors are responsible for physiological cell growth of the stomach mucosa in vivo. Proc Natl Acad Sci U S A 1996;93:11825-30.

10. Abrahamsson PA. Neuroendocrine cells in tumour growth of the prostate. Endocr Relat Cancer 1999;6:503-19.

11. Rozengurt E. Neuropeptides as growth factors for normal and cancerous cells. Trends Endocrinol Metab 2002;13:128-34.

12. Kim S, Hu W, Kelly DR, Hellmich MR, Evers BM, Chung DH. Gastrin-releasing peptide is a growth factor for human neuroblastomas. Ann Surg 2002;235:621-9; discussion 9-30. 
13. Guha S, Lunn JA, Santiskulvong C, Rozengurt E. Neurotensin stimulates protein kinase Cdependent mitogenic signaling in human pancreatic carcinoma cell line PANC-1. Cancer Res 2003;63:2379-

87.

14. Aprikian AG, Han K, Guy L, Landry F, Begin LR, Chevalier S. Neuroendocrine differentiation and the bombesin/gastrin-releasing peptide family of neuropeptides in the progression of human prostate cancer. Prostate Supplement 1998;8:52-61.

15. Festuccia C, Guerra F, S DA, Giunciuglio D, Albini A, Bologna M. In vitro regulation of pericellular proteolysis in prostatic tumor cells treated with bombesin. International Journal of Cancer 1998;75:418-31.

16. Wu JT, M.E. Astill, G.H. Liu, and R.A. Stephenson. Serum chromogranin A: early detection of hormonal resistance in prostate cancer patients. J Clin Lab Anal 1998;12:20-5.

17. Bartholdi MF, Wu JM, Pu H, Troncoso P, Eden PA, Feldman RI. In situ hybridization for gastrinreleasing peptide receptor (GRP receptor) expression in prostatic carcinoma. Int J Cancer 1998;79:82-90. 18. Markwalder R, Reubi JC. Gastrin-releasing peptide receptors in the human prostate: relation to neoplastic transformation. Cancer Res 1999;59:1152-9.

19. Luttrell LM, Daaka Y, Lefkowitz RJ. Regulation of tyrosine kinase cascades by G-protein-coupled receptors. Curr Opin Cell Biol 1999;11:177-83.

20. Aprikian AG, Han K, Chevalier S, Bazinet M, Viallet J. Bombesin specifically induces intracellular calcium mobilization via gastrin-releasing peptide receptors in human prostate cancer cells. Journal of Molecular Endocrinology 1996;16:297-306.

21. Han K, J. Viallet, S. Chevalier, W. Zheng, M. Bazinet, and A.G. Aprikian. Characterization of intracellular calcium mobilization by bombesin-related neuropeptides in PC-3 human prostate cancer cells. Prostate 1997;31:53-60.

22. Siegfried JM, Guentert PJ, Gaither AL. Effects of bombesin and gastrin-releasing peptide on human bronchial epithelial cells from a series of donors: individual variation and modulation by bombesin analogs. Anat Rec 1993;236:241-7.

23. Cai RZ, Reile H, Armatis P, Schally AV. Potent bombesin antagonists with C-terminal Leu-psi(CH2N)-Tac-NH2 or its derivatives. Proc Natl Acad Sci U S A 1994;91:12664-8.

24. Sausville EA, Lebacq-Verheyden AM, Spindel ER, Cuttitta F, Gazdar AF, Battey JF. Expression of the gastrin-releasing peptide gene in human small cell lung cancer. Evidence for alternative processing resulting in three distinct mRNAs. J Biol Chem 1986;261:2451-7.

25. Desai SJ, Ma AH, Tepper CG, Chen HW, Kung HJ. Inappropriate activation of the androgen receptor by nonsteroids: involvement of the Src kinase pathway and its therapeutic implications. Cancer Res 2006;66:10449-59.

26. Louie MC, Yang HQ, Ma AH, et al. Androgen-induced recruitment of RNA polymerase II to a nuclear receptor-p160 coactivator complex. Proc Natl Acad Sci U S A 2003;100:2226-30.

27. Chang YM, Bai L, Liu S, Yang JC, Kung HJ, Evans CP. Src family kinase oncogenic potential and pathways in prostate cancer as revealed by AZD0530. Oncogene 2008.

28. Guo Z, Dai B, Jiang T, et al. Regulation of androgen receptor activity by tyrosine phosphorylation. Cancer Cell 2006;10:309-19.

29. Dai B, Kim O, Xie Y, et al. Tyrosine kinase Etk/BMX is up-regulated in human prostate cancer and its overexpression induces prostate intraepithelial neoplasia in mouse. Cancer Res 2006;66:8058-64.

30. Mitra SK, Hanson DA, Schlaepfer DD. Focal adhesion kinase: in command and control of cell motility. Nature reviews 2005;6:56-68.

31. Chen R, Kim O, Li M, et al. Regulation of the PH-domain-containing tyrosine kinase Etk by focal adhesion kinase through the FERM domain. Nat Cell Biol 2001;3:439-44.

32. Culig Z, Hobisch A, Cronauer MV, et al. Androgen receptor activation in prostatic tumor cell lines by insulin-like growth factor-I, keratinocyte growth factor, and epidermal growth factor. Cancer Res 1994;54:5474-8.

33. Jin RJ, Wang Y, Masumori N, et al. NE-10 neuroendocrine cancer promotes the LNCaP xenograft growth in castrated mice. Cancer Res 2004;64:5489-95.

34. Thomas SM, Grandis JR, Wentzel AL, Gooding WE, Lui VW, Siegfried JM. Gastrin-releasing peptide receptor mediates activation of the epidermal growth factor receptor in lung cancer cells. Neoplasia 2005;7:426-31.

35. Paronetto MP, Farini D, Sammarco I, et al. Expression of a truncated form of the c-Kit tyrosine kinase receptor and activation of Src kinase in human prostatic cancer. Am J Pathol 2004;164:1243-51. 36. Gioeli D, Ficarro SB, Kwiek JJ, et al. Androgen receptor phosphorylation. Regulation and identification of the phosphorylation sites. J Biol Chem 2002;277:29304-14. 
37. Gong J, Zhu J, Goodman OB, Jr., et al. Activation of p300 histone acetyltransferase activity and acetylation of the androgen receptor by bombesin in prostate cancer cells. Oncogene 2006;25:2011-21.

38. Zheng $\mathbf{R}$, Iwase A, Shen $\mathbf{R}$, et al. Neuropeptide-stimulated cell migration in prostate cancer cells is mediated by RhoA kinase signaling and inhibited by neutral endopeptidase. Oncogene 2006;25:5942-52.

39. Mao J, Xie W, Yuan H, Simon MI, Mano H, Wu D. Tec/Bmx non-receptor tyrosine kinases are involved in regulation of Rho and serum response factor by Galpha12/13. The EMBO journal 1998;17:563846.

40. Tsai YT, Su YH, Fang SS, et al. Etk, a Btk family tyrosine kinase, mediates cellular transformation by linking Src to STAT3 activation. Mol Cell Biol 2000;20:2043-54.

41. Aprikian AG, Tremblay L, Han K, Chevalier S. Bombesin stimulates the motility of human prostatecarcinoma cells through tyrosine phosphorylation of focal adhesion kinase and of integrin-associated proteins. Int J Cancer 1997;72:498-504.

42. Jiang X, Borgesi RA, McKnight NC, Kaur R, Carpenter CL, Balk SP. Activation of Nonreceptor Tyrosine Kinase Bmx/Etk Mediated by Phosphoinositide 3-Kinase, Epidermal Growth Factor Receptor, and ErbB3 in Prostate Cancer Cells. J Biol Chem 2007;282:32689-98.

43. Zhou J, Chen J, Mokotoff M, Ball ED. Targeting gastrin-releasing peptide receptors for cancer treatment. Anticancer Drugs 2004;15:921-7.

44. Druker BJ, Talpaz M, Resta DJ, et al. Efficacy and safety of a specific inhibitor of the BCR-ABL tyrosine kinase in chronic myeloid leukemia. N Engl J Med 2001;344:1031-7.

45. Verweij J, van Oosterom A, Blay JY, et al. Imatinib mesylate (STI-571 Glivec, Gleevec) is an active agent for gastrointestinal stromal tumours, but does not yield responses in other soft-tissue sarcomas that are unselected for a molecular target. Results from an EORTC Soft Tissue and Bone Sarcoma Group phase II study. Eur J Cancer 2003;39:2006-11.

46. Slamon DJ, Leyland-Jones B, Shak S, et al. Use of chemotherapy plus a monoclonal antibody against HER2 for metastatic breast cancer that overexpresses HER2. N Engl J Med 2001;344:783-92.

47. Hiscox S, Jordan NJ, Morgan L, Green TP, Nicholson RI. Src kinase promotes adhesion-independent activation of FAK and enhances cellular migration in tamoxifen-resistant breast cancer cells. Clinical \& experimental metastasis 2007;24:157-67.

48. Gautschi O, Tepper CG, Purnell PR, et al. Regulation of Id1 expression by SRC: implications for targeting of the bone morphogenetic protein pathway in cancer. Cancer Res 2008;68:2250-8.

49. Nam S, Kim D, Cheng JQ, et al. Action of the Src family kinase inhibitor, dasatinib (BMS-354825), on human prostate cancer cells. Cancer Res 2005;65:9185-9.

50. Park SI, Zhang J, Phillips KA, et al. Targeting SRC family kinases inhibits growth and lymph node metastases of prostate cancer in an orthotopic nude mouse model. Cancer Res 2008;68:3323-33. 